\title{
Soil characterization, classification, and biomass accumulation in the Otter Creek Wilderness
}

Jamie Schnably

West Virginia University

Follow this and additional works at: https://researchrepository.wvu.edu/etd

\section{Recommended Citation}

Schnably, Jamie, "Soil characterization, classification, and biomass accumulation in the Otter Creek Wilderness" (2003). Graduate Theses, Dissertations, and Problem Reports. 1800.

https://researchrepository.wvu.edu/etd/1800

This Thesis is protected by copyright and/or related rights. It has been brought to you by the The Research Repository @ WVU with permission from the rights-holder(s). You are free to use this Thesis in any way that is permitted by the copyright and related rights legislation that applies to your use. For other uses you must obtain permission from the rights-holder(s) directly, unless additional rights are indicated by a Creative Commons license in the record and/ or on the work itself. This Thesis has been accepted for inclusion in WVU Graduate Theses, Dissertations, and Problem Reports collection by an authorized administrator of The Research Repository @ WVU. For more information, please contact researchrepository@mail.wvu.edu. 


\title{
Soil Characterization, Classification, and Biomass Accumulation in the Otter Creek Wilderness
}

\author{
Jamie Schnably
}

Thesis submitted to

The Davis College of Agriculture, Forestry, and Consumer Sciences at West Virginia University

In partial fulfillment of the requirements for the degree of

\author{
Master of Science \\ In \\ Plant and Soil Sciences
}

John C. Sencindiver, Ph. D., Chair

Louis McDonald, Ph. D.

Ray Hicks, Ph. D.

Stephen Carpenter, M.S.

Division of Plant and Soil Sciences

Morgantown, West Virginia

2003 


\begin{abstract}
Soil Characterization, Classification, and Biomass Accumulation in the Otter Creek Wilderness
\end{abstract}

\author{
Jamie Schnably
}

This study evaluated soils of the Otter Creek Wilderness in the Monongahela National Forest. Thirteen sites were sampled and analyzed according to landscape position: three terrace soils (T), four ridgetop soils (R), three sideslope soils with argillic horizons (SSA), and three sideslope soils with cambic horizons (SSC). AT each site, one pedon was described and sampled, and biomass data were collected. Standard chemical and physical properties, clay mineralogy, extractable sulfate and sulfated adsorption capacity were analyzed. The SSA soils had the highest $\mathrm{pH}$, the most diverse vegetation, and the highest base saturation. These soils had a low ridk for acid toxicity to fine roots and mychorrizal fungi. Also, these soils has the highest Ca:Al ratio. In addition, SSA soils had the greatest capacity to adsorb additional sulfate. The most adverse soil conditions were found on the SSC and T sites, with R soils exhibiting moderate conditions. 


\section{ACKNOWLEDGEMENTS}

This thesis project is a conglomeration of many people's efforts. I would first like to extend my greatest appreciation to a man, who without his wisdom, patience, insight, and encouragement, this thesis would not be possible: my mentor, Dr. John C. Sencindiver. Thank you, thank you and thank you. These words cannot be uttered enough for all that you have given and shared with me.

Next (and perhaps they should have been mentioned first; it was a tough decision), I would like to of course thank my parents. They were always in my ear nagging, I mean "encouraging" me from start to finish on this project (you two know I am just kidding). Seriously, they have been encouraging me to explore whatever path I wanted to take my entire life, as long as it meant getting a good education and I think I have adequately met this request. They have been a rock for me on many different levels, and for this and all of the support, I thank you. Their pride is a wonderful gift.

To all in this wonderful learning establishment that we fondly call WVU that have participated in some way to making this thesis a quality document I offer my gratitude. This includes (but is not limited to): all professors in the agronomy department for their help and wisdom, to Joan Wright for all of her hours spent on various machines running my gazillion samples, to Brian Cooley for aid in the lab, to all graduate students who have also given me there knowledge and experience, and to Michael Stragger who has given his time on multiple occasions to assist me on various GIS problems.

Now to thank the government (Yes, they get thanked too. The government always finds their way in). Without the aid of the Natural Resources Conservation Service and the United States Forest Service this project would have not existed. I would like to sincerely thank the USFS for providing me the means to conduct this research, and particularly, Stephanie Connolly for her generosity, her wisdom, and her time.

Stephanie, you have been a role model and an inspiration. Thank you NRCS for all of your help with the sampling and describing of my soils, particularly Tony Jenkins who has lent me his back and his brain on many occasions. Tony, you truly are a soils genius.

I would like to thank my committee members, Dr. McDonald, Dr. Hicks, and

Steve Carpenter. Each one of you has played an intricate role in this project and has assisted me in conducting my research along the way.

Finally, I would like to thank all others that have been close to me and supported me through this endeavor. To all of my friends who have made me laugh and have been there for me in times of tears, thank you. To my office-mate Rosa Lee for dealing with a constant clutter of papers, journals, and sometimes pure insanity and for always lending an ear, thank you. To my two sisters who, no matter what, could always put a smile on my face, thanks. And to mi Miguel for your understanding, support, encouragement, for all of the smiles, for putting up with my crazy hours, for the long and needed hugs, for always being there and for just being you, thank you. 
TABLE OF CONTENTS

$\underline{\text { Page }}$
ABSTRACT
ACKNOWLEDGEMENTS
LIST OF TABLES
LIST OF FIGURES
INTRODUCTION

LITERATURE REVIEW 3

General Properties of Forest Soils in Appalachia 3

$\begin{array}{lr}\text { Sulfate Adsorption Capacity } & 14\end{array}$

Biomass and Soil Productivity 19

METHODS AND MATERIALS 22

Site Description and Location of Soils $\quad 22$

Field Procedures $\quad 23$

Laboratory Analyses $\quad 25$

Biomass Accumulation $\quad 30$

Statistical Analysis $\quad 33$

RESULTS AND DISCUSSION

Morphology, Genesis, and Field Observations $\quad 33$

Physical, Chemical, and Mineralogical Properties 39

$\begin{array}{ll}\text { Classification } & 54\end{array}$

Extractable Sulfate and Sulfate Adsorption Potential 61

Biomass Accumulation $\quad 65$

SUMMARY AND CONCLUSIONS

$\begin{array}{ll}\text { General Observations } & 67\end{array}$

$\begin{array}{ll}\text { Practical Applications } & 68\end{array}$

REFERENCES

\section{APPENDICES}

$\begin{array}{ll}\text { Soil Profile Descriptions } & 77\end{array}$

Soil physical data for each pedon $\quad 91$

$\begin{array}{lr}\text { Soil chemical data for each pedon } & 105\end{array}$

Biomass and productivity data for each pedon 132

$\begin{array}{ll}\text { Clay mineralogy data for each pedon } & 136\end{array}$ 


\section{LIST OF TABLES}

$\underline{\text { Table }}$

1. Criteria used for biomass data collection at each pedon location

2. Average organic horizon thickness, mineral solum thickness, slope, and drainage class of Otter Creek soils

3. Clay percentages of soil horizons across landscape positions

4. Average percent carbon for horizons across landscape positions for soils in the Otter Creek Wilderness

5. Carbon stocks for whole soils

6. Cation exchange capacity and ECEC of horizons across landscape positions

7. Percent base saturation of the ECEC of the $A+E$ and $B$ horizons of soils across various landscape positions

8. Average percentages and ranges of clay species found in Otter Creek soils with respect to geology

9. Soil Classifications

10. Biomass density of trees in Otter Creek with respect to landscape position

11. Average stand age, biomass and productivity for soils in the Otter Creek Wilderness across various landscape positions

12. Physical data for pedon T1 92

13. Physical data for pedon T2 93

14. Physical data for pedon T3 94

15. Physical data for pedon R1 95

16. Physical data for pedon R2 96

17. Physical data for pedon R3 97

18. Physical data for pedon R4 98 
$\underline{\text { Table }}$

19. Physical data for pedon SSC1

20. Physical data for pedon SSC2

100

21. Physical data for pedon SSC3

101

22. Physical data for pedon SSA1

102

23. Physical data for pedon SSA2

103

24. Physical data for pedon SSA3

104

25. Chemical data for pedon $\mathrm{T} 1$

106

26. Chemical data for pedon $\mathrm{T} 2$

108

27. Chemical data for pedon T3

110

28. Chemical data for pedon $\mathrm{R} 1$

112

29. Chemical data for pedon R2

114

30. Chemical data for pedon R3

116

31. Chemical data for pedon R4

118

32. Chemical data for pedon SSC1

120

33. Chemical data for pedon SSC2

122

34. Chemical data for pedon SSC3

124

35. Chemical data for pedon SSA1

126

36. Chemical data for pedon SSA2

128

37. Chemical data for pedon SSA3

130

38. Biomass data for each pedon

133

39. Individual sawtimber biomass for each species at each site

134

40. Stand ages and productivity values for each pedon

41. Clay mineralogy for each pedon

137 


\section{LIST OF FIGURES}

Figure

$\underline{\text { Page }}$

1. Otter Creek Wilderness in Tucker and Randolph Counties, West Virginia

2. Geology of the Otter Creek Wilderness with pedon sites located

3. Average bulk density of Otter Creek soils on different landscape postions

4. Average $\mathrm{pH}$ values of soil horizons in Otter Creek across various landscapes

5. Average exchangeable calcium concentrations of forest soil horizons in the Otter Creek Wilderness

6. Extractable aluminum of forest soil horizons in the Otter Creek Wilderness across various landscape positions

7. Ca:Al molar ratio of Otter Creek soils spanning different landscape positions

8. Cation exchange capacity (via summation) of soils in the Otter Creek Wilderness

9. Average percent base saturation of horizons for Otter Creek soils across different landscape positions

10. Index of sulfate adsorption potential for soils in the Otter Creek Wilderness

11. Extractable sulfate of soil horizons for various landscape positions in the Otter Creek Wilderness

12. Sulfate adsorption potential of soils on various landscape positions in the Otter Creek Wilderness 


\section{INTRODUCTION}

Otter Creek Wilderness covers part of Tucker and Randolph Counties in West

Virginia (Figure 1) and is found in a bowl formed by Shavers Mountain and McGowan Mountain. Many of the streams in this area drain into Otter Creek and then to the Dry Fork River. Vegetation consists of second-growth timber, rhododendron (Rhododendron maximum), and a variety of mosses. Elevation ranges from 550 meters at the mouth of Otter Creek to 1190 meters on McGowan Mountain.

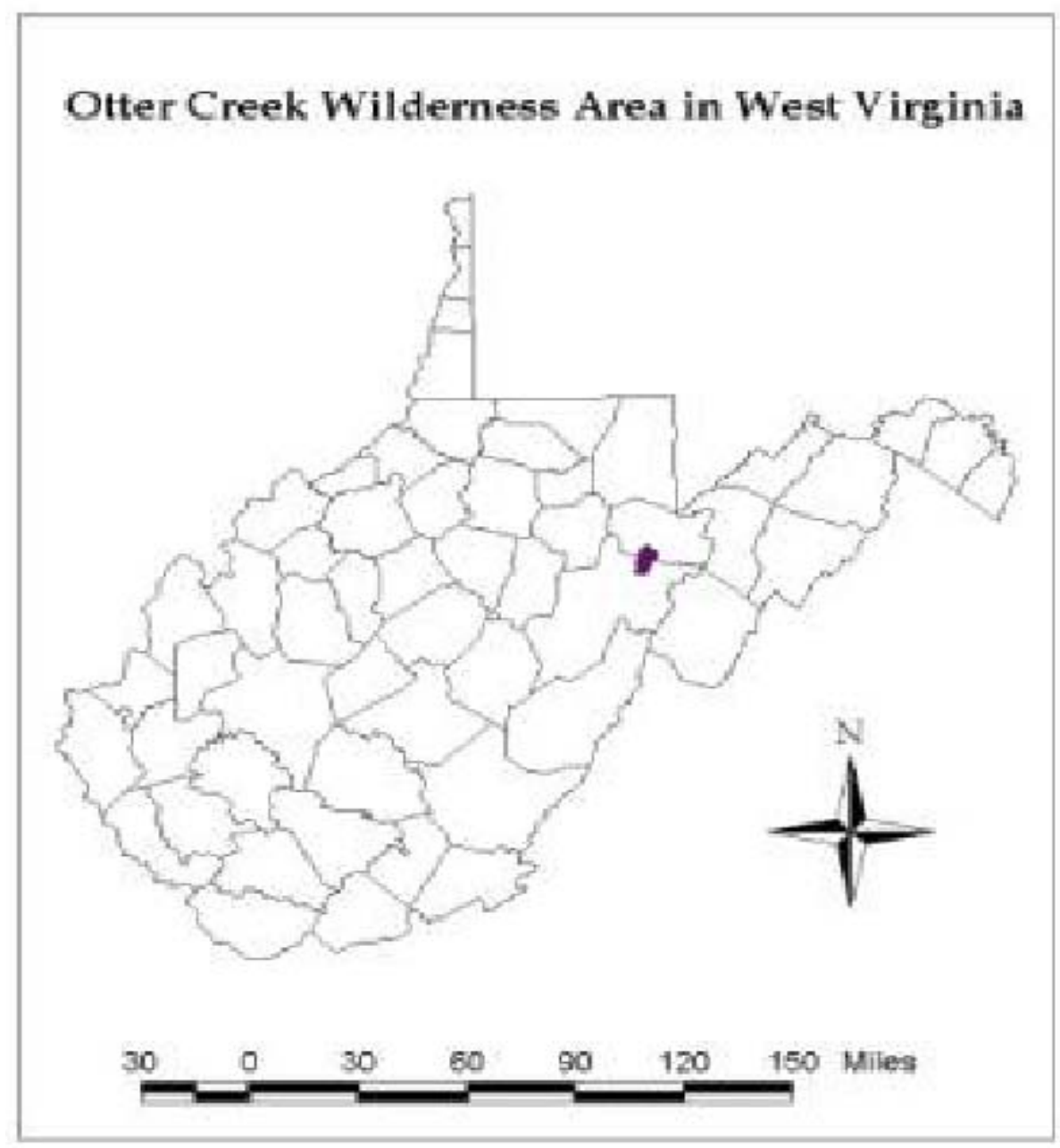

Figure 1. Otter Creek Wilderness in Tucker and Randolph Counties, West Virginia 
Most of Otter Creek was obtained by the U.S. government in 1917 and was utilized predominately as a recreational area (Anonymous, 2001). Prior to this date, the area was logged by the Otter Creek Boom and Lumber Company from 1897 to 1914, and several areas also were homesteaded. When the lumbering operations ceased, the native trees came back naturally, with only some Norway spruce (Picea abies) planted on top of Shavers Mountain in the 1920's. More logging was done from 1968 to 1972 as the second-growth timber started to reach merchantable size. About this time, some persons began working to get the Otter Creek region set aside as a wilderness area. In 1975, the area was designated as wilderness by the Eastern Wilderness Act, passed by Congress that same year (Anonymous, 2001).

Researching and understanding forest soil characteristics and properties are essential to the long-term health and productivity of forested areas. Within the continental US, the hardwood forests of the east constitute the largest forest type (Adams et al., 2000) and are an important resource for millions of people, economically and for recreation. In depth evaluations of soil physical, chemical, mineralogical, and biomass properties gives foresters and others a greater understanding of the processes occurring in these forested environments and allows for better management practices.

This project was funded by the United States Forest Service (USFS) to update the characterization, classification, and mapping of soils in the Otter Creek Wilderness. The USFS employed the aid of the Natural Resources Conservation Service (NRCS) in conjunction with West Virginia University (WVU) to help meet their goals. The main interest of the USFS was to use the data generated from the soils of the Otter Creek Wilderness in air quality modeling. The objectives of this research were to 
(1) characterize and classify major (previously unstudied) soils of the wilderness, and

(2) to evaluate biomass accumulation on the soils in the Otter Creek Wilderness.

\section{LITERATURE REVIEW}

\section{General Properties of Forest Soils in Appalachia}

\section{Soil Temperature}

Mean annual soil temperature (MAST) is a criterion used to classify soils at the family level (Soil Survey Staff, 1999). There are various ways to obtain this value. In the United States, an approximate estimate of MAST can be derived by adding $1{ }^{\circ} \mathrm{C}$ to the mean annual air temperature, but to obtain direct, more accurate measurements of MAST, once-a-month measurements of temperature at a depth of $50 \mathrm{~cm}$ below the soil surface is recommended (Buol et al., 1997).

One recent issue of interest in West Virginia and other areas of Appalachia is whether or not there are frigid soils in this region, and if so, at what elevations do they begin. A soil with a frigid soil temperature regime has a MAST of less than $8^{\circ} \mathrm{C}$, whereas a mesic soil temperature regime has a MAST between 8 and $15^{\circ} \mathrm{C}$ (Soil Survey Staff, 1999). In a study by Carter and Ciolkosz (1980), it was determined that there are parts of West Virginia that do indeed have frigid soils. They based this finding on a prediction 
equation that was derived from seasonal readings at a $50 \mathrm{~cm}$ depth. The equation was dependent on elevation and latitude of the pedon site and was as follows:

$\mathrm{Y}=11.7-0.0061 \mathrm{X}_{1}-0.0034 \mathrm{X}_{2}$,

where relative latitude (distance from the equator in $\mathrm{km})=\mathrm{X}_{1}$, elevation $(\mathrm{m})=\mathrm{X}_{2}$, and $\mathrm{Y}$ $=$ MAST . Using this equation, the mesic-frigid boundary was found to be $1,088+/-26 \mathrm{~m}$ at Davis, WV.

A similar study was conducted more recently where the authors focused on north facing aspects in Pocahontas and Greenbrier Counties, West Virginia (Mount and Paetzold, 2002). They formed an equation to determine the mesic/frigid break. This equation also used latitude and elevation as the determining criteria and was as follows:

$\mathrm{Y}=46.204504-0.0023030202 \mathrm{X}$

where $\mathrm{Y}=$ latitude in decimal degrees and $\mathrm{X}=$ elevation in feet. This equation produced a linear relationship relating latitude to elevation. If soil sites were above the line, they were considered frigid and if they fell below the linear relationship they were deemed mesic. The break for soils at $39^{\circ}$ latitude was approximately $969 \mathrm{~m}$.

When comparing the two studies, the data generated from Mount and Paetzold (2002) indicated that frigid soils occurred at a slightly lower elevation than those from the Carter and Coilkosz (1980) report. This was probably due to the fact that the Mount and Paetzold (2002) study focused on north facing slopes where temperatures are generally 
lower when compared to slopes with other aspects. For the most part, however, the two studies basically agreed on the dividing line between frigid and mesic soil temperature regimes.

\section{Soil Organic Matter, Humus and Carbon}

Organic matter $(\mathrm{OM})$ is the nutrient rich media that accumulates on the forest floor, and in which the forest grows. It is an energy source for soil organisms which, through their activity and interactions with mineral matter, impart the structure to soil that affects its stability and its capacity to provide water, air, and nutrients to plant roots (Van Cleve and Powers, 1995). Soil organic matter (SOM) is a key parameter of soil quality and plays a role in aggregate stability, porosity, and the release and availability of soil nutrients (Schoenholtz et al., 2000). It is composed of living plant and animal tissue, detrital remains from these sources, exudates from plant root systems, products of microbial synthesis and leachates from above- and belowground organic sources (Van Cleve and Powers, 1995). The prolonged existence of mature forests leads to nutrient cycling processes that are near steady state, with hardly any natural disturbance from year to year, and an intact litter layer and SOM content that determine many of the physical, chemical and biological properties of the forest soil (McColl and Gressel, 1995).

This organic layer is a major source of humus in the mineral soil. Humus is composed of the recalcitrant products of decomposition and is chemically stabilized (Prescott et al., 2000). Compared to the original plant material, humus is low in carbohydrates, high in large polyphenolic molecules (lignin component), and high in N. However, most of the $\mathrm{N}$ is bound in complex molecules of undetermined composition, 
and can be considered immobilized and essentially unavailable to plants and most microbes (Prescott et al., 2000). In acid forest soils, the humus fraction accounts for much of the soils' cation exchange capacity, as well as, aiding in soil structure development (Brady and Weil, 1999). Conversion of SOM to humus results in a distribution of very different kinds and qualities of soil organic carbon (SOC) throughout a pedon. Jenkins (2001) found that SOC generally decreased exponentially with depth with the average SOC stocks ranging from 11.3 to $18.8 \mathrm{~kg} \mathrm{~m}^{-2}$ for the West Virginia soils of his study.

One important aspect when examining the quality of a forested area is that although organic matter is undoubtedly beneficial to the system, one must consider that the substrate is at different levels of decomposition, and therefore, is at varying chemical and physical states, which in turn greatly affects the nutrient availability of the material. For example, Berg (2000) stated that in fresh litter, there may be a lack of macronutrients, such as $\mathrm{N}, \mathrm{P}$, and $\mathrm{S}$ thus limiting the decomposition rates of certain components, such as celluloses, and the rates may be positively related to, for example, the concentration of $\mathrm{N}$. Berg further explained that with the disappearance of celluloses, the concentration of the recalcitrant compound, lignin, increases and the effects of $\mathrm{N}$ concentration of decomposition rates change completely. Another study demonstrated that while humus is a substantial proportion of nutrient capital of a site, is critical to long-term site fertility, and aids in buffering the site against disturbances that might lead to nutrient depletion, it is also viewed as a nutrient sink that essentially competes with the trees for the growth limiting resource (Prescott et al., 2000). Prescott et al. (2000) stated that this is especially true in the case of surface accumulations of agrading forests, where the progressive 
immobilization of nutrients into humus may over time deplete the supply of available nutrients and reduce site productivity. These considerations need to be taken into account when attempting to manage a forested area.

One major characteristic of $\mathrm{OM}$ is its high concentration of $\mathrm{C}$ (compared to mineral soils). Forests dominate the terrestrial biosphere's $\mathrm{C}$ cycle, but many aspects of this cycle remain unresolved (Richter et al., 1995). Carbon, in forested situations, is found in living vegetation, in forest floor or the litter layer, and within the mineral soil. Because $\mathrm{C}$ storage is a net result of the processes of decomposition and primary production, controls of those processes, such as climate and soil properties, influence $\mathrm{C}$ storage (Grigal and Ohmann, 1992). The decay and storage of plant and animal remains in soil are basic biological processes and are fundamental parts of the $\mathrm{C}$ cycle. In the forest soil environment, respiration results in a release of $\mathrm{CO}_{2}$ through roots and mycorrhizal fungi, from heterotrophs that utilize root exudates, and from heterotrophic catabolism of other SOM. During this process, $\mathrm{C}$ is recirculated to the atmosphere as carbon dioxide $\left(\mathrm{CO}_{2}\right)$ through respiration, and nitrogen $(\mathrm{N})$ is made available as ammonium $\left(\mathrm{NH}_{4}{ }^{+}\right)$and nitrate $\left(\mathrm{NO}_{3}{ }^{-}\right)$. Other related elements, mainly phosphorus $(\mathrm{P})$, sulfur (S), and micronutrients such as iron $(\mathrm{Fe})$, manganese $(\mathrm{Mn})$, copper $(\mathrm{Cu})$, boron $(\mathrm{B})$, molybdenum (Mo), and zinc (Zn), occur in forms essential for higher plants. 


\section{Bulk Density}

Bulk density ( $\mathrm{Db})$ affects many physical aspects of soil including pore space, gas and water relations, infiltration rate, and rooting depth. Average bulk density of mineral soils ranges from 1.1 to $1.9 \mathrm{Mg} \mathrm{m}^{-3}$ with organic layers being considerably lower (Marshall et al., 1996). In an Appalachian forest, Jenkins found Db varying from $0.1 \mathrm{Mg}$ $\mathrm{m}^{-3}$ in the $\mathrm{O}$ horizons to $2.06 \mathrm{Mg} \mathrm{m}^{-3}$ in the mineral horizons. Bulk density typically increases with depth of the soil pedon due to increasing overburden and decreasing disturbance (Marshall et al., 1996). Soil compaction will increase Db of a soil (Marshall et al., 1996), and this can be a detrimental effect of harvesting forests when using ground based logging equipment (McNabb et al., 2001). Compaction, hence elevating bulk density, can hinder productivity by increasing physiological stress in the seedling or tree, or in its competition with other vegetation (McNabb et al., 2001).

\section{Soil pH}

Soil $\mathrm{pH}$ is an important property of soils and impacts many soil processes. This property influences nutrient availability. It affects the chemical form, adsorption, and precipitation of these nutrients. In general, most forest soils are very acidic with soils under coniferous vegetation having a lower $\mathrm{pH}$ than soils forming under deciduous species (Ste-Marie and Pare, 1999). These soils become acidic through natural processes, such as mineral weathering, nitrification, and organic acid production, in addition to acidification through anthropogenic processes (i.e. acidic deposition). In fact, changing air quality has become a potential threat to the eastern hardwood forest ecosystem by altering soil acidity, and in turn, the nutrient balance of the soil (Adams et al., 2000). 
Low $\mathrm{pH}$ soils have low base saturation and cation depletion associated with leaching and high aluminum concentrations, which can lead to aluminum toxicity in plants and other nutrient imbalances.

\section{Cation Exchange Capacity and Exchangeable Base Cation Nutrients}

Cation exchange sites in soil are either mineral (e.g., clays) or organic. This property is of concern because soils with low CEC values have a low buffering capacity and are susceptible to acidification and base cation leaching. Adams et al. (2000) rated soils as sensitive if they were poorly buffered with CEC values less than $15 \mathrm{cmol}_{\mathrm{c}} / \mathrm{kg}$, had moderate base saturation, and had a pH of less than 4.5. Spratt (1998) also confirmed that the principal mechanism for nutrient cation leaching in soils subjected to high levels of acidic precipitation was the exchange of nutrient cations, such as $\mathrm{K}^{+}, \mathrm{Ca}^{+2}$, and $\mathrm{Mg}^{+2}$, for $\mathrm{H}^{+}$associated with $\mathrm{SO}_{4}^{-2}$ from the precipitation. Such cations are essential to longterm sustainability of forest ecosystems. In a forest quality report, McLaughlin and Percy (1999) noted that tree response and soil sensitivity to acidic deposition were closely related to soil supply capacity for basic cations. This sensitivity was particularly apparent in the northern Appalachians, where nutrient deficiencies of $\mathrm{K}^{+}$and $\mathrm{Mg}^{+2}$ were initially associated with sugar maple decline. The relationship between the decline and the soil sensitivity was supported by a response to $\mathrm{K}^{+}, \mathrm{Mg}^{+2}$, and $\mathrm{Ca}^{+2}$ fertilizer, which improved foliar nutrient status, growth rates, and tree vigor in the declining maples. In addition, Federer et al. (1989) concluded that long term depletion of base cations from both foliage and soils in the eastern U.S. has led to accelerated depletion of exchangeable cations from 
mixed hardwood forested watersheds. Trettin et al. (1999) noted that deep rooting of trees was a major factor controlling cation uptake in mature forests. Therefore, it is often necessary to examine the pedon to depths greater than 50 or even $100 \mathrm{~cm}$, the typical sampling depths. This was supported by the fact that although the upper $60 \mathrm{~cm}$ of the forest soils in their study showed cation losses, productivity was sustained, supposedly by deep soil pools.

\section{Calcium and Aluminum}

Calcium is essential to forest health and productivity, having a direct and indirect role in the allocation of resources related to defense and repair mechanisms in plants as well as affecting respiratory metabolism and transpiration rate (McLaughilin and Percy, 1999). Availability of calcium is important, especially in developing plants, because it is crucial in the structure and permeability of cell membranes, is essential for cell elongation and division, aids in the regulation of cation uptake, and is interrelated with $\mathrm{N}$ metabolism due to the enhancement of nitrate uptake (Halvin et al., 1999).

The natural acidifying processes of forest soils compounded with acidic deposition can reduce the availability of $\mathrm{Ca}^{+2}$ and create $\mathrm{Ca}^{+2}$ deficiencies, which can hinder productivity. When $\mathrm{Ca}^{+2}$ is leached out of the soil system due to a decline in $\mathrm{pH}$, $\mathrm{Al}^{+3}$ increases, which can cause $\mathrm{Al}^{+3}$ toxicity and compound productivity threats posed by soil nutrient deficiencies (McLaughlin and Percy, 1999).

Many aspects affect the availability of $\mathrm{Ca}^{+2}$ and the rate at which $\mathrm{Ca}^{+2}$ is leached

from the soil. Some soil factors that determine $\mathrm{Ca}^{+2}$ availability to plants include total $\mathrm{Ca}^{+2}$ supply, soil $\mathrm{pH}, \mathrm{CEC}$, percentage of $\mathrm{Ca}^{+2}$ saturation on CEC sites, type of soil 
colloid, and the ratio of $\mathrm{Ca}^{+2}$ to other cations in solution (Halvin et al., 1999). Soil pH has an enormous affect on $\mathrm{Ca}^{+2}$ availability because as $\mathrm{pH}$ decreases, $\mathrm{Ca}^{+2}$ leaching increases. McLaughlin and Percy (1999) stated that acidic deposition is known to approximately double leaching rates that occur naturally. In a southeastern U.S. forest, Huntington et al. (2000) noted $\mathrm{Ca}^{+2}$ loses due to leaching to be approximately $2.7 \mathrm{~kg} \mathrm{ha}^{-1}$ $\mathrm{yr}^{-1}$, whereas in the more acid-polluted region of the northeast Federer et al. (1989) found $\mathrm{Ca}^{+2}$ to be leaching at a rate of 10 to $22 \mathrm{~kg} \mathrm{ha}^{-1} \mathrm{yr}^{-1}$. Knoepp and Swank (1994) considered leaching to be the primary source of $\mathrm{Ca}^{+2}$ loss from the Ultisol soils in their study in the southern Appalachians. Trettin et al. (1999) also noted leaching as an important cause of $\mathrm{Ca}^{+2}$ loss from their upland-forested sites in Oak Ridge, Tennessee, but associated vegetation uptake as the major source of $\mathrm{Ca}^{+2}$ depletion. In addition to acidification increasing leaching, Trettin et al. (1999) found low-lying, depressional areas to have the greatest loss of soil $\mathrm{Ca}^{+2}$. This was attributed to the low-lying areas functioning as a collection pont for water thereby increasing potential for leaching. Furthermore, tree species can affect $\mathrm{Ca}^{+2}$ depletion in a soil. Huntingtion et al. (2000) noted that hardwoods accumulate more $\mathrm{Ca}^{+2}$ than softwoods and that hardwood species dominated the sites with the highest net depletion rates and the lowest exchangeable $\mathrm{Ca}^{+2}$ inventories in the soil.

Calcium is replenished in the soil through mineral weathering, biocycling, and through atmospheric deposition. In the highly weathered soils often found in the old Appalachian mountains, the potential for replenishment for soil exchangeable $\mathrm{Ca}^{+2}$ is low. In a study conducted in Oak Ridge, Tennessee, Trettin et al. (1999), found that Ultisols and soils occurring on ridge-tops were highly weathered and were probably not 
contributing much to the release of $\mathrm{Ca}^{+2}$ into the soil system. Generally, biocycling can maintain adequate nutrients for tree growth, but once biological cyclying is disrupted through forest harvesting, bases can be lost rapidly due to leaching (Huntington et al., 2000). Atmospheric deposition contributes to the $\mathrm{Ca}^{+2}$ supply of soil, however it only provides approximately $25 \%$ of the wood requirement for this cation, and this does not take into account leaching losses that occur once the cation is deposited (Huntington et al., 2000).

Many studies have shown that evaluating the molar $\mathrm{Ca}: \mathrm{Al}$ ratio of soils is an important diagnostic tool for assessing forest soil stress due to high $\mathrm{Al}^{+3}$ concentrations (Cronan and Grigal, 1995; Lyon and Sharpe, 1999; Schoenholtz et al., 2000; Jenkins, 2001). Elevated $\mathrm{Al}^{+3}$ concentrations and an imbalance of $\mathrm{Ca}: \mathrm{Al}$ in soil solutions can inhibit $\mathrm{Ca}^{+2}$ uptake, diminish fine root growth, disturb photosynthetic activity, and lead to nutrient imbalances in forest tree species (Lyon and Sharpe, 1999; Shoenholtz et al., 2000). If the $\mathrm{Ca}: \mathrm{Al}$ ratio falls below 1.0, the risk of adverse effects on forest physiological functions increase (Cronan and Grigal, 1995). Cronan and Grigal (1995) established the following three stress risk levels related to $\mathrm{Ca}: \mathrm{Al}$ ratios:

1. If the ratio was between 0.5 and 1 , the soil was at a $50 \%$ risk level for producing $\mathrm{Al}^{+3}$ stress to trees,

2. If the ratio was between 0.2 and 0.5 , the soil had a $75 \%$ chance for producing $\mathrm{Al}^{+3}$ stress to trees, and

3. If the ratio was less than 0.2 , the soil was at a 95 to $100 \%$ risk level for generating $\mathrm{Al}^{+3}$ stress to vegetation. 


\section{Base Saturation}

Base saturation (BS) indicates a relative level of base nutrient availability. When base saturation is low, $\mathrm{Al}$ is the dominant cation available for exchange and this could lead to reduced productivity due to aluminum toxicities and nutrient imbalances (Adams et al., 2000). In a review of chemical and physical properties of forest soils, Shoenholtz (2000) stated that in acid forest soils, base saturation was more important to the soils nutrient supplying power than CEC. Since soil acidification is a natural process in forest ecosystems, and since base cations are not routinely added, percent base saturation determines the influence of the exchange complex on soil solution chemistry and acidity.

In addition to being an indicator of aluminum toxicities and nutrient imbalances, base saturation also can be used as a guide for acid toxicity risks. In a study by Meiwes et al. (1986), threshold values of base saturation were established for the organic layer of forest soils to indicate the risk of acid toxicity to fine roots and mycorrhizal fungi. Three categories were established to represent these threshold levels as follows:

1. Little risk-BS values greater than $10 \%$ in the organic layer

2. Medium risk-BS values between 5 and $10 \%$ in the organic layer

3. High risk-BS values less than $5 \%$ in the organic layer.

By using these values as a guide, one can predict whether or not symbiotic fungi and fine roots are in danger of adverse effects from acid toxicity. 


\section{Sulfate and Sulfate Adsorption Capacity}

Sulfate, the major form of inorganic $\mathrm{S}$ in forest soils, is derived from wet and dry deposition, mineral weathering, and catabolism of organic S (Mitchell et al., 1992).

Sulfur may be retained by either geochemical or abiotic processes including adsorption and mineral formation or by the biochemical or biotic mechanisms of plant uptake and microbial immobilization.

Adsorption of $\mathrm{SO}_{4}^{-2}$ is generally considered to take place by two mechanisms: nonspecific adsorption where the anion is retained by electrostatic forces and secondly, by specific adsorption where the anion is bound covalently (Evangelou, 1998). The first adsorption mechanism results in an equivalent release of another anion, typically $\mathrm{OH}^{-}$, especially in low pH soils (Fuller et al., 1985). This suggests an adsorption mechanism whereby the negative charge of $\mathrm{SO}_{4}^{-2}$ adsorbed onto an $\mathrm{Al}^{+3}$ or iron hydroxide surface is balanced by displacement of the $\mathrm{OH}^{-}$ion (Mitchell et al., 1992; Fuller et al., 1985). The second term, specific adsorption, is used for all adsorption that cannot be entirely explained by electrostatic forces (Mitchell et al., 1992; Fuller et al., 1985).

Much research has focused on $\mathrm{SO}_{4}^{-2}$ retention and release in forested ecosystems, especially with respect to the affects of atmospheric deposition (Adams et al., 2000; Johnson et al., 1999; Spratt, 1998; Prenzel and Meiwes, 1994; Shaffer and Stevens, 1991; MacDonald and Hart, 1990; Harrison et al., 1989; Khanna et al., 1987; and Fuller et al., 1985). Through these and various other reports, it has become widely accepted that soils receiving increasing $\mathrm{SO}_{4}^{-2}$ via atmospheric deposition are in jeopardy of becoming $\mathrm{SO}_{4}{ }^{-2}$ saturated. If deposition continues, soils will begin releasing $\mathrm{SO}_{4}{ }^{-2}$, as well as, $\mathrm{H}^{+}, \mathrm{Al}^{+3}$ and beneficial nutrient cations into the groundwater system. This can cause an already 
low $\mathrm{pH}$ soil to become more acidic with the potential for aluminum toxicity and nutrient deficiency.

It has also been determined, that net retention of $\mathrm{SO}_{4}{ }^{-2}$ can potentially decrease the transport of potentially toxic $\mathrm{H}^{+}$and $\mathrm{Al}^{+3}$ to surface waters, and aid in retaining nutrient-rich, basic cations (Fuller et al., 1985; Harrison et al., 1989; Arbestain et al., 1999). Adsorption of $\mathrm{SO}_{4}{ }^{-2}$ by soils is concentration dependent: soils will retain additional $\mathrm{SO}_{4}{ }^{-2}$ as input levels of $\mathrm{SO}_{4}{ }^{-2}$ increase up until $\mathrm{SO}_{4}{ }^{-2}$ saturation, or steady state occurs (Adams et al., 2000). Sulfate saturation takes place when the soil is no longer accepting $\mathrm{SO}_{4}{ }^{-2}$ onto soil adsorption sites at ambient precipitation levels (Adams et al., 2000). The reverse is also true. If the input concentration of $\mathrm{SO}_{4}{ }^{-2}$ decreases and adsorption is reversible, decreased adsorption and increased $\mathrm{SO}_{4}{ }^{-2}$ and cation leaching could result (Harrison et al., 1989). Johnson et al. (1999) observed reductions in soil solution $\mathrm{SO}_{4}{ }^{-2}$ and $\mathrm{Al}^{+3}$ after a $50 \%$ reduction in $\mathrm{N}$ and $\mathrm{S}$ deposition. However, these soils were already $\mathrm{SO}_{4}{ }^{-2}$ saturated and the reduction of $\mathrm{SO}_{4}{ }^{-2}$ in solution was a direct result of the decreased $S$ in the deposition. In soils still capable of retaining sulfate, the increase of soil solution $\mathrm{SO}_{4}{ }^{-2}$ (and associated cations) is decreased over time until the soil becomes equilibrated with the input concentration of $\mathrm{SO}_{4}^{-2}$ (Harrison et al., 1989).

Inputs of S to the soil depend upon various environmental factors including atmospheric concentrations of $\mathrm{SO}_{2}, \mathrm{H}_{2} \mathrm{SO}_{4}$ and neutral salts, seasonal variations, and the canopy and site characteristics of a forest stand (Khanna et al.,1987; Fuller et al., 1985). Site properties such as elevation and vegetation type affect atmospheric $\mathrm{SO}_{4}^{-2}$ loading rates (e.g. greater precipitation, cloud deposition, and less evapotranspiration at higher elevations) and as a result influence both $\mathrm{SO}_{4}{ }^{-2}$ deposition and adsorption (Fuller et al., 
1985). Khanna et al. (1987) observed that forest soils in their study received higher inputs of $\mathrm{S}$ in winter months than in the summer months. They also noted that more atmospheric $\mathrm{SO}_{4}^{-2}$ was deposited at spruce (Picea rubens) sites than in beech (Fagus grandifolia) stands.

Adsorption and retention of $\mathrm{SO}_{4}^{-2}$ is dependant upon a multitude of soil characteristics, including soil pH (Adams et al., 2000; Prenzel and Meiwes, 1994; Mitchell et al., 1992), parent material (Arbestain et al., 1999), soil horizon type (Arbestain et al., 1999; MacDonald and Hart, 1990; Adams et al., 2000) organic carbon (MacDonald and Hart, 1990; Mitchell et al., 1992; Adams et al., 2000), Fe and Al oxides (Khanna et al., 1987; Mitchell et al., 1992; Adams et al.,2000) and percent clay (MacDonald and Hart, 1990; Mitchell et al., 1992; Adams et al., 2000). Obviously, there are many soil properties that affect the adsorption of $\mathrm{SO}_{4}{ }^{-2}$, hence making it difficult to pinpoint the exact reason why one soil may have a greater capacity than another to retain the anion. In addition, not all of the research is congruent, especially with how $\mathrm{pH}$ effects the adsorbing capability of the soil.

When soil is acidified, $\mathrm{SO}_{4}^{-2}$ adsorption will tend to increase (Arbestain et al., 1999; Mitchell et al., 1992). This is related to the increased positive surface charge that variable-charged soils acquire as $\mathrm{pH}$ decreases, thus increasing the retention of additional anions. When the $\mathrm{pH}$ of soils was artificially increased by liming, Prenzel and Miewes (1994) found that $\mathrm{SO}_{4}{ }^{-2}$ in solution (leaching) increased. In addition, MacDonald and Hart (1990) established that soils having a higher $\mathrm{pH}$ had lower $\mathrm{SO}_{4}{ }^{-2}$ adsorption. In contrast, however, $\mathrm{SO}_{4}^{-2}$ adsorption was higher in soils developing naturally from baserich material having abundant $\mathrm{Fe}$ and $\mathrm{Al}$ oxy-hydroxides compared with that occurring in 
soils developed from more acidic materials in the study by Arbestain et al. (1999). The reasons for this contrast were related to the actuality that there was not always a direct correlation between $\mathrm{pH}$ and $\mathrm{SO}_{4}{ }^{-2}$ adsorption due to extraneous factors such as organic matter and parent material. Harrison et al. (1989) found a significant positive relationship between $\mathrm{SO}_{4}{ }^{-2}$ adsorption and $\mathrm{pH}$. And in still another study, Khanna et al. (1987) found that as $\mathrm{pH}$ decreased, $\mathrm{SO}_{4}{ }^{-2}$ and $\mathrm{Al}^{+3}$ leaching increased. Some possible explanations to the apparent discrepancies among experiments could be due to differences in procedure. Also, $\mathrm{Al}$ and $\mathrm{Fe}$ oxides provide adsorption surfaces for $\mathrm{SO}_{4}{ }^{-2}$, and a low $\mathrm{pH}$ may result in solubilization of surface coatings of these oxides, thus destroying the $\mathrm{Fe}$ and $\mathrm{Al}$ adsorption site, ultimately reducing $\mathrm{SO}_{4}{ }^{-2}$ retention (Mitchell et al., 1992; Harrison et al., 1987).

Organic $\mathrm{C}$ was found to be negatively correlated with $\mathrm{SO}_{4}{ }^{-2}$ adsorption in a Michigan forest soil study (MacDonald and Hart, 1990). Fuller et al. (1985) also agreed that soils with higher accumulations of organic $\mathrm{C}$ adsorbed lower amounts of $\mathrm{SO}_{4}{ }^{-2}$ and this phenomena was attributed to the organic matter actually blocking the anion adsorption sites. Mitchell et al. (1992) concurred, stating that organic matter was a competing ligand and may decrease $\mathrm{SO}_{4}{ }^{-2}$ adsorption. Arbestain et al. (1999), however, found that organic $\mathrm{C}$ was not strongly correlated with the adsorption of $\mathrm{SO}_{4}{ }^{-2}$, but they did state that organic matter apparently had counteracting effects on $\mathrm{SO}_{4}{ }^{-2}$ sorption. They attributed this to different counteracting mechanisms: (i) a negative mechanism, whereby dissolved organic $\mathrm{C}$ and $\mathrm{SO}_{4}{ }^{-2}$ directly compete for sorption sites thus decreasing $\mathrm{SO}_{4}{ }^{-}$ ${ }^{2}$ sorption and (ii) positive mechanisms, whereby an increase in reactive surface is achieved by either stabilization of $\mathrm{Al}$ and $\mathrm{Fe}$ in $\mathrm{Al}$ - and Fe-humus complexes, or 
association of minerals of low crystallinity with organic matter thus delaying the crystallization of $\mathrm{Al}$ and $\mathrm{Fe}$ oxides.

Most studies agree that there is a positive relationship between clay content and $\mathrm{SO}_{4}{ }^{-2}$ adsorption capacity. MacDonald and Hart (1990) found that $\mathrm{SO}_{4}{ }^{-2}$ adsorption capacity increased as clay percentage in forest soil increased. Adams et al. (2000) stated that soils sensitive to $\mathrm{SO}_{4}{ }^{-2}$ saturation were those with relatively low clay content.

Amounts of $\mathrm{Fe}$ and $\mathrm{Al}$ in soils, especially extractable $\mathrm{Al}$, appear to affect the retention of $\mathrm{SO}_{4}{ }^{-2}$ in soils. As stated earlier, $\mathrm{Fe}$ and $\mathrm{Al}$ oxides provide surfaces for adsorption of $\mathrm{SO}_{4}{ }^{-2}$ (Mitchell et al. 1992). Fuller et al. (1985), MacDonald and Hart (1990), and Arbestain et al. (1999) were in general agreement that there was a strong positive relationship between different extractable forms of $\mathrm{Fe}$ and $\mathrm{Al}$ occurring in soil and the $\mathrm{SO}_{4}{ }^{-2}$ adsorption capacity of the soil. In the Harrison et al. (1989) study of forest soils, $\mathrm{SO}_{4}^{-2}$ adsorption by Inceptisols and Spodosols was most closely related to the concentration of oxalate extractable Al. Ultisols, however, did not appear to have a correlation with any of the Fe or Al extractions measured.

Sulfate adsorption capacity may vary by soil horizon. Arbestain et al. (1999) established that subsurface horizons tended to retain higher amounts of $\mathrm{SO}_{4}^{-2}$ than did surface horizons. This is probably most related to the decreased organic matter content in the lower horizons and increased clay content. MacDonald and Hart (1990) found that all A horizons and some E horizons of Michigan forest soils had a lower ability to adsorb $\mathrm{SO}_{4}^{-2}$ and were releasing the anion into the soil system. Again, the research suggested that this was attributable to high organic matter contents in the A horizons masking the 
adsorption sites and the coarse-textured nature of the $\mathrm{E}$ horizons not being conducive to adsorption.

\section{Biomass and Productivity}

Biomass determination is an aid to management of forested ecosystems. It gives foresters and others an idea of the amount of material the forest is producing, as well as identifying problem areas where productivity is being hindered. Species, stand age, and stocking rate determine the amount of forest biomass on a site (Vitousek et al., 1988). Some factors affecting biomass and productivity include soil nutrient status (Frank et al., 1984; Hicks and Frank, 1984; Adams, et al., 2000; Huntington et al., 2000 ), organic matter content (Hicks and Frank, 1984; Jenkins, 2001), pH and acidification (Adams, et al., 2000), aspect --affecting soil temperature and moisture (Frank et al., 1984; Hicks and Frank, 1984), bulk density and soil compaction--affecting porosity, infiltration rate, hydraulic conductivity (McNabb et al., 2001), and slope and surface erosion (Grigal, 2000).

In a West Virginia study of a 50-yr-old hardwood forest (Frank et al., 1984), it was found that the following soil-site variables affected biomass: aspect, iron and copper in the B horizon, calcium in the A and B horizons, surface stoniness, and A horizon manganese, potassium and iron. Iron in the A and B horizons had a negative affect on total dry weight indicating possible iron toxicity, while copper and calcium in the B horizon had a positive relationship with biomass demonstrating deficiency possibilities 
for these elements. Lime requirement, surprisingly, had a non-significant correlation to biomass, despite the relatively low $\mathrm{pH}$ of the soils in their study.

In this and similar studies, aspect has been shown to greatly affect biomass and productivity as well. Hicks and Frank (1984) stated that in general, south and westfacing slopes were the least productive and north and east facing slopes were the most productive. They found many factors to be associated with this phenomenon. Higher values, of $\mathrm{Ca}, \mathrm{K}, \mathrm{Mn}$, and $\mathrm{P}$ were associated with north and east-facing slopes, while $\mathrm{Fe}$, $\mathrm{Al}$ and $\mathrm{H}$ occurred in lower concentrations. The opposite was true for the less productive south and west-facing slopes. Also, soil moisture and accumulation of organic matter were related to aspect. Increased net radiation on south and southwest slopes elevated surface temperatures and drying of litter. The drier litter decomposed more slowly which provided less favorable conditions for soil vegetation and organisms, further slowing decomposition and increasing litter accumulation. The complex energy balance and soil nutrients on these aspects affected site vegetation and thus produced a less palatable litter for organic decomposition. The authors also recognized that particular trees were associated with certain aspects. They found, in general, that trees with leaves higher in lignin, such as various oaks (Quercus L.), sassafras (Sassafras albidum) and cucumber (Magnolia acuminata), were more often located on south and west-facing slopes, while trees associated with north and east aspects were more likely species such as red maple (Aceraceae rubrum), yellow poplar (Liriodendron tulipifera), hickory (Carya L.), and black cherry (Prunus serotina).

In recent years, forest soil nutrient status and its effects on biomass and productivity has been a major focus of research. Fertility of the soil environment affects 
the amounts and kinds of biomass inputs (Jenkins, 2001). Nitrogen was historically believed to be the element most limiting to forest growth, but studies show that $\mathrm{Ca}^{+2}$ was more likely to be significantly depleted by harvesting and leaching, and this may threaten long-term sustainability of forest productivity (Huntington et al., 2000). Numerous studies have shown that many forest soils of today have an ample $\mathrm{N}$ supply from external source of anthropogenic processes (Rennenberg and Gressler, 1999; Garten, 2000; SteMarie and Pare, 1999; Huntington et al., 2000; McLaughlin and Percy, 1999; and Adams et al., 2000). However, $\mathrm{Ca}^{+2}$ has not been replenished by atmospheric deposition. Huntington et al. (2000) found atmospheric deposition to provide $75 \%$ of the estimated wood requirement for $\mathrm{N}$, while only supplying approximately $25 \%$ of the wood need for $\mathrm{Ca}^{+2}$. They also calculated that $\mathrm{Ca}^{+2}$ depletion would probably reduce soil reserves to less than the requirement for a merchantable forest stand in approximately $80 \mathrm{yr}$ in the Peidmont forest of their study. In addition, the acid parent material that is often found in Appalachian forests will not provide much additional $\mathrm{Ca}^{+2}$ to developing soils (Jenkins, 2001). Other studies have shown that $\mathrm{Ca}^{+2}$ depletion was not a major concern and that harvest removals of $\mathrm{Ca}^{+2}$ were generally replaced within one rotation (Grigal, 2000; Johnson and Todd, 1998, and Knoepp and Swank, 1994). Obviously, the need for more research on the limiting nutrient status of forest soils is great and the uncertainties associated with the effects of nutrient removal on productivity need to be further evaluated.

There have been numerous reports on the various methods to determine forest biomass (Wharton and Griffith, 1998; Young et al., 1980; Wiant et al., 1979). Through these studies, equations were generated relating total dry biomass to stand volume, using 
techniques based on diameter at breast height (DBH) and/or height of trees, seedlings and shrubs. In a West Virginia forest soil study, Jenkins (2001) found that out of all forest biomass inputs, sawtimber-sized trees ( $>12.7 \mathrm{~cm} \mathrm{DBH})$ comprised $79 \%$ to $92 \%$ of total site biomass. He also estimated total vegetative biomass for this Appalachian forest to range from 159 to $297 \mathrm{Mg} \mathrm{ha}^{-1}$. Brown et al. (1999) reported similar biomass estimations for a West Virginian forest, with values varying from 180 to $220 \mathrm{Mg} \mathrm{ha}^{-1}$.

\section{METHODS AND MATERIALS}

\section{Site Description and Location of Soils}

The research site is located in the Otter Creek Wilderness Area in the Cheat Ranger district of the Monongahela National Forest in Tucker and Randolph Counties, West Virginia (Figure 1). The area consists of various landforms occurring on a variety of geologic formations including the Conemaugh, Allegheny, Kanawha, and New River of Pennsylvanian age and the Mauch Chunk group from the Mississippian System (Figure 2). These formations are composed primarily of sandstone, shale, and mudstone with some zones containing limestone and siltstone. Elevation ranges from $550 \mathrm{~m}$ to $1190 \mathrm{~m}$, so temperature can vary considerably, with the average daily maximum around $18^{\circ} \mathrm{C}$ and the average daily minimum about $4^{\circ} \mathrm{C}$. The yearly precipitation average for this region is approximately $125 \mathrm{~cm}$, and average relative humidity is high. The major vegetation in Otter Creek is Norway spruce (Picea abies), hemlock (Tsuga conadensis), yellow birch (Betula alleghaniensis), sugar maple (Acer saccharium), red maple (Acer 
rubrum), beech (Fagus grandifolia) and widely distributed rhododendron (rhododendron spp.) The major soils are alfisols, ultisols, inceptisols, and some spodosols (Losche and Beverage, 1967).

Thirteen sampling sites were chosen throughout the Otter Creek Wilderness by USDA Natural Resource Conservation Service (NRCS) soil scientists (Figure 2). The latitude and longitude of these sites are noted in the profile descriptions in Appendix A. These sites were sampled in August 1999 and 2000. They were selected to represent soils for which no previous data existed. These locations represented a range in soil mapping units, geologic formations and landscape positions.

\section{Field Procedures}

A soil pit was dug at each of the 13 sites (eight in 1999 and five in 2000) to a minimum depth of $99 \mathrm{~cm}$ with 11 of the 13 pits having depths exceeding $150 \mathrm{~cm}$. All organic and mineral horizons were described by NRCS soil scientists according to cooperative soil survey guidelines (Soil Survey Staff, 1993). Most soils were described and sampled on the same day. Usually, vegetation, slope, and parent material were noted, as well as the longitude and latitude of the site. A large bulk sample was taken from each horizon and placed into a sampling bag for subsequent analyses. All samples were taken to West Virginia University where physical, chemical and mineralogical analyses were performed in the laboratories of the Division of Plant and Soil Sciences. 


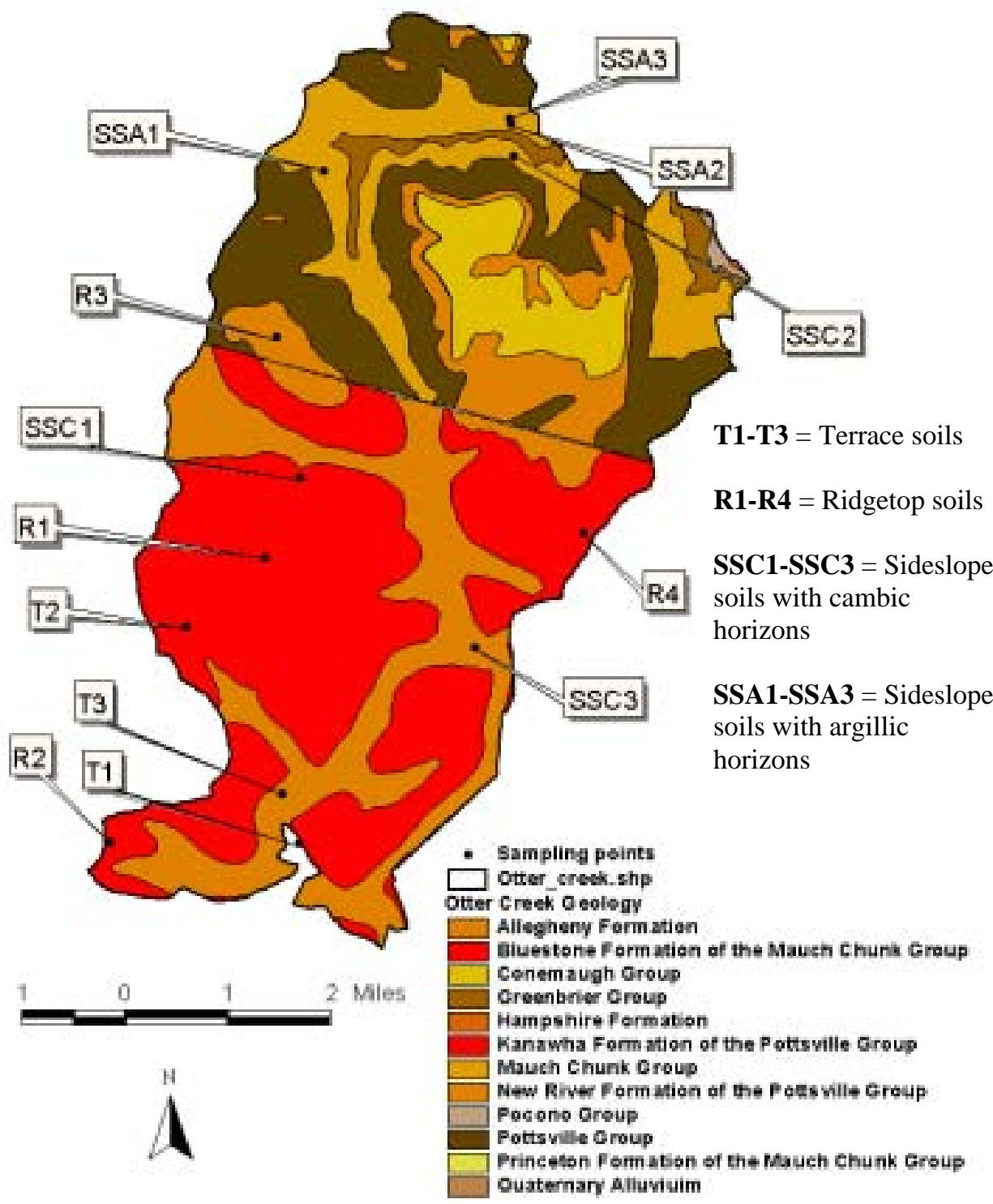

Figure 2. Geology of the Otter Creek Wilderness with soil pedon sites located. 


\section{Laboratory Analyses}

\section{Physical Properties}

Each bulk sample was air dried and sieved to remove rock fragments from the fine earth fraction ( $<2 \mathrm{~mm}$ particle size diameter). The resulting rock fragments and soil components were weighed and rock fragment percentage, by weight, for each horizon was calculated. The soil sample of $<2 \mathrm{~mm}$ was then used for the remaining physical, chemical, and mineralogical analyses.

Two to four soil clods per horizon were used to determine total bulk density and bulk density <2 mm by the saran coated clod method (Soil Survey Staff, 1996). After the weight and volume of each clod were determined, the clods were broken apart and sieved for rock fragments. The corrected bulk density $(<2 \mathrm{~mm})$ was then calculated.

In order to determine the bulk density of the organic horizons and some of the A horizons where clods could not be collected, a frame excavation method was used (Grossman and Reinsch, 2002). Again, rock fragments were removed and a corrected bulk density $(<2 \mathrm{~mm})$ for the horizons was established.

Texture was determined by the pipette method using 500-ml Fleakers (Indorante et al., 1990). Organic matter was removed using $3 \%$ hydrogen peroxide with simultaneous heating to $80{ }^{\circ} \mathrm{C}$ on a hotplate. No treatments were utilized to remove carbonates from the soils due to low sample $\mathrm{pH}$. It was assumed that little or no carbonates would be present. The sand portion of each sample was shaken through a nest of sieves at 500 oscillations per minute for 3 minutes. The openings of the sieves were $1.00 \mathrm{~mm}, 0.50 \mathrm{~mm}, 0.25 \mathrm{~mm}, 0.10 \mathrm{~mm}$, and $0.05 \mathrm{~mm}$, which separated very coarse, coarse, medium, fine, and very fine sands, respectively. One sample for each mineral 
horizon was examined for particle size and a duplicate sample was run for one out of every four horizons.

\section{Chemical Properties}

Soil reaction $(\mathrm{pH})$ was determined on a 1:1 water to soil suspension on all mineral horizons and a 2:1 to 8:1 water to soil suspension on all organic horizons depending on consistency (Method 8C1, Soil Survey Staff, 1996). Soil pH also was determined for a 2:1 $\mathrm{CaCl}_{2}$ to soil suspension on all mineral horizons and a $4: 1$ to $16: 1 \mathrm{CaCl}_{2}$ to soil suspension on the organic layers (Method 8C1e, Soil Survey Staff, 1996). A Fisher Scientific Accumet $915 \mathrm{pH}$ meter was used to measure the $\mathrm{pH}$ in both methods.

Following the 1:1 $\mathrm{pH}$ measurements, additional distilled-deionized water was added to all mineral horizons creating a 2:1 water to soil solution. The organic soil horizons were freshly mixed to various ratios of water to soil, ranging from 3:1 to $12: 1$, again, depending on consistency. The mixtures were stirred, and electrical conductivity was determined by a Markson 4603 Solution Analyzer.

Total carbon, nitrogen, and sulfur were measured by combustion in a LECO CNS 2000 analyzer.

Average soil organic carbon (SOC) stocks were determined for each soil pedon. Calculations were made to $150 \mathrm{~cm}$ or to bedrock, whichever was shallower. Total pedon SOC stock $\left(\mathrm{SOC}_{\mathrm{p}}\right)$ was calculated as the sum of the individual horizon SOC stocks $\left(\mathrm{SOC}_{h}\right)$ (Jenkins, 2001). Soil organic carbon for each horizon $\left(\mathrm{SOC}_{h}\right)$ was found using equation [3]:

$$
\mathrm{SOC}_{\mathrm{h}}=\% \mathrm{C} / 100 \times \mathrm{Db} \times \mathrm{H} \times(1-\% \mathrm{RF} / 100) \times 1000 \mathrm{~kg} / \mathrm{Mg}
$$


where: $\mathrm{SOC}_{\mathrm{h}}=$ Horizon SOC in $\mathrm{kg} \mathrm{m}^{-2} ; \% \mathrm{C}=$ percent organic carbon of oven-dry soil $<2 \mathrm{~mm}$ fraction; $\mathrm{Db}=$ bulk density $\left(\mathrm{Mg} \mathrm{m}^{-3}\right) ; \mathrm{H}=$ horizon thickness in $\mathrm{m} ; \% \mathrm{RF}=$ volume percent rock fragments $>2 \mathrm{~mm}$.

Extractable aluminum (Al) was determined using an automatic extractor and $1 \mathrm{~N}$ $\mathrm{KCl}$ as the extractant (Method 6G, Soil Survey Staff, 1996). Aluminum was determined by atomic absorption spectrophotometry on a Perkin Elmer AAnalyst 100.

The extractable acidity of the samples was released by using a barium chloridetriethanolamine $\left(\mathrm{BaCl}_{2}\right.$-TEA) solution buffered at $\mathrm{pH} 8.2$ (Method 6H, Soil Survey Staff, 1996). The extracted solution was then titrated with $0.1 \mathrm{~N} \mathrm{HCl}$ with the titration endpoint for the $\mathrm{BaCl} 2-\mathrm{TEA}$ set at $\mathrm{pH}$ 4.6. A Radiometer/ Copenhagen ABU93 Triburette titrator system was used.

Extractable calcium $\left(\mathrm{Ca}^{2+}\right)$, magnesium $\left(\mathrm{Mg}^{2+}\right)$, sodium $\left(\mathrm{Na}^{+}\right)$, and potassium $\left(\mathrm{K}^{+}\right)$ were determined using the ammonium acetate $(\mathrm{pH} 7.0)$ with the automatic extractor method (Method 5A8, Soil Survey Staff, 1996). The cations $\mathrm{Ca}^{2+}$ and $\mathrm{Mg}^{2+}$ were measured on an inductively coupled plasma emission spectrophotometer (Perkin Elmer Plasma 400), and $\mathrm{Na}^{+}$and $\mathrm{K}^{+}$were analyzed on an atomic absorption spectrophotometer (Perkin Elmer AAnalyst 100). The addition of these bases plus $\mathrm{BaCl}_{2}$-TEA acidity yielded cation exchange capacity (CEC) via summation. Cation exchange capacity also was determined on samples extracted by ammonioum acetate $(\mathrm{pH} 7.0)$ by steam distillation of ethanol washed samples on a Kjeldhal N analyzer (Method 5A8b, Soil Survey Staff, 1996). Percent base saturation (\%BS) was calculated by multiplying the sum of the extractable bases by 100 and dividing by the CEC determined by summation. 
Effective cation exchange capacity (ECEC) was determined by adding $\mathrm{KCl}$ extractable $\mathrm{Al}$ to the sum of the ammonium acetate extractable bases. Cation exchange capacity activity ratio was determined by dividing ammonium acetate CEC by percent clay. Apparent CEC was defined as ammonium acetate CEC per kilogram clay. This resulted in CEC being divided by the decimal of the total clay percentage.

The Bray P-1 method was used to determine extractable phosphorus (P) (Method 6S, Soil Survey Staff, 1996). Filtrates were analyzed on an inductively coupled plasma emission spectrophotometer.

Sulfate in each sample $(20 \mathrm{~g})$ was extracted with $0.05 \mathrm{~L}$ of $0.0081 M \mathrm{Ca}\left(\mathrm{H}_{2} \mathrm{PO}_{3}\right)_{2}$ and analyzed on a Zellweger Analytics Lachat Quik Chem 8000. Extractable sulfate $\left(\mathrm{SO}_{4}\right)$ was determined turbidimetrically by flow injection analysis (Egan, 1998).

Sulfate adsorption capacity of the soils was found by equilibrating 10-g samples with $0.05 \mathrm{~L}$ of $0.312 \mathrm{mmol} \mathrm{SO}_{4} \mathrm{~L}^{-1}$ in $0.01 \mathrm{M} \mathrm{CaCl}_{2}$ (MacDonald and Hart, 1990). The samples were shaken for one hour on a wrist action shaker. Color (due to organic matter) removal by charcoal was insufficient. Color tainted solutions were corrected for impurities by running water blanks and subtracting the water value from the original read-out. A Zellweger Analytics Lachat Quik Chem 8000 was used for the analyses. Adsorbed sulfate was calculated from the disappearance of sulfate from solution.

Total elemental analysis was determined by total soil digestion using a combination of hydrofluoric, nitric, and boric acids (Soil Survey Staff, 1996). Modifications to the published procedure included substituting boric acid solution for solid boric acid. Also, a second digestion step was performed after the boric acid was added. The digestion was done in a CEM Mars5 microwave system and $\mathrm{Al}, \mathrm{Ca}, \mathrm{Cu}, \mathrm{Fe}$, 
$\mathrm{Mg}, \mathrm{Mn}, \mathrm{P}$, and $\mathrm{Zn}$ were determined on an inductively coupled plasma emission spectrophotometer. Sodium and K were measured on an atomic absorption spectrophotometer. Boron (B) could not be determined because of the procedure that was used. A Montana soil standard (reference number-2711) also was analyzed to ensure proper procedure for total elemental analysis.

\section{Clay Mineralogy}

Clay mineralogy of a major solum horizon from each pedon (13 in all) was determined by x-ray diffraction. A pretreatment of $30 \%$ hydrogen peroxide was used to remove organic matter from each 5-g sample (Method 7A1b, Soil Survey Staff, 1996). Removal of carbonates was deemed unnecessary due to the low $\mathrm{pH}$ of the samples. Also, no care was taken to remove iron from the soils because of newer technology allowing for little or no iron interference (Renton, J., 2002, Professor of Geology, WVU, personal communication).

Each sample was dispersed with sodium hexametaphosphate and shaken overnight. Sands were removed by sieving through a 300-mesh sieve. The subsequent silt and clay suspension was collected and centrifuged at $750 \mathrm{rpm}$ for 3 minutes. The clay was decanted and the silt discarded. The clay was separated into two samples and prepared for glass slides (Method 7A2a, Soil Survey Staff, 1996).

One clay sample (approx. 10mL clay solution) was saturated with $\mathrm{MgCl}_{2}$ (1:1 clay suspenstion to $\mathrm{MgCl}_{2}$ ) and the other sample saturated with $\mathrm{KCl}$ (1:1 clay suspension to $\mathrm{KCl}$ ) (Bhumbla, D.K., Assistant Professor of Soil Science, WVU, personal communication). This initial step was done to flocculate the clays. The samples were 
centrifuged and the supernatant was discarded. In a 50-ml centrifuge tube, about $40 \mathrm{ml}$ of $1 \mathrm{M} \mathrm{MgCl}$ was added to the $\mathrm{Mg}$-saturated samples and $40 \mathrm{ml}$ of $1 \mathrm{M} \mathrm{KCl}$ was added to the K-saturated samples. The samples were vortexed to ensure that the respective ions made contact with all clay particles, and the clays were centrifuged around 1500rpm for 15 minutes. The supernatant was discarded and the clays were washed three or four times with distilled-deionized water. An eyedropper was used to collect a small clay sample and place it on a round glass slide. Each slide was subjected to x-ray diffraction.

The slides were then returned for further treatment. The Mg-saturated slides underwent glycerol solvation by being placed in a covered glass pan containing a layer of ethylene glycol. The slides rested on a raised mesh apparatus so that they were not lying directly in the glycerol. This treatment helps identify any montmorillonite in the clay sample. The K-saturated slides were heated in a muffle furnace at $550{ }^{\circ} \mathrm{C}$ for 4 hours. The heating process allows for chlorite identification.

\section{Biomass Accumulation}

At each site, above-ground biomass was sampled during the time of soil sampling. Biomass data for sawtimber, standing dead vegetation, sapling, seedling, and shrub layer were collected using criteria given in Table 1. These methods were developed by David Kingsbury (USDA-NRS), Robert Grossman (USDA-NRCS), and Linda Heath (USFS) (Biomass Sampling in the Northeastern United States. ND. National Survey Center, Lincoln, NE) as part of an unpublished protocol for carbon sequestration studies. 
Table 1. Criteria used for biomass data collection at each pedon location.

\begin{tabular}{lll}
\hline Parameter & Criteria & Variables measured \\
\hline Sawtimber & DBH $>12.7 \mathrm{~cm}$ & DBH, species \\
Standing dead vegetation & $\mathrm{DBH}>12.7 \mathrm{~cm}$ & DBH, species \\
Saplings & $2.5 \mathrm{~cm}<\mathrm{DBH}<12.7 \mathrm{~cm}$ & DBH, species \\
Seedlings & $0.25 \mathrm{~cm}<\mathrm{DBH}<2.5 \mathrm{~cm}$ & DBH, species \\
Seedlings & $30 \mathrm{~cm}<$ height $<120 \mathrm{~cm}$ & Height, species \\
Shrubs & Non-tree species & Height, species \\
\hline
\end{tabular}

Diameter at breast height $(\mathrm{DBH})$ was recorded at each site for sawtimber and dead trees within circular plots $(0.08 \mathrm{ha})$. Trees with split trunks, at or below breast height, were accounted for by reducing the biomass estimates by $50 \%$ for all trunks except one (Jenkins, 2001). Five subplots were established $11.3 \mathrm{~m}$ from the sampled soil pedon. A 2.07-m radius subplot was used for all saplings with a DBH of 2.5 to $12.7 \mathrm{~cm}$. A $1.13-\mathrm{m}$ radius subplot was used for saplings of 0.25 to $2.5 \mathrm{~cm}$, as well as all seedlings and shrubs, unless fewer than five individuals occurred, whereby the radius was increased to $2.07 \mathrm{~m}$ (Jenkins, 2001).

Allometric equations for approximation of whole tree biomass were used for estimating dry matter (Wharton and Griffith, 1998), including equations for saplings, seedlings, and shrubs as summarized by Young et al. (1980). Biomass was calculated using equation [4] for red maple, sugar maple, beech, red spruce, birch, and hemlock for sawtimber and saplings, $2.5 \mathrm{~cm} \mathrm{DBH}$ and larger (Wharton and Griffith, 1998). For 
yellow poplar, black cherry, and red oak, equation [5] was used. In each equation, $b_{0}$ and $b_{1}$ are species-specific coefficients. For these species, the equation only

$\operatorname{Ln} \mathrm{Y}=\mathrm{b}_{0}+\mathrm{b}_{1} \operatorname{Ln}(\mathrm{DBH})$

$\log Y=\log b_{0}+b_{1} \log (D B H)$

estimates above-ground biomass and a factor of 1.23 was employed to predict whole-tree biomass (above-ground multiplied by 1.23). This is a weighted average based on the other hardwood species in the area as noticed by Jenkins (2001). Species-specific coefficients from Young et al. (1980) were used in equation [4] and [5] for saplings with DBH from 0.25 to $2.5 \mathrm{~cm}$ and seedlings from 0.3 to $1.22 \mathrm{~m}$ tall. Equation [6] was used for shrubs, where D was median stem diameter.

$\mathrm{Y}=\mathrm{b}_{0}(\mathrm{D})^{\mathrm{b}}$

For species where no equation was published, an equation for a vegetative species most similar in density and growth habit was utilized. For basswood, the equation for yellow poplar was used, and the equation for sugar maple was used for ash. Trees that were dead were assumed to have lower densities than live trees, therefore the biomass estimates for these trees were reduced by $50 \%$ (Jenkins, 2001).

Rate of biomass accumulation at each site was determined by dividing the biomass data by approximate stand age (Appendix D). Stand age was determined from 
information provided by the USFS (Appendix D). Information for every site was available, except for pedons SSA2 and SSA3. An average of all the stand ages were taken and used for these two pedons to determine their productivity (personal communication, Stephanie Connolly, USFS).

\section{Statistical Analysis}

Comparisons among soils were analyzed by Analysis of Variance (ANOVA) and means were separated by Duncan's Multiple Range Test. Chemical and physical properties of horizons within pedons, as well as, biomass accumulation were compared among four landscape positions: terrace $(\mathrm{T})$, ridgetop $(\mathrm{R})$, sideslope with cambic horizon (SSC), and sideslope with argillic horizon (SSA). Only those data that were significant at $\mathrm{p}<0.05$ were reported.

\section{RESULTS AND DISCUSSION}

\section{MORPHOLOGY, GENESIS, AND FIELD OBSERVATIONS}

\section{Terraces}

There were three terrace soils sampled and described in this study (Appendix A). Each of these soils formed in alluvial/colluvial material from the New River and/or Kanawha sandstone (Fig. 2). The majority of the vegetation at these sites consisted of coniferous species, with some sites supporting yellow birch and red maple (Appendix D, Table 39). Elevations for these sites were fairly similar, varying from $957 \mathrm{~m}$ to $1030 \mathrm{~m}$. 
Each terrace location was nearly level to gently sloping, with slopes ranging from $2.5 \%$ to $5 \%$ (Table 2). All of these soils had more than 50\% rock fragments somewhere within each pedon. The average mineral solum thickness (A and B horizons) was $89.5 \mathrm{~cm}$ (Table 2). All of these soils were very deep, each exceeding $150 \mathrm{~cm}$ in depth. Two were somewhat poorly drained (T1 and T2) and one was moderately well drained (T3).

Every terrace soil had an organic layer. Two soils had at least one layer of each of the three organic horizons (Oi, Oe, Oa), while the third soil (T3) only contained an Oi and Oe horizon. The thickness of these organic layers ranged from 11 to $15 \mathrm{~cm}$ (Table 2). Two of the three soils (T1 and T2) had E horizons and gleyed horizons, but $\mathrm{T} 3 \mathrm{had}$ neither one. All T soils had redoximorphic features, however, somewhere throughout the pedon. The two similar soils had sandier textures than the T3 soil.

Table 2. Average organic horizon thickness (O), mineral solum thickness (MS), slope, and drainage class of Otter Creek soils.

\begin{tabular}{ccccc}
\hline & Terrace & Ridgetop & Sideslope--Cambic & Sideslope--Argillic \\
\hline $\mathrm{O}(\mathrm{cm})^{1}$ & 12.7 & 15 & 10.2 & 2.8 \\
$\mathrm{MS}(\mathrm{cm})^{1}$ & 89.5 & 108 & 92.8 & 118.5 \\
Slope (\%) & 4 & 3 & 50 & 51 \\
Drainage Class $^{2}$ & SWPD & SWPD/PD & WD & WD \\
\hline
\end{tabular}

${ }^{\mathrm{T}} \mathrm{O}$ horizon and MS thicknesses were not significantly different at $\mathrm{p}<0.05$

${ }^{2} \mathrm{WD}=$ well drained, $\mathrm{SWPD}=$ somewhat poorly drained, $\mathrm{PD}=$ poorly drained.

All three soils were originally described as having cambic horizons, but after laboratory texture analysis, it was found that each of these soils had enough clay increase in the illuvial horizons to be considered argillic. The field soil scientist who described and sampled the pedons indicated that each of these soils had arguable clay films and 
argillic horizons although they were border-line argillic. Also, these soils were developing in acidic Pottsville sandstone which has led to sandier soil textures (sandy loam, sandy clay loam). The lessivage process is not usually as active in soils with low weatherable mineral contents because there is less clay to move through the profile (Buol et al., 1997). These factors probably contributed to the difficulty in the clay film determination in the field.

\section{Ridgetops}

Four of the soils sampled in this study were located on the ridgetop positions (descriptions found in Appendix A). These soils developed in colluvium from Pottsville sandstone and shale. According to the geology map (Figure 2) site R3 formed in geologic material of the Allegheny Formation. However, the field soil scientist thought the soil formed from Pottsville geology, and he doubted that any Allegheny Formation material was present in this area.

It was initially assumed that these soils were forming in residuum, as one would expect on ridgetops. However, the field soil scientist believed that these ridgetops were very old land formations, whereby, through many years of weathering, the surrounding mountains had eroded away leaving what are now the high, flat ridgetops of colluvium that exist there today.

These soils had the highest elevations of any pedons in this study, ranging from $1110 \mathrm{~m}$ to $1190 \mathrm{~m}$, with slopes of $1 \%$ to $4 \%$ (Table 2). The vegetation on these soils was mainly hardwood species, with some intermixed spruce, hemlock and rhododendron (Appendix D, Table 39). Each of these soils was deeper than $150 \mathrm{~cm}$ to bedrock and 
were either somewhat poorly or poorly drained. Average mineral solum thickness was $108 \mathrm{~cm}$ (Table 2).

The organic layers varied greatly at these sites. All ridgetop soils had Oi horizons, two had an Oe, and three had at least one Oa. There was a wide range of organic matter thickness. Two of the soils had a 3-cm thick organic layer (R1 and R2), $\mathrm{R} 4$ had a $12-\mathrm{cm}$ thick organic layer, and R3 had an organic layer that was $42 \mathrm{~cm}$ thick. Site R3 was covered with huge flags of sandstone and shale and was believed to have had frost-wedge/heave action from periglacial activity (Tony Jenkins, NRCS soil scientist, personal communication). Two sites contained E horizons (R3 and R4), while two did not (R1 and R2). Those soils with $\mathrm{E}$ horizons had $\mathrm{O}$ horizons above the $\mathrm{E}$, but no $\mathrm{A}$ horizons.

Fragipans existed in all $\mathrm{R}$ soils. This is an unusual feature of ridgetop soils because generally, these soils form in residuum, and fragipans normally do not develop as readily in residual material as in other parent materials. However, as stated earlier, these are colluvial soils. The drainage classes (somewhat poorly drained) at these sites were indicative of soils with fragipans with the highest degree of fragipan expression (Ciolkosz, 1992). Redoximorphic features were found in every pedon and three of the four soils exhibited gleyed horizons. Gleyed prism faces are typical of soils with fragipans (Ciolkosz, 1992), as they act as an impeding layer, restricting water movement, and causing the "water table" to rise higher in the profile than it normally would without such a layer.

All ridgetop soils had cambic horizons except for R3. This soil was originally described in the field as having a cambic horizon, however, upon analyzing laboratory 
texture data in conjunction with the mention of "few clay films" on the field report, it was decided that this pedon had an argillic horizon. Because of the sandy nature of the parent material, along with impeded water movement, it makes sense that most of these soils had cambic horizons.

A thin Bh horizon with spodic character was described in soils R4. This pedon was developing in the proper environment for such a layer to form. It had a sandy parent material, was very acidic, was supporting acid loving vegetation, had an established organic layer, and had a sandy loam/ loam texture throughout.

\section{Sideslopes}

For discussion purposes, the sideslope soils were divided into two categories: those with cambic horizons and those with argillic horizons. There were three pedons for each of the sideslope categories.

\section{Sideslope-cambic}

Sideslope soils with cambic horizons had various bedrock geologies (descriptions found in Appendix A). Two of the pedons were formed above Pottsville sandstone, one from the Kanawha Formation (SSC1) and the other from the New River Formation (SSC3) (Fig. 2). The third soil, SSC2, was located over Mauch Chunk geology (Fig. 2). All sites were located on extremely steep slopes, ranging from $38 \%$ to 68\% (Table 2), and were developing in colluvium. The vegetation on these sites was deciduous, consisting mainly of beech, birch, and red maple (Table 39). Site SSC1 had very poor vegetation, but this was not unusual for the south-facing slopes of the area. The other 
two sites had northeast aspects. Elevation varied considerably, with the lowest site around $670 \mathrm{~m}$ and the highest altitude at about $1010 \mathrm{~m}$. Each site was well drained and had considerable rock fragment percentages throughout the profile. For these soils, the average mineral solum thickness was $92.8 \mathrm{~cm}$ (Table 2). Depth of these soils ranged from $99 \mathrm{~cm}$ where bedrock was hit to over $170 \mathrm{~cm}$ where bedrock was still not present (Appendix A).

All three pedons had organic layers. Two of the soils (SSC1 and SSC3) had well established organic horizons, containing Oi, Oe, and Oa layers, whereas the third soil (SSC2) only had Oi layers. This pedon (SSC2) was the steepest of the three and it also was forming on completely different geology, the Mauch Chuck. This lack of organic matter development was also noticed on the sideslope soils with argillic horizons, and they also were developing on the Mauch Chunk geology. Total thickness of the organic horizons ranged from $2.5 \mathrm{~cm}$ to $15 \mathrm{~cm}$.

None of these soils included E horizons; however, pedon SSC1 had an A/E and a BE described. These sites were very steep which probably resulted in high run-off and little infiltration, not allowing for adequate flow through the profile to develop $\mathrm{E}$ horizons.

One pedon (SSC2) was initially designated as having an argillic horizon. It was determined, after examination of laboratory particle size data, that this soil did not have enough accumulation of clay in its illuvial layers to be considered argillic and was designated as having a cambic horizon. 


\section{Sideslope-argillic}

Each of the sideslope soils with argillic horizons formed in colluvium from Mauch Chunk geology, which consists mainly of shale and mudstone. Like the sideslope cambic soils, these soils occur on very steep slopes, ranging from $44 \%$ to $59 \%$ (Table 2 ). These sites are supporting the most diverse vegetation, comprised mostly of hardwood, deciduous species (Appendix D, Table 39). The aspects varied from $\mathrm{N}$ to $\mathrm{E}$ to $\mathrm{SW}$, while elevations ranged from $650 \mathrm{~m}$ to $847 \mathrm{~m}$. Depth varied from $101 \mathrm{~cm}$ where bedrock was found to greater than $160 \mathrm{~cm}$ (and no bedrock) (Appendix A), with all sites being well drained. Average mineral solum thickness at these sites was $188.5 \mathrm{~cm}$ (Table 2). Rock fragments were found throughout the pedons, but compared to the other sideslope soils, the percentages were far less (20 to $30 \%$ throughout).

There was very little organic horizon development at these sites, with no soil having more than an Oi horizon. These soils could have been truncated at some point due to a logging event, however, most logging that took place in Otter Creek occurred around the same time throughout the wilderness. The organic layers for these soils were all between 2 and $3 \mathrm{~cm}$.

\section{PHYSICAL, CHEMICAL, AND MINERALOGICAL PROPERTIES}

\section{Bulk Density}

The bulk density $(\mathrm{Db})$ of all soils in the study ranged from $0.1 \mathrm{Mg} \mathrm{m}^{-3}$ in the organic horizons to $1.9 \mathrm{Mg} \mathrm{m}^{-3}$ in the mineral horizons (Fig.3). Jenkins (2001) found similar results, with $\mathrm{Db}$ varying from $0.1 \mathrm{Mg} \mathrm{m}^{-3}$ in the $\mathrm{O}$ horizons to $2.06 \mathrm{Mg} \mathrm{m}^{-3}$ in the 
mineral horizons. Generally, bulk density increased with depth, with average $\mathrm{Db}$ equaling $0.2 \mathrm{Mg} \mathrm{m}^{-3}$ in the $\mathrm{O}, 0.8 \mathrm{Mg} \mathrm{m}^{-3}$ in the $\mathrm{A}, 1.6 \mathrm{Mg} \mathrm{m}^{-3}$ in the $\mathrm{B}$, and $1.7 \mathrm{Mg} \mathrm{m}^{-3}$ in the $\mathrm{C}$ horizon. Landscape position did not account for any apparent differences in $\mathrm{Db}$, except for in B horizons. Bulk density for B horizons ranged from $1.2 \mathrm{Mg} \mathrm{m}^{-3}$ for soils occurring on SSC, $1.6 \mathrm{Mg} \mathrm{m}^{-3}$ for SSA and T soils, to $1.8 \mathrm{Mg} \mathrm{m}^{-3}$ for those soils located on the $\mathrm{R}$ position. The higher $\mathrm{Db}$ values for the $\mathrm{R}$ were attributed to the fragipan layer that was present in each of these soils. Statistical analyses indicated that R soils had significantly higher B horizon bulk density than the SSC soils, but there were no differences among any other horizons.

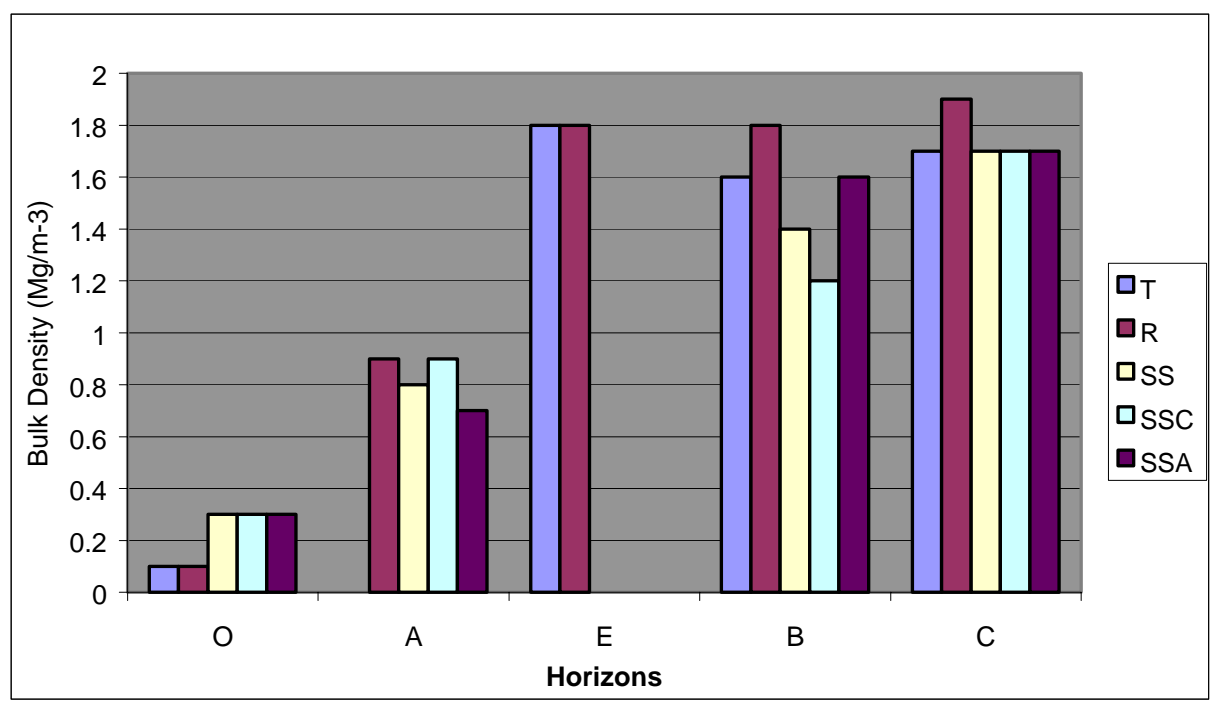

Figure 3. Average bulk density of Otter Creek soils on different landscape positions (missing data for $\mathrm{Db}$ for A horizon of $\mathrm{T}$ soils).

\section{Percent clay}

Clay contents increased from the A to the B horizon for R and SSA soils, and decreased slightly for T and SSC soils. All soils experienced a clay decrease from the B to the $\mathrm{C}$ horizon (Table 3) except $\mathrm{R}$ soils, which had a dramatic increase in clay from the 
B to the C horizon. E horizons had the lowest clay content, as would be expected.

Sideslope cambic soils had the lowest clay values and this was attributed to slope steepness and the geology not being conducive to clay generation.

Table 3. Clay percentages of soil horizons across landscape positions

\begin{tabular}{ccccc}
$\begin{array}{c}\text { Landscape } \\
\text { Position }\end{array}$ & A & E & B & C \\
\hline Terrace & 22.9 & 9.5 & 22.2 & $20.2 \mathrm{ab}^{1}$ \\
Ridgetop & 19.8 & 9.3 & 21.9 & $32.0 \mathrm{a}$ \\
Sideslope & 15.1 & ------ & 18.4 & $12.2 \mathrm{ab}$ \\
Sideslope-Cambic & 16.8 & ----- & 15.5 & $5.6 \mathrm{~b}$ \\
Sideslope-Argillic & 13.5 & ------ & 21.4 & $18.9 \mathrm{ab}$ \\
\hline
\end{tabular}

${ }^{1} \mathrm{C}$ hroizon values followed by the same letter are not significantly different at $\mathrm{p}<0.05$. Values for A and B horizons were not significantly different.

\section{Percent Carbon}

Soils in the Otter Creek Wilderness had typical carbon patterns, with carbon being the highest in the $\mathrm{O}$ horizons and steadily decreasing throughout the profile. Organic carbon values ranged from 38.1 to $44.5 \%$ in O horizons (Table 4). Data from Jenkins (2001) showed a wider variation in carbon values of $\mathrm{O}$ horizons in other soils from the same area with a low of $27.9 \%$ and a high of $51.9 \%$. In the mineral horizons, carbon varied from $8.2 \%$ in an A horizon to $0.3 \%$ in a $\mathrm{C}$ horizon. These values were similar to the findings of Jenkins (2001). Ridgetop and T soils had higher carbon values in their A 
horizons than did the SS soils. This was to be expected, considering R and T soils were wetter (poorly drained and somewhat poorly drained) than the SS soils (all well drained).

Table 4. Average percent carbon for horizons across landscape position for soils in the Otter Creek Wilderness.

\begin{tabular}{cccccc}
\hline $\begin{array}{c}\text { Landscape } \\
\text { Position }\end{array}$ & O & A & E & B & C \\
\hline Terrace & 39.6 & 8.1 & 0.9 & 1.0 & $0.6 \mathrm{ab}^{1}$ \\
Ridgetop & 38.1 & 8.2 & 0.7 & 2.0 & $0.8 \mathrm{ab}$ \\
$\begin{array}{c}\text { Sideslope- } \\
\text { Cambic }\end{array}$ & 44.5 & 5.3 & ----- & 1.7 & $1.3 \mathrm{a}$ \\
$\begin{array}{c}\text { Sideslope- } \\
\text { Argillic }\end{array}$ & 38.3 & 6.1 & ----- & 0.8 & $0.3 \mathrm{~b}$
\end{tabular}

${ }^{\mathrm{T}} \mathrm{C}$ hroizon values followed by same letter are not significantly different at $\mathrm{p}<0.05$. Values for other horizons are not significantly different.

Soil organic carbon (SOC) stocks were similar to other soils in this region, and comparable to other forested soils throughout the U.S. When averaged among landscape position, SSA soils had the lowest SOC values at $13.5 \mathrm{~kg} \mathrm{~m}^{-2}$ and SSC soils were the highest at $20.4 \mathrm{~kg} \mathrm{~m}^{-2}$, however no statistical differences were found between any of the landscape positions (Table 5).

Table 5. Carbon stocks for whole soils.

\begin{tabular}{cc}
\hline $\begin{array}{c}\text { Landscape } \\
\text { Position }\end{array}$ & $\begin{array}{c}\text { Carbon } \\
\left(\mathbf{k g ~ m}^{-2}\right)\end{array}$ \\
\hline Terrace & $16.7 \mathrm{a}^{1}$ \\
Ridgetop & $14.5 \mathrm{a}$ \\
$\begin{array}{c}\text { Sideslope- } \\
\text { Cambic } \\
\text { Sideslope- } \\
\text { Argillic }\end{array}$ & $20.4 \mathrm{a}$ \\
& $13.5 \mathrm{a}$ \\
\hline Values followed by the same letter \\
are not significantly differnet at $\mathrm{p}<0.05$.
\end{tabular}


Jenkins' (2001) study showed SOC pools that varied from 11.3 to $18.8 \mathrm{~kg} \mathrm{~m}^{-2}$ for frigid spodosols and inceptisols, while SOC of mesic ultisols ranged from 8.9 to $11.7 \mathrm{~kg}$ $\mathrm{m}^{-2}$. Although similar to my results, Jenkins values are slightly lower. Jenkins found that the method of determining bulk density greatly affected SOC results, with the generally practiced clod method overestimating bulk density, especially in upper horizons. In both Jenkins's study and this study, the frame method was used for all $\mathrm{O}$ and some A horizons, while the clod method was used for all other subsurface horizons. In a study of soils in the Lake States, Grigal and Ohman (1992) found C storage ranging from $13.9 \mathrm{~kg} \mathrm{~m}^{-2}$ in jack pine (Pinus banksiana) forested areas to $23.4 \mathrm{~kg} \mathrm{~m}^{-2}$ in regions occupied by hardwood species. They found that for mineral soils, areas with more precipitation and higher clay contents had greater $\mathrm{C}$ incorporation. These trends were not found in the soils of Otter Creek. They also considered tree species as a major factor in C sequestration, with deciduous trees having the highest SOC pools.

\section{Soil pH}

Average $\mathrm{pH}$ values for Otter Creek soils ranged from 3.3 to 5.6 (Fig. 4). It appears that SSA had slightly higher $\mathrm{pH}$ values than soils occurring on other landscapes. This was probably due to the formation of these soils on the Mauch Chunk geology and not the acidic Pottsville sandstone. The soil $\mathrm{pH}$ was reflected in the vegetation at these sites. Areas having higher $\mathrm{pH}$ values were producing hardwood species, whereas the most acidic soils, those occurring on the terraces supported more acid loving vegetation, such as hemlock, spruce, and rhododendron. 


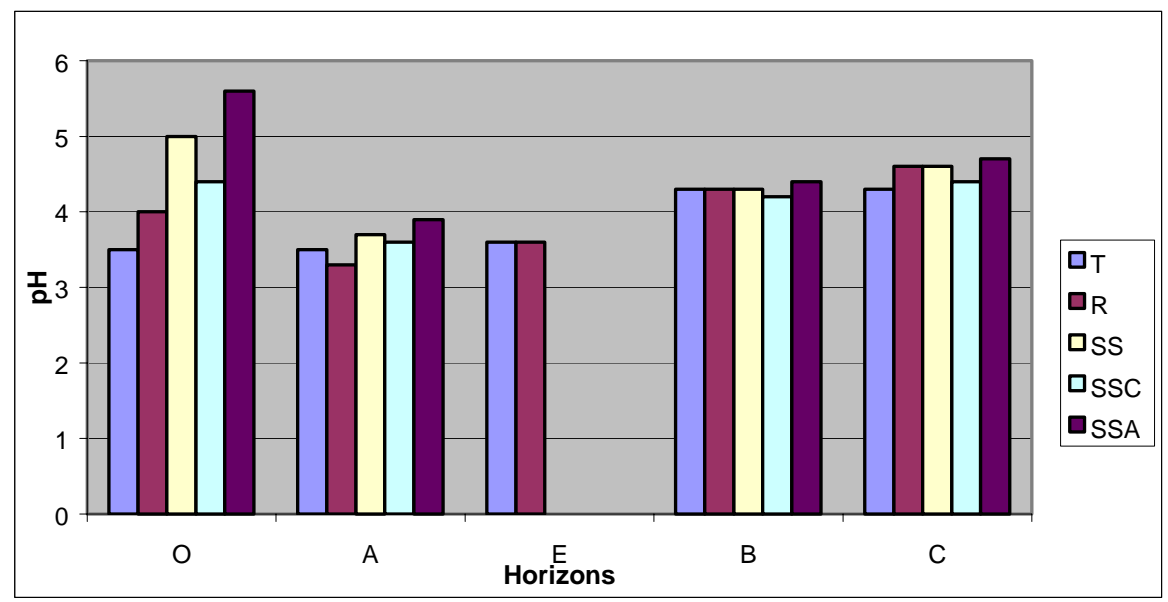

Figure 4. Average $\mathrm{pH}$ values of soil horizons in Otter Creek across various landscapes.

\section{Calcium and Aluminum}

Determining calcium and aluminum in forest soils is important because of the general acidic nature of these soil ecosystems. In conjunction with the natural acidifying processes of forest soils, acidic deposition can increase leaching of $\mathrm{Ca}^{+2}$ and thereby reduce its availability. Calcium deficiencies can become prevalent which can ultimately be detrimental to productivity. In tandem with this reduction in calcium, $\mathrm{Al}$ increases, which can cause $\mathrm{Al}$ toxicity and compound productivity threats posed by soil nutrient deficiencies (Huntington, 2000; Lyon and Sharpe, 1999).

Overall, terrace soils were found to have the lowest exchangeable $\mathrm{Ca}$ concentrations (Fig. 5). These soils were the most acidic and had the lowest percent base saturation. This agreed with work done by Adams et al. (2000) where they stated that soils most sensitive to a decline in forest productivity due to base cation depletion were those developing on acidic parent material with low percent base saturation and $\mathrm{pH}$ values less than 4.5. The SSA soils on the other hand had the highest exchangeable 


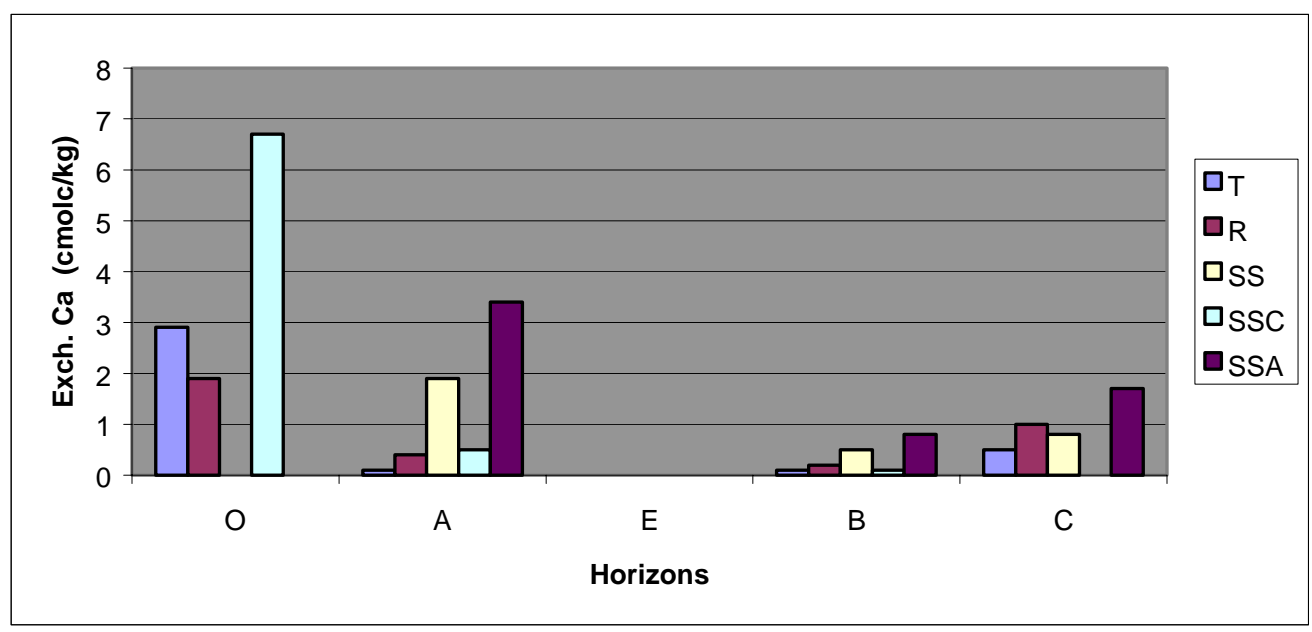

Figure 5. Average exchangeable calcium concentrations of forest soil horizons in the Otter Creek Wilderness.

calcium concentrations (Fig. 5) and developed on less acidic parent material and had the highest percent base saturation.

For all soils in this study, average exchangeable Ca ranged from trace amounts in the E horizons to $6.7 \mathrm{cmol}_{\mathrm{d}} / \mathrm{kg}$ in the SSC organic layer (Fig 5). Among the various horizons, the organic and A horizons had the overall highest concentrations of calcium (averaging $3.8 \mathrm{cmol}_{\mathrm{C}} / \mathrm{kg}$ and $1.1 \mathrm{cmol}_{\mathrm{C}} / \mathrm{kg}$, respectively). This was attributed to biocycling of the organic matter, in addition to the calcium that was stored in the organic horizons being leached more slowly than in the mineral horizons (Lyon and Sharpe, 1999). In a Pennsylvania forest soil study, Lyon and Sharpe (1999) recognized that the relatively high $\mathrm{Ca}$ levels noticed in $\mathrm{O}$ horizons was attributed to the decomposition of litter that had a relatively high $\mathrm{Ca}$ content. The lowest average $\mathrm{Ca}$ values were found in the $\mathrm{E}$ and $\mathrm{B}$ horizons (trace levels and $0.3 \mathrm{cmol}_{\mathrm{c}} / \mathrm{kg}$, respectively) because of a decrease in organic matter in conjunction with these horizons being more highly weathered. Huntington et al. (2000) also reported higher exchangeable Ca values in the A horizons of their 
Piedmont forest soils compared with the B and E layers, with the E horizons having the lowest concentrations. Calcium content in their soils ranged from $0.22 \mathrm{cmol}_{c} / \mathrm{kg}$ in the $\mathrm{E}$ horizons to $3.2 \mathrm{cmol}_{\mathrm{c}} / \mathrm{kg}$ in the A horizons. These values were slightly higher than the concentrations that were found in the Otter Creek soils. The higher Ca observed in the Piedmont study could be a consequence of the liming during the period of cultivation prior to afforestation. There was an increase of $\mathrm{Ca}$ in the $\mathrm{C}$ horizons (average of 0.8 $\mathrm{cmol}_{\mathrm{c}} \mathrm{kg}$ ) of the Otter Creek soils, probably due to the less weathered nature of this layer having reserves of weatherable minerals that could supply Ca to the soil. In a similar study, Jenkins (2001) noted that exchangeable Ca decreased with depth and did not increase in the substrata.

In general, extractable $\mathrm{Al}$ was highest in the A horizons (average of $8.7 \mathrm{cmol}_{\mathrm{c}} \mathrm{kg}$ ) for all soils and lowest in the $\mathrm{O}$ and $\mathrm{E}$ horizons (average of $2.4 \mathrm{cmol}_{\mathrm{c}} / \mathrm{kg}$ and 1.0 $\mathrm{cmol}_{\mathrm{c}} / \mathrm{kg}$, respectively) (Fig. 6). Lyon and Sharpe (1999) also reported their organic horizons contained the lowest levels of extractable $\mathrm{Al}$ when compared to other horizons. This was expected because $\mathrm{Al}$ is typically complexed with organic compounds in solution and solid phase organic matter has the compacity to complex both monomeric and polymeric $\mathrm{Al}$, making $\mathrm{Al}$, for the most part, unavailable as an exchangeable ion (Lyon and Sharpe, 1999). Trettin et al. (1999) found that Al concentration was higher in the B horizons than the A horizons in Tennessee forest soils. This would be expected if relating $\mathrm{Al}$ concentration to a decrease in organic matter (more $\mathrm{Al}$ is available because there is less organic matter to retain it), however, soils in this study had higher Al levels in the A horizons (average of $8.7 \mathrm{cmol}_{\mathrm{c}} / \mathrm{kg}$ ) compared with the B (average of 5.3 $\mathrm{cmol}_{\mathrm{d}} \mathrm{kg}$ ). Furthermore, $\mathrm{pH}$ values were less in the A horizons than in the $\mathrm{B}$ horizons 


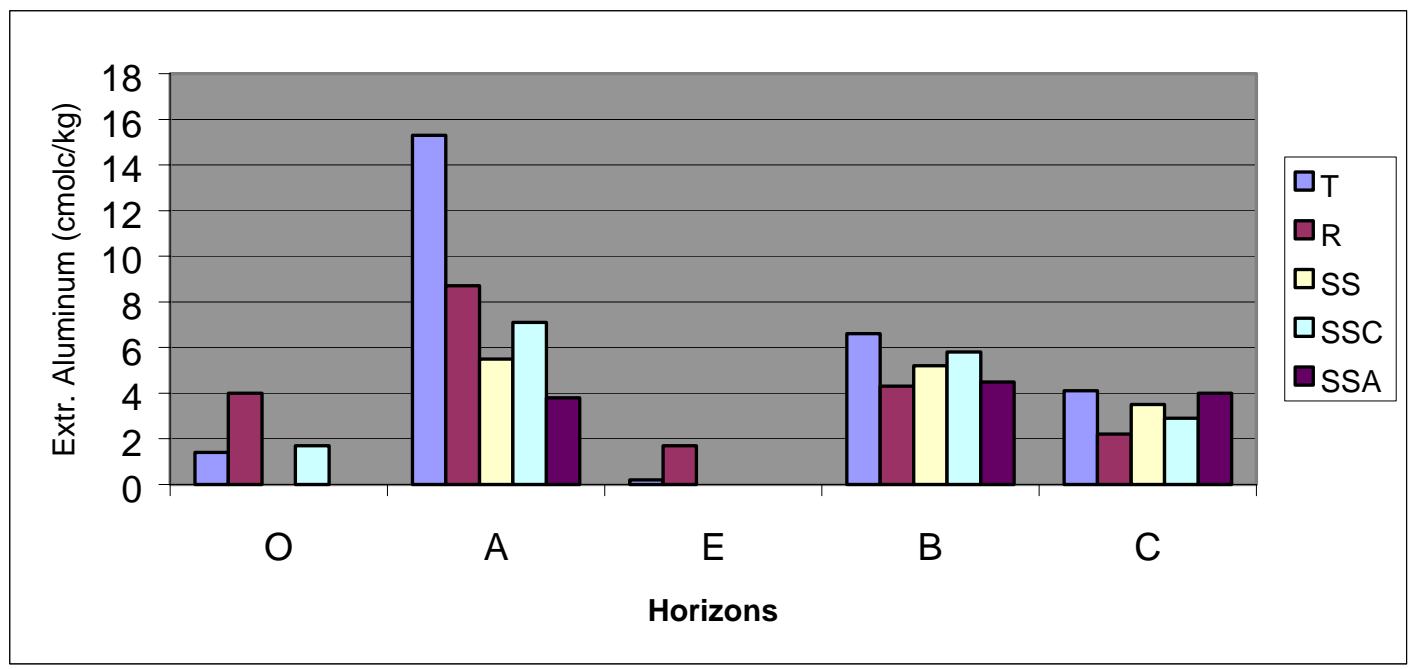

Figure 6. Extractable aluminum of forest soil horizons in Otter Creek across various landscape positions.

(Fig. 4), and as $\mathrm{pH}$ decreased, $\mathrm{Al}$ increased and adsorption of $\mathrm{Al}$ to clay surfaces will decrease CEC.

Molar Ca:Al ratios have been suggested as an indicator of potential nutritional stress because of the damaging effects of escalated Al levels on root proliferation and on base cation uptake and nutrition (primarily Ca) (Cronan and Grigal, 1995; Lyon and Sharpe, 1999; Jenkins, 2000; Schoenholtz et al., 2000). Cronan and Grigal (1995) established that if the molar $\mathrm{Ca}: \mathrm{Al}$ ratio fell below 1, then there was potential for adverse effects to forest physiological functions. They were even more specific and developed further risk of $\mathrm{Al}$ stress criteria based on the value of the $\mathrm{Ca}: \mathrm{Al}$ ratio in soil solution: $<1$ (50\% risk): $<0.5$ (75\% risk): and $<0.2(95-100 \%$ risk). This ratio was calculated for the Otter Creek soils across the various landscape positions and is represented in Figure 7. All soils fell below the initial threshold of 1 , indicating that every soil in this study was at risk for possible detrimental effects due to Al toxicity. The SSA soils were the only ones 


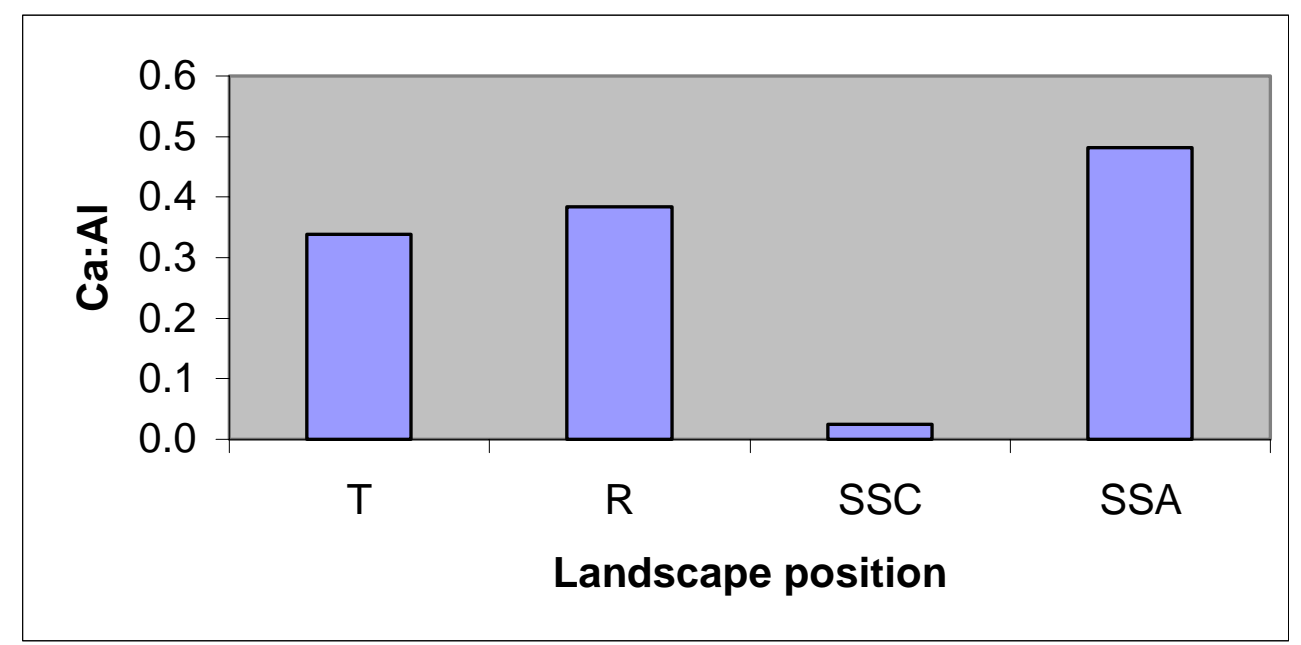

Figure 7. Ca:Al molar ratio of Otter Creek soils spanning different landscape positions.

in the $50 \%$ risk category, $\mathrm{T}$ and $\mathrm{R}$ soils were at a $75 \%$ risk, while $\mathrm{SSC}$ soils were at a 95 $100 \%$ risk of adverse effects from an imbalance of $\mathrm{Ca}$ and $\mathrm{Al}$.

\section{Cation Exchange Capacity}

Cation exchange capacity (CEC) via summation was generally slightly higher than the ammonium acetate-Kjeldhal method, but trends were similar (Table 6). Since the summation method was used for classification, it was chosen to represent the CEC values for comparison purposes. This property is of concern because soils with low CEC values are susceptible to acidification and base cation leaching and indicate that the soil has a low buffering capacity. Cation exchange capacity decreased throughout the profile, with the highest values appearing in the organic layers, followed by the A horizons (Fig. 8). Landscape position did not appear to make any difference in the cation exchange capacity of the soils. Average CEC values ranged from $7.2 \mathrm{cmol}_{\mathcal{C}} / \mathrm{kg}$ in the highly weathered $\mathrm{E}$ horizons to $113 \mathrm{cmol}_{\mathrm{c}} / \mathrm{kg}$ in the nutrient-rich organic layers (Fig. 8). 
Table 6. Cation exchange capacity (CEC) and effective cation exchange capacity (ECEC) of horizons across landscape positions.

\begin{tabular}{llccccc}
\hline & Horizon & T & R & SS & SSC & SSA \\
\hline O & CEC (sum) & 113.0 & 72.1 & 103.5 & 103.5 & N/A \\
& CEC (pH 7) & 94.8 & 60.1 & 109.3 & 109.3 & N/A \\
& ECEC & 5.6 & 6.7 & 9.9 & 9.9 & N/A \\
\hline A & CEC (sum) & 50.0 & 39.1 & 27.6 & 25.3 & 29.9 \\
& CEC (pH 7) & 36.3 & 68.9 & 23.0 & 22.5 & 23.5 \\
& ECEC & 15.7 & 9.5 & 8.0 & 7.8 & 8.2 \\
\hline E & CEC (sum) & 13.0 & 7.2 & N/A & N/A & N/A \\
& CEC (pH 7) & 8.2 & 4.5 & N/A & N/A & N/A \\
& ECEC & 4.2 & 1.7 & N/A & N/A & N/A \\
\hline B & CEC (sum) & 18.7 & 15.0 & 17.1 & 20.3 & 13.9 \\
& CEC (pH 7) & 12.0 & 11.3 & 14.0 & 17.7 & 10.3 \\
& ECEC & 6.9 & 4.7 & 5.9 & 5.9 & 5.9 \\
\hline C & CEC (sum) & 12.7 & 10.7 & 12.3 & 11.9 & 12.6 \\
& CEC (pH 7) & 8.0 & 8.5 & 9.3 & 8.2 & 10.3 \\
& ECEC & 5.0 & 4.3 & 5.0 & 2.9 & 7.0 \\
\hline
\end{tabular}

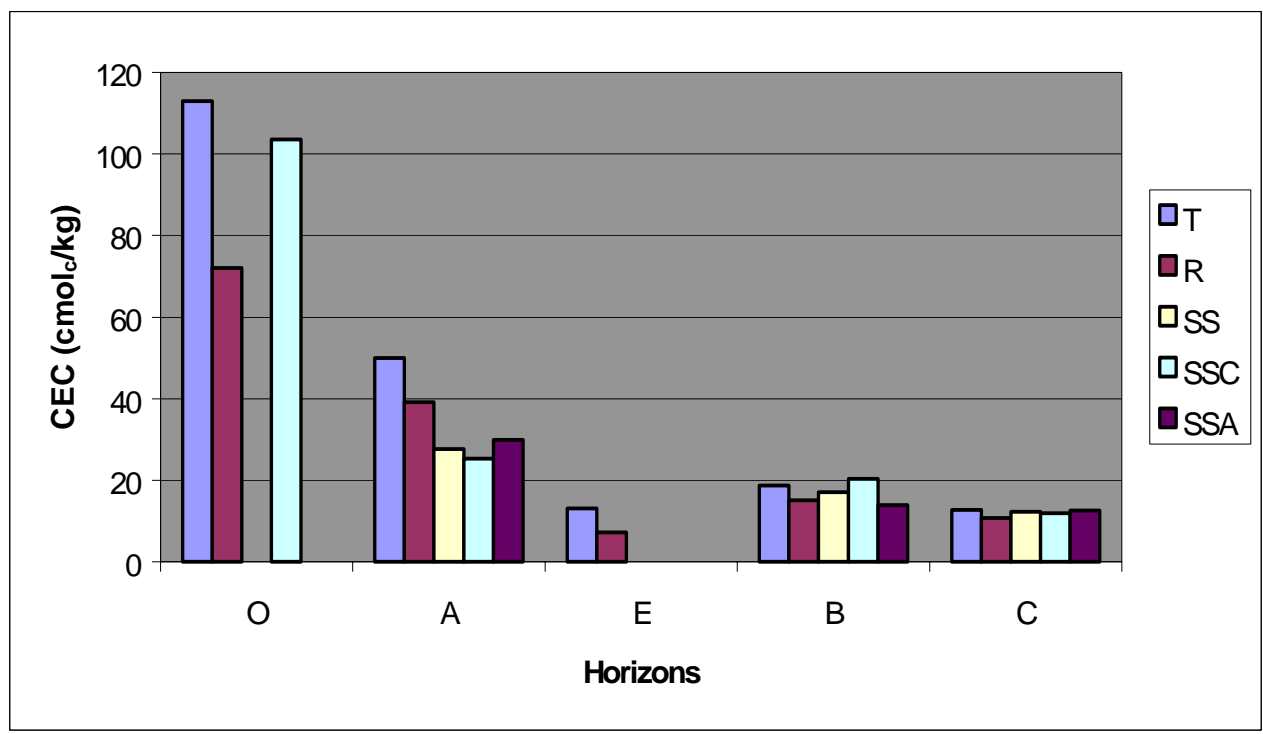

Figure 8. Cation exchange capacity (via summation) of soils in the Otter Creek Wilderness 
Effective cation exchange capacity (ECEC) also was calculated for the soils of Otter Creek (Table 6) and followed the pattern of CEC, decreasing with depth throughout the mineral solum (excluding E horizons, which had the lowest ECEC values), however, ECEC increased slightly in the C horizon of SSA soils. Across landscape positions, ECEC was highest in T soils (average $7.5 \mathrm{cmol}_{\mathrm{c}} \mathrm{kg}^{-1}$ ) and lowest in R soils (5.4 $\left.\mathrm{cmol}_{\mathrm{c}} \mathrm{kg}^{-1}\right)$. The higher value for the $\mathrm{T}$ soils was attributed to escalated $\mathrm{Al}$ in the $\mathrm{A}$ horizon giving rise to higher ECEC.

\section{Base Saturation}

Base saturation of SSA soils A+E horizons was significantly higher $(\mathrm{p}<0.05)$ than base saturation of $\mathrm{A}+\mathrm{E}$ horizons on other landscape positions. There were no significant differences among landscape positions for any other horizons. Base saturation for SSC and $\mathrm{T}$ soils were very low, with the average $\mathrm{BS}$ within the major mineral horizons being less than $2 \%$ and $4 \%$, respectively (Fig. 9). This was probably due to these soils having the highest extractable acidity and $\mathrm{Al}$ (Fig. 6) values, as well as, the lowest exchangeable Ca concentrations (Fig 5). The SSA soils had the highest BS, with the average among the mineral horizons being $15.8 \%$. The higher values in these soils were attributed to the parent material for these pedons. The Mauch Chunk geology produced clay-rich soils capable of retaining the cations giving rise to higher base saturation levels. Ridgetop had an average of $6.7 \%$ BS throughout the mineral layers. E horizons for R soils had only a trace amount of extractable bases, therefore, \%BS was negligible. 


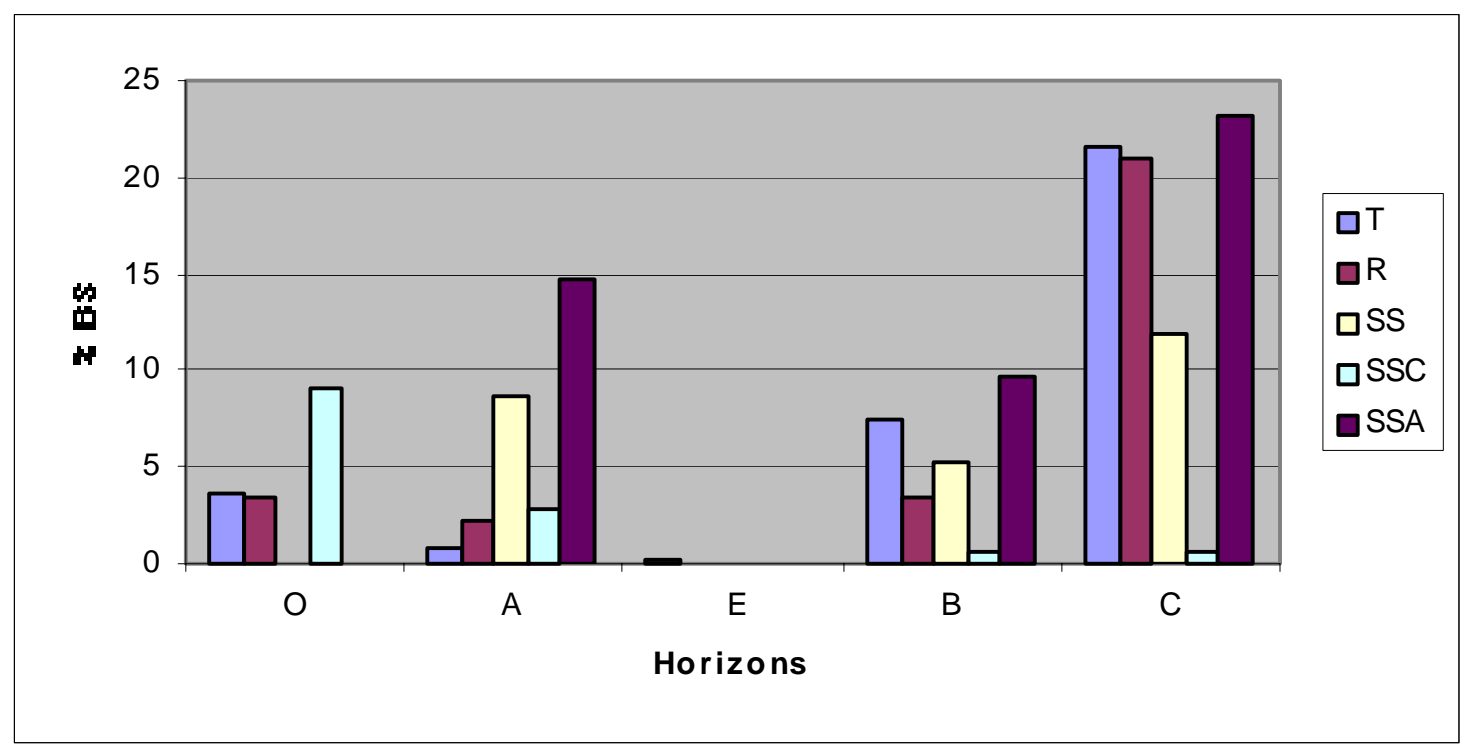

Figure 9. Average percent base saturation of horizons for Otter Creek soils across different landscape positions.

In addition to BS acting as a relative indicator of nutrient status in acid soils, it may also indicate acid toxicity risks to fine roots and mycorrhizal fungi in the organic layers of forest soils. Meiwes et al. (1986) developed three threshold levels to indicate these risks. They were: high $(\mathrm{BS}<5 \%)$, medium (BS between $5-10 \%$ ), and low (BS $>10 \%)$ in the organic horizons. No soils were in the low risk group. Figure 9 shows that only organic horizons of SSC soils were in the medium risk category, while T and R soils were both at a high risk for damaging fine roots and mychorrizal fungi due to acid toxicity. The SSA soils had no organic horizons except Oi's which were not analyzed.

Another assessment of whether a soil was at risk of potential Al stress and/or acid soil infertility involved determining the base saturation of the effective cation exchange capacity (BSECEC). Cronan and Grigal (1995) proposed that if the BSECEC was less than $15 \%$, then the soil would be at risk for Al toxicity and acid soil infertility. In the 
mineral solum, all soils in this study were below this threshold, except for argillic soils occurring on sideslopes (Table 7). This was due to the SSA soils having a greater supply of exchangeable bases on their exchange sites. In a similar study in the same forested region, it was found that for most pedons, the BSECEC dropped below $15 \%$ within 20 $\mathrm{cm}$ of the surface (Jenkins, 2001). According to this indicator, all soils (excluding SSA soils) were in jeopardy of potential forest productivity decline.

Table 7. Percent base saturation of the effective cation exchange capacity of the mineral solum of soils across various landscape positions.

\begin{tabular}{cc}
\hline Landscape Position & BSECEC (\%) \\
\hline Terrace & 5.9 \\
Ridgetop & 12.0 \\
Sideslope-Cambic & 6.4 \\
Sideslope--Argillic & 35.6 \\
\hline
\end{tabular}

\section{Clay Mineralogy}

$\mathrm{X}$-ray diffraction offers semiquantitative estimates, but is a useful method to identify the crystalline mineral components of the soil (Soil Survey Staff, 1996). It was decided to report clay mineralogy with respect to geology (Table 8) and not landscape position because of the strong influence geology has on the clay species found in the soil. The different geologies identified in this study include the New River and Kanawha Formations of the Pottsville group and the Mauch Chunk group. It needs to be noted that 
although the New River and Kanawha formations are part of the Pottsville group, some of Otter Creek was mapped simply as Pottsville with no formation associated with it, as was the case with pedon R3. It should also be pointed out that this was the same soil that was designated as the Allegheny Formation, however, as stated earlier, this geology is unlikely present in the area.

Individual data noting landscape position, horizon, and geology can be located in appendix E. Pedon SSC3, developing from the New River Formation, was not calculated into the averages because many of the clay species occurred as mixed-layer minerals, whereby the individual clay minerals were unidentifiable. This led to skewed percentages for those minerals that were recognized. Information for this soil can also be found in appendix E. The Pottsville category contained only one soil (R3) and therefore does not have an associated range.

Table 8. Average percentages and ranges of clay species found in Otter Creek soils with respect to geology.

\begin{tabular}{|c|c|c|c|c|c|c|c|}
\hline & & $\mathrm{n}$ & $\mathrm{V}$ & $\mathrm{K}$ & $\mathrm{T}$ & $\mathrm{L}$ & $\mathrm{Q}$ \\
\hline New River & $\begin{array}{l}\text { ave } \\
\text { range }\end{array}$ & 2 & $\begin{array}{c}50 \\
47-53\end{array}$ & $\begin{array}{c}28 \\
20-35\end{array}$ & $\begin{array}{c}2 \\
0-4\end{array}$ & $\begin{array}{c}11 \\
8-14\end{array}$ & $\begin{array}{c}10 \\
10-10\end{array}$ \\
\hline Kanawha & $\begin{array}{l}\text { ave } \\
\text { range }\end{array}$ & 5 & $\begin{array}{c}29 \\
0-52\end{array}$ & $\begin{array}{c}26 \\
18-41\end{array}$ & $\begin{array}{c}9 \\
6-18\end{array}$ & $\begin{array}{c}10 \\
0-22\end{array}$ & $\begin{array}{c}25 \\
11-48\end{array}$ \\
\hline Pottsville & & 1 & A & 35 & 22 & 11 & 29 \\
\hline Mauch Chunk & $\begin{array}{l}\text { ave } \\
\text { range }\end{array}$ & 4 & $\begin{array}{c}42 \\
35-51\end{array}$ & $\begin{array}{c}23 \\
21-26\end{array}$ & $\begin{array}{c}10 \\
8-14\end{array}$ & $\begin{array}{l}A \\
A\end{array}$ & $\begin{array}{c}26 \\
20-30\end{array}$ \\
\hline
\end{tabular}

$\mathrm{n}=$ number of samples, $\mathrm{V}=$ Vermiculite, $\mathrm{K}=$ Kaolinite, $\mathrm{I}=$ Illite, $\mathrm{L}=$ Lepidocrocite, $\mathrm{Q}=$ Quartz, and $\mathrm{A}=$ Absent.

Montmorillonite and chlorite were not detected in any of the soils. Vermiculite was found in the greatest abundance in all samples except for the Pottsville category 
where it was not detected (Table 8). This was similar to findings from Feldman et al. (1991) where vermiculite was found to dominate the clay fraction on the high elevation forest soils of the southern Appalachians. Kaolinite was the second most prevalent clay species. Illite was found in relatively small quantities in all samples, except for the Pottsville class where it made up $22 \%$ of the total clay mineralogy. Lepidocrocite, not actually a clay mineral, but an iron oxy hydroxide $(\mathrm{FeO}(\mathrm{OH}))$, was present in all samples except for soils occurring on the Mauch Chunk geology. For the New River and Kanawha soils, this mineral was more prevalent than illite. The presence of lepidocrocite in the T and R soils, and not the SS soils was probably due to the wetness of the $\mathrm{T}$ and $\mathrm{R}$ soils and not the geology. Schwertman (1988) found that high chroma mottled areas found in wet soils are composed primarily of the mineral lepidocrocite. Quartz dominated approximately $27 \%$ of the total clay fraction of all samples, excluding the New River geology, where it occupied only $10 \%$.

\section{CLASSIFICATION}

All pedons of this study were characterized and classified to the family level (Table 9)(Soil Survey Staff, 1999). There were three soil orders recognized: 6 Inceptisols, 6 Ultisols, and one Alfisol. All data used for classification of these soils may be found in appendices A, B, and C. 
Table 9. Soil Classifications

\section{Terraces}

- T1 Loamy-skeletal, mixed, active, mesic Typic Endoaquults

- T2 Loamy-skeletal, mixed, active, mesic Typic Endoaquults

- T3 Fine, mixed, active, mesic Aquic Haplohumults

\section{Ridge-tops}

- R1 Fine-loamy, mixed, superactive, frigid Aeric Fragiaquepts

- R2 Fine-loamy, mixed, semiactive, frigid Aquic Fragiudepts

- R3 Loamy-skeletal, mixed active, frigid Aquic Fragiudults

- R4 Loamy-skeletal, mixed, superactive, frigid Aeric Fragiaquepts

\section{Sideslope-Cambic}

- SSC1 Loamy-skeletal, mixed, superactive, mesic Typic Fragiudepts

- SSC2 Loamy-skeletal, mixed, superactive, mesic Humic Dystrudepts

- $\quad$ SSC3 Loamy-skeletal, mixed, superactive, mesic Typic Dystrudepts

\section{Sideslope-Argillic}

- SSA1 Fine-loamy, mixed, active, mesic Ultic Hapludalfs

- SSA2 Fine-silty, mixed, superactive, mesic Typic Hapludults

- SSA3 Fine-silty, mixed, active, mesic Typic Hapludults

\section{Terrace soils}

\section{Soil Order}

There were three soils occurring on the terrace/high floodplain landscape. Each soil was described in the field as having cambic horizons (Bg's or Bw's), however, laboratory data (Appendix B) show that each pedon had enough clay increase from the eluvial layer to the illuvial layer (in this case, greater than 1.2 times) for these horizons to be considered argillic. Field soil scientists mentioned "some arguable clay films observed" on the field description sheets, so these soils were considered to have Bt horizons (instead of Bw's) and were therefore classified accordingly (note: the profile 
descriptions in Appendix A reflect what the field soil scientists reported in the field and not what laboratory data and subsequent discussion with these scientitsts later proved). Each of these soils had less than $35 \%$ base saturation in the appropriate control section (deepest horizon to $180 \mathrm{~cm}$ ). These soils were therefore classified as Ultisols due to the prescence of argillic horizons and the low base saturation.

\section{Suborder, Great Group, and Subgroup}

Two of these soils (T1 and T2) had redoximorphic features appearing below the organic horizons. Pedon T1 had a gleyed mineral horizon 10-cm beneath the organic layer, while site T2 did not exhibit a gleyed horizon until about 50-cm below the organic layers. Due to the wetness of these soils, they were both classified as Typic Endoaquults. Pedon T3 contained high amounts of organic carbon throughout the profile and was classified as a Haplohumult (must have $0.9 \%$ or greater OC in upper $15 \mathrm{~cm}$ of argillic horizon). This soil also showed evidence of wetness in the control sectction via redoximorphic depletions and concentrations (although, it was the driest of the three) and therefore was placed in the Aquic subgroup of the Haplohumults.

\section{Family Classification}

Because the two Endoaquults (T1 and T2) had greater than $35 \%$ rock fragments in their control section (the argillic horizon), they were classified in the loamy-skeletal particle size class. There was no dominant mineral in these soils therefore they were in the mixed mineralogy class. The Haplohumult (T3) was classified as having a fine particle size class due to the high amounts of clay in this soil in conjuntion with the low 
presence of rock fragments. It also had mixed mineralogy. All terrace soils had an active CEC activity class (a ratio of CEC to clay between 0.4 and 0.6 ) and were located below $1088 \mathrm{~m}$ in elevation and therefore, had a mesic soil temperature regime (Carter and Ciolkosz, 1980).

\section{$\underline{\text { Ridgetop soils }}$}

\section{Soil Order}

All R soils had cambic horizons, except for R3, which had an argillic horizon. As with the soils found on the terraces, this upland argillic soil was originally described as having a cambic horizon. Laboratory data show, however, that this pedon's illuvial horizon had enough clay increase to be argillic. Again, there was mention of "a few clay films" on the field report, so the appropriate classification change was made. The argillic soil had less than $35 \%$ base saturation in the control section $(75 \mathrm{~cm}$ below the top to the fragipan) and therefore was classified as an Ultisol. The other three R soils (R1, R2, and R4) had cambic horizons and were classified as Inceptisols. Every soil occurring on a ridgetop had a fragipan.

Site R4 had a thin Bh horizon that was just thick enough to be deemed a spodic horizon $(10 \mathrm{~cm})$ and had other spodic properties, however, it was not recognized in classification due to a color discrepancy. In order to be considered a spodic horizon, the layer must be comprised of $85 \%$ or more spodic material. One of the criteria was a color of 5 YR or redder. This particular horizon did indeed have this color; however, it only made up $70 \%$ of the horizon, and therefore was not enough to warrant the classification of spodic. 


\section{Suborder, Great Group, and Subgroup}

Among the R soils, two were classified in a udic suborder because they were in a udic soil moisture regime: one udept (R2) and one udult (R3). The other two soils (R1 and R4) contained a gleyed horizon within $50 \mathrm{~cm}$ of the mineral surface and were classified in an aquic suborder (aquept). The Ultisol (R3) was initially classified as a humult because of the organic carbon content $(1.1 \%)$ in the upper $15 \mathrm{~cm}$ of the argillic horizon. The carbon value was determined via combustion and therefore was a "total C" value. In acidic soils, this number is generally synonymous with the organic $\mathrm{C}$ value. However, data from a previous study (Jenkins, 2001), showed that in mineral layers of forest soils, the total $\mathrm{C}$ value was often slightly higher (0.1 to $0.3 \%)$ than the organic $\mathrm{C}$ value. This soil had a total $\mathrm{C}$ value of $1.1 \%$ and the determining value was $0.9 \%$. Taking this into consideration, this soil was reclassified to portray the pedon's stronger characteristic - the fragipan. Therefore, all soils were classified into a Fragi- great group. The two Fragiaquepts (R1 and R4) belonged to the Aeric subgroup due to color specifications (due to wetness). The Fragiudept and the Fragiudult both had redoximorphic features (concentrations and/or depletions) high enough in the profile (within $30 \mathrm{~cm}$ from the beginning of the mineral horizon) to warrant a subgroup classification of aquic.

\section{Family Classification}

All ridgetop soils had $15 \%$ or more fine sand or coarser fragments in the fraction less than $75 \mathrm{~mm}$ in diameter and had 18 to $35 \%$ clay placing them in the fine-loamy 
particle size class. There was no dominant mineral in these soils and therefore each was classified in the mixed mineralogy class. There were varied CEC activity classes. Pedons R1 and R4 were both superactive, having a CEC to clay ratio greater than 0.6. The Ultisol (R3) was active (ratio between 0.4 and 0.6), while the Aquic Fragiudept (R2) was semiactive (ratio between 0.24 and 0.6 ). All soils were classified as frigid because they occurred at elevations above $1088 \mathrm{~m}$ (Carter and Ciolkosz, 1980).

\section{$\underline{\text { Sideslope soils }}$}

The soils occurring on the sideslope position have been divided into two categories - soils with cambic horizons and soils containing argillic horizons. There are three pedons in each of the two categories.

\section{Soil Order}

The three sideslope soils containing cambic horizons are all Inceptisols. One site (SSC2) was initially described as having an argillic horizon in the field, but after reviewing the laboratory particle size data, this pedon did not show sufficient clay increase to merit the inclusion of an argillic horizon. These horizons were subsequently classified as cambic and the horizon designations changed to Bw1 and Bw2.

Among the sideslope soils with argillic horizons, two (SSA2 and SSA3) had base saturations less than $35 \%$ in their lowest horizons and were classified as Ultisols. The third soil (SSA1) had a base saturation greater than $35 \%$ at its deepest horizon and was classified as an Alfisol. The Alfisol, though, appears to be weathering to an Ultisol, as observed by the subgroup of this soil (noted below). All three soils with argillic horizons 
were formed from colluvial material from the Mauch Chunk formation. This geology is comprised of shale and mudstone, which contributed to the abundance of clay in these soils.

\section{Suborder, Great Group, and Subgroup}

Each of the cambic sideslope soils had a udic soil moisture regime and was classified in the udic suborder. Two of these soils (SSC2 and SSC3) were classified as Dystrudepts because they did not meet the qualifying characteristics for any other Udept great group and had a low base saturation. The other pedon (SSC1) contained a fragipan and hence was classified as a Fragiudept. This soil and SSC3 were classified in Typic subgroups, while the other Dystrudept (SSC2) contained an umbric epipedon and was classified in the Humic great group.

All soils with argillic horizons located on a sideslope also were located in a udic soil moisture regime and were classified in the udic suborder. Site SSA3 was initially classified as a humult due to the presence of moderately high organic carbon (OC) values in the control section $(1.0 \%)$, however, these values were borderline (the determining value being $0.9 \%$ ) and barely qualified as humic. Again, using the work of Jenkins (2001) which showed that mineral horizons in forest soils usually have slightly lower OC values than total $\mathrm{C}$ values, this soil was classified in the lower $\mathrm{C}$ category. Each of these three soils was typical and classified in the Haplo- great group. The two Ultisols (SSA2 and SSA3) had a Typic subgroup, while the Alfisol (SSA1), having a low base saturation for this order, was classified in the Ultic subgroup. 


\section{Family Classification}

Each SSC soil had greater than $35 \%$ rock fragments in their control sections (between $25 \mathrm{~cm}$ and $100 \mathrm{~cm}$ below the mineral soil surface), had no dominant mineral, had a CEC/clay ratio greater than 0.6, and were below $1088 \mathrm{~m}$ (Carter and Ciolkosz, 1980). Therefore, all SSC soils had the same family classification-loamy-skeletal particle size class, mixed mineralogy, superactive CEC activity class, and a mesic soil temperature regime.

Two of the SSA soils (SSA2 and SSA3) had, in the fraction less than $75 \mathrm{~mm}$ in diameter, less than $15 \%$ particles of fine sand or coarser and 18 to $35 \%$ clay and hence, had a particle size class of fine-silty. The Alfisol (SSA1) also had between 18 and 35\% clay but had less than $15 \%$ particles of fine sand or coarser and was classified as fineloamy. No SSA soil had a dominant mineral and therefore, all had mixed mineralogy. All soils were below $1088 \mathrm{~m}$ and therefore in the mesic temperature regime (Carter and Ciolkosz, 1980). The CEC activity classes for SSA1 and SSA3 were active (CEC/clay ratio between 0.4 and 0.6 ), while the other Ultisol was superactive (CEC/clay ratio greater than 0.6).

\section{EXTRACTABLE SULFATE AND SULFATE ADSORPTION POTENTIAL}

Sulfate adsorption capacity is a major concern to the USFS, as well as others interested in forest management, especially in the northeastern U.S. where sulfate is the principal anion in acidic deposition. Knowing which soils are still capable of adsorbing sulfate is important because adsorption of sulfate by soils reduces the ionic strength of 
soil solutions and thus reduces the leaching of polyvalent nutrient cations (Mitchell, et al., 1992; Fuller et al., 1985). The converse is also true: soils that are no longer adsorbing sulfate, sulfate saturated soils, are more susceptible to cation leaching (Harrison et al., 1989). Some factors affecting sulfate adsorption include $\mathrm{pH}$, organic matter content, clay content, extractable sulfate, and soil texture (Adams et al., 2000; Prenzel and Meiwes, 1994; Mitchell et al.,1992; MacDonald and Hart, 1990).

Average sulfate adsorption potential was calculated for all of the Otter Creek soils (Fig. 10). What was being evaluated was the soil's ability to adsorb any additional sulfate on top of what was already there. Any negative values, those that fell below the 0-line, indicated that sulfate was being released into the system. Positive values showed that these horizons were capable of accepting sulfate. All A and E horizons were sulfate saturated and released sulfate upon equilibration. This agreed with data from MacDonald and Hart (1990). Using the same experimental procedure, they found all A horizons and some E horizons of Michigan forest soils also released sulfate into the soil system. Many studies suggest that this is due to high organic matter content in the A horizons masking the adsorption sites, and the coarse-textured nature of the E horizons not being conducive to adsorption (MacDonald and Hart, 1990; Mitchell et al., 1992; Adams et al., 2000; Fuller et al., 1985). 


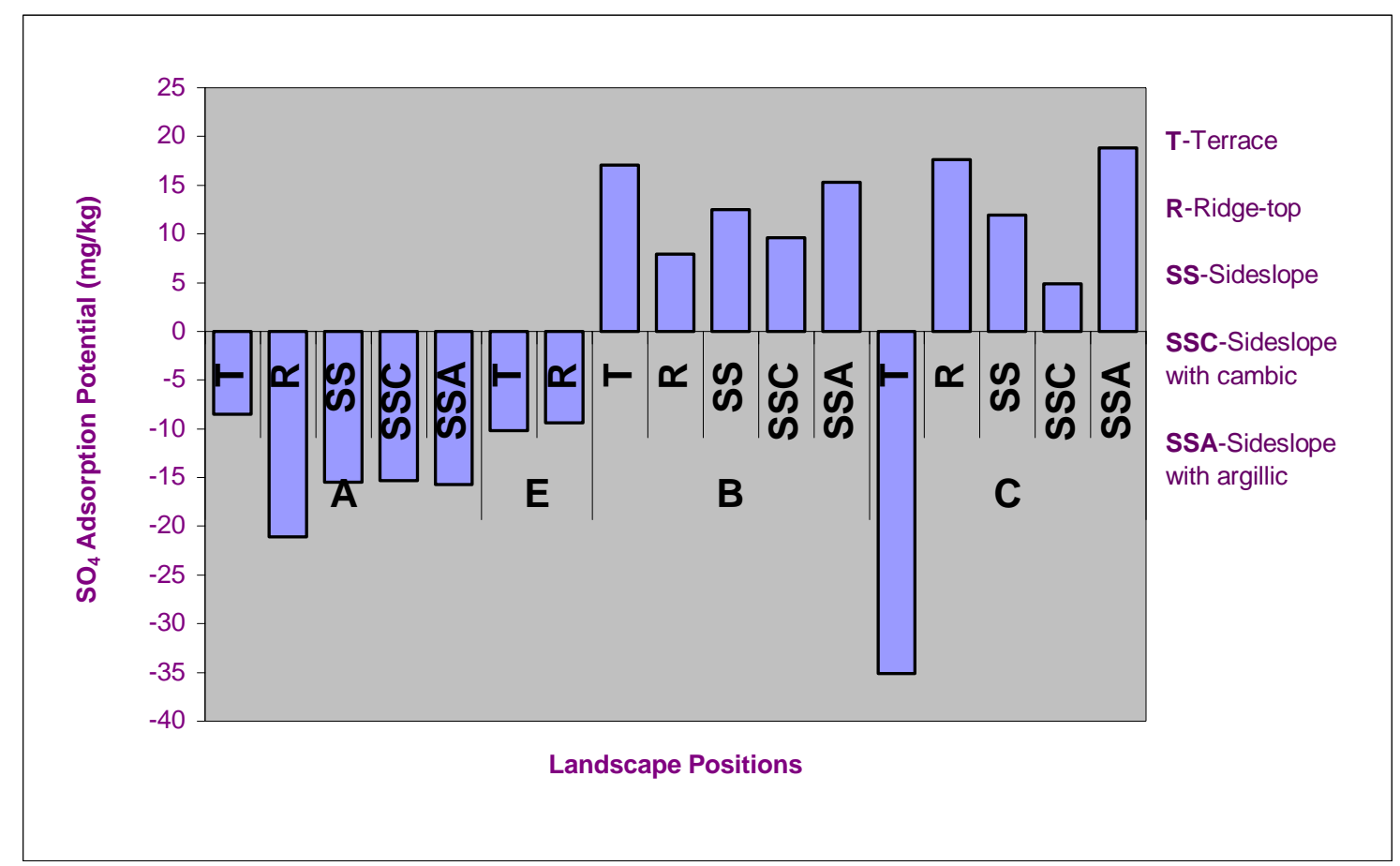

Figure 10. Index of sulfate adsorption potential for soil horizons in the Otter Creek Wilderness (neg. values=sulfate release; pos. values=soil capable of accepting sulfate).

As noted in Figure 10, C horizons in terrace soils appear to be heavily saturated with sulfate, however, this was not representative of the general trend of terrace $\mathrm{C}$ horizons. Site $\mathrm{T} 1 \mathrm{had}$ three $\mathrm{Cg}$ horizons that were out of character for $\mathrm{T}$ soils. In addition to the sulfate adsorption potential for these horizons being extremely negative, these layers also had very high extractable sulfate (Fig. 11) as well as a major increase in electrical conductivity (EC) (appendix A) when compared to the horizons above them. All other data for these horizons were congruent with the typical trends throughout the pedon and with other terrace soils. It was hypothesized that this could be an old surface horizon that has been buried and was portraying characteristics more representative of $\mathrm{A}$ horizons. This was unlikely though because the values reported for sulfate and EC were much higher in these $\mathrm{Cg}$ horizons than any data for A horizons in this or any pedon. 
Another possibility for the elevated values could be due to a bog that was adjacent to this site. These were Cg horizons, which indicated that they were inundated for part of the year, perhaps with water from the bog running through it. The wetland environment is generally high in sulfur (and sulfate), with the potential to create pyritic salts, increasing ionic strength or EC (Stephens, 2002). Without having data from this bordering bog, it was difficult to say whether or not this was the influence that caused such elevated values in these $\mathrm{Cg}$ horizons. If we eliminated the outlier values and average the $\mathrm{C}$ horizons of the other T soils, the sulfate adsorption potential would be $17.7 \mathrm{mg} / \mathrm{kg}$ which was more representative of $\mathrm{C}$ horizons and indicates that these horizons were still capable of receiving and retaining sulfate.

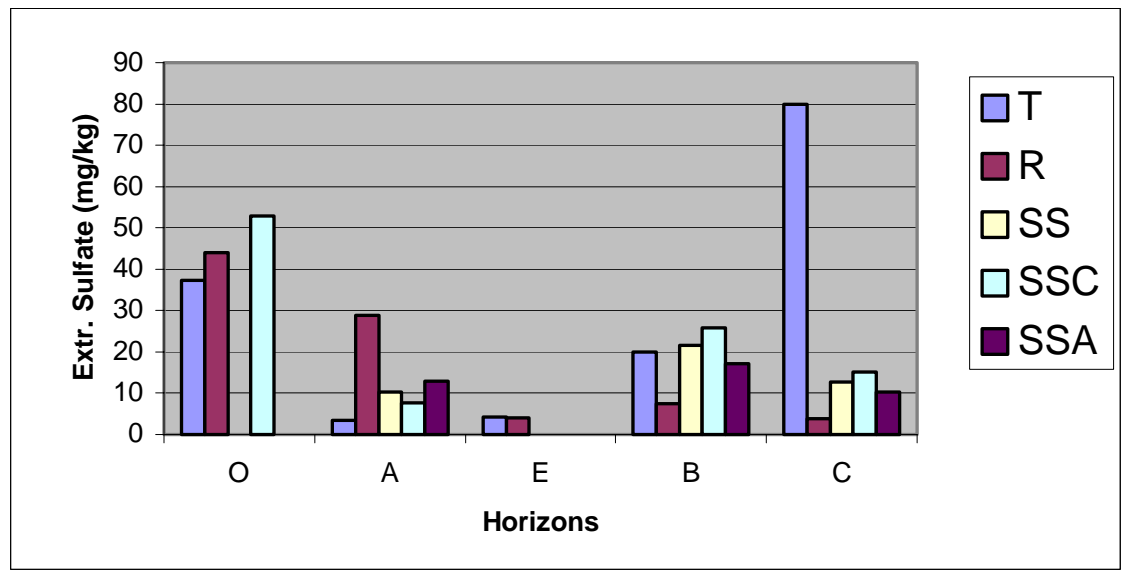

Figure 11. Extractable sulfate of soil horizons for various landscape positions in Otter Creek Wilderness

When we looked at the soils as a whole, R, SSC and SSA soils were capable of buffering this anion, with SSA soils having the greatest sulfate adsorption potential (Fig. 12). This could be due to the SSA soils having low organic carbon values in the B and C horizons, therefore there was less masking of the adsorption sites. Although, the SSA 
soils had the most potential for adsorbing sulfate, there were no significant differences for sulfate adsorption within horizons or within whole pedons among landscape positions.

Again, the $\mathrm{T}$ soils reflected that they were beyond the maximum sulfate retention load, however, these values were skewed due to the three $\mathrm{Cg}$ horizons that were mentioned earlier. If these outlying values were omitted, terrace soils also had the capacity to retain sulfate. Like the SSA soils, T soils were also low in organic carbon in the $\mathrm{B}$ and $\mathrm{C}$ horizons.

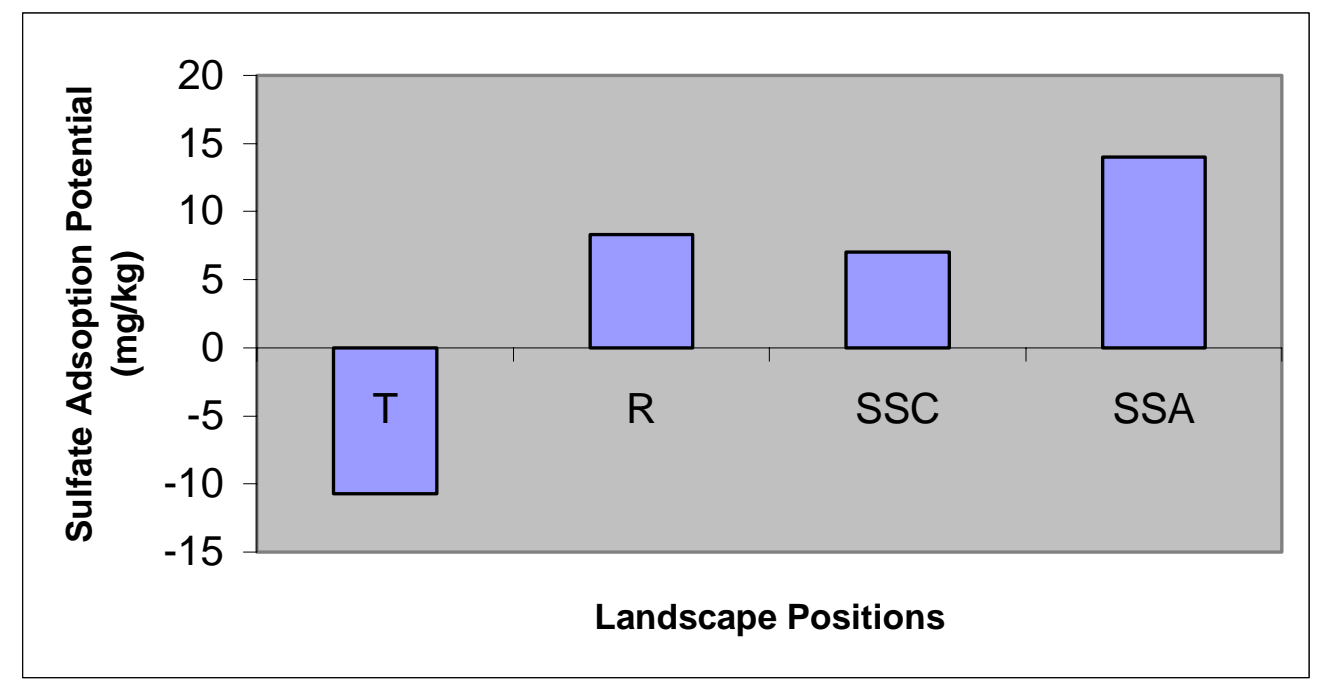

Figure 12. Sulfate adsorption potential of soils on various landscape positions in the Otter Creek Wilderness.

\section{BIOMASS ACCUMULATION}

When biomass data were calculated and analyzed, it was found that the data for the SSA sites were two to six times higher than data for any other site in this study. It was also found that these values were greater than any other site in West Virginia where 
the NRCS had collected biomass data (Personal communication, Stephen Carpenter, State Soil Scientist, Morgantown, WV). Because of the highly elevated values at the SSA sites, Mr. Eric Wharton, Research Forester with the USFS and lead author of the publication (Wharton and Griffith, 1998) reporting the allometric equations used in this current study, was contacted. Wharton indicated that the regression equations used to estimate biomass were not applicable to very large trees, especially trees with $\mathrm{DBH}$ as great as 37 inches, which was the largest tree found in this study. Therefore, biomass data for the SSA sites were not reported in this thesis. This information does indicate, however, that these sites are producing the largest trees in the study (and also the most trees) and are therefore the most productive.

Average total vegetative biomass for the T, R, and SSC sites ranged from 241 to $261 \mathrm{Mg} \mathrm{ha}^{-1}$ (Table 10). Jenkins (2000) found similar results in the same region with biomass ranging from 159 to $297 \mathrm{Mg} \mathrm{ha}^{-1}$. Biomass data for each individual tree species at each site and biomass data for each vegetative category are located in Appendix D.

Table 10. Biomass density of trees in Otter Creek with respect to landscape position

\begin{tabular}{|c|c|c|c|c|c|c|c|}
\hline & $\begin{array}{c}\text { Living } \\
(\mathrm{dbh}>5 ")\end{array}$ & $\begin{array}{c}\text { Dead } \\
(\mathrm{dbh}>5 ")\end{array}$ & $1-5 " d b h$ & $.1-1 " \mathrm{dbh}$ & Seedlings & Shrubs & Total \\
\hline Terrace & 212 & $<1$ & 27 & $<1$ & $<1$ & 16 & $255 a^{1}$ \\
\hline Ridgetop & 214 & 4 & 18 & $<1$ & $<1$ & 5 & $241 \mathrm{a}$ \\
\hline $\mathrm{SSC}^{2}$ & 225 & 8 & 26 & 2 & $<1$ & $<1$ & $261 \mathrm{a}$ \\
\hline
\end{tabular}

${ }^{\mathrm{T}}$ Values followed by the same letter are not significantly different $(\mathrm{p}<0.05)$.

${ }^{2} \mathrm{SSC}=$ Sideslope soils with cambic horizons. 
Rate of biomass accumulation followed the dame trends as the total biomass accumulation. Averages for pedons on the T, R, and SSC landscape positions ranged from 2.64 to $2.98 \mathrm{Mg} \mathrm{ha}^{-1} \mathrm{yr}^{-1}$ (Table 11).

Table 11. Average stand age and biomass accumulation of soils in the Otter Creek Wilderness across various landscape positions.

\begin{tabular}{lccc}
\hline Landscape & $\begin{array}{c}\text { Average } \\
\text { stand age }\end{array}$ & $\begin{array}{c}\text { Total biomass } \\
\text { accumulation }\end{array}$ & $\begin{array}{c}\text { Rate of biomass } \\
\text { accumulation }\end{array}$ \\
\hline Terrace & 81 & $\mathrm{Mg} \mathrm{ha}^{-1}$ & $\mathrm{Mg} \mathrm{ha}^{-1} \mathrm{yr}^{-1}$ \\
Ridgetop & 88 & $255 \mathrm{a}^{1}$ & $2.95 \mathrm{a}$ \\
SSC $^{2}$ & 87 & $241 \mathrm{a}$ & $2.64 \mathrm{a}$ \\
\hline
\end{tabular}

${ }^{1}$ Values followed by the same letter are not significantly different $(\mathrm{p}<0.05)$.

${ }^{2} \mathrm{SSC}=$ Sideslope soils with cambic horizons.

\section{SUMMARY AND CONCLUSIONS}

\section{General Observations}

Soils of Otter Creek Wilderness occurred on mostly acidic sandstone parent material, except for SSA soils which were forming in the Mauch Chunk geology. Sideslope soils were well drained and occurred on very steep slopes, while ridgetop and terrace soils were mostly somewhat poorly drained and poorly drained and occurred on nearly level to gently sloping landscapes. The vegetation of Otter Creek was mostly hardwood, deciduous species, with coniferous species mainly occurring on terrace soils and some on ridgetops.

Sideslope soils with argillic horizons were the healthiest soils in this study. They had the highest $\mathrm{pH}$ values of all the soils and the highest percent base saturation and 
exchangeable $\mathrm{Ca}$ concentrations. It was found that these soils were at a low risk for acid toxicity and had the highest molar $\mathrm{Ca}$ :Al ratio. In addition, the SSA soils were still capable of adsorbing sulfate. Also, SSA soils had the most diverse vegetation.

Terrace soils and SSC soils demonstrated the most adverse conditions, with ridgetop soils generally having moderate conditions. Sideslope cambic and T soils were the most acidic, and had the lowest percent base saturation and exchangeable $\mathrm{Ca}$ concentrations. Furthermore, they had the highest extractable Al values and the lowest molar Ca:Al ratio. Terrace and $\mathrm{R}$ soils were at the highest risk for acid toxicity to fine roots and symbiotic fungi in the humus layer, while SSC soils were at a moderate risk. Terrace soils were sulfate saturated and were no longer accepting this anion.

\section{Practical Applications}

The soils of Otter Creek were highly acidic and had low nutrient status, except for the SSA soils because of their development on the nutrient rich, nutrient retainable Mauch Chunk geology. Many factors can affect the productivity of forests, however, for the Appalachian hardwood forests, the greatest threats to sustainable forestry are nutrient imbalances and acidity (Adams et al., 2000). Although, most forest soils have low pH values and thrive at these levels, soils in Otter Creek were extremely acid which has led to base cation release and decreased nutrient uptake by plants, as well as, introducing high levels of $\mathrm{Al}$ which can be toxic to plants. Some studies show that liming can amend some of these nutrient problems, however, the results are mixed. For instance, liming sugar maple stands in Pennsylvania restored more vigorous growth and canopy health (Long et al., 1997). Vance (1996) stated that long-term productivity of forests could be 
enhanced by using wood-fired boiler ashes as a replacement for agricultural lime. On the other hand, liming can also induce nitrate leaching (Johnson et al., 1995) in addition to the desorption of sulfate from soil binding sites (Prenzel and Meiwes, 1994). Since most of these soils were already sulfate saturated, reducing the soils' ability to retain the anion through liming might not be the best management solution.

Low nutrient status was another problem plaguing the Otter Creek soils. Adding fertilizer, nutrient rich organic matter, or other amendments to increase base cations are some options for increasing fertility at these sites. However, there are mixed reports about whether or not adding nutrient amendments to large-scale forests is practical. Grigal (2000) stated that except in areas where liming has been used to alleviate nutrient imbalances due to extreme acidity, base cations are not routinely added to managed forests. This is due to the self-sufficiency of forests resulting from gradual shifts in nutrient pools as stands mature, which results in greater accumulation of nutrients in living biomass and detrital materials, the return of nutrients from the plant to the mineral soil, and the declining dependence of trees on the mineral soil to meet annual requirements in favor of internal retranslocation and nutrient release through decomposition of the forest floor (Grigal 2000). Spratt (1998) agreed, noting that litter input was the key to maintaining long-term surface soil nutrients. Interestingly, after applying organic matter amendments to his soils, Spratt found that the additions resulted in a loss of $\mathrm{K}$, but a greater retention of $\mathrm{Mg}$. Fertilizing with $\mathrm{K}$ has improved foliar nutrient status and growth rates in declining maples and additions of $\mathrm{Ca}$ and $\mathrm{Mg}$ led to improved tree vigor in some stands (McLaughlin and Percy, 1999). Additions of Ca have also increased foliar growth and $\mathrm{Ca}$ concentration of red spruce, but additions of $\mathrm{Ca}$ 
associated with liming also have caused negative responses, usually attributed to altered soil chemistry due to change in $\mathrm{pH}$ (Grigal, 2000). However, as suggested by Grigal (2000), manipulations of $\mathrm{Ca}$ can be problematic because alterations of $\mathrm{Ca}$ in the soil affect the Ca-Al-pH interactions and markedly change the soil chemical status.

Obviously, there is much to research with respect to adding amendments to forested sites, and this discussion did not include economics and feasibility issues. If liming and fertilization are to be considered, they should be established specifically on a site-to-site basis because of inherent differences among soils and sites. With regards to Otter Creek, this area is a designated wilderness area and management is probably not an option. However, these data do have value for other non-wilderness sites, as well as, providing background data to the USFS for monitoring health of the forest in the wilderness. 


\section{REFERENCES}

Adams, M.B., J.A. Burger, A.B. Jenkins, and L. Zelazny. 2000. Impact of harvesting and atomospheric pollution on nutrient depletion of eastern US hardwood forests. For. Eco. and Mgmnt. 138: 301-319.

Anonymous. 2001. Great Outdoors Recreation Pages: Otter Creek Wilderness Area. http://www.gorp.com/gorp/resource/US_Wilderness_Area/WV_otter.HTM.

Arbestain, M.C., M.E. Bareal, and F. Macias. 1999. Parent material influence on sulfate sorption in forest soils from northwestern spain. Soil Sci. Soc. Am. J. 63:19061914.

Berg, B. 2000. Litter decomposition and organic matter turnover in northern forest soils. For. Eco. and Mgmnt. 133:13-22.

Brady, N.C. and R.R. Weil. 1999. The Nature of Soils. Twelfth ed. Prentice-Hall, Upper Saddle River, NJ.

Brown, S.L., P. Schroeder, and J.S. Kern. 1999. Spatial distribution of biomass in forests of the eastern USA. For. Eco. and Mgmnt. 123:81-90.

Buol, S.W., F.D. Hole, R.J. McCracken, and R.J. Southard. 1997. Soil Genesis and Classification, $4^{\text {th }}$ edition. Iowa State University Press. Ames, Iowa.

Carter, B.J. and E. J. Ciolkosz. 1980. Soil temperature regimes of the central Appalachians. Soil Sci. Soc. Am. J. 44:1052-1058.

Ciolkosz, E.J., W.J. Waltman, and N.C. Thurman. 1992. Fragipans in Pennsylvania soils. Agronomy Series No. 119. Pennsylvania State University. University Park, PA 16802.

Cronan, C.S. and D.F. Grigal. 1995. Use of calcium/aluminum ratios as indicators of stress in forest ecosystems. J. Environ. Qual. 24: 209-226.

Egan, L. 1998. Determination of sulfate by flow injection alanysis. Zellweger Analytics INC. QuickChem method 12-116-10-1-D.

Evangelou, V.P. 1998. Environmental Soil and Water Chemistry: Principles and Applications. John Wiley and Sons. Ames, Iowa.

Federer, C.A., J.W. Hornbeck, L.M. Tritton, C.W. Martin, R.S. Pierce, and C.T. Smith. 1989. Long-term depletion of calcium and other nutrients in eastern US forests. Environ. Manage. 13:593-601. 
Feldman, S.B., L.W. Zelazny, and J.C. Baker. 1991. High-elevation forest soils of the southern Appalachians. II. Geomorphology, pedogenesis, and clay mineralogy. Soil Sci. Soc. Am. J. 55:1782-1791.

Frank, P.S., Jr., R.R. Hicks, Jr., and E.J. Harner, Jr. 1984. Biomass predicted by soil-site factors: a case study in north central West Virginia. Can. J. For. Res. 14:137-140.

Fuller, R.D., M.B. David, and C.T. Driscoll. 1985. Sulfate adsorption relationships in forested spodosols of the northeastern USA. Soil Sci. Soc. Am. J. 49: 1034-1040.

Garten, Jr.,C.T. 2000. Nitrogen saturation and soil N availability in a high-elevation spruce and fir forest. Water, Air, and Soil Pol. 120:295-313.

Grigal, D.F. 2000. Effects of extensive forest management on soil productivity. For. Eco. and Mgmnt. 138:167-185.

Grigal, D.F. and L.F. Ohmann. 1992. Carbon storage in upland forests of the lake states. Soil Sci. Soc. Am. J. 56:935-943.

Grossman, R.B. and T.G. Reinsch. 2002. The Solid Phase. In J.H. Dane and G.C. Topp (ed.) Methods of Soil Analysis. Part 4. Physical Methods. SSSA book series, no. 5. 677 S. Segoe Rd, Madison, WI 53711, USA.

Halvin, J.L., J.D. Beaton, S.L. Tisdale, and W.L. Nealson. 1999. Soil Fertility and Fertilizers: An Introduction to Nutrient Management, $6^{\text {th }}$ Ed. Prentice Hall, Upper Saddle River, NJ.

Harrison, R.B., D.W. Johnson, and D.E. Todd. 1989. Sulfate adsorption and desorption reversibility in a variety of forest soils. J. Environ. Qual. 18:419-426.

Hicks, R.R.Jr. and P.S. Frank, Jr. 1984. Relationship of aspect to soil nutrients, species importance and biomass in a forested watershed in West Virginia. For. Eco.and Mgmnt. 8:281-291.

Huntington, T.G., R.P. Hooper, C.E. Johnson, B.T. Aulenback, R. Cappellato, and A.E. Blum. 2000. Calcium depletion in a southeastern United States forest ecosystem. Soil Sci. Soc. Am. J. 64:1845-1858.

Indorante, S.J., L.R. Follmer, R.D. Hammer, and P.G. Koenig. 1990. Particle-size analysis by a modified pipette procedure. Soil Sci. Soc. Am. J. 54:560-563.

Jenkins, A. 2001. Organic Carbon and Fertility of Forest Soils on the Allegheny Plateau of West Virginia. M.S. thesis, WVU, Morgantown. http://etd.wvu.edu//ETDS/E2486/Jenkins_A_B_thesis.pdf 
Johnson, D.W. and D.E. Todd. 1998. Harvesting effects on long-term changes in nutrient pools of mixed oak forests. Soil Sci. Soc. Am. J. 62:1725-1735.

Johnson, D.W., W.T. Swank, and J.M. Vose. 1995. Effects of liming on soils and streamwaters in a deciduous forest: comparison of field results and simulations. J. Environ. Qual. 24:1105-1117.

Johnson, D.W., R.B. Susfalk, P.F. Brewer, and W.T. Swank. 1999. Simulated effects of reduced sulfur, nitrogen and base cation deposition on soils and solutions in southern Appalachian forests. J. Environ. Qual. 28:1336-1346.

Khanna, P.K., J. Prenzel, K.J. Meiwes, B. Ulrich, and E. Matzner. 1987. Dynamics of sulfate retention by acid forest soils in an acidic deposition environment. Soil Sci. Soc. Am. J. 51:446-452.

Knoepp, J.D. and W.T. Swank. 1994. Long-term soil chemistry changes in aggrading forest ecosystems. Soil Sci. Soc. Am. J. 58:325-331.

Lee, F.Y., T.L. Yuan, and V.W. Carlisle. 1988. Nature of cementing materials in ortstein horizons of selected Florida spodosols: II. Soil properties and chemical form(s) of aluminum. Soil Sci. Soc. Am. J. 52:1796-1801.

Long, R.P., S.B. Horsley, and P.R. Lilja. 1997. Impact of forest liming on growth and crown vigor of sugar maple and associated hardwoods. Can. J. For. Res. 27:15601573.

Losche, C.K. and W. W. Beverage. 1967. Soil Survey of Tucker County and part of Northern Randolph County, West Virginia. USDA Soil Conservation Service and Forest Service, in cooperation with the West Virginia Agricultural Experiment Station. U.S. Gov. Printing Office. Washington, D.C.

Lyon, J. and W.E. Sharpe. 1999. An assessment of the Ca:Al ratios of selected Pennsylvania forest soils. Water, Air, and Soil Pol. 109:53-65.

MacDonald, N.W. and J.B. Hart, Jr.1990.Relating sulfate adsorption to soil properties in Michigan forest soils. Soil Sci. Soc. Am. J. 54:238-245.

Marshall, T.J., J.W. Holmes, and C.W. Rose. 1996. Soil physics, $3^{\text {rd }}$ edition. Cambridge University Press. New York, New York.

McColl, J.G. and N. Gressel. 1995. Forest soil organic matter: characterization and modern methods of analysis. p.13-32. In W.W. McFee and J.M. Kelly (ed.) Carbon Forms and Functions in Forest Soils. SSSA, Madison, WI. 
McLaughlin, S. and K. Percy. 1999. Forest health in North America: Some perspectives on actual and potential roles of climate and air pollution. Water, Air, and Soil Pol. 116:151-197.

McNabb, D.H., A.D. Startsev, and H. Nguyen. 2001. Soil wetness and traffic level effects on bulk density and air-filled porosity of compacted boreal forest soils. Soil Sci. Soc. Am. J. 65:1238-1247.

Meiwes, K.J., P.K. Khanna, and B. Ulrich. 1986. Parameters for describing soil acidification and their relevance to the stability of forest ecosystems. For. Eco. Mgmnt. 15:161-179.

Mitchell, M.J., M.B. David, and R.B. Harrison. 1992. Sulphur Dynamics in Forest Ecosystems. John Wiley and Sons. New York, New York.

Mount, H.R. and R.F. Paetzold. 2002. The temperature regime for selected soils in the United States. United States Department of Agriculture, Natural Resources Conservation Service, National Soil Survey Center, Lincoln, Nebraska. Soil Survey Investigation Report No. 48.

Prescott, C.E., D.G. Maynard, and R. Laiho. 2000. Humus in northern forests: friend or foe?. For. Eco. and Mgmnt. 133:23-36.

Prenzel, J. and K-J. Meiwes. 1994. Sulfate sorption under acid deposition: Modeling field data from forest liming. J. Environ. Qual. 23:1212-1217.

Rennenberg, H. and A. Gressler. 1999. Consequences of N deposition to forest ecosystems-Recent results and future research needs. Water, Air, and Soil Pollution. 116:47-64.

Richter, D.D., D. Markewitz, C.G. Wells, H.L. Allen, J.K. Dunscombe, K. Harrison, P.R. Heine, A. Stuanes, B. Urrego, and G. Bonani. 1995. Carbon cycling in a loblolly pine forest: Implications for the missing carbon sink and for the concept of soil. SSSA, Madison, WI.

Schoenholtz, S.H., H. Van Miegroet, and J.A. Burger. 2000. A review of chemical and physical properties as indicators of forest soil quality: challenges and oppurtunities. For. Eco. and Mgmnt. 138: 335-356.

Schwertmann, U. 1988. Some properties of soils and synthetic iron oxides. D. Reidel Pub. Co., Boston MA.

Shaffer, P.W. and D.L. Stevens, Jr. 1991. Evaluation of procedures for aggregating nonlinear sulfate adsorption isotherm data. Soil Sci. Soc. Am. J. 55:684-692. 
Soil Survey Division Staff. 1993. Soil Survey Manual. USDA Handbook. No. 18. U.S. Gov. Printing Office, Washington, D.C.

Soil Survey Staff. 1996. Soil Survey Laboratory Methods Manual. Soil Survey Investigations Report No. 42. Version 3.0 National Soil Survey Center, Lincoln NE.

Soil Survey Staff. 1998. Keys to Soil Taxonomy. $8^{\text {th }}$ Edition. USDA-NRCS. Washington, D.C.

Soil Survey Staff. 1999. Soil Taxonomy. Agriculture Handbook No. 436. USDA-NRCS. U.S. Gov. Printing Office. Washington, D.C.

Spratt, Jr., H.G. 1998. Organic sulfur and the retention of nutrient cations in forest surface soils. Water, Air, and Soil Pol. 105:305-317.

Ste-Marie, C. and D. Pare. 1999. Soil, pH and N availability effects on net nitrification in the forest floors of a range of boreal forest stands. Soil Bio. and Biochem. 31: 1579-1589.

Stephens, K. 2002. Characterization of wetland soils in the Beaver Creek watershed. M.S. thesis, WVU, Morgantown. http://etd.wvu.edu//ETDS/E2864/Stephens_Kyle_thesis.pdf

Trettin, C.C., D.W. Johnson, and D.E. Todd, Jr. 1999. Forest nutrient and carbon pools at Walker Branch watershed: Changes during a 21-year period. Soil Sci. Soc. Am. J. 63:1436-1448.

Van Cleve, K. and R.F. Powers. 1995. Soil Carbon, Soil Formation, and Ecosystem Development. SSSA, Madison, WI.

Vance, E.D.1996. land application of wood-fired and combination boiler ashes: an overview. J. Environ. Qual. 25:937-944.

Vitousek, P.M., T. Fahey, D.W. Johnson, and M.J. Swift. 1988. Element interactions in forest ecosystems: succession, allometry, and input-output budgets. Biogeochemistry. 5:7-34.

Wharton, E.H. and D.M. Griffith. 1998. Estimating total forest biomass in Maine, 1995. US Forest Service Res. Bull. NE-142. Northeastern Res. Sta., Rednor, PA.

Wiant, H.V., Jr., F. Castaneda, C.E. Sheetz, A.C. Colaninno, and J.C. DeMoss. 1979. Equations for prediction weights of some Appalachian hardwoods. p. 21-26. WV Forestry Notes 7. 
Young, H.E., J.H. Ribe, and K. Wainwright. 1980. Weight tables for tree and shrub species in Maine. Misc. Rep. 230. University of Maine, Life Sci. Agr. Exp. Sta., Orono, ME. 


\section{APPENDIX A}

\section{PROFILE DESCRIPTIONS}

(Note: All horizon designations are shown how they appeared on the field description sheet). 


\section{Site: T1}

\section{Pedon: 99-83002}

Location: Randolph County, West Virginia, Otter Creek above limer.

Classification: Loamy-skeletal, mixed, active, mesic Typic Endoaquults

Vegetation: Spruce, Hemlock

Slope: $2.5 \%$

Parent Material: Alluvium, Colluvium

Physiography: Coalluvial terrace, dissected by histic, drains into adjacent bog.

Drainage class: Somewhat poorly drained

Elevation: $982 \mathrm{~m}$

Latitude: N $38^{\circ} 56^{\prime} 44.5^{\prime \prime}$

Longitude: W $79^{\circ} 39^{\prime}$ 55.1"

Described and sampled by Tony Jenkins, August 5, 1999 and August 24, 1999, respectfully.

Oi1,2 - 0 to $3 \mathrm{~cm} ; 15$ percent rock fragments; many very fine to coarse roots; extremely acid.

$\mathbf{O e}-3$ to $7 \mathrm{~cm}$; 15 percent rock fragments; many very fine to coarse roots; ultra acid; clear wavy boundary.

Oa -7 to $15 \mathrm{~cm}$; black (7.5YR 2.5/1) mucky loam; weak fine granular structure; very friable; 25 percent rock fragments; few fine to medium roots; ultra acid; abrupt wavy boundary.

E - 15 to $25 \mathrm{~cm}$; grayish brown (10YR 5/2) loam; weak medium subangular blocky structure; friable; 25 percent rock fragments; few fine medium roots; extremely acid; clear wavy boundary.

EBg -25 to $34 \mathrm{~cm} ; 70 \%$ light brownish gray (10YR 6/2), 15\% yellowish brown (10YR 5/8), and $15 \%$ very dark grayish brown (10YR 3/2) and (10YR 2/1) loam/sandy loam; weak medium and coarse subangular blocky structure; friable; 30 percent rock fragments; few fine to medium roots; extremely acid; gradual wavy boundary.

Bg1 - 34 to $51 \mathrm{~cm}$; 60\% light brownish gray (10YR 6/2) and 40\% yellowish brown (10YR 5/6-8) clay loam; weak coarse prismatic to weak medium subangular blocky structure; friable; 30 percent rock fragments; few fine and medium roots; extremely acid; gradual wavy boundary.

Bg2 - 51 to $69 \mathrm{~cm}$; 60\% light brownish gray (10YR 6/2) and 40\% strong brown (7.5YR 5/6-8) clay loam; weak coarse prismatic to weak medium subangular blocky structure; friable; 50 percent rock fragments; few fine roots; extremely acid; clear wavy boundary.

BC -69 to $85 \mathrm{~cm} ; 80 \%$ strong brown (7.5YR 5/6-8), 10\% light brownish gray (10YR 6/2), and $10 \%$ pale brown (10YR 6/3) sandy clay loam; weak medium subangular blocky structure; friable; 50 percent rock fragments; very strongly acid; clear wavy boundary.

Cg1 - 85 to $110 \mathrm{~cm} ; 90 \%$ (2.5Y 4/1) and 10\% brown (7.5YR 4/4) sandy clay/sandy clay loam; massive; friable; 30 percent rock fragments; extremely acid; clear wavy boundary.

Cg2 - 110 to $121 \mathrm{~cm}$; olive gray (5Y 4/2) sandy clay loam; massive friable; 30 percent rock fragments; extremely acid.

Note: This profile description appears how it was described in the field. However, after laboratory analyses, it was determined that both Bg horizons were actually Btg's. Also, this pedon was only described to $\mathrm{Cg} 2$, but a $\mathrm{Cg} 3$ horizon was sampled and laboratory data is present in Appendices B and C. 


\section{Site: T2}

\section{Pedon: 99-93006}

Location: Randolph County, West Virginia, coalluvial terrace on Yellow Creek, near headwaters. About 150m west of McGowan Mountain Trail, 130m west of Yellow Creek.

Classification: Loamy-skeletal, mixed, active, mesic, Typic Endoaquults

Vegetation: Red spruce, hemlock, yellow birch, red maple, heavy rhododendron understory.

Slope: 5\%

Parent Material: colluvium/alluvium from sandstone/shale

Physiography: coalluviual terrace/bench

Drainage class: Somewhat poorly drained

Elevation: $1030 \mathrm{~m}$

Latitude: N $38^{\circ} 58^{\prime} 26^{\prime \prime}$

Longitude: W $79^{\circ} 41^{\prime} 06.7^{\prime \prime}$

Described and sampled by Tony Jenkins, August 4, 1999 and October 13, 1999, respectfully.

Oi1 - 0 to $2 \mathrm{~cm}$; extremely acid.

Oe -2 to $6 \mathrm{~cm}$; ultra acid.

Oa- 6 to $12 \mathrm{~cm}$; black (n 2/0); mucky sandy loam; 80 percent rock fragments; ultra acid.

E/A - 12 to $17 \mathrm{~cm}$; black (7.5YR 2/1) and light brownish gray (10YR 6/2) gravelly, very fine sandy loam; 55 percent rock fragments; extremely acid.

E - 30 to $41 \mathrm{~cm}$; grayish brown and light brownish gray (10YR 5-6/2) gravelly, very fine sandy loam; few fine (5YR 5/6) concentrations; 55 percent rock fragments; extremely acid.

Bw -41 to $61 \mathrm{~cm}$; yellowish brown (10YR 5/6) gravelly, very fine sandy clay loam; many coarse light brownish gray (10YR 6/2) depletions and many coarse (10YR 6/2) depletions; 55 percent rock fragments; extremely acid.

BCg -61 to $79 \mathrm{~cm}$; grayish brown and light brownish gray (10YR 5-6/2) gravelly, very fine sandy clay loam; many coarse yellowish brown (10YR 5/6) concentrations; 50 percent rock fragments; very strongly acid.

C - 79 to $99 \mathrm{~cm}$; weak red (2.5YR 5/3) gravelly, very fine sandy loam; common medium yellowish brown (10YR 5/8) and strong brown (7.5YR 5/8) concentrations; 55 percent rock fragments; very strongly acid.

Cg-101 to 150+ cm; grayish brown (10YR 5/2) gravelly, very fine sandy clay loam; common medium yellowish brown (10YR5/8) and strong brown (7.5YR 5/8) concentrations; 50 percent rock fragments; very strongly acid.

Note: This profile description appears how it was described in the field. However, after laboratory analyses, it was determined that the Bw horizon was actually a Bt. Also, this pedon was described and sampled without the inclusion of a layer between 17 and $30 \mathrm{~cm}$ and a layer between 99 and $100 \mathrm{~cm}$. 


\section{Site: T3}

\section{Pedon: 00-83002}

Location: Randolph County, West Virginia, Along Otter Creek 1/2 mile below Limer

Classification: Fine, mixed, active, mesic Aquic Haplohumults

Vegetation: Yellow Birch, Red Maple, Hemlock, Very heavy Rhododendron

Slope: $4 \%$

Stoniness: BLDY overall

Parent Material: Sandstone (alluvial over alluvial or coalluvial)

Physiography: High floodplain/ low terrace

Drainage class: Moderately well drained

Elevation: $957 \mathrm{~m}$

Latitude: N $38^{\circ} 57^{\prime} 00.2^{\prime \prime}$

Longitude: W 79 40'04.7'

Additional Notes: Area of fine to fine silty mantle $(0-1 \mathrm{~m})$ thick over sandstone-

SIC layer. Pockets of thick Mn concentration in B horizons.

Described and sampled by Tony Jenkins, October 31, 2000.

Oi1 -2 to $0 \mathrm{~cm}$; extremely acid; abrupt wavy boundary.

Oi2 -0 to $3 \mathrm{~cm}$; extremely acid.

Oe -3 to $9 \mathrm{~cm}$; ultra acid; abrupt wavy boundary.

A - 9 to $18 \mathrm{~cm}$; black (7.5YR 2.5/1) silt loam; 20 percent dark grayish brown (10YR4/2);

moderate fine granular structure; very friable; $5 \%$ rock fragments; many very fine to coarse roots; extremely acid; clear wavy boundary.

B/A- 18 to $28 \mathrm{~cm} ; 70$ percent yellowish brown, dark grayish brown $(10$ YR 5/6, 4/2) silt loam; 30 percent black (10YR2/1); moderate fine to medium subangular blocky structure; friable; 5 percent rock fragments; many very fine to coarse roots; extremely acid; clear wavy boundary.

Bw1 - 28 to $51 \mathrm{~cm}$; yellowish brown (10YR 5/6) silt loam; weak medium subangular blocky structure; friable; 5 percent rock fragments; many very fine to coarse roots; extremely acid; clear wavy boundary.

Bw2 - 51 to $93 \mathrm{~cm}$; yellowish brown (10YR 5/6) silty clay loam; common medium light brownish gray (10YR 6/2) depletions and few fine strong brown (7.5YR 4/6) concentrations; weak medium subangular blocky structure; friable; 5 percent rock fragments; many fine to coarse roots; very strong acid; clear wavy boundary.

BC - 93 to $118 \mathrm{~cm}$; yellowish brown (10YR 5/6) silty clay loam; many medium light brownish gray (10YR 6/2) depletions and common fine strong brown (7.5YR 5/8) concentrations; weak medium subangular blocky structure; friable; 60 percent rock fragments; many fine to coarse roots; very strong acid; clear wavy boundary.

Cg- 118 to $170+\mathrm{cm}$; light brownish gray (2.5Y and 10YR 6/2) silty clay loam; common medium light brownish gray (10YR 6/2) depletions and common medium to coarse yellowish brown (10YR 5/8) concentrations; massive; friable; 70 percent rock fragments; many fine to medium roots; very strong acid.

Note: This profile description appears how it was described in the field. However, after laboratory analyses, it was determined that both Bw horizons were actually Bt's. 


\section{Site: R1}

\section{Pedon: 99-93002}

Location: Randolph County, West Virginia, head of Devil's Gulch, on dissected ridgetop position.

Classification: Fine-loamy, mixed, superactive, frigid Aeric Fragiaquepts

Vegetation: Red maple, beech, cherry, yellow birch, hayscented fern

Slope: $4 \%$

Parent Material: mud-flow, shale, colluvium

Physiography: broad ridgetop

Drainage class: Somewhat poorly drained (redox features say poorly, but not hydric site)

Elevation: $1090 \mathrm{~m}$

Latitude: N $38^{\circ} 59^{\prime} 00.3^{\prime \prime}$

Longitude: W $79^{\circ} 40^{\prime} 13.5^{\prime \prime}$

Described and sampled by Tony Jenkins, August 11, 1999 and August 25, 1999, respectfully.

Oi- 0 to $2 \mathrm{~cm}$; many very fine to coarse roots; extremely acid; abrupt wavy boundary.

Oa -2 to $3 \mathrm{~cm}$; very dark brown (10YR 2/2) mucky silt loam; weak fine and medium granular structure; very friable; 5 percent rock fragments; many very fine to coarse roots; extremely acid; clear wavy boundary.

A - 3 to $8 \mathrm{~cm}$; very dark brown (10YR 2/2) silt loam; weak medium granular structure; very friable; 5 percent rock fragments; common fine to coarse roots; ultra acid; clear wavy boundary.

B/E - 8 to $15 \mathrm{~cm} ; 50 \%$ yellowish brown (10YR 5/6), 30\% light yellowish brown (2.5Y 6/3) and $20 \%$ dark yellowish brown (10YR 4/4) silt loam; moderate medium and coarse subangular blocky structure; friable; 5 percent rock fragments; few fine roots; extremely acid; clear wavy boundary.

Bw - 15 to 46 cm; yellowish brown (10YR 5/8) clay loam; light yellowish brown (2.5Y 6/3) on ped faces; common coarse light brownish gray (10YR 6/2) depletions; weak coarse prismatic to moderate fine and medium subangular blocky structure; friable; common, fine manganese concentrations; 10 percent rock fragments; clear wavy boundary.

Bgx1 - 46 to $68 \mathrm{~cm}$; dark gray (n 4/0) clay loam; coarse prismatic structure; firm; 5 percent rock fragments; very strongly acid; clear wavy boundary.

Bgx2 - 68 to $125 \mathrm{~cm}$; dark gray (n 4/0) silt loam; coarse prismatic structure; firm; 5 percent rock fragments; very strongly acid; abrupt wavy boundary.

C -125 to $150+\mathrm{cm} ; 60 \%$ yellowish brown (10YR 5/8) and $40 \%$ olive brown (2.5Y 5/3) silt loam; common coarse gray (10YR 5/1) depletions; massive; friable; 10 percent rock fragments; very strongly acid. 


\section{Site: R2}

\section{Pedon: 00-83001}

Location: Randolph County, West Virginia-near the Stuart Gap side of Otter Creek entrance on road to Bear Haven.

Classification: Fine-loamy, mixed, semiactive, frigid Aquic Fragiudepts

Vegetation: Red maple, red spruce, cherry, beech, yellow birch

Slope: $3 \%$

Parent Material: Shale and sandstone, colluvium

Physiography: Ridgetop

Drainage class: Poorly drained

Elevation: $1160 \mathrm{~m}$

Latitude: N $38^{\circ} 56^{\prime} 37^{\prime \prime}$

Longitude: W $79^{\circ} 41^{\prime} 57.2^{\prime \prime}$

Described and sampled by Tony Jenkins, August 7, 2000.

Oi1 - 0 to $1 \mathrm{~cm}$; very strongly acid.

Oi2 - 1 to $3 \mathrm{~cm}$; extremely acid.

A - 3 to $10 \mathrm{~cm}$; very dark brown (10YR 2/2) silt loam; weak fine granular structure; friable; 10 percent rock fragments; many very fine to coarse roots; ultra acid; clear wavy boundary.

AB - 10 to $16 \mathrm{~cm}$; brown (10YR 4/3) silt loam; weak medium subangular blocky structure; friable; 10 percent rock fragments; many very fine to medium roots; ultra acid; clear wavy boundary.

Bw1 - 16 to $30 \mathrm{~cm}$; light yellowish brown (10YR 6/4) loam; 30 percent strong brown (7.5YR 5/6) and 10 percent brown (10YR 5/3) concentrations; 10 percent grayish brown (10YR 5/2) depletions; weak medium subangular blocky structure; friable; 10 percent rock fragments; common fine roots; extremely acid; clear wavy boundary.

Bw2 - 30 to $44 \mathrm{~cm}$; light yellowish brown (10YR 6/4) loam; 30 percent strong brown (7.5YR 5/6) concentrations and 20 percent grayish brown (10YR 5/2) depletions; weak medium subangular blocky structure; friable; 20 percent rock fragments; few fine to medium roots; extremely acid; clear wavy boundary.

Bw3 - 44 to $70 \mathrm{~cm}$; light yellowish brown (10YR 6/4) clay loam; 50 percent strong brown (7.5YR 5/6) and 10 percent dark yellowish brown (10YR 3/4) concentrations; 20 percent gray (10YR 5/1) depletions; weak medium and coarse subangular blocky structure; friable; 15 percent rock fragments; few fine and medium roots; very strongly acid; gradual wavy boundary.

Bx - 70 to $110 \mathrm{~cm}$; yellowish brown (10YR 5/4) clay loam; 20 percent strong brown (7.5YR 5/6) concentrations and 20 percent gray (10YR 5/1) depletions; weak coarse prismatic structure; firm; 15 percent rock fragments; very strongly acid; clear wavy boundary.

C - 110 to 150+ cm; brown (10YR 4/3) loam; 5 percent gray (10YR 5/1) depletions; massive; 40 percent rock fragments; very strongly acid. 


\section{Site: R3}

\section{Pedon: 00-93001}

Location: Tucker County, West Virginia

Classification: Loamy-skeletal, mixed, active, frigid Aquic Fragiudults

Vegetation: Hemlock, yellow birch, cherry, red maple, red spruce, rhododendron

Slope: $1 \%$

Parent Material: Sandstone and shale, colluvium, frost-wedge heave from periglacial

activity

Physiography: Broad ridgetop

Drainage class: Somewhat poorly drained

Elevation: $1120 \mathrm{~m}$

Latitude: N $39^{\circ} 00^{\prime}$ 52"

Longitude: W $79^{\circ} 40^{\prime} 04^{\prime \prime}$

Additional Notes: Boulder size flags of sandstone and shale at $70^{\circ}$ upward west from greater them 60" up to 3'. Pedon contains pockets of Bh material. Few clay films at bottom of Bw.

Described and sampled by Tony Jenkins, August 8, 2000.

Oi1 - 0 to $1 \mathrm{~cm}$; 90 percent rock fragments; extremely acid.

Oi2 -1 to $4 \mathrm{~cm}$; 90 percent rock fragments; extremely acid.

Oe -4 to $7 \mathrm{~cm}$; reddish brown (5YR 3/3); 90 percent rock fragments; extremely acid.

Oa1 - 7 to $29 \mathrm{~cm}$; black (N 2/0); very friable; 90 percent rock fragments; many very fine to very coarse roots; ultra acid; clear wavy boundary.

Oa2 - 29 to $42 \mathrm{~cm}$; black (10YR 2/1); weak fine granular structure; very friable; 90 percent rock fragments; many very fine to very coarse roots; abrupt wavy boundary.

$\mathbf{E}-42$ to $55 \mathrm{~cm}$; gray (10YR 6/1) and light brownish gray (10YR 6/2) sandy loam; gray (7.5YR

6/1) depletions; weak medium subangular blocky structure; firm; 50 percent rock fragments; few fine to coarse roots; extremely acid; abrupt wavy boundary.

Bw - 55 to $75 \mathrm{~cm}$; yellowish brown (10YR 5/6) loam; gray (10YR 6/1) depletions and brownish yellow (10YR 6/8) concentrations; weak medium subangular blocky structure; friable; 35 percent rock fragments; few medium roots; extremely acid; clear wavy boundary.

Bx - 75 to $120 \mathrm{~cm}$; dark yellowish brown (10YR 4/4) loam; gray (10YR 6/1) prism coatings; weak coarse prismatic to weak medium subangular blocky structure; firm; 60 percent rock fragments; extremely acid; clear wavy boundary.

Cg - 120 to $150+\mathrm{cm}$; dark grayish brown (10YR 4/2) and gray (10YR 5/1) silty clay loam/ clay loam; yellowish brown (10YR 5/6) concentrations; massive; firm; 90 percent rock fragments; extremely acid.

Note: This profile description appears how it was described in the field. However, after laboratory analyses, it was determined that the $\mathrm{Bw}$ and $\mathrm{Bx}$ horizons were actually a Bt and a Btx, respectively. 


\section{Site: R4}

\section{Pedon: 00-93003}

Location: Randolph County, West Virginia

Classification: Loamy-skeletal, mixed, superactive, frigid Aeric Fragiaquepts

Vegetation: Hemlock, red spruce, yellow birch

Slope: $4 \%$

Parent Material: Sandstone and shale, colluvium

Physiography: Broad ridgetop

Drainage class: Poorly drained

Elevation: $1120 \mathrm{~m}$

Latitude: N $38^{\circ} 59^{\prime} 10.8^{\prime \prime}$

Longitude: W $79^{\circ} 36^{\prime} 47.9^{\prime \prime}$

Described and sampled by Tony Jenkins, August 10, 2000.

Oi1 - 1 to $0 \mathrm{~cm}$; many very fine to coarse roots; extremely acid; abrupt wavy boundary.

$\mathbf{O i 2}-0$ to $2 \mathrm{~cm}$; 50 percent roots; many very fine to coarse roots; extremely acid; clear wavy boundary.

Oe -2 to $4 \mathrm{~cm}$; 50 percent roots; many very fine to coarse roots; clear wavy boundary.

$\mathbf{O a} / \mathbf{A}$ - 4 to $12 \mathrm{~cm}$; black (7.5YR 2.5/1); weak fine granular structure; 50 percent roots; many very fine to coarse roots; extremely acid; abrupt wavy boundary.

Eg - 12 to 20 cm; brown-pinkish gray (7.5YR 5-6/2) sandy loam; common fine and medium brownish yellow and yellowish brown (10YR5/6 and 6/6) and common fine pale brown (10YR 6/3) concentrations; weak medium to coarse subangular blocky structure; firm; 40 percent rock fragments; few fine to medium roots; extremely acid; abrupt wavy boundary.

$\mathbf{B h} / \mathbf{B w}-20$ to $30 \mathrm{~cm}$; 70 percent dark reddish brown (5YR 3/2) loam; 30 percent yellowish brown (10YR5/6) concentrations; moderate fine to medium subangular blocky structure; friable; 30 percent rock fragments; few fine to medium roots; extremely acid; abrupt broken boundary.

Bw -30 to $44 \mathrm{~cm}$; yellowish brown (10YR 5/6) sandy clay loam; common fine yellowish red (5YR 5/6), strong brown (7.5YR5/6) concentrations and (2.5Y 6/2) depletions; weak medium subangular blocky structure; friable; 20 percent rock fragments; many very fine to coarse roots; extremely acid; clear wavy boundary.

Bx - 44 to $75 \mathrm{~cm}$; yellowish brown (10YR 5/6) sandy loam; common medium and coarse weak red (2.5YR 6/2) depletions; weak coarse prismatic structure; very firm; 20 percent rock fragments; extremely acid; clear wavy boundary.

BCg -75 to $100 \mathrm{~cm}$; gray (2.5Y 6/1) sandy clay loam; common fine and medium yellowish brown (10YR 5/6) concentrations; weak very coarse prismatic structure; firm; 25 percent rock fragments; very strong acid; gradual wavy boundary.

Cg - 100 to 150+ cm; gray (2.5Y 5/1) silty clay loam; common fine yellowish brown (10YR 5/6) concentrations and reddish gray $(2.5 \mathrm{Y} 7 / 1)$ depletions; massive; firm; 50 percent rock fragments; very strong acid. 


\section{Site: SSC1}

\section{Pedon: 99-83001}

Location: Randolph County, West Virginia

Classification: Loamy-skeletal, mixed, superactive, mesic Typic Fragiudepts

Vegetation: Red maple, yellow birch, frasier magnolia, under story beech, spruce

Slope: $45 \%$

Parent Material: Pottsville colluvium

Physiography: Backslope

Drainage class: Well drained

Aspect: SW

Elevation: $1010 \mathrm{~m}$

Latitude: N $38^{\circ} 56^{\prime} 49.5^{\prime \prime}$

Longitude: W $79^{\circ} 39^{\prime} 50.1^{\prime \prime}$

Additional Notes: This pedon included a nearly folistic, fragmental area of thickened A A/E. it had some spodic character underlying.

Right (other) side of pedon description: A $-70 \%$ rocks, to $76 \mathrm{~cm}, \mathbf{B s}--76-89 \mathrm{~cm}, 7.5 \mathrm{YR}$ $4 / 6$, then into $\mathrm{Bw}$, other horizons same as below.

Very poor vegetation, but not unusual for the $\mathrm{S}$ facing slopes of this area.

Described and sampled by Tony Jenkins, August 3, 1999 and August 24, 1999, respectfully.

Oi1 -0 to $3 \mathrm{~cm}$; extremely acid.

Oi2 -3 to $6 \mathrm{~cm}$; 30 percent rock fragments; common fine and very fine roots; extremely acid;

clear wavy boundary.

Oe -6 to $8 \mathrm{~cm}$; 30 percent rock fragments; many very fine to coarse roots; ultra acid; clear wavy boundary.

$\mathbf{O a} / \mathbf{A}-8$ to $15 \mathrm{~cm}$; black (7.5YR2.5/1); weak medium granular structure; very friable; 45 percent rock fragments; many very fine to coarse roots; ultra acid; clear irregular boundary.

A/E - 15 to $30 \mathrm{~cm}$; very dark grayish brown, pale brown, and dark yellowish brown (10YR 3/2, $6 / 3,4 / 6)$ loam; weak fine and medium subangular blocky structure; friable; 50 percent rock fragments; many very fine to coarse roots; ultra acid; clear broken boundary.

BE - 30 to $58 \mathrm{~cm}$; yellowish brown and pale brown (10YR 5/4 and 6/3) silt loam; weak fine and medium subangular blocky structure; friable; 50 percent rock fragments; common very fine to coarse roots; extremely acid; clear broken boundary.

Bw - 58 to $89 \mathrm{~cm}$; yellowish brown (10YR 5/6) silt loam; weak medium subangular blocky structure; friable; 40 percent rock fragments; few very fine to coarse roots; extremely acid; clear wavy boundary.

Bx -89 to $125 \mathrm{~cm}$; yellowish brown (10YR 5/4) loam; weak medium subangular blocky structure; very firm; 50 percent rock fragments; very strongly acid; clear wavy boundary.

$\mathbf{C x}-125$ to $170+\mathrm{cm}$; yellowish brown (10YR 5/4) sandy loam; massive; firm; 65 percent rock fragments; very strongly acid 


\section{Site: SSC2}

\section{Pedon: 99-93005}

Location: Tucker County, West Virginia, about 250m north of Otter creek, about 300m west of Coal Run.

Classification: Loamy-skeletal, mixed, superactive, mesic, Humic Dystrudepts Vegetation: Poplar, red oak, beech, sugar maple, basswood

Slope: $68 \%$

Parent Material: Mauch Chunk colluvium

Physiography: mid-backslope

Drainage class: Well drained

Aspect: $62^{\circ} \mathrm{NE}$

Elevation: $670 \mathrm{~m}$

Latitude: N $39^{\circ} 02^{\prime}$ 22.7'"

Longitude: W $79^{\circ} 37^{\prime} 26.2^{\prime \prime}$

Described and sampled by Tony Jenkins, August 19, 1999 and October 5, 1999, respectfully.

Oi1 - 0 to $2.5 \mathrm{~cm}$; strongly acid.

Oi2 - abrupt wavy boundary.

A- 2.5 to $9 \mathrm{~cm}$; dark reddish brown (5YR 3/3) silt loam; weak fine granular structure; very friable; 15 percent rock fragments; many very fine to coarse roots; extremely acid; clear wavy boundary.

BA -9 to $30 \mathrm{~cm}$; dusky red (2.5YR 3/3) silt loam; weak fine and medium subangular blocky structure; friable; 15 percent rock fragments; many very fine to coarse roots; extremely acid; clear wavy boundary.

Bt1 - 30 to $41 \mathrm{~cm}$; dusky red (2.5YR 3/4) silt loam; weak fine and medium subangular blocky structure; friable; 20 percent rock fragments; few fine, thin, discontinuous clay films; many very fine to coarse roots; extremely acid; gradual wavy boundary.

Bt2 - 41 to $61 \mathrm{~cm}$; dusky red (2.5YR 3/4) silt loam; weak medium subangular blocky structure; friable; 35 percent rock fragments; few fine, thin, discontinuous clay films; common fine and medium roots; extremely acid; clear wavy boundary.

BC -61 to $79 \mathrm{~cm}$; dusky red (2.5YR 3/4) silt loam; weak fine and medium subangular blocky structure; friable; 50 percent rock fragments; common fine and medium roots; extremely acid; gradual wavy boundary.

C - 79 to $99 \mathrm{~cm}$; dusky red (2.5YR 3/4) silt loam; massive; friable; 80 percent rock fragments; few fine roots; extremely acid; abrupt wavy boundary.

Note: This profile description appears how it was described in the field. However, after laboratory analyses, it was determined that the Bt horizons did not have enough of a clay increase to warrant an argillic horizon and therefore were classified as Bw1 and Bw2. 


\section{Site: SSC3}

\section{Pedon: 00-93002}

Location: Randolph County, West Virginia

Classification: Loamy-skeletal, mixed, superactive, mesic Typic Dystrudepts

Vegetation: Red Maple, Cherry, Cucumber Maple, Mountain Magnolia

Slope: $38 \%$

Parent Material: Sandstone, colluvium

Physiography: Steep side slope

Drainage class: Well drained

Aspect: NE

Elevation: $939 \mathrm{~m}$

Latitude: N $38^{\circ} 58^{\prime} 13.3^{\prime \prime}$

Longitude: W $79^{\circ} 37^{\prime} 59.3$ '

Described and sampled by Tony Jenkins and Jason Teets, August 9, 2000.

Oi1 -2 to $0 \mathrm{~cm}$; very strongly acid.

Oi2 -0 to $2 \mathrm{~cm}$; very strongly acid.

Oe -2 to $6 \mathrm{~cm}$; extremely acid.

Oa/A - 6 to $11 \mathrm{~cm}$; black (10YR 2/1) silt loam; 50 percent rock fragments; many very fine to coarse roots; ultra acid; clear wavy boundary.

AB - 11 to $19 \mathrm{~cm}$; dark yellowish brown (10YR 3/4) silt loam/loam; few fine light olive brown (2.5Y 5/3) and strong brown (7.5YR 5/6) concentrations; weak medium to fine subangular blocky structure; very friable; 40 percent rock fragments; many very fine to coarse roots; ultra acid; clear wavy boundary.

Bw1 - 19 to $35 \mathrm{~cm}$; dark yellowish brown (10YR 4/6) silt loam; weak medium to fine subangular blocky structure; friable; 40 percent rock fragments; many very fine to coarse roots; extremely acid; clear wavy boundary.

Bw2 - 35 to $65 \mathrm{~cm}$; yellowish brown (10YR 5/6) silt loam; weak medium to fine subangular blocky structure; friable; 40 percent rock fragments; common very fine to coarse roots; extremely acid; gradual wavy boundary.

Bw3 - 65 to $85 \mathrm{~cm}$; light olive brown (2.5Y 5/6) silt loam; weak medium to fine subangular blocky structure; friable; 40 percent rock fragments; few very fine to medium roots; extremely acid; gradual wavy boundary.

BC -85 to $113 \mathrm{~cm}$; light olive brown (2.5Y 5/6) loam; weak medium to fine subangular blocky structure; friable; 60 percent rock fragments; few fine to medium roots; very strongly acid; clear wavy boundary.

C1 - 113 to $138 \mathrm{~cm} ; 60$ percent light olive brown (2.5Y 5/6) and 40 percent light olive brown (2.5Y 5/4) loam; few fine light yellowish brown (2.5Y 6/3) and strong brown (7.5YR 5/6) concentrations; massive; firm; 80 percent rock fragments; very strongly acid; clear wavy boundary.

C2 -138 to $160 \mathrm{~cm} ; 50$ percent light olive brown (2.5Y 5/4) and 50 percent olive brown $(2.5 \mathrm{Y}$ 4/3) loam; massive; very firm; 85 percent rock fragments; extremely acid. 


\section{Site: SSA1}

\section{Pedon: 99-93001}

Location: Tucker County, West Virginia, about 0.7 miles out Turkey Run Trail from Fernow entrance (near Big Springs Gap).

Classification: Fine-loamy, mixed, active, mesic Ultic Hapludalfs

Vegetation: Poplar, red oak, sugar maple, basswood, beech, ramps

Slope: $50 \%$

Parent Material: Mauch Chunk colluvium

Physiography: Upper backslope

Drainage class: Well

Aspect: E

Elevation: $847 \mathrm{~m}$

Latitude: N $39^{\circ} 02^{\prime} 16.0^{\prime \prime}$

Longitude: $\mathrm{W} 79^{\circ} 39^{\prime} 31.6^{\prime \prime}$

Described and sampled by Tony Jenkins, August 10, 1999 and August 23, 1999, respectfully.

Oi- 0 to $2.5 \mathrm{~cm}$; abrupt wavy boundary; slightly acid.

A1 - 2.5 to $7 \mathrm{~cm}$; dark brown (7.5YR 3/2) silt loam; moderate fine and medium granular structure; very friable; 20 percent rock fragments; many very fine to coarse roots; extremely acid; clear wavy boundary.

A2 - 7 to $13 \mathrm{~cm}$; dark brown (10YR 3/3) silt loam; moderate medium granular structure; very friable; 25 percent rock fragments; many very fine to coarse roots; clear wavy boundary.

BA - 13 to $19 \mathrm{~cm}$; reddish brown (5YR 4/3) silt loam; weak fine and medium subangular blocky structure; friable; 20 percent rock fragments; common fine to coarse roots; extremely acid; clear wavy boundary.

Bt1 - 19 to $53 \mathrm{~cm}$; reddish brown (5YR 4/4) silty clay loam; weak medium subangular blocky structure; friable; 20 percent rock fragments; few, thin, discontinuous, patchy clay films; common fine to coarse roots; very strongly acid; clear wavy boundary.

Bt2 - 53 to $75 \mathrm{~cm}$; reddish brown (5YR 4/4) clay loam; weak medium subangular blocky structure; firm; 20 percent rock fragments; few, thin, discontinuous, patchy clay films; few fine roots; very strongly acid; gradual wavy boundary.

Bt3 - 75 to $113 \mathrm{~cm}$; reddish brown (5YR 4/4) clay loam; weak medium subangular blocky structure; firm; 35 percent rock fragments; few, thin, discontinuous, patchy clay films; few fine roots; very strongly acid; gradual wavy boundary.

BC - 113 to $137 \mathrm{~cm}$; reddish brown (5YR 4/4) loam; weak medium subangular blocky structure; firm; 40 percent rock fragments; few fine roots; very strongly acid; gradual wavy boundary.

C -137 to 160+ cm; reddish brown (5YR 4/4) loam; massive; firm; 55 percent rock fragments; very strongly acid. 


\section{Site: SSA2}

\section{Pedon: 99-93003}

Location: Tucker County, West Virginia.

Classification: Fine-silty, mixed, superactive, mesic Typic Hapludults

Vegetation: Poplar, red oak, locust, beech, sugar maple, red maple

Slope: $44 \%$

Parent Material: Mauch Chunk colluvium

Physiography: lower backslope/ steep footslope

Drainage class: Well drained

Aspect: $210^{\circ} \mathrm{SW}$

Elevation: $650 \mathrm{~m}$

Latitude: N $39^{\circ} 02^{\prime} 38.2^{\prime \prime}$

Longitude: W $79^{\circ} 37^{\prime} 30.3^{\prime \prime}$

Described and sampled by Tony Jenkins, August 12, 1999 and August 26, 1999, respectfully.

Oi1 - 0 to $1 \mathrm{~cm}$; moderately acid.

Oi2 - 1 to $3 \mathrm{~cm}$; moderately acid; abrupt wavy boundary.

A - 3 to $14 \mathrm{~cm}$; dark brown (7.5YR 3/2) silt loam; moderate very fine and fine granular structure; very friable; 30 percent rock fragments; common very fine to medium roots; extremely acid; clear wavy boundary.

BA- 14 to $34 \mathrm{~cm}$; brown (7.5YR 4/4) silt loam; weak medium subangular blocky structure; very friable; 20 percent rock fragments; many very fine to coarse roots; extremely acid; clear wavy boundary.

Bt1 - 34 to $60 \mathrm{~cm}$; reddish brown (5YR 4/4) silty clay loam; weak medium subangular blocky structure; friable; 25 percent rock fragments; few, thin, discontinuous, patchy clay films; common very fine to medium roots; extremely acid; gradual wavy boundary.

Bt2 - 60 to $107 \mathrm{~cm}$; reddish brown (5YR 4/4) silt loam; weak medium subangular blocky structure; friable; 30 percent rock fragments; few, thin, discontinuous, patchy clay films; few very fine to medium roots; very strongly acid; gradual wavy boundary.

BC - 107 to $138 \mathrm{~cm}$; dusky red (2.5YR 3/4) silt loam; weak medium subangular blocky structure; firm; 40 percent rock fragments; few very fine to medium roots; very strongly acid; gradual wavy boundary.

C - 138 to $152 \mathrm{~cm}$; dusky red (2.5YR 3/4) silt loam; massive; firm; 40 percent rock fragments; few very fine to medium roots; very strongly acid. 


\section{Site: SSA3}

\section{Pedon: 99-93004}

Location: Tucker County, West Virginia.

Classification: Fine-silty, mixed, active, mesic Typic Hapludults

Vegetation: Red oak, locust, beech, red maple

Slope: $59 \%$

Parent Material: Mauch Chunk colluvium

Physiography: Midslope shoulder/ backslope

Drainage class: Well drained

Aspect: N

Elevation: $662 \mathrm{~m}$

Latitude: $39^{\circ} 2{ }^{\prime} 42.55^{\prime \prime} \mathrm{N}$

Longitude: $79^{\circ} 37^{\prime} 31.75^{\prime \prime} \mathrm{W}$

Additional Notes: I received organic horizons for this pedon but none were described.

Described and sampled by Tony Jenkins, August 19, 1999 and August 16, 1999, respectfully.

A1 - 0 to $2 \mathrm{~cm}$; black (7.5YR 2.5/1) silt loam; weak fine and medium granular structure; very friable; 15 percent rock fragments; many very fine to coarse roots; extremely acid; clear wavy boundary.

A2- 2 to $7 \mathrm{~cm}$; dark brown (7.5YR 3/2) silt loam; weak medium and coarse granular structure; very friable; 15 percent rock fragments; many very fine to coarse roots; clear wavy boundary.

AB - 7 to $12 \mathrm{~cm}$; dark brown (7.5YR 3/4) silt loam; weak fine subangular blocky structure; very friable; 20 percent rock fragments; many very fine to coarse roots; extremely acid; clear wavy boundary.

BA - 12 to $29 \mathrm{~cm}$; brown (5YR 4/3) silt loam; moderate fine subangular blocky structure; friable; 20 percent rock fragments; many very fine to coarse roots; extremely acid; clear wavy boundary.

Bt -29 to $65 \mathrm{~cm}$; brown (5YR 4/4) silt loam; weak fine and medium subangular blocky structure; friable; 30 percent rock fragments; few patchy, thin, discontinuous clay films; common very fine to medium roots; extremely acid; gradual wavy boundary.

BC -65 to $86 \mathrm{~cm}$; brown (5YR 4/4) silt loam; weak fine and medium subangular blocky structure; friable; 40 percent rock fragments; common very fine to medium roots; extremely acid; clear wavy boundary.

C - 86 to $101 \mathrm{~cm}$; brown (5YR 4/4) silt loam; massive; friable; 60 percent rock fragments; few fine roots; very strongly acid; abrupt wavy boundary. 


\section{APPENDIX B}

\section{SOIL PHYSICAL DATA FOR EACH PEDON}

(Note: All horizon designations are shown how they appeared on the field description sheet). 


\section{Table 12. T1 Physical Data}

\begin{tabular}{ccccc} 
Horizon & Depth & $\begin{array}{c}\text { Rock } \\
\text { Fragments } \\
(\% \text { by wt) }\end{array}$ & $\begin{array}{c}\text { Bulk Density } \\
(\text { frame }) \\
\left(\mathrm{Mg} \mathrm{m}^{-3}\right)\end{array}$ & $\begin{array}{c}\text { Bulk Density } \\
(\text { clod }) \\
\left(\mathrm{Mg} \mathrm{m}^{-3}\right)\end{array}$ \\
\hline Oi1 \& Oi2 & $0-3$ & 0.00 & 0.07 & $\mathrm{~N} / \mathrm{A}$ \\
Oe & $3-7$ & 0.00 & 0.16 & $\mathrm{~N} / \mathrm{A}$ \\
Oa & $7-15$ & 1.24 & 0.22 & $\mathrm{~N} / \mathrm{A}$ \\
E & $15-25$ & 0.18 & $\mathrm{~N} / \mathrm{A}$ & 1.6 \\
EB g & $25-34$ & 1.60 & $\mathrm{~N} / \mathrm{A}$ & 1.6 \\
Bg1 & $34-51$ & 10.12 & $\mathrm{~N} / \mathrm{A}$ & 1.7 \\
Bg2 & $51-69$ & 12.86 & $\mathrm{~N} / \mathrm{A}$ & 1.7 \\
BC & $69-85$ & 9.34 & $\mathrm{~N} / \mathrm{A}$ & 1.7 \\
Cg1 & $85-110$ & 21.11 & $\mathrm{~N} / \mathrm{A}$ & 1.9 \\
Cg2 & $110-121$ & 23.64 & $\mathrm{~N} / \mathrm{A}$ & 1.9 \\
Cg3 & $121-160+$ & 24.80 & $\mathrm{~N} / \mathrm{A}$ & 2.0
\end{tabular}

\begin{tabular}{|c|c|c|c|c|c|c|}
\hline Horizon & $\begin{array}{l}\text { Depth } \\
(\mathrm{cm})\end{array}$ & v. coarse & coarse & $\begin{array}{l}\text { Sand } \\
\text { medium }\end{array}$ & Fine & v. fine \\
\hline Oi1 \& Oi2 & $0-3$ & $\mathrm{~N} / \mathrm{A}$ & $\mathrm{N} / \mathrm{A}$ & $\mathrm{N} / \mathrm{A}$ & $\mathrm{N} / \mathrm{A}$ & $\mathrm{N} / \mathrm{A}$ \\
\hline $\mathrm{Oe}$ & $3-7$ & $\mathrm{~N} / \mathrm{A}$ & $\mathrm{N} / \mathrm{A}$ & $\mathrm{N} / \mathrm{A}$ & $\mathrm{N} / \mathrm{A}$ & $\mathrm{N} / \mathrm{A}$ \\
\hline $\mathrm{Oa}$ & $7-15$ & $\mathrm{~N} / \mathrm{A}$ & $\mathrm{N} / \mathrm{A}$ & $\mathrm{N} / \mathrm{A}$ & $\mathrm{N} / \mathrm{A}$ & $\mathrm{N} / \mathrm{A}$ \\
\hline$E$ & $15-25$ & 0.4 & 2.0 & 13.7 & 19.4 & 8.7 \\
\hline EB g & $25-34$ & 0.7 & 3.6 & 18.4 & 22.9 & 7.1 \\
\hline $\mathrm{Bg} 1$ & $34-51$ & 1.6 & 4.2 & 14.6 & 18.4 & 6.1 \\
\hline $\mathrm{Bg} 2$ & $51-69$ & 3.5 & 7.7 & 21.1 & 18.4 & 4.6 \\
\hline $\mathrm{BC}$ & $69-85$ & 1.1 & 3.0 & 18.3 & 27.6 & 6.3 \\
\hline $\mathrm{Cg} 1$ & $85-110$ & 4.1 & 12.4 & 18.2 & 22.2 & 9.1 \\
\hline $\mathrm{Cg} 2$ & $110-121$ & 5.6 & 12.6 & 17.2 & 21.4 & 9.1 \\
\hline $\mathrm{Cg} 3$ & $121-160+$ & 5.6 & 13.6 & 18.8 & 20.6 & 8.2 \\
\hline Horizon & $\begin{array}{l}\text { Depth } \\
(\mathrm{cm})\end{array}$ & Sand & $\begin{array}{c}\text { Silt } \\
---(\%)--\end{array}$ & Clay & FT & LT \\
\hline Oi1 \& Oi2 & $0-3$ & $\mathrm{~N} / \mathrm{A}$ & $\mathrm{N} / \mathrm{A}$ & $\mathrm{N} / \mathrm{A}$ & $\mathrm{N} / \mathrm{A}$ & $\mathrm{N} / \mathrm{A}$ \\
\hline $\mathrm{Oe}$ & $3-7$ & $\mathrm{~N} / \mathrm{A}$ & $\mathrm{N} / \mathrm{A}$ & $\mathrm{N} / \mathrm{A}$ & $\mathrm{N} / \mathrm{A}$ & $\mathrm{N} / \mathrm{A}$ \\
\hline $\mathrm{Oa}$ & $7-15$ & $\mathrm{~N} / \mathrm{A}$ & $\mathrm{N} / \mathrm{A}$ & $\mathrm{N} / \mathrm{A}$ & $\mathrm{N} / \mathrm{A}$ & $\mathrm{N} / \mathrm{A}$ \\
\hline$E$ & $15-25$ & 44.2 & 41.3 & 14.5 & L & $\mathrm{L}$ \\
\hline EB g & $25-34$ & 52.7 & 35.3 & 12.0 & L & $\mathrm{SL} / \mathrm{L}$ \\
\hline $\mathrm{Bg} 1$ & $34-51$ & 44.6 & 35.5 & 19.9 & $\mathrm{CL}$ & $\mathrm{L}$ \\
\hline $\mathrm{Bg} 2$ & $51-69$ & 55.3 & 20.6 & 24.1 & $\mathrm{CL}$ & SCL \\
\hline $\mathrm{BC}$ & $69-85$ & 56.0 & 24.2 & 19.8 & SCL & SL/SCL \\
\hline $\mathrm{Cg} 1$ & $85-110$ & 59.4 & 32.0 & 8.6 & SCL & SL \\
\hline $\mathrm{Cg} 2$ & $110-121$ & 59.1 & 33.2 & 7.6 & SCL & SL \\
\hline $\mathrm{Cg} 3$ & $121-160+$ & 61.1 & 32.0 & 6.9 & $\mathrm{~N} / \mathrm{A}$ & SL \\
\hline
\end{tabular}




\section{Table 13. T2 Physical Data}

\begin{tabular}{ccccc} 
Horizon & Depth & $\begin{array}{c}\text { Rock } \\
\text { Fragments } \\
(\% \text { by wt. })\end{array}$ & $\begin{array}{c}\text { *Bulk Density } \\
\text { (frame) } \\
\left(\mathrm{Mg} \mathrm{m}^{-3}\right)\end{array}$ & $\begin{array}{c}{ }^{*} \text { Bulk Density } \\
(\mathrm{clod}) \\
\left(\mathrm{Mg} \mathrm{m}^{-3}\right)\end{array}$ \\
\hline Oi & $0-2$ & 2.25 & 0.09 & $\mathrm{~N} / \mathrm{A}$ \\
$\mathrm{Oe}$ & $2-6$ & 2.67 & $\mathrm{~N} / \mathrm{A}$ & $\mathrm{N} / \mathrm{A}$ \\
$\mathrm{Oa}$ & $6-12$ & 3.85 & 0.09 & $\mathrm{~N} / \mathrm{A}$ \\
$\mathrm{EA}$ & $12-17$ & 50.21 & $\mathrm{~N} / \mathrm{A}$ & 1.8 \\
$\mathrm{E}$ & $30-41$ & 36.99 & $\mathrm{~N} / \mathrm{A}$ & 1.9 \\
$\mathrm{Bw}$ & $41-61$ & 26.02 & $\mathrm{~N} / \mathrm{A}$ & 1.8 \\
$\mathrm{BCg}$ & $61-79$ & 36.80 & $\mathrm{~N} / \mathrm{A}$ & 2.0 \\
$\mathrm{C}$ & $79-99$ & 26.75 & $\mathrm{~N} / \mathrm{A}$ & 1.6 \\
$\mathrm{Cg}$ & $101-150+$ & 28.81 & $\mathrm{~N} / \mathrm{A}$ & 1.8
\end{tabular}

*both bulk density procedures represent the $<2 \mathrm{~mm}$ fine earth fraction

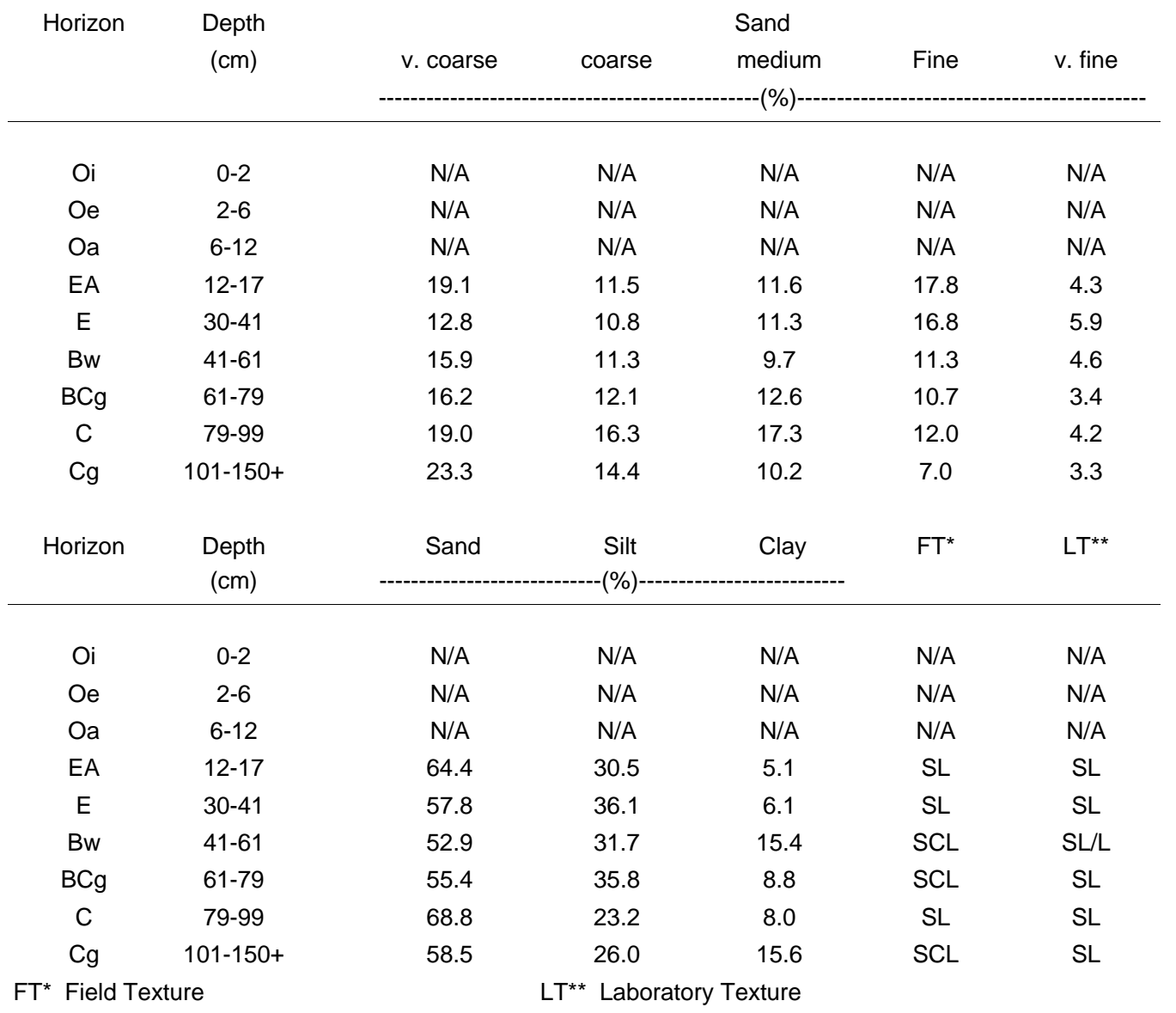




\section{Table 14. T3 Physical Data}

\begin{tabular}{ccccc} 
Horizon & Depth & $\begin{array}{c}\text { Rock } \\
\text { Fragments } \\
(\% \text { by wt. })\end{array}$ & $\begin{array}{c}\text { *Bulk Density } \\
\text { (frame) } \\
\left(\mathrm{Mg} \mathrm{m}^{-3}\right)\end{array}$ & $\begin{array}{c}{ }^{*} \text { Bulk Density } \\
(\mathrm{clod}) \\
\left(\mathrm{Mg} \mathrm{m}^{-3}\right)\end{array}$ \\
\hline Oi1 & $2-0$ & 0.00 & $\mathrm{~N} / \mathrm{A}$ & $\mathrm{N} / \mathrm{A}$ \\
Oi2 & $0-3$ & 0.00 & $\mathrm{~N} / \mathrm{A}$ & $\mathrm{N} / \mathrm{A}$ \\
Oe & $3-9$ & 0.00 & $\mathrm{~N} / \mathrm{A}$ & $\mathrm{N} / \mathrm{A}$ \\
A & $9-18$ & 0.00 & $\mathrm{~N} / \mathrm{A}$ & $\mathrm{N} / \mathrm{A}$ \\
B/A & $18-28$ & 0.00 & $\mathrm{~N} / \mathrm{A}$ & $\mathrm{N} / \mathrm{A}$ \\
Bw1 & $28-51$ & 0.00 & $\mathrm{~N} / \mathrm{A}$ & 1.0 \\
Bw2 & $51-93$ & 0.00 & $\mathrm{~N} / \mathrm{A}$ & 1.3 \\
BC & $93-118$ & 0.04 & $\mathrm{~N} / \mathrm{A}$ & 1.3 \\
Cg & $118-170+$ & 0.06 & $\mathrm{~N} / \mathrm{A}$ & 1.5
\end{tabular}

*both bulk density procedures represent the $<2 \mathrm{~mm}$ fine earth fraction

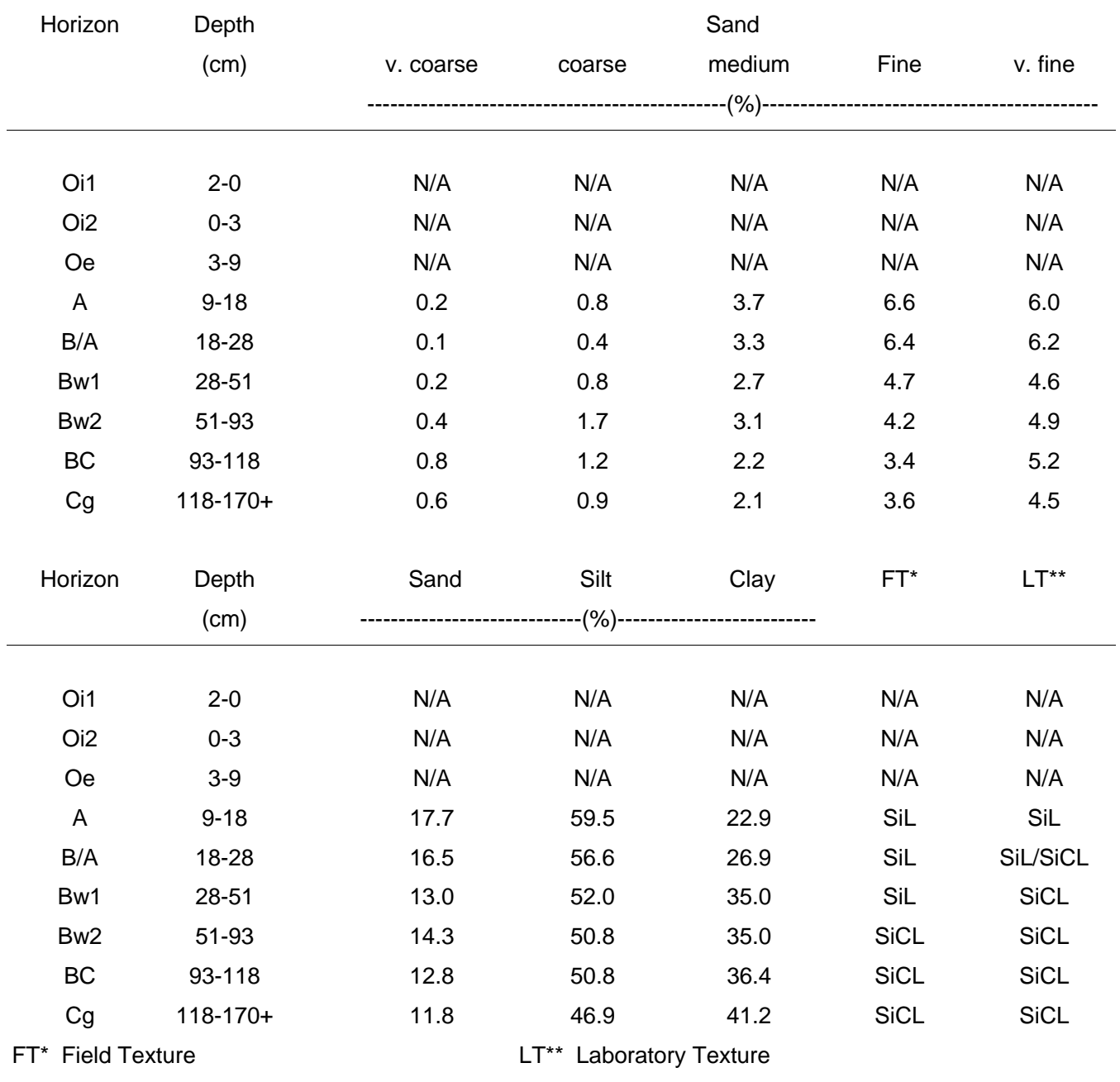




\section{Table 15. R1 Physical Data}

\begin{tabular}{ccccc} 
Horizon & Depth & $\begin{array}{c}\text { Rock } \\
\text { Fragments } \\
(\% \text { by wt. })\end{array}$ & $\begin{array}{c}\text { *Bulk Density } \\
(\text { frame }) \\
\left(\mathrm{Mg} \mathrm{m}^{-3}\right)\end{array}$ & $\begin{array}{c}{ }^{*} \text { Bulk Density } \\
(\mathrm{clod}) \\
\left(\mathrm{Mg} \mathrm{m}^{-3}\right)\end{array}$ \\
\hline Oi1 & $0-2$ & 0.00 & 0.05 & $\mathrm{~N} / \mathrm{A}$ \\
Oa \& A & $2-3$ & 1.34 & 0.08 & $\mathrm{~N} / \mathrm{A}$ \\
A & $3-8$ & 0.58 & 0.316 & 1 \\
BE & $8-15$ & 0.37 & $\mathrm{~N} / \mathrm{A}$ & 1.2 \\
Bw & $15-46$ & 3.69 & $\mathrm{~N} / \mathrm{A}$ & 1.6 \\
Bgx1 & $46-68$ & 14.61 & $\mathrm{~N} / \mathrm{A}$ & 1.8 \\
Bgx2 & $68-125$ & 7.98 & $\mathrm{~N} / \mathrm{A}$ & 1.9 \\
C & $125-150+$ & 1.01 & $\mathrm{~N} / \mathrm{A}$ & 1.9
\end{tabular}

*both bulk density procedures represent the $<2 \mathrm{~mm}$ fine earth fraction

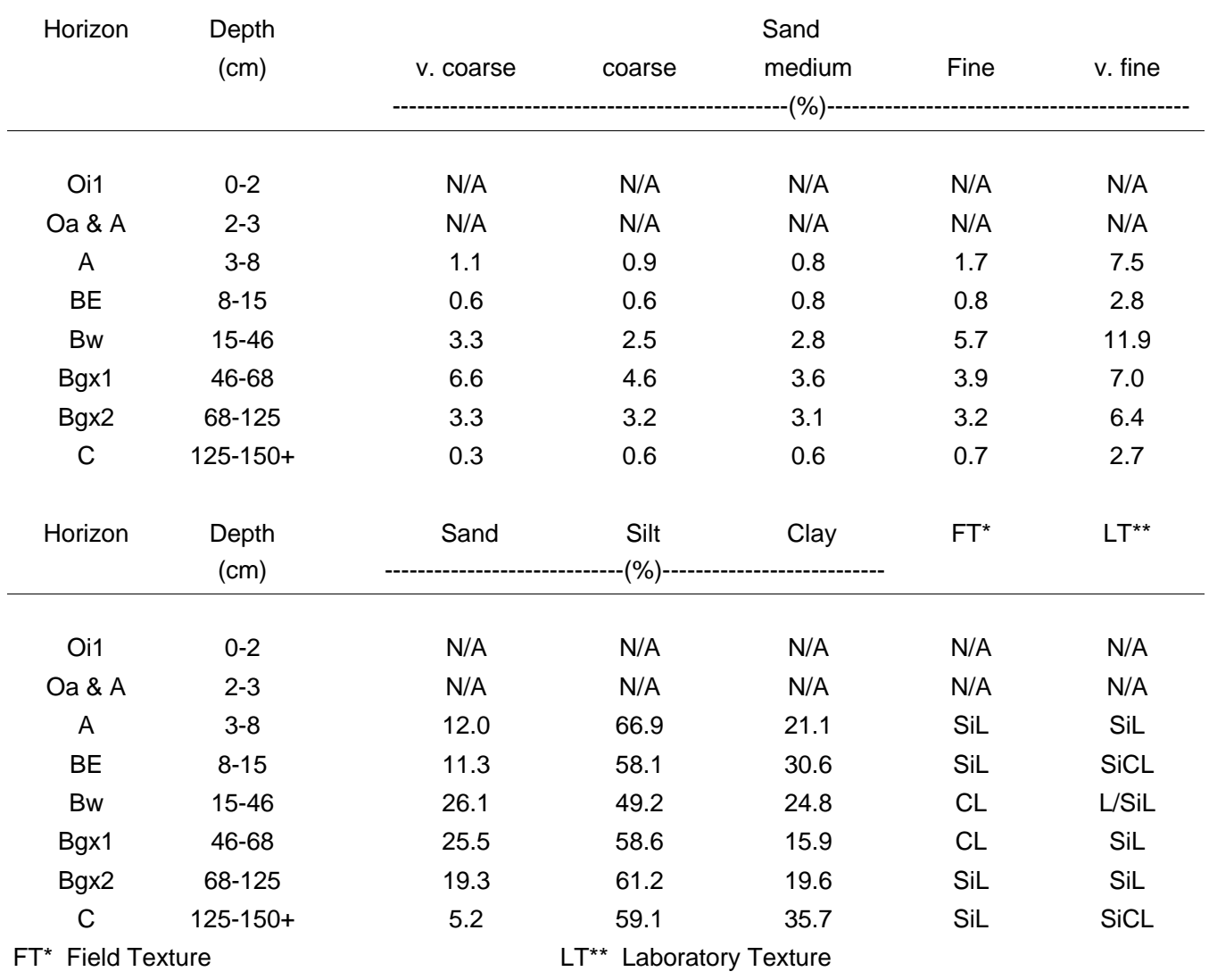




\section{Table 16. R2 Physical Data}

\begin{tabular}{ccccc} 
Horizon & Depth & $\begin{array}{c}\text { Rock } \\
\text { Fragments } \\
(\% \text { by wt. })\end{array}$ & $\begin{array}{c}\text { *Bulk Density } \\
\text { (frame) } \\
\left(\mathrm{Mg} \mathrm{m}^{-3}\right)\end{array}$ & $\begin{array}{c}\text { *Blk Density } \\
(\mathrm{clod}) \\
\left(\mathrm{Mg} \mathrm{m}^{-3}\right)\end{array}$ \\
\hline Oi1 & $0-1$ & 0.00 & 0.06 & $\mathrm{~N} / \mathrm{A}$ \\
Oi2 & $1-3$ & 0.00 & 0.09 & $\mathrm{~N} / \mathrm{A}$ \\
A & $3-10$ & 3.35 & 1.11 & 1.1 \\
AB & $10-16$ & 5.62 & 1.44 & 1.1 \\
Bw1 & $16-30$ & 6.44 & $\mathrm{~N} / \mathrm{A}$ & 1.5 \\
Bw2 & $30-44$ & 1.63 & $\mathrm{~N} / \mathrm{A}$ & 1.6 \\
Bw3 & $44-70$ & 1.32 & $\mathrm{~N} / \mathrm{A}$ & 1.8 \\
Bx & $70-110$ & 5.45 & $\mathrm{~N} / \mathrm{A}$ & 1.8 \\
C & $110-150+$ & 11.20 & $\mathrm{~N} / \mathrm{A}$ & 1.8
\end{tabular}

*both bulk density procedures represent the $<2 \mathrm{~mm}$ fine earth fraction

\begin{tabular}{|c|c|c|c|c|c|c|}
\hline Horizon & $\begin{array}{l}\text { Depth } \\
(\mathrm{cm})\end{array}$ & v. coarse & \multicolumn{3}{|c|}{ Sand } & v. fine \\
\hline Oi1 & $0-1$ & $\mathrm{~N} / \mathrm{A}$ & $\mathrm{N} / \mathrm{A}$ & $\mathrm{N} / \mathrm{A}$ & $N / A$ & $\mathrm{~N} / \mathrm{A}$ \\
\hline Oi2 & $1-3$ & $\mathrm{~N} / \mathrm{A}$ & $\mathrm{N} / \mathrm{A}$ & $\mathrm{N} / \mathrm{A}$ & $N / A$ & $\mathrm{~N} / \mathrm{A}$ \\
\hline A & $3-10$ & 1.9 & 2.4 & 5.1 & 9.6 & 10.3 \\
\hline$A B$ & $10-16$ & 0.7 & 2.4 & 5.6 & 10.0 & 10.6 \\
\hline Bw1 & $16-30$ & 0.8 & 3.5 & 7.5 & 11.3 & 11.6 \\
\hline Bw2 & $30-44$ & 0.9 & 3.5 & 8.0 & 11.5 & 11.7 \\
\hline Bw3 & $44-70$ & 1.5 & 2.8 & 6.1 & 10.5 & 11.6 \\
\hline $\mathrm{Bx}$ & $70-110$ & 1.4 & 3.0 & 5.2 & 6.4 & 8.8 \\
\hline C & $110-150+$ & 2.5 & 1.9 & 1.5 & 2.1 & 10.3 \\
\hline Horizon & $\begin{array}{l}\text { Depth } \\
(\mathrm{cm})\end{array}$ & Sand & $\begin{array}{r}\text { Silt } \\
---(\%)--\end{array}$ & Clay & $\mathrm{FT}^{*}$ & $\mathrm{LT}^{\star \star *}$ \\
\hline Oi1 & $0-1$ & $\mathrm{~N} / \mathrm{A}$ & $\mathrm{N} / \mathrm{A}$ & $\mathrm{N} / \mathrm{A}$ & $N / A$ & $N / A$ \\
\hline Oi2 & $1-3$ & $\mathrm{~N} / \mathrm{A}$ & $\mathrm{N} / \mathrm{A}$ & $\mathrm{N} / \mathrm{A}$ & $N / A$ & $\mathrm{~N} / \mathrm{A}$ \\
\hline A & $3-10$ & 30.6 & 53.2 & 16.3 & SiL & SiL \\
\hline$A B$ & $10-16$ & 29.7 & 49.8 & 20.6 & SiL & L/SiL \\
\hline Bw1 & $16-30$ & 34.8 & 43.7 & 21.4 & L & L \\
\hline Bw2 & $30-44$ & 35.6 & 43.7 & 20.7 & $L$ & L \\
\hline Bw3 & $44-70$ & 32.6 & 42.3 & 25.2 & $\mathrm{CL}$ & L \\
\hline $\mathrm{Bx}$ & $70-110$ & 25.0 & 47.2 & 27.8 & $\mathrm{CL}$ & CL/L \\
\hline C & $110-150+$ & 18.6 & 52.5 & 28.9 & L & $\mathrm{CL}$ \\
\hline $\mathrm{T}^{\star}$ Field $\mathrm{T}$ & & & ** Labor & Texture & & \\
\hline
\end{tabular}




\section{Table 17. R3 Physical Data}

\begin{tabular}{ccccc} 
Horizon & Depth & $\begin{array}{c}\text { Rock } \\
\text { Fragments } \\
(\% \text { by wt.) }\end{array}$ & $\begin{array}{c}\text { *Bulk Density } \\
(\text { frame }) \\
\left(\mathrm{Mg} \mathrm{m}^{-3}\right)\end{array}$ & $\begin{array}{c}\text { Bulk Density } \\
(\mathrm{clod}) \\
\left(\mathrm{Mg} \mathrm{m}^{-3}\right)\end{array}$ \\
\hline Oi1 & $0-1$ & 0.00 & 0.03 & $\mathrm{~N} / \mathrm{A}$ \\
Oi2 & $1-4$ & 0.00 & 0.03 & $\mathrm{~N} / \mathrm{A}$ \\
Oe & $4-7$ & 0.00 & 0.07 & $\mathrm{~N} / \mathrm{A}$ \\
Oa & $7-42$ & 26.12 & 0.21 & $\mathrm{~N} / \mathrm{A}$ \\
E & $42-55$ & 7.27 & $\mathrm{~N} / \mathrm{A}$ & 1.9 \\
Bt & $55-75$ & 4.67 & $\mathrm{~N} / \mathrm{A}$ & 1.8 \\
Btx & $75-120$ & 1.64 & $\mathrm{~N} / \mathrm{A}$ & 1.9 \\
$\mathrm{Cg}$ & $120-150+$ & 1.58 & $\mathrm{~N} / \mathrm{A}$ & 1.8
\end{tabular}

*both bulk density procedures represent the $<2 \mathrm{~mm}$ fine earth fraction

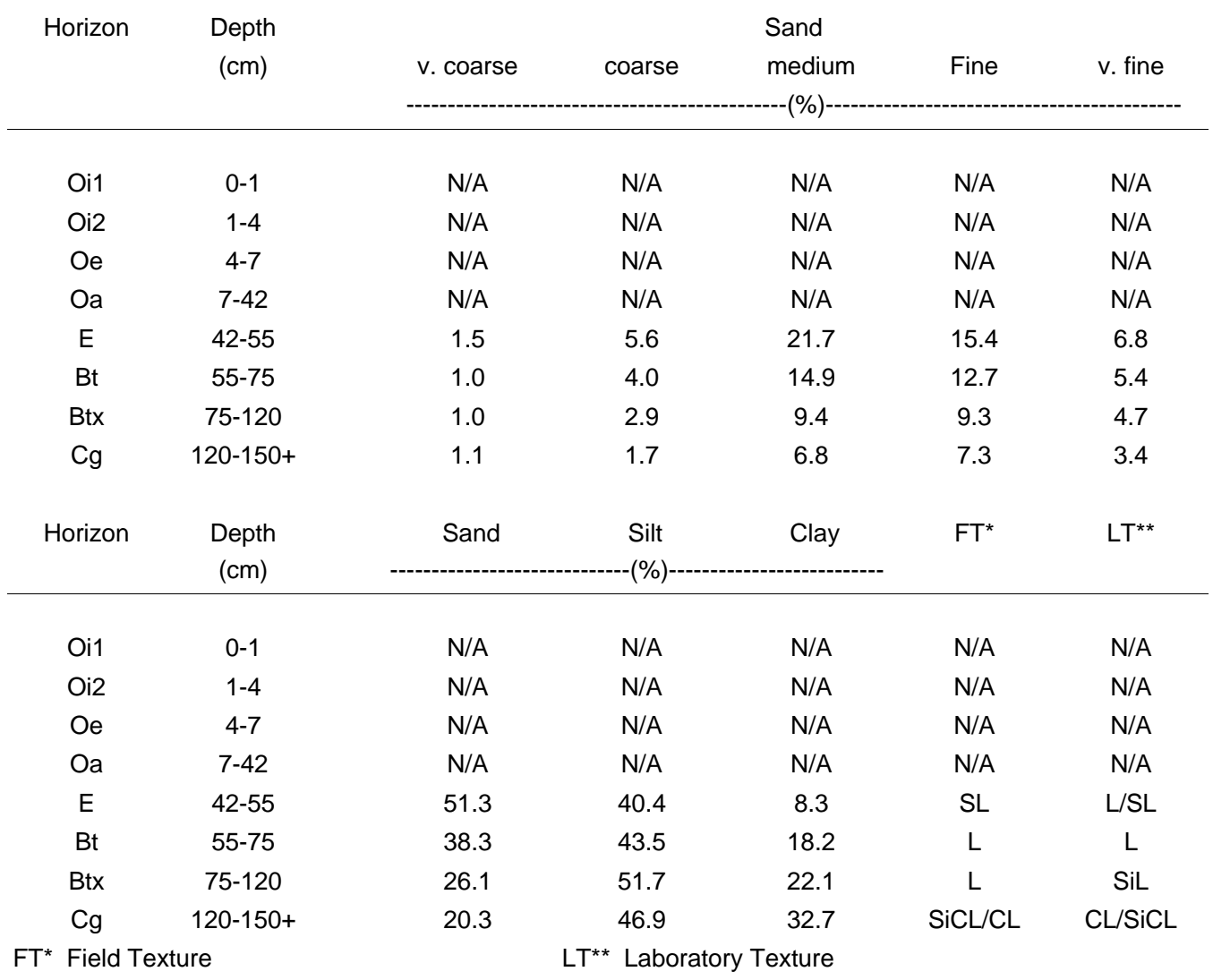




\section{Table 18. R4 Physical Data}

\begin{tabular}{ccccc} 
Horizon & Depth & $\begin{array}{c}\text { Rock } \\
\text { Fragments } \\
(\% \text { by wt.) }\end{array}$ & $\begin{array}{c}\text { * Bulk Density } \\
(\text { frame }) \\
\left(\mathrm{Mg} \mathrm{m}^{-3}\right)\end{array}$ & $\begin{array}{c}{ }^{*} \text { Bulk Density } \\
(\mathrm{clod}) \\
\left(\mathrm{Mg} \mathrm{m}^{-3}\right)\end{array}$ \\
\hline Oi1 & $1-0$ & 0.00 & 0.08 & $\mathrm{~N} / \mathrm{A}$ \\
Oi2 & $0-2$ & 0.00 & 0.10 & $\mathrm{~N} / \mathrm{A}$ \\
Oe & $2-4$ & $\mathrm{~N} / \mathrm{A}$ & $\mathrm{N} / \mathrm{A}$ & $\mathrm{N} / \mathrm{A}$ \\
Oa/A & $4-12$ & 25.82 & 0.71 & $\mathrm{~N} / \mathrm{A}$ \\
$\mathrm{Eg}$ & $12-20$ & 5.06 & 1.29 & 1.8 \\
$\mathrm{Bh}$ & $20-30$ & 10.69 & $\mathrm{~N} / \mathrm{A}$ & 1.6 \\
Bw & $30-44$ & 15.51 & $\mathrm{~N} / \mathrm{A}$ & 1.8 \\
$\mathrm{Bx}$ & $44-75$ & 7.91 & $\mathrm{~N} / \mathrm{A}$ & 2.0 \\
BCg & $75-100$ & 4.76 & $\mathrm{~N} / \mathrm{A}$ & 2.0 \\
$\mathrm{Cg}$ & $100-150+$ & 5.17 & $\mathrm{~N} / \mathrm{A}$ & 2.0
\end{tabular}

*both bulk density procedures represent the $<2 \mathrm{~mm}$ fine earth fraction

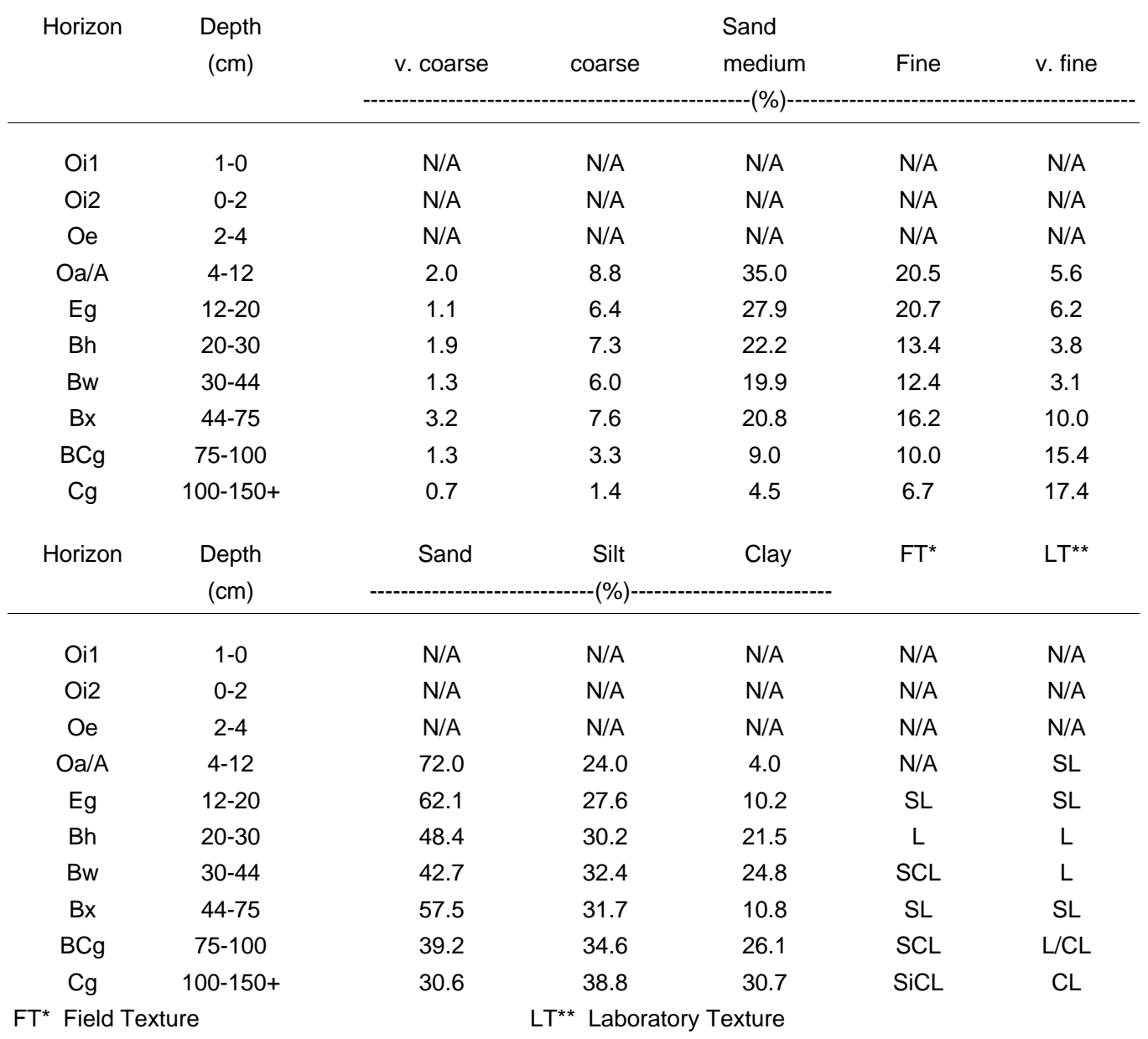




\section{Table 19. SSC1 Physical Data}

\begin{tabular}{|c|c|c|c|c|}
\hline Horizon & $\begin{array}{l}\text { Depth } \\
(\mathrm{cm})\end{array}$ & $\begin{array}{c}\text { Rock } \\
\text { Fragments } \\
\text { (\% by wt.) }\end{array}$ & $\begin{array}{c}\text { *Bulk Density } \\
\text { (frame) } \\
\left(\mathrm{Mg} \mathrm{m}^{-3}\right)\end{array}$ & $\begin{array}{l}{ }^{*} \text { Bulk Density } \\
\text { (clod) } \\
\left(\mathrm{Mg} \mathrm{m}^{-3}\right)\end{array}$ \\
\hline Oi1 & $0-3$ & 0.00 & ${ }^{* *} 0.03$ & $\mathrm{~N} / \mathrm{A}$ \\
\hline Oi2 & $3-6$ & 0.00 & ** & $\mathrm{N} / \mathrm{A}$ \\
\hline Oe & $6-8$ & 0.00 & 0.08 & $\mathrm{~N} / \mathrm{A}$ \\
\hline $\mathrm{Oa} / \mathrm{A}$ & $8-15$ & 0.00 & 0.63 & $\mathrm{~N} / \mathrm{A}$ \\
\hline $\mathrm{A} \circledast$ & $(15-76)$ & 62.72 & 0.95 & $\mathrm{~N} / \mathrm{A}$ \\
\hline$A / E$ & $15-30$ & 42.75 & $\mathrm{~N} / \mathrm{A}$ & N/A \\
\hline $\mathrm{BE}$ & $30-58$ & 51.55 & $\mathrm{~N} / \mathrm{A}$ & $N / A$ \\
\hline Bw & $58-89$ & 39.06 & $\mathrm{~N} / \mathrm{A}$ & 1.1 \\
\hline Bs ${ }^{\circledR}$ & $(76-89)$ & 40.38 & $\mathrm{~N} / \mathrm{A}$ & $\mathrm{N} / \mathrm{A}$ \\
\hline$B x$ & $89-125$ & 50.86 & $\mathrm{~N} / \mathrm{A}$ & 1.5 \\
\hline Cx & $125-170+$ & 47.48 & $\mathrm{~N} / \mathrm{A}$ & 1.9 \\
\hline
\end{tabular}

$\AA$ indicates that these horizons were only located on the right side of the pit and were not part of the pedon *both bulk density procedures represent the $<2 \mathrm{~mm}$ fine earth fraction **indicates that the Oi1 and Oi2 samples were collected and reported together for that soil's frame bulk density Horizon Depth Sand

\begin{tabular}{|c|c|c|c|c|c|c|}
\hline & $(\mathrm{cm})$ & v. coarse & coarse & medium & Fine & v. fine \\
\hline Oi1 & $0-3$ & $\mathrm{~N} / \mathrm{A}$ & $\mathrm{N} / \mathrm{A}$ & $\mathrm{N} / \mathrm{A}$ & $\mathrm{N} / \mathrm{A}$ & $\mathrm{N} / \mathrm{A}$ \\
\hline Oi2 & $3-6$ & $\mathrm{~N} / \mathrm{A}$ & $\mathrm{N} / \mathrm{A}$ & $\mathrm{N} / \mathrm{A}$ & $\mathrm{N} / \mathrm{A}$ & N/A \\
\hline $\mathrm{Oe}$ & $6-8$ & $\mathrm{~N} / \mathrm{A}$ & $\mathrm{N} / \mathrm{A}$ & $\mathrm{N} / \mathrm{A}$ & $\mathrm{N} / \mathrm{A}$ & N/A \\
\hline $\mathrm{Oa} / \mathrm{A}$ & $8-15$ & $\mathrm{~N} / \mathrm{A}$ & $\mathrm{N} / \mathrm{A}$ & $\mathrm{N} / \mathrm{A}$ & $\mathrm{N} / \mathrm{A}$ & N/A \\
\hline$A \circledast$ & $(15-76)$ & 6.1 & 4.2 & 9.4 & 13.76 & 12.9 \\
\hline$A / E$ & $15-30$ & 3.5 & 2.6 & 7.8 & 13.2 & 14.4 \\
\hline$B E$ & $30-58$ & 6.2 & 3.7 & 7.7 & 12.6 & 14.8 \\
\hline Bw & $58-89$ & 6.2 & 4.5 & 7.0 & 11.5 & 18.3 \\
\hline Bs $\AA^{\circledR}$ & $(76-89)$ & 14.0 & 7.0 & 8.7 & 13.0 & 17.3 \\
\hline$B x$ & $89-125$ & 6.2 & 4.7 & 7.1 & 11.6 & 14.0 \\
\hline$C x$ & $125-170+$ & 12.8 & 9.5 & 13.3 & 17.3 & 16.8 \\
\hline Horizon & $\begin{array}{c}\text { Depth } \\
\text { (cm) }\end{array}$ & Sand & $\begin{array}{c}\text { Silt } \\
-(\%)---\end{array}$ & Clay & $\mathrm{FT}^{*}$ & $\mathrm{LT}^{\star * *}$ \\
\hline Oi1 & $0-3$ & $\mathrm{~N} / \mathrm{A}$ & $\mathrm{N} / \mathrm{A}$ & $\mathrm{N} / \mathrm{A}$ & $\mathrm{N} / \mathrm{A}$ & $\mathrm{N} / \mathrm{A}$ \\
\hline Oi2 & $3-6$ & $\mathrm{~N} / \mathrm{A}$ & $\mathrm{N} / \mathrm{A}$ & $\mathrm{N} / \mathrm{A}$ & $\mathrm{N} / \mathrm{A}$ & $\mathrm{N} / \mathrm{A}$ \\
\hline $\mathrm{Oe}$ & $6-8$ & $\mathrm{~N} / \mathrm{A}$ & $\mathrm{N} / \mathrm{A}$ & $\mathrm{N} / \mathrm{A}$ & $\mathrm{N} / \mathrm{A}$ & N/A \\
\hline $\mathrm{Oa} / \mathrm{A}$ & $8-15$ & $\mathrm{~N} / \mathrm{A}$ & $\mathrm{N} / \mathrm{A}$ & $\mathrm{N} / \mathrm{A}$ & $\mathrm{N} / \mathrm{A}$ & $\mathrm{N} / \mathrm{A}$ \\
\hline$A \circledast$ & $(15-76)$ & 46.4 & 44.3 & 9.4 & $\mathrm{~N} / \mathrm{A}$ & L \\
\hline$A / E$ & $15-30$ & 41.8 & 46.1 & 12.1 & L & L \\
\hline $\mathrm{BE}$ & $30-58$ & 45.0 & 47.6 & 7.4 & SiL & L \\
\hline Bw & $58-89$ & 44.2 & 45.9 & 9.9 & SiL & L \\
\hline Bs ${ }^{\circledR}$ & $(76-89)$ & 59.8 & 38.9 & 1.3 & $\mathrm{~N} / \mathrm{A}$ & SL \\
\hline $\mathrm{Bx}$ & $89-125$ & 44.6 & 46.1 & 9.3 & L & L \\
\hline$C x$ & $125-170+$ & 69.0 & 30.3 & 0.6 & SL & SL \\
\hline
\end{tabular}

$\mathrm{FT}^{\star}$ Field Texture

$\mathrm{LT}^{\star \star}$ Laboratory Texture 


\section{Table 20. SSC2 Physical Data}

\begin{tabular}{ccccc} 
Horizon & Depth & $\begin{array}{c}\text { Rock } \\
\text { Fragments } \\
(\% \text { by wt. })\end{array}$ & $\begin{array}{c}\text { *Bulk Density } \\
\text { (frame) } \\
\left(\mathrm{Mg} \mathrm{m}^{-3}\right)\end{array}$ & $\begin{array}{c}{ }^{*} \text { Bulk Density } \\
(\mathrm{clod}) \\
\left(\mathrm{Mg} \mathrm{m}{ }^{-3}\right)\end{array}$ \\
\hline Oi1 & $0-2.5$ & 0.00 & 0.48 & $\mathrm{~N} / \mathrm{A}$ \\
A & $2.5-9$ & 12.82 & $\mathrm{~N} / \mathrm{A}$ & $\mathrm{N} / \mathrm{A}$ \\
BA & $9-30$ & 15.98 & $\mathrm{~N} / \mathrm{A}$ & 1.0 \\
Bt1 & $30-41$ & 55.18 & $\mathrm{~N} / \mathrm{A}$ & 1.3 \\
Bt2 & $41-61$ & 66.10 & $\mathrm{~N} / \mathrm{A}$ & 1.3 \\
BC & $61-79$ & 76.06 & $\mathrm{~N} / \mathrm{A}$ & 1.3 \\
C & $79-99$ & 86.95 & $\mathrm{~N} / \mathrm{A}$ & $\mathrm{N} / \mathrm{A}$
\end{tabular}

*both bulk density procedures represent the $<2 \mathrm{~mm}$ fine earth fraction

\begin{tabular}{|c|c|c|c|c|c|c|}
\hline Horizon & $\begin{array}{l}\text { Depth } \\
(\mathrm{cm})\end{array}$ & \multicolumn{5}{|c|}{ Sand } \\
\hline Oi1 & $0-2.5$ & $\mathrm{~N} / \mathrm{A}$ & $\mathrm{N} / \mathrm{A}$ & $\mathrm{N} / \mathrm{A}$ & N/A & $\mathrm{N} / \mathrm{A}$ \\
\hline A & $2.5-9$ & 0.6 & 1.4 & 0.6 & 1.5 & 8.7 \\
\hline BA & $9-30$ & 1.4 & 1.7 & 0.9 & 2.1 & 8.7 \\
\hline Bt1 & $30-41$ & 1.6 & 2.1 & 1.1 & 3.4 & 8.2 \\
\hline $\mathrm{Bt} 2$ & $41-61$ & 1.0 & 1.4 & 0.8 & 2.7 & 13.1 \\
\hline $\mathrm{BC}$ & $61-79$ & 0.9 & 1.0 & 0.6 & 1.7 & 11.4 \\
\hline C & $79-99$ & 3.4 & 2.8 & 1.6 & 3.0 & 10.2 \\
\hline Horizon & $\begin{array}{l}\text { Depth } \\
(\mathrm{cm})\end{array}$ & Sand & $\begin{array}{r}\text { Silt } \\
---(\%)--\end{array}$ & Clay & $\mathrm{FT}^{*}$ & $\mathrm{LT}^{* *}$ \\
\hline Oi1 & $0-2.5$ & $\mathrm{~N} / \mathrm{A}$ & $\mathrm{N} / \mathrm{A}$ & $\mathrm{N} / \mathrm{A}$ & N/A & $\mathrm{N} / \mathrm{A}$ \\
\hline A & $2.5-9$ & 13.0 & 62.6 & 24.5 & SiL & SiL \\
\hline BA & $9-30$ & 15.2 & 57.3 & 27.5 & SiL & SiCL/SiL \\
\hline $\mathrm{Bt} 1$ & $30-41$ & 17.0 & 62.6 & 20.4 & SiL & SiL \\
\hline $\mathrm{Bt} 2$ & $41-61$ & 19.4 & 61.9 & 18.7 & $\mathrm{SiL}$ & SiL \\
\hline$B C$ & $61-79$ & 15.6 & 68.0 & 16.3 & SiL & SiL \\
\hline C & $79-99$ & 21.6 & 70.2 & 8.2 & SiL & SiL \\
\hline $\mathrm{T}^{\star}$ Field $\mathrm{T}$ & & & ** Labor & Texture & & \\
\hline
\end{tabular}




\section{Table 21. SSC3 Physical Data}

\begin{tabular}{ccccc} 
Horizon & Depth & $\begin{array}{c}\text { Rock } \\
\text { Fragments } \\
(\% \text { by wt. })\end{array}$ & $\begin{array}{c}{ }^{*} \text { Bulk Density } \\
(\text { frame }) \\
\left(\mathrm{Mg} \mathrm{m}^{-3}\right)\end{array}$ & $\begin{array}{c}{ }^{*} \text { Bulk Density } \\
(\mathrm{clod}) \\
\left(\mathrm{Mg} \mathrm{m}^{-3}\right)\end{array}$ \\
\hline Oi1 & $2-0$ & 0.00 & 0.02 & $\mathrm{~N} / \mathrm{A}$ \\
Oi2 & $0-2$ & 0.00 & 0.08 & $\mathrm{~N} / \mathrm{A}$ \\
Oe & $2-6$ & 0.00 & 0.12 & $\mathrm{~N} / \mathrm{A}$ \\
Oa/A & $6-11$ & 70.26 & 0.38 & $\mathrm{~N} / \mathrm{A}$ \\
AB & $11-19$ & 65.67 & 0.87 & $\mathrm{~N} / \mathrm{A}$ \\
Bw1 & $19-35$ & 29.25 & $\mathrm{~N} / \mathrm{A}$ & 1.3 \\
Bw2 & $35-65$ & 35.86 & $\mathrm{~N} / \mathrm{A}$ & 1.3 \\
Bw3 & $65-85$ & 45.88 & $\mathrm{~N} / \mathrm{A}$ & 1.2 \\
BC & $85-113$ & 41.96 & $\mathrm{~N} / \mathrm{A}$ & 1.1 \\
C1 & $113-138$ & 44.86 & $\mathrm{~N} / \mathrm{A}$ & 1.5 \\
C2 & $138-160+$ & 46.79 & $\mathrm{~N} / \mathrm{A}$ & $\mathrm{N} / \mathrm{A}$
\end{tabular}

*both bulk density procedures represent the $<2 \mathrm{~mm}$ fine earth fraction

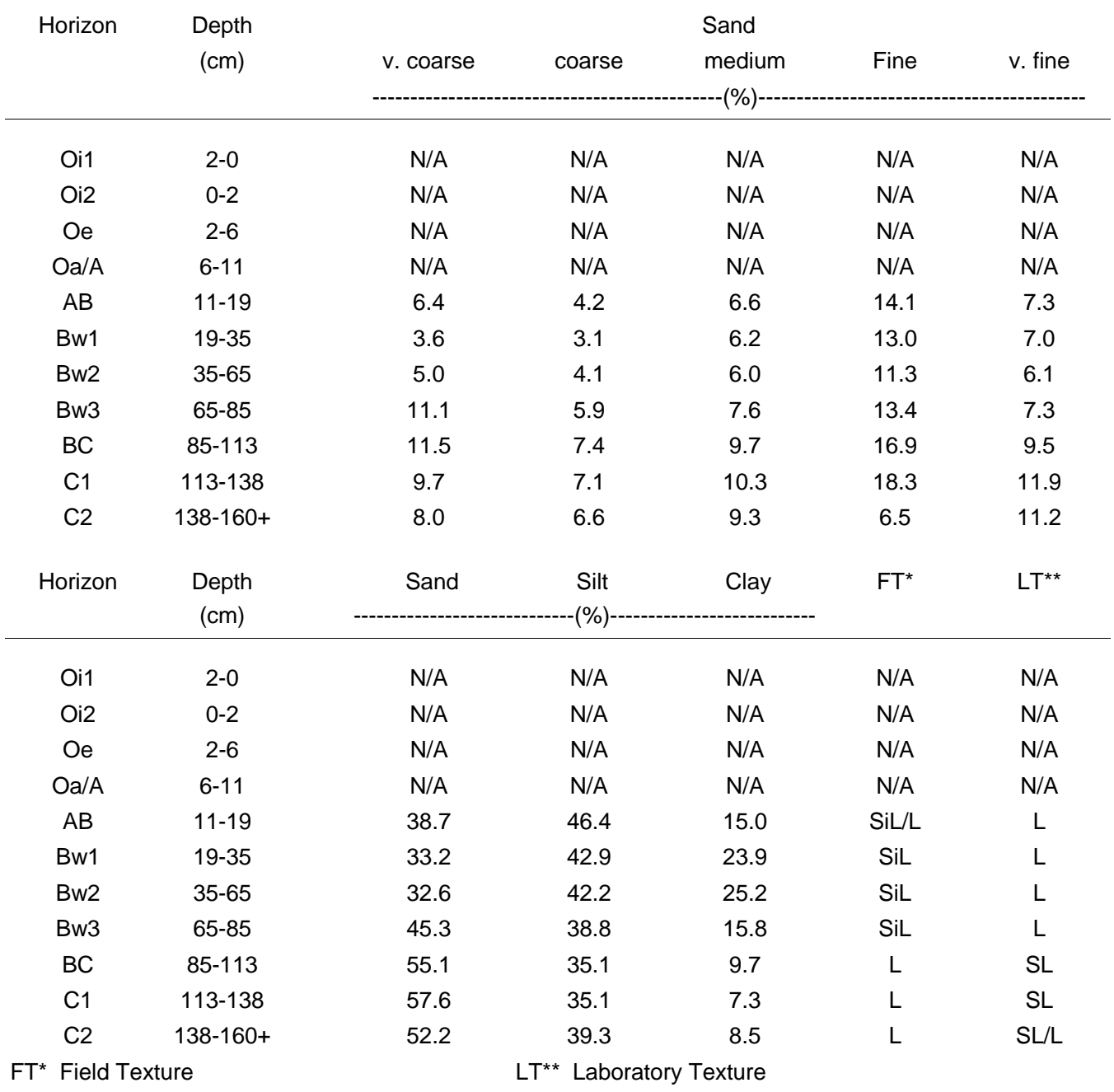




\section{Table 22. SSA1 Physical Data}

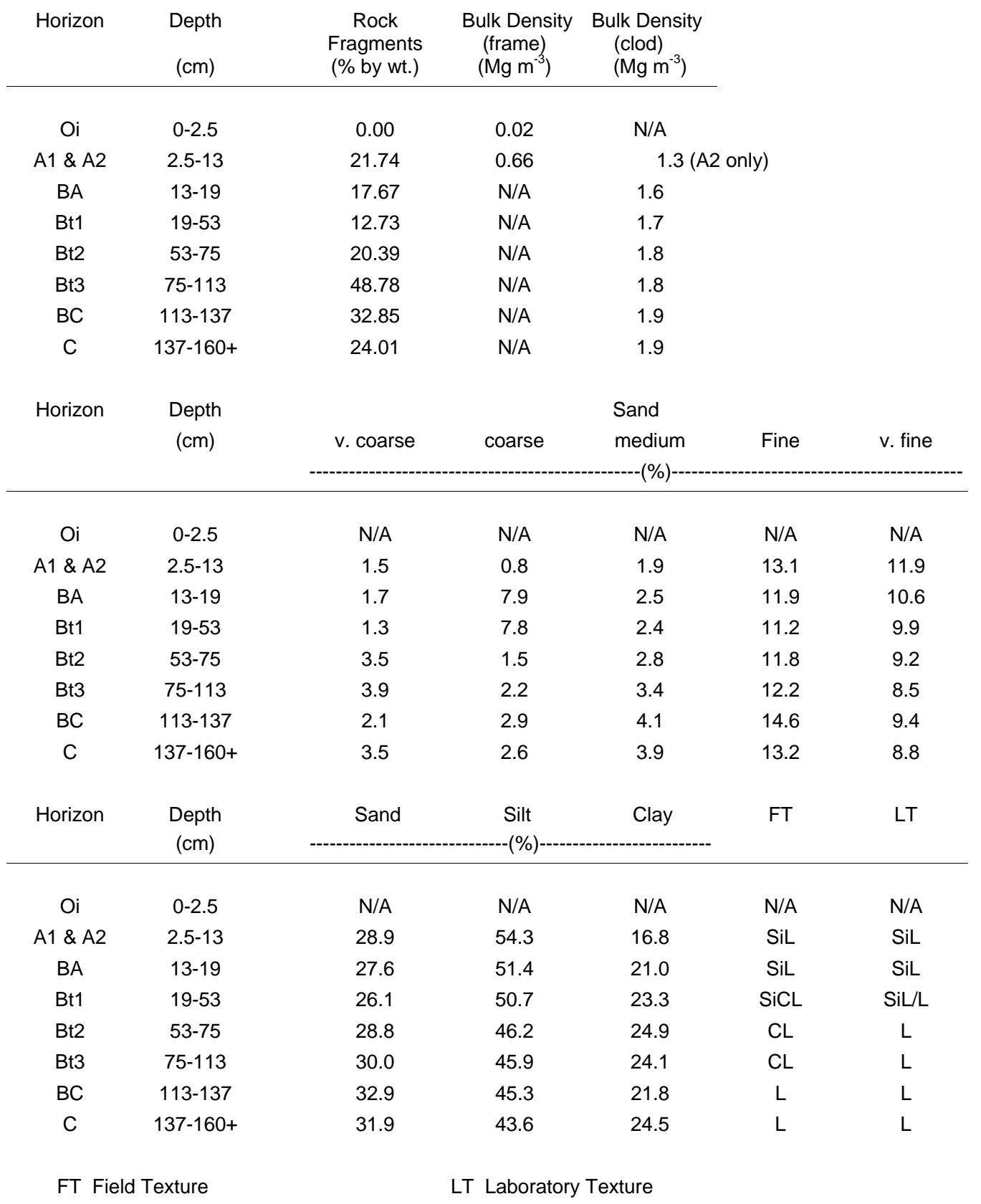




\section{Table 23. SSA2 Physical Data}

\begin{tabular}{ccccc} 
Horizon & Depth & $\begin{array}{c}\text { Rock } \\
\text { Fragments } \\
(\% \text { by wt. })\end{array}$ & $\begin{array}{c}* \text { Bulk Density } \\
(\text { frame }) \\
\left(\mathrm{Mg} \mathrm{m}^{-3}\right)\end{array}$ & $\begin{array}{c}{ }^{*} \text { Bulk Density } \\
(\mathrm{clod}) \\
\left(\mathrm{Mg} \mathrm{m}^{-3}\right)\end{array}$ \\
\hline Oi1 & $0-1$ & 0.00 & ${ }^{* *} 0.03$ & $\mathrm{~N} / \mathrm{A}$ \\
Oi2 & $1-3$ & 0.00 & $* *$ & $\mathrm{~N} / \mathrm{A}$ \\
A & $3-14$ & 48.16 & 0.36 & $\mathrm{~N} / \mathrm{A}$ \\
BA & $14-34$ & 24.38 & 0.57 & $\mathrm{~N} / \mathrm{A}$ \\
Bt1 & $34-60$ & 19.80 & $\mathrm{~N} / \mathrm{A}$ & 1.6 \\
Bt2 & $60-107$ & 30.63 & $\mathrm{~N} / \mathrm{A}$ & 1.7 \\
BC & $107-138$ & 13.97 & $\mathrm{~N} / \mathrm{A}$ & 2.0 \\
C & $138-152$ & 13.59 & $\mathrm{~N} / \mathrm{A}$ & 1.8
\end{tabular}

*both bulk density procedures represent the $<2 \mathrm{~mm}$ fine earth fraction

**indicates that the Oi1 and Oi2 samples were collected and reported together for that soil's frame bulk density

\begin{tabular}{|c|c|c|c|c|c|c|}
\hline Horizon & $\begin{array}{l}\text { Depth } \\
(\mathrm{cm})\end{array}$ & v. coarse & coarse & $\begin{array}{l}\text { Sand } \\
\text { medium }\end{array}$ & Fine & v. fine \\
\hline Oi1 & $0-1$ & $\mathrm{~N} / \mathrm{A}$ & $\mathrm{N} / \mathrm{A}$ & $\mathrm{N} / \mathrm{A}$ & $\mathrm{N} / \mathrm{A}$ & $\mathrm{N} / \mathrm{A}$ \\
\hline Oi2 & $1-3$ & $\mathrm{~N} / \mathrm{A}$ & $\mathrm{N} / \mathrm{A}$ & $\mathrm{N} / \mathrm{A}$ & $\mathrm{N} / \mathrm{A}$ & $\mathrm{N} / \mathrm{A}$ \\
\hline$A$ & $3-14$ & 6.0 & 1.7 & 0.7 & 3.2 & 11.5 \\
\hline BA & $14-34$ & 5.6 & 2.0 & 1.0 & 3.0 & 10.4 \\
\hline Bt1 & $34-60$ & 4.8 & 3.1 & 1.4 & 2.7 & 8.5 \\
\hline $\mathrm{Bt} 2$ & $60-107$ & 4.5 & 2.8 & 1.2 & 2.6 & 7.1 \\
\hline$B C$ & $107-138$ & 2.1 & 1.9 & 1.0 & 2.1 & 6.3 \\
\hline C & $138-152$ & 1.8 & 1.5 & 0.8 & 1.9 & 6.9 \\
\hline Horizon & $\begin{array}{l}\text { Depth } \\
(\mathrm{cm})\end{array}$ & Sand & $\begin{array}{c}\text { Silt } \\
--(\%)--\end{array}$ & Clay & $\mathrm{FT}$ & LT \\
\hline Oi1 & $0-1$ & $\mathrm{~N} / \mathrm{A}$ & $\mathrm{N} / \mathrm{A}$ & $\mathrm{N} / \mathrm{A}$ & $\mathrm{N} / \mathrm{A}$ & $\mathrm{N} / \mathrm{A}$ \\
\hline Oi2 & $1-3$ & $\mathrm{~N} / \mathrm{A}$ & $\mathrm{N} / \mathrm{A}$ & $\mathrm{N} / \mathrm{A}$ & $\mathrm{N} / \mathrm{A}$ & $\mathrm{N} / \mathrm{A}$ \\
\hline A & $3-14$ & 23.3 & 63.1 & 13.6 & SiL & SiL \\
\hline BA & $14-34$ & 22.3 & 58.8 & 18.9 & SiL & SiL \\
\hline Bt1 & $34-60$ & 20.5 & 54.9 & 24.6 & SiCL & SiL \\
\hline $\mathrm{Bt} 2$ & $60-107$ & 18.6 & 61.3 & 20.1 & SiL & SiL \\
\hline$B C$ & $107-138$ & 13.7 & 65.8 & 20.5 & SiL & SiL \\
\hline C & $138-152$ & 13.1 & 70.1 & 16.8 & SiL & SiL \\
\hline \multicolumn{2}{|c|}{ FT $^{\star}$ Field Texture } & \multicolumn{4}{|c|}{$\mathrm{LT}^{\star \star}$ Laboratory Texture } & \\
\hline
\end{tabular}




\section{Table 24. SSA3 Physical Data}

\begin{tabular}{ccccc} 
Horizon & Depth & $\begin{array}{c}\text { Rock } \\
\text { Fragments } \\
(\% \text { by wt.) }\end{array}$ & $\begin{array}{c}\text { *Bulk Density } \\
\text { (frame) } \\
\left(\mathrm{Mg} \mathrm{m}^{-3}\right)\end{array}$ & $\begin{array}{c}{ }^{*} \text { Bulk Density } \\
\text { (clod) } \\
\left(\mathrm{Mg} \mathrm{m}^{-3}\right)\end{array}$ \\
\hline Oi & $\mathrm{N} / \mathrm{A}$ & 0.00 & 0.50 & $\mathrm{~N} / \mathrm{A}$ \\
$\mathrm{O}^{*}$ & $\mathrm{~N} / \mathrm{A}$ & 0.00 & $\mathrm{~N} / \mathrm{A}$ & $\mathrm{N} / \mathrm{A}$ \\
$\mathrm{A} 1$ \& A2 & $0-7$ & 31.74 & 1.09 & $\mathrm{~N} / \mathrm{A}$ \\
$\mathrm{AB}$ & $7-12$ & 29.74 & 0.57 & 1.0 \\
$\mathrm{BA}$ & $12-29$ & 14.75 & $\mathrm{~N} / \mathrm{A}$ & 1.2 \\
$\mathrm{Bt}$ & $29-65$ & 48.59 & $\mathrm{~N} / \mathrm{A}$ & 1.4 \\
$\mathrm{BC}$ & $65-86$ & 55.86 & $\mathrm{~N} / \mathrm{A}$ & 1.5 \\
$\mathrm{C}$ & $86-101$ & 65.77 & $\mathrm{~N} / \mathrm{A}$ & 1.5
\end{tabular}

*both bulk density procedures represent the $<2 \mathrm{~mm}$ fine earth fraction

\begin{tabular}{|c|c|c|c|c|c|c|}
\hline \multirow[t]{2}{*}{ Horizon } & \multirow[t]{2}{*}{$\begin{array}{l}\text { Depth } \\
(\mathrm{cm})\end{array}$} & \multicolumn{5}{|c|}{ Sand } \\
\hline & & \multicolumn{5}{|c|}{-------------------------------------------------(\%)--- } \\
\hline Oi & $\mathrm{N} / \mathrm{A}$ & $\mathrm{N} / \mathrm{A}$ & $\mathrm{N} / \mathrm{A}$ & $\mathrm{N} / \mathrm{A}$ & $N / A$ & N/A \\
\hline $\mathrm{O}^{*}$ & $\mathrm{~N} / \mathrm{A}$ & $\mathrm{N} / \mathrm{A}$ & $\mathrm{N} / \mathrm{A}$ & $\mathrm{N} / \mathrm{A}$ & $N / A$ & $\mathrm{~N} / \mathrm{A}$ \\
\hline$A 1 \& A 2$ & $0-7$ & 0.6 & 0.6 & 0.7 & 5.1 & 13.4 \\
\hline$A B$ & $7-12$ & 1.4 & 1.0 & 0.7 & 4.6 & 11.9 \\
\hline $\mathrm{BA}$ & $12-29$ & 0.7 & 0.7 & 0.7 & 4.3 & 11.7 \\
\hline $\mathrm{Bt}$ & $29-65$ & 3.4 & 2.4 & 1.3 & 1.9 & 6.7 \\
\hline $\mathrm{BC}$ & $65-86$ & 0.6 & 0.9 & 0.5 & 0.8 & 8.9 \\
\hline C & 86-101 & 1.5 & 0.9 & 0.2 & 0.5 & 7.4 \\
\hline Horizon & $\begin{array}{c}\text { Depth } \\
(\mathrm{cm})\end{array}$ & \multicolumn{4}{|c|}{-------------------------------(\%)-------------------------- } & $\mathrm{LT}^{\star *}$ \\
\hline Oi & $\mathrm{N} / \mathrm{A}$ & $\mathrm{N} / \mathrm{A}$ & $\mathrm{N} / \mathrm{A}$ & $\mathrm{N} / \mathrm{A}$ & $N / A$ & N/A \\
\hline $\mathrm{O}^{*}$ & $\mathrm{~N} / \mathrm{A}$ & $\mathrm{N} / \mathrm{A}$ & $\mathrm{N} / \mathrm{A}$ & $\mathrm{N} / \mathrm{A}$ & $N / A$ & $\mathrm{~N} / \mathrm{A}$ \\
\hline$A 1 \& A 2$ & $0-7$ & 21.1 & 71.3 & 7.6 & $\mathrm{SiL}$ & SiL \\
\hline$A B$ & $7-12$ & 20.3 & 67.1 & 12.5 & SiL & SiL \\
\hline BA & $12-29$ & 18.9 & 64.5 & 16.6 & $\mathrm{SiL}$ & SiL \\
\hline $\mathrm{Bt}$ & $29-65$ & 15.6 & 62.8 & 21.7 & SiL & SiL \\
\hline $\mathrm{BC}$ & $65-86$ & 12.0 & 66.1 & 21.9 & $\mathrm{SiL}$ & SiL \\
\hline C & $86-101$ & 11.3 & 73.5 & 15.3 & SiL & SiL \\
\hline \multicolumn{3}{|c|}{ FT* Field Texture $^{*}$} & \multicolumn{4}{|c|}{$\mathrm{LT}^{\star *}$ Laboratory Texture } \\
\hline
\end{tabular}

* this horizon was labeled as an Oa but it clearly was not. More likely an Oi2 


\section{APPENDIX C \\ CHEMICAL DATA FOR EACH PEDON}

(Note: All horizon designations are shown how they appeared on the field description sheet). 


\section{Table 25. T1 Chemical Data}

\begin{tabular}{|c|c|c|c|c|c|c|c|c|}
\hline \multirow[t]{2}{*}{ Horizon } & \multirow{2}{*}{$\begin{array}{l}\text { Depth } \\
(\mathrm{cm})\end{array}$} & \multicolumn{2}{|c|}{$\mathrm{pH}$ (soil : solution) } & \multirow{2}{*}{$\begin{array}{c}\text { EC } \\
1: 2 \text { water } \\
\text { mmhos } \mathrm{cm}^{-1}\end{array}$} & \multirow[t]{2}{*}{ Total C } & \multirow[t]{2}{*}{ Total N } & \multirow[t]{2}{*}{ Total S } & \\
\hline & & 1: 1 water & $1: 2 \mathrm{CaCl}_{2}$ & & & & & \\
\hline $\mathrm{Oi} 1$ \& Oi2 & $0-3$ & $3.6(5)$ & $3(10)$ & $0.25(8)$ & 30.1 & 0.7 & 0.1 & \\
\hline $\mathrm{Oe}$ & $3-7$ & $3.3(5)$ & $2.6(10)$ & $0.33(8)$ & 43.4 & 1.4 & 0.2 & \\
\hline $\mathrm{Oa}$ & $7-15$ & $3.4(3)$ & $2.6(6)$ & $0.38(3)$ & 22.4 & 0.7 & 0.1 & \\
\hline$E$ & $15-25$ & 3.5 & 3.1 & 0.13 & 1.2 & $\operatorname{tr}$ & $\operatorname{tr}$ & \\
\hline EB g & $25-34$ & 3.7 & 3.2 & 0.10 & 0.8 & $\operatorname{tr}$ & $\operatorname{tr}$ & \\
\hline $\mathrm{Bg} 1$ & $34-51$ & 4.0 & 3.5 & 0.07 & 0.8 & $\operatorname{tr}$ & $\operatorname{tr}$ & \\
\hline $\mathrm{Bg} 2$ & $51-69$ & 4.3 & 4.0 & 0.05 & 0.4 & $\operatorname{tr}$ & $\operatorname{tr}$ & \\
\hline $\mathrm{BC}$ & $69-85$ & 4.7 & 4.3 & 0.05 & 0.4 & $\operatorname{tr}$ & $\operatorname{tr}$ & \\
\hline $\mathrm{Cg} 1$ & $85-110$ & 3.7 & 3.3 & 0.81 & 0.5 & $\operatorname{tr}$ & 0.1 & \\
\hline $\mathrm{Cg} 2$ & $110-121$ & 3.9 & 3.6 & 0.55 & 0.4 & $\operatorname{tr}$ & 0.1 & \\
\hline Cg3 & $121-160+$ & 4.0 & 3.7 & 0.28 & 0.4 & $\operatorname{tr}$ & $\operatorname{tr}$ & \\
\hline \multirow[t]{3}{*}{ Horizon } & Depth & \multicolumn{6}{|c|}{ Extractable } & \\
\hline & $(\mathrm{cm})$ & $\mathrm{Al}$ & Acidity & $\mathrm{Ca}$ & $\mathrm{Mg}$ & $\mathrm{Na}$ & $\mathrm{K}$ & Ca:Al \\
\hline & & \multicolumn{6}{|c|}{ 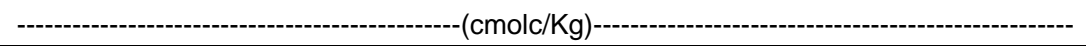 } & \\
\hline Oi1 \& Oi2 & $0-3$ & $N / A$ & $\mathrm{~N} / \mathrm{A}$ & $N / A$ & $N / A$ & $N / A$ & $\mathrm{~N} / \mathrm{A}$ & $\mathrm{N} / \mathrm{A}$ \\
\hline $\mathrm{Oe}$ & $3-7$ & $\operatorname{tr}$ & 111.7 & 5.1 & 1.1 & $\operatorname{tr}$ & 0.5 & 101.0 \\
\hline $\mathrm{Oa}$ & $7-15$ & 5.6 & 99.4 & 0.4 & 0.3 & $\operatorname{tr}$ & 0.2 & 0.1 \\
\hline$E$ & $15-25$ & 7.6 & 18.7 & $\operatorname{tr}$ & $\operatorname{tr}$ & $\operatorname{tr}$ & $\operatorname{tr}$ & 0.0 \\
\hline $\mathrm{EB} g$ & $25-34$ & 8.2 & 17.7 & $\operatorname{tr}$ & $\operatorname{tr}$ & $\operatorname{tr}$ & 0.1 & 0.0 \\
\hline $\mathrm{Bg} 1$ & $34-51$ & 9.6 & 18.7 & $\operatorname{tr}$ & $\operatorname{tr}$ & $\operatorname{tr}$ & 0.1 & 0.0 \\
\hline $\mathrm{Bg} 2$ & $51-69$ & 7.7 & 14.1 & 0.1 & 0.1 & $\operatorname{tr}$ & 0.1 & 0.0 \\
\hline $\mathrm{BC}$ & $69-85$ & 0.5 & 6.9 & 0.8 & 0.8 & $\operatorname{tr}$ & 0.1 & 1.5 \\
\hline $\mathrm{Cg} 1$ & $85-110$ & 1.1 & 7.3 & 1.1 & 0.8 & $\operatorname{tr}$ & 0.1 & 0.9 \\
\hline $\mathrm{Cg} 2$ & $110-121$ & 0.6 & 6.6 & 1.0 & 0.6 & $\operatorname{tr}$ & 0.1 & 1.7 \\
\hline $\mathrm{Cg} 3$ & $121-160+$ & 0.6 & 5.2 & 0.9 & 0.5 & $\operatorname{tr}$ & 0.1 & 1.5 \\
\hline \multirow[t]{2}{*}{ Horizon } & Depth & BS & $\begin{array}{c}\text { CEC Activity } \\
\text { Ratio }\end{array}$ & ECEC & Apparent CEC & $\begin{array}{c}\text { CEC } \\
(\mathrm{NH} 4 \mathrm{OAc})\end{array}$ & $\begin{array}{c}\text { CEC } \\
\text { (summation) }\end{array}$ & BSECEC \\
\hline & $(\mathrm{cm})$ & $(\%)$ & & $\left(\mathrm{cmol}_{\mathrm{C}} / \mathrm{Kg}\right)$ & $\left(\mathrm{cmol}_{\mathrm{C}} / \mathrm{Kg}\right.$ clay $)$ & \multicolumn{2}{|c|}{ 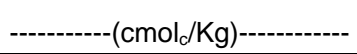 } & $(\%)$ \\
\hline Oi1 \& Oi2 & $0-3$ & $\mathrm{~N} / \mathrm{A}$ & $\mathrm{N} / \mathrm{A}$ & $N / A$ & $N / A$ & $\mathrm{~N} / \mathrm{A}$ & $\mathrm{N} / \mathrm{A}$ & $\mathrm{N} / \mathrm{A}$ \\
\hline $\mathrm{Oe}$ & $3-7$ & 5.7 & $\mathrm{~N} / \mathrm{A}$ & 6.7 & $N / A$ & 118.8 & 118.4 & 100.0 \\
\hline $\mathrm{Oa}$ & $7-15$ & 0.9 & $\mathrm{~N} / \mathrm{A}$ & 6.5 & $\mathrm{~N} / \mathrm{A}$ & 72.5 & 100.3 & 13.9 \\
\hline$E$ & $15-25$ & $\operatorname{tr}$ & $\mathrm{N} / \mathrm{A}$ & 7.6 & $\mathrm{~N} / \mathrm{A}$ & 13.4 & 18.7 & $\operatorname{tr}$ \\
\hline $\mathrm{EB} g$ & $25-34$ & 0.6 & 2.7 & 8.3 & 265.8 & 12.9 & 17.8 & 1.2 \\
\hline $\mathrm{Bg} 1$ & $34-51$ & 0.5 & 1.3 & 9.7 & 128.2 & 12.2 & 18.8 & 1.0 \\
\hline $\mathrm{Bg} 2$ & $51-69$ & 2.1 & 1.7 & 7.8 & 168.7 & 9.9 & 14.4 & 3.8 \\
\hline $\mathrm{BC}$ & $69-85$ & 19.8 & 2.3 & 2.2 & 233.3 & 4.6 & 8.6 & 77.3 \\
\hline $\mathrm{Cg} 1$ & $85-110$ & 21.5 & 5.2 & 3.1 & 516.5 & 4.4 & 9.3 & 64.5 \\
\hline $\mathrm{Cg} 2$ & $110-121$ & 20.5 & 2.1 & 2.3 & 213.5 & 4.0 & 8.3 & 73.9 \\
\hline Cg3 & $121-160+$ & 22.4 & 8.1 & 2.1 & 809.2 & 3.3 & 6.7 & 71.4 \\
\hline \multicolumn{2}{|c|}{ BS Base Saturation } & \multicolumn{6}{|c|}{ CEC Cation Exchange Capacity } & \\
\hline
\end{tabular}




\section{Table 25 continued}




Table 26. T2 Chemical Data

\begin{tabular}{|c|c|c|c|c|c|c|c|}
\hline \multirow[t]{2}{*}{ Horizon } & \multirow{2}{*}{$\begin{array}{l}\text { Depth } \\
(\mathrm{cm})\end{array}$} & \multicolumn{2}{|c|}{$\mathrm{pH}$ (soil : solution) } & \multirow{2}{*}{$\begin{array}{c}\text { EC } \\
\text { 1:2 water } \\
\text { mmhos } \mathrm{cm}^{-1}\end{array}$} & \multirow[t]{2}{*}{ Total C } & \multirow[t]{2}{*}{ Total N } & \multirow[t]{2}{*}{ Total S } \\
\hline & & 1: 1 water & $1: 2 \mathrm{CaCl}_{2}$ & & & & \\
\hline Oi & $0-2$ & $3.7(5)^{*}$ & $3.1(10)^{\star}$ & $0.41(8)^{*}$ & 45.2 & 1.0 & 0.1 \\
\hline $\mathrm{Oe}$ & $2-6$ & $3.4(5)^{*}$ & $2.8(10)^{*}$ & $0.43(6)^{*}$ & 42.2 & 1.3 & 0.2 \\
\hline $\mathrm{Oa}$ & $6-12$ & $3.3(3)^{*}$ & $2.6(6)^{*}$ & $0.40(4)^{*}$ & 26.5 & 0.7 & 0.1 \\
\hline EA & $12-17$ & 3.5 & 3.1 & 0.13 & 1.1 & $\operatorname{tr}$ & $\operatorname{tr}$ \\
\hline$E$ & $30-41$ & 3.7 & 3.2 & 0.07 & 0.3 & $\operatorname{tr}$ & $\operatorname{tr}$ \\
\hline Bw & $41-61$ & 4.1 & 3.6 & 0.04 & 0.5 & $\operatorname{tr}$ & $\operatorname{tr}$ \\
\hline $\mathrm{BCg}$ & $61-79$ & 4.5 & 3.8 & 0.03 & 0.5 & $\operatorname{tr}$ & $\operatorname{tr}$ \\
\hline C & $79-99$ & 4.6 & 3.9 & 0.04 & 0.4 & $\operatorname{tr}$ & $\operatorname{tr}$ \\
\hline $\mathrm{Cg}$ & $101-150+$ & 4.5 & 3.8 & 0.07 & 0.7 & $\operatorname{tr}$ & $\operatorname{tr}$ \\
\hline
\end{tabular}

*samples containing high OM content required higher dilutions than 1:1 or 1:2 (ex. 1 soil:4 water)

\begin{tabular}{|c|c|c|c|c|c|c|c|c|}
\hline \multirow[t]{2}{*}{ Horizon } & \multirow{2}{*}{$\begin{array}{l}\text { Depth } \\
(\mathrm{cm})\end{array}$} & \multicolumn{6}{|c|}{ Extractable } & \multirow[b]{2}{*}{ Ca:Al } \\
\hline & & $\mathrm{Al}$ & Acidity & $\mathrm{Ca}$ & $\mathrm{Mg}$ & $\mathrm{Na}$ & $\mathrm{K}$ & \\
\hline Oi & $0-2$ & $N / A$ & $\mathrm{~N} / \mathrm{A}$ & $\mathrm{N} / \mathrm{A}$ & $\mathrm{N} / \mathrm{A}$ & $\mathrm{N} / \mathrm{A}$ & $\mathrm{N} / \mathrm{A}$ & $\mathrm{N} / \mathrm{A}$ \\
\hline $\mathrm{Oe}$ & $2-6$ & $\operatorname{tr}$ & 107.2 & 5.2 & 0.6 & 0.1 & 0.6 & 104.3 \\
\hline $\mathrm{Oa}$ & $6-12$ & 2.9 & 104.7 & 1.7 & 0.3 & 0.1 & 0.2 & 0.6 \\
\hline EA & $12-17$ & 0.1 & 9.2 & $\operatorname{tr}$ & $\operatorname{tr}$ & $\operatorname{tr}$ & $\operatorname{tr}$ & 0.4 \\
\hline$E$ & $30-41$ & 0.7 & 6.2 & $\operatorname{tr}$ & $\operatorname{tr}$ & $\operatorname{tr}$ & $\operatorname{tr}$ & 0.1 \\
\hline Bw & $41-61$ & 3.9 & 12.5 & 0.1 & $\operatorname{tr}$ & $\operatorname{tr}$ & 0.1 & 0.0 \\
\hline $\mathrm{BCg}$ & $61-79$ & 1.5 & 7.5 & 0.1 & $\operatorname{tr}$ & $\operatorname{tr}$ & $\operatorname{tr}$ & 0.0 \\
\hline C & $79-99$ & 1.1 & 7.4 & 0.1 & 0.1 & $\operatorname{tr}$ & $\operatorname{tr}$ & 0.1 \\
\hline $\mathrm{Cg}$ & $101-150+$ & 2.2 & 9.7 & 0.6 & 0.5 & $\operatorname{tr}$ & 0.1 & 0.3 \\
\hline Horizon & $\begin{array}{l}\text { Depth } \\
(\mathrm{cm})\end{array}$ & $\begin{array}{l}\mathrm{BS}^{*} \\
(\%)\end{array}$ & $\begin{array}{l}\text { CEC Activity } \\
\text { Ratio }\end{array}$ & $\begin{array}{c}\mathrm{ECEC}^{* *} \\
\left(\mathrm{cmol}_{\mathrm{C}} / \mathrm{Kg}\right)\end{array}$ & $\begin{array}{l}\text { Apparent CEC } \\
\text { (cmol } / \mathrm{Kg} \text { clay) }\end{array}$ & $\begin{array}{c}\mathrm{CEC}^{* * *} \\
(\mathrm{NH} 4 \mathrm{OAc}) \\
-----(\mathrm{cmol}\end{array}$ & $\begin{array}{c}\text { CEC }{ }^{* * *} \\
\text { (summation) } \\
\mathrm{I}_{\mathrm{c}} / \mathrm{Kg} \text { )---------- }\end{array}$ & $\begin{array}{c}\text { BSECEC } \\
(\%)\end{array}$ \\
\hline Oi & $0-2$ & $N / A$ & $\mathrm{~N} / \mathrm{A}$ & $\mathrm{N} / \mathrm{A}$ & $\mathrm{N} / \mathrm{A}$ & $\mathrm{N} / \mathrm{A}$ & $\mathrm{N} / \mathrm{A}$ & $\mathrm{N} / \mathrm{A}$ \\
\hline $\mathrm{Oe}$ & $2-6$ & 5.7 & $\mathrm{~N} / \mathrm{A}$ & 6.5 & $\mathrm{~N} / \mathrm{A}$ & 112.1 & 113.7 & 100.0 \\
\hline $\mathrm{Oa}$ & $6-12$ & 2.2 & $\mathrm{~N} / \mathrm{A}$ & 5.2 & $\mathrm{~N} / \mathrm{A}$ & 67.8 & 107.0 & 44.2 \\
\hline EA & $12-17$ & $\operatorname{tr}$ & 0.7 & 0.1 & 68.7 & 3.5 & 9.2 & $\operatorname{tr}$ \\
\hline$E$ & $30-41$ & $\operatorname{tr}$ & 0.5 & 0.7 & 47.6 & 2.9 & 6.2 & $\operatorname{tr}$ \\
\hline $\mathrm{Bw}$ & $41-61$ & 1.6 & 0.4 & 4.1 & 43.6 & 6.7 & 12.7 & 4.9 \\
\hline $\mathrm{BCg}$ & $61-79$ & 1.3 & 0.4 & 1.6 & 43.6 & 3.8 & 7.6 & 6.2 \\
\hline C & $79-99$ & 2.6 & 0.4 & 1.3 & 40.4 & 3.2 & 7.5 & 15.4 \\
\hline $\mathrm{Cg}$ & $101-150+$ & 11.0 & 0.4 & 3.4 & 41.2 & 6.4 & 10.9 & 35.3 \\
\hline $5^{*}$ Base S & Iration via $\mathrm{C}$ & Imatior & CEC $^{* * *}$ Catio & Exchange & apacity & & & \\
\hline
\end{tabular}




\section{Table 26 continued}

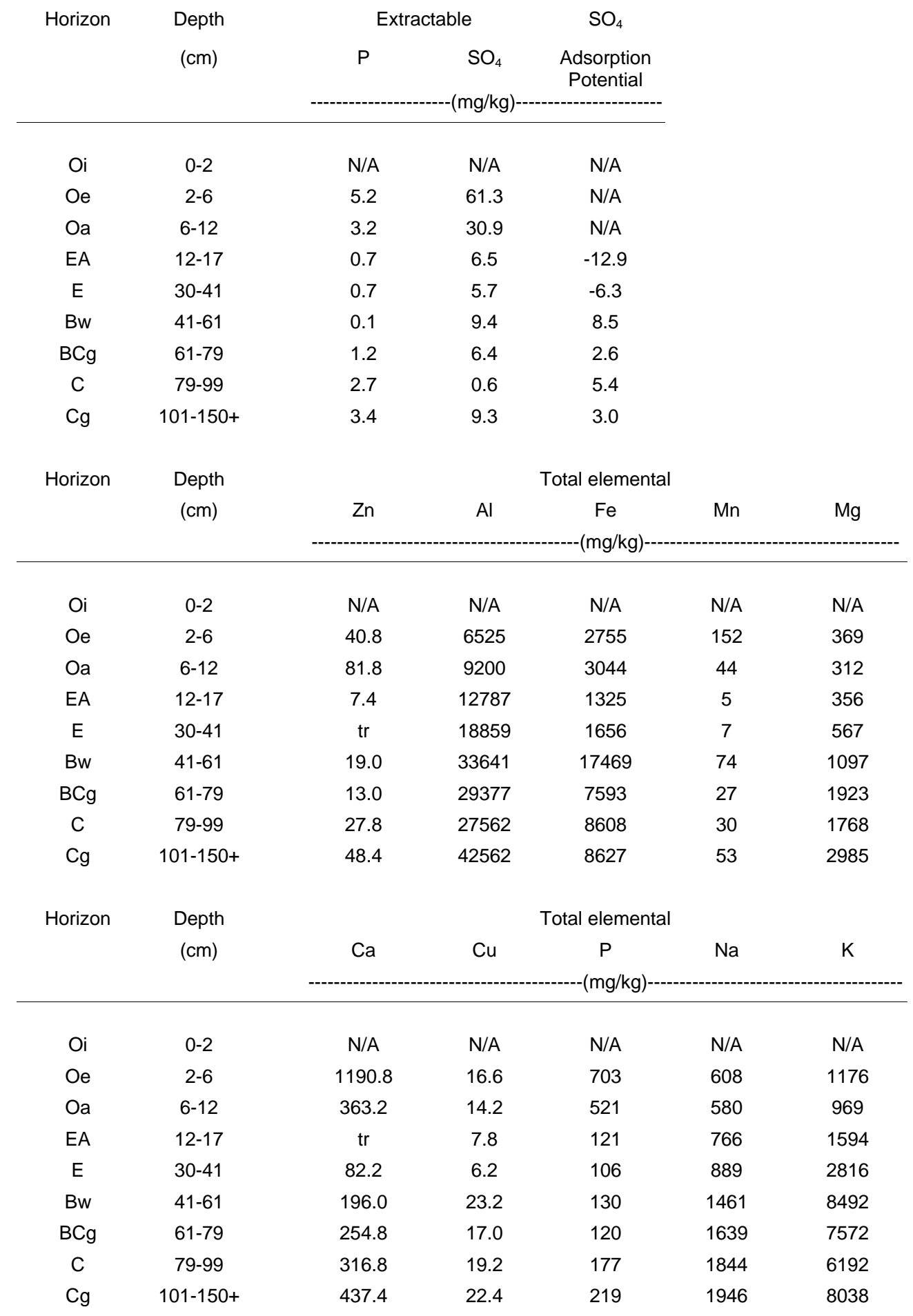




\section{Table 27. T3 Chemical Data}

\begin{tabular}{|c|c|c|c|c|c|c|c|}
\hline \multirow[t]{2}{*}{ Horizon } & \multirow{2}{*}{$\begin{array}{c}\text { Depth } \\
(\mathrm{cm})\end{array}$} & \multicolumn{2}{|c|}{$\mathrm{pH}$ (soil : solution) } & \multirow{2}{*}{$\begin{array}{c}\text { EC } \\
1: 2 \text { water } \\
\text { mmhos } \mathrm{cm}^{-1}\end{array}$} & \multirow[t]{2}{*}{ Total C } & \multirow[t]{2}{*}{ Total N } & \multirow[t]{2}{*}{ Total S } \\
\hline & & 1: 1 water & $1: 2 \mathrm{CaCl}_{2}$ & & & & \\
\hline Oi1 & $2-0$ & 4.1 & 3.6 & 0.67 & 48.1 & 1.0 & 0.1 \\
\hline Oi2 & $0-3$ & 3.7 & 2.9 & 0.23 & 45.6 & 1.4 & 0.2 \\
\hline $\mathrm{Oe}$ & $3-9$ & $3.4(5)^{\star}$ & $2.5(10)^{*}$ & $0.31(8)^{*}$ & 47.0 & 1.5 & 0.2 \\
\hline A & $9-18$ & 3.5 & 3.0 & 0.16 & 8.1 & 0.2 & $\operatorname{tr}$ \\
\hline $\mathrm{B} / \mathrm{A}$ & $18-28$ & 4.0 & 3.5 & 0.06 & 3.2 & 0.1 & $\operatorname{tr}$ \\
\hline Bw1 & $28-51$ & 4.3 & 3.8 & 0.06 & 3.2 & 0.1 & $\operatorname{tr}$ \\
\hline Bw2 & $51-93$ & 4.5 & 3.9 & 0.03 & 1.1 & $\operatorname{tr}$ & $\operatorname{tr}$ \\
\hline $\mathrm{BC}$ & $93-118$ & 4.5 & 3.9 & 0.07 & 0.9 & $\operatorname{tr}$ & $\operatorname{tr}$ \\
\hline $\mathrm{Cg}$ & $118-170+$ & 4.5 & 3.8 & 0.04 & 0.7 & $\operatorname{tr}$ & $\operatorname{tr}$ \\
\hline
\end{tabular}

*samples containing high OM content required higher dilutions than 1:1 or 1:2 (ex. 1 soil:4 water)

\begin{tabular}{|c|c|c|c|c|c|c|c|c|}
\hline \multirow[t]{3}{*}{ Horizon } & \multirow{3}{*}{$\begin{array}{l}\text { Depth } \\
(\mathrm{cm})\end{array}$} & \multicolumn{6}{|c|}{ Extractable } & \multirow{3}{*}{ Ca:Al } \\
\hline & & $\mathrm{Al}$ & Acidity & $\mathrm{Ca}$ & $\mathrm{Mg}$ & $\mathrm{Na}$ & $\mathrm{K}$ & \\
\hline & & \multicolumn{6}{|c|}{ - } & \\
\hline Oi1 & $2-0$ & $\mathrm{~N} / \mathrm{A}$ & $\mathrm{N} / \mathrm{A}$ & $\mathrm{N} / \mathrm{A}$ & $\mathrm{N} / \mathrm{A}$ & $\mathrm{N} / \mathrm{A}$ & $\mathrm{N} / \mathrm{A}$ & $\mathrm{N} / \mathrm{A}$ \\
\hline Oi2 & $0-3$ & $\mathrm{~N} / \mathrm{A}$ & $\mathrm{N} / \mathrm{A}$ & $\mathrm{N} / \mathrm{A}$ & $\mathrm{N} / \mathrm{A}$ & $\mathrm{N} / \mathrm{A}$ & $\mathrm{N} / \mathrm{A}$ & $\mathrm{N} / \mathrm{A}$ \\
\hline $\mathrm{Oe}$ & $3-9$ & $\operatorname{tr}$ & 115.1 & 2.3 & 1.5 & $\operatorname{tr}$ & 0.4 & 46.3 \\
\hline$A$ & $9-18$ & 15.3 & 49.6 & 0.1 & 0.2 & $\operatorname{tr}$ & 0.1 & 0.0 \\
\hline $\mathrm{B} / \mathrm{A}$ & $18-28$ & 14.3 & 40.8 & $\operatorname{tr}$ & 0.1 & $\operatorname{tr}$ & 0.1 & 0.0 \\
\hline Bw1 & $28-51$ & 11.7 & 40.6 & $\operatorname{tr}$ & $\operatorname{tr}$ & $\operatorname{tr}$ & 0.0 & 0.0 \\
\hline Bw2 & $51-93$ & 10.1 & 18.2 & $\operatorname{tr}$ & $\operatorname{tr}$ & $\operatorname{tr}$ & 0.1 & 0.0 \\
\hline$B C$ & $93-118$ & 8.6 & 27.6 & $\operatorname{tr}$ & $\operatorname{tr}$ & $\operatorname{tr}$ & 0.1 & 0.0 \\
\hline $\mathrm{Cg}$ & $118-170+$ & 9.9 & 20.7 & $\operatorname{tr}$ & $\operatorname{tr}$ & $\operatorname{tr}$ & 0.2 & 0.0 \\
\hline Horizon & $\begin{array}{l}\text { Depth } \\
(\mathrm{cm})\end{array}$ & $\begin{array}{l}\mathrm{BS}^{*} \\
(\%)\end{array}$ & $\begin{array}{c}\text { CEC Activity } \\
\text { Ratio }\end{array}$ & $\begin{array}{c}\mathrm{ECEC}^{* *} \\
\left(\mathrm{cmol}_{\mathrm{c}} / \mathrm{Kg}\right)\end{array}$ & $\begin{array}{l}\text { Apparent } \\
\text { CEC } \\
\left(\mathrm{cmol}_{\mathrm{c}} / \mathrm{Kg}\right. \\
\text { clay) }\end{array}$ & $\begin{array}{c}\mathrm{CEC}^{\star * *} \\
(\mathrm{NH} 4 \mathrm{OAc}) \\
-----\left(\mathrm{cmol}^{2}\right.\end{array}$ & $\begin{array}{c}\text { CEC }{ }^{* * *} \\
\text { (summation) } \\
\left.\mathrm{I}_{\mathrm{C}} / \mathrm{Kg}\right)^{----------}\end{array}$ & $\begin{array}{c}\text { BSECEC } \\
(\%)\end{array}$ \\
\hline Oi1 & $2-0$ & $N / A$ & $\mathrm{~N} / \mathrm{A}$ & $\mathrm{N} / \mathrm{A}$ & $\mathrm{N} / \mathrm{A}$ & $\mathrm{N} / \mathrm{A}$ & $\mathrm{N} / \mathrm{A}$ & $\mathrm{N} / \mathrm{A}$ \\
\hline Oi2 & $0-3$ & $N / A$ & $\mathrm{~N} / \mathrm{A}$ & $\mathrm{N} / \mathrm{A}$ & $\mathrm{N} / \mathrm{A}$ & $\mathrm{N} / \mathrm{A}$ & $\mathrm{N} / \mathrm{A}$ & $\mathrm{N} / \mathrm{A}$ \\
\hline $\mathrm{Oe}$ & $3-9$ & 3.5 & $\mathrm{~N} / \mathrm{A}$ & 4.2 & $\mathrm{~N} / \mathrm{A}$ & 92.8 & 119.3 & 100.0 \\
\hline$A$ & $9-18$ & 0.8 & 1.6 & 15.7 & 158.8 & 36.3 & 50.0 & 2.6 \\
\hline$B / A$ & $18-28$ & 0.5 & 1.0 & 14.5 & 103.9 & 28.0 & 41.0 & 1.4 \\
\hline Bw1 & $28-51$ & $\operatorname{tr}$ & 0.8 & 11.7 & 79.6 & 27.9 & 40.6 & $\operatorname{tr}$ \\
\hline Bw2 & $51-93$ & 0.6 & 0.5 & 10.2 & 48.5 & 16.9 & 18.3 & 1.0 \\
\hline$B C$ & $93-118$ & 0.4 & 0.4 & 8.7 & 40.9 & 14.9 & 27.7 & 1.2 \\
\hline $\mathrm{Cg}$ & $118-170+$ & 1.0 & 0.4 & 10.1 & 37.4 & 15.4 & 20.9 & 2.0 \\
\hline
\end{tabular}

BS $^{*}$ Base Saturation via CEC by summation $\mathrm{CEC}^{* * *}$ Cation Exchange Capacity ECEC $^{\star *}$ Effective Cation Exchange Capacity 


\section{Table 27 continued}

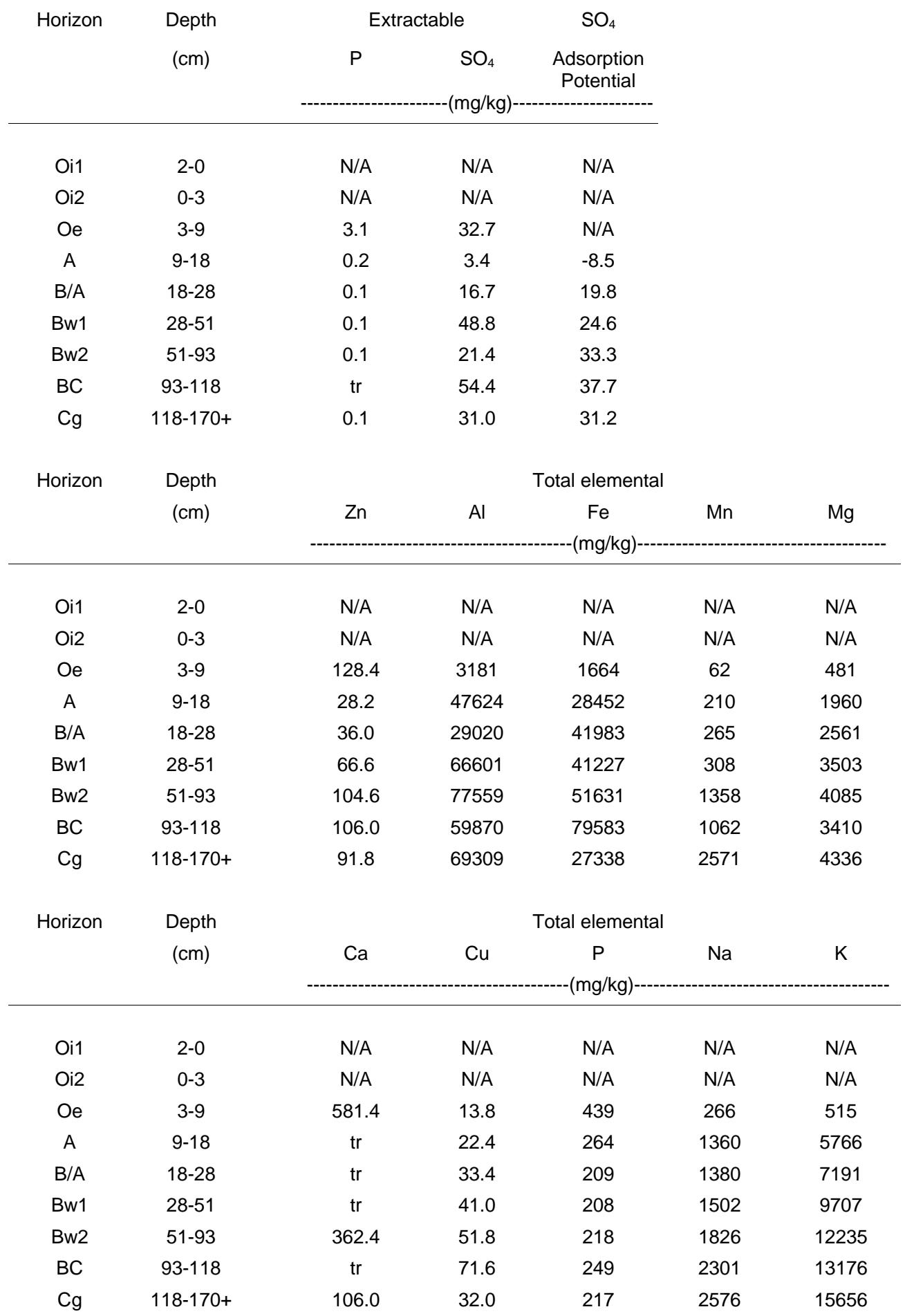




\section{Table 28. R1 Chemical Data}

\begin{tabular}{|c|c|c|c|c|c|c|c|}
\hline \multirow[t]{2}{*}{ Horizon } & \multirow{2}{*}{$\begin{array}{l}\text { Depth } \\
(\mathrm{cm})\end{array}$} & \multicolumn{2}{|c|}{$\mathrm{pH}$ (soil : solution) } & \multirow{2}{*}{$\begin{array}{c}\text { EC } \\
1: 2 \text { water } \\
\text { mmhos } \mathrm{cm}^{-1}\end{array}$} & \multirow[t]{2}{*}{ Total C } & \multirow[t]{2}{*}{ Total N } & \multirow[t]{2}{*}{ Total S } \\
\hline & & 1: 1 water & $1: 2 \mathrm{CaCl}_{2}$ & & & & \\
\hline Oi1 & $0-2$ & $4.0(6)^{*}$ & $3.5(12)^{*}$ & $0.42(8)^{*}$ & 34.2 & 1.1 & 0.1 \\
\hline Oa \& A & $2-3$ & $3.5(3)^{*}$ & $3.0(6)^{*}$ & 0.38 & 16.5 & 0.5 & 0.1 \\
\hline$A$ & $3-8$ & $3.3(2)^{*}$ & $3.1(4)^{\star}$ & 0.39 & 10.7 & 0.4 & 0.1 \\
\hline $\mathrm{BE}$ & $8-15$ & 3.5 & 3.3 & 0.13 & 5.5 & 0.1 & 0.1 \\
\hline Bw & $15-46$ & 4.0 & 3.5 & 0.05 & 4.4 & $\operatorname{tr}$ & 0.1 \\
\hline Bgx1 & $46-68$ & 4.6 & 3.7 & 0.03 & 5.4 & $\operatorname{tr}$ & 0.1 \\
\hline Bgx2 & $68-125$ & 4.9 & 4.0 & 0.03 & 5.5 & $\operatorname{tr}$ & 0.1 \\
\hline $\mathrm{C}$ & $125-150+$ & 4.6 & 3.9 & 0.02 & 0.4 & $\operatorname{tr}$ & $\operatorname{tr}$ \\
\hline
\end{tabular}

*samples containing high OM content required higher dilutions than 1:1 or 1:2 (ex. 1 soil:4 water)

\begin{tabular}{|c|c|c|c|c|c|c|c|c|}
\hline \multirow[t]{2}{*}{ Horizon } & \multirow{2}{*}{$\begin{array}{c}\text { Depth } \\
(\mathrm{cm})\end{array}$} & \multicolumn{6}{|c|}{ Extractable } & \multirow[b]{2}{*}{ Ca:Al } \\
\hline & & $\mathrm{Al}$ & Acidity & $\mathrm{Ca}$ & $\mathrm{Mg}$ & $\mathrm{Na}$ & $\mathrm{K}$ & \\
\hline Oi1 & $0-2$ & $\mathrm{~N} / \mathrm{A}$ & $\mathrm{N} / \mathrm{A}$ & $\mathrm{N} / \mathrm{A}$ & $\mathrm{N} / \mathrm{A}$ & $\mathrm{N} / \mathrm{A}$ & $\mathrm{N} / \mathrm{A}$ & $\mathrm{N} / \mathrm{A}$ \\
\hline Oa \& A & $2-3$ & 9.7 & 76.8 & 1.5 & 0.2 & $\operatorname{tr}$ & 0.1 & 0.2 \\
\hline$A$ & $3-8$ & 9.1 & 44.1 & 0.4 & 0.2 & $\operatorname{tr}$ & 0.2 & 0.0 \\
\hline BE & $8-15$ & 10.3 & 31.3 & 0.1 & 0.1 & $\operatorname{tr}$ & 0.1 & 0.0 \\
\hline $\mathrm{Bw}$ & $15-46$ & 4.3 & 18.2 & $\operatorname{tr}$ & $\operatorname{tr}$ & $\operatorname{tr}$ & $\operatorname{tr}$ & 0.0 \\
\hline $\mathrm{Bg} \times 1$ & $46-68$ & 2.8 & 12.7 & 0.3 & 0.3 & $\operatorname{tr}$ & 0.1 & 0.1 \\
\hline $\mathrm{Bg} 22$ & $68-125$ & 1.5 & 9.8 & 1.6 & 1.4 & $\operatorname{tr}$ & 0.1 & 1.1 \\
\hline C & $125-150+$ & 0.5 & 4.4 & 2.3 & 2.2 & $\operatorname{tr}$ & 0.1 & 4.6 \\
\hline \multirow[t]{2}{*}{ Horizon } & & & $\begin{array}{l}\text { CEC Activity } \\
\text { Ratio }\end{array}$ & ECEC $* *$ & Apparent CEC & $\begin{array}{l}\mathrm{CEC}^{* * *} \\
(\mathrm{NH} 4 \mathrm{OAc})\end{array}$ & $\begin{array}{c}\text { CEC }{ }^{* \star *} \\
\text { (summation) }\end{array}$ & BSECEC \\
\hline & $(\mathrm{cm})$ & $(\%)$ & & $\left(\mathrm{cmol}_{\mathrm{C}} / \mathrm{Kg}\right)$ & (cmol $/ \mathrm{Kg}$ clay) & \multicolumn{2}{|c|}{------(cmol $/ \mathrm{Kg})---$} & (\%) \\
\hline Oi1 & $0-2$ & $\mathrm{~N} / \mathrm{A}$ & $\mathrm{N} / \mathrm{A}$ & $\mathrm{N} / \mathrm{A}$ & $\mathrm{N} / \mathrm{A}$ & $\mathrm{N} / \mathrm{A}$ & $\mathrm{N} / \mathrm{A}$ & $\mathrm{N} / \mathrm{A}$ \\
\hline Oa \& A & $2-3$ & 2.3 & $N / A$ & 11.5 & $\mathrm{~N} / \mathrm{A}$ & 50.3 & 78.6 & 15.7 \\
\hline$A$ & $3-8$ & 1.8 & 5.5 & 9.9 & 551.1 & 116.2 & 44.9 & 8.1 \\
\hline $\mathrm{BE}$ & $8-15$ & 1.0 & 1.1 & 10.6 & 111.3 & 34.1 & 31.6 & 2.8 \\
\hline Bw & $15-46$ & $\operatorname{tr}$ & 0.7 & 4.3 & 66.4 & 16.5 & 18.2 & $\operatorname{tr}$ \\
\hline $\mathrm{Bgx} 1$ & $46-68$ & 5.2 & 0.8 & 3.4 & 76.4 & 12.2 & 13.4 & 20.0 \\
\hline $\mathrm{Bg} 22$ & $68-125$ & 24.0 & 0.6 & 4.6 & 56.0 & 10.9 & 12.9 & 67.4 \\
\hline C & $125-150+$ & 51.3 & 0.2 & 5.2 & 24.9 & 8.9 & 9.0 & 90.2 \\
\hline
\end{tabular}

BS $^{*}$ Base Saturation via CEC by summation $\mathrm{CEC}^{* * *}$ Cation Exchange Capacity

ECEC $^{* *}$ Effective Cation Exchange Capacity 


\section{Table 28 continued}

\begin{tabular}{|c|c|c|c|c|c|c|}
\hline \multirow[t]{2}{*}{ Horizon } & \multirow{2}{*}{$\begin{array}{l}\text { Depth } \\
(\mathrm{cm})\end{array}$} & \multicolumn{2}{|c|}{ Extractable } & \multirow{2}{*}{$\begin{array}{c}\mathrm{SO}_{4} \\
\text { Adsorption } \\
\text { Potential }\end{array}$} & & \\
\hline & & $P$ & $\mathrm{SO}_{4}$ & & & \\
\hline Oi1 & $0-2$ & $\mathrm{~N} / \mathrm{A}$ & $\mathrm{N} / \mathrm{A}$ & $\mathrm{N} / \mathrm{A}$ & & \\
\hline Oa \& A & $2-3$ & 1.1 & 45.3 & $\mathrm{~N} / \mathrm{A}$ & & \\
\hline A & $3-8$ & 1.0 & 21.7 & -24.8 & & \\
\hline $\mathrm{BE}$ & $8-15$ & 0.2 & 15.4 & -1.5 & & \\
\hline $\mathrm{Bw}$ & $15-46$ & $\operatorname{tr}$ & 12.5 & 12.6 & & \\
\hline $\mathrm{Bg} \times 1$ & $46-68$ & 0.1 & 2.2 & 18.4 & & \\
\hline $\operatorname{Bg} 22$ & $68-125$ & 0.4 & 4.5 & 24.8 & & \\
\hline C & $125-150+$ & 0.1 & 1.8 & 25.8 & & \\
\hline \multirow[t]{2}{*}{ Horizon } & Depth & \multicolumn{4}{|c|}{ Total elemental } & \\
\hline & $(\mathrm{cm})$ & $\mathrm{Zn}$ & $\mathrm{Al}$ & $\mathrm{Fe}$ & $\mathrm{Mn}$ & $\mathrm{Mg}$ \\
\hline Oi1 & $0-2$ & $\mathrm{~N} / \mathrm{A}$ & $\mathrm{N} / \mathrm{A}$ & $\mathrm{N} / \mathrm{A}$ & $\mathrm{N} / \mathrm{A}$ & $\mathrm{N} / \mathrm{A}$ \\
\hline Oa \& A & $2-3$ & 58.8 & 51131 & 18283 & 45 & 1681 \\
\hline A & $3-8$ & 94.8 & 46404 & 13159 & 16 & 1489 \\
\hline $\mathrm{BE}$ & $8-15$ & 167.4 & 47164 & 17632 & 15 & 1501 \\
\hline Bw & $15-46$ & 72.2 & 57739 & 49958 & 56 & 1766 \\
\hline $\operatorname{Bg} x 1$ & $46-68$ & 88.6 & 64408 & 40031 & 168 & 2125 \\
\hline $\mathrm{Bg} 22$ & $68-125$ & 80.6 & 59370 & 19283 & 49 & 1987 \\
\hline C & $125-150+$ & 70.2 & 78512 & 11022 & 106 & 2291 \\
\hline \multirow[t]{2}{*}{ Horizon } & Depth & \multicolumn{5}{|c|}{ Total elemental } \\
\hline & $(\mathrm{cm})$ & $\mathrm{Ca}$ & $\mathrm{Cu}$ & $P$ & $\mathrm{Na}$ & $\mathrm{K}$ \\
\hline Oi1 & $0-2$ & $\mathrm{~N} / \mathrm{A}$ & $\mathrm{N} / \mathrm{A}$ & $\mathrm{N} / \mathrm{A}$ & $\mathrm{N} / \mathrm{A}$ & $\mathrm{N} / \mathrm{A}$ \\
\hline Oa \& A & $2-3$ & 336.2 & 28.8 & 713 & 994 & 7784 \\
\hline A & $3-8$ & 346.6 & 20.2 & 596 & 1341 & 7953 \\
\hline $\mathrm{BE}$ & $8-15$ & 300.6 & 40.2 & 578 & 1488 & 9083 \\
\hline Bw & $15-46$ & 280.0 & 81.2 & 304 & 1343 & 9507 \\
\hline $\mathrm{Bgx} 1$ & $46-68$ & 349.6 & 73.6 & 258 & 1664 & 14140 \\
\hline Bgx2 & $68-125$ & 617.8 & 51.2 & 312 & 1977 & 14740 \\
\hline $\mathrm{C}$ & $125-150+$ & 410.2 & 25.2 & 158 & 2159 & 20560 \\
\hline
\end{tabular}


Table 29. R2 Chemical Data

\begin{tabular}{|c|c|c|c|c|c|c|c|}
\hline \multirow[t]{2}{*}{ Horizon } & \multirow{2}{*}{$\begin{array}{l}\text { Depth } \\
(\mathrm{cm})\end{array}$} & \multicolumn{2}{|c|}{$\mathrm{pH}$ (soil : solution) } & \multirow{2}{*}{$\begin{array}{c}\text { EC } \\
1: 2 \text { water } \\
\text { mmhos } \mathrm{cm}^{-1}\end{array}$} & \multirow[t]{2}{*}{ Total C } & \multirow[t]{2}{*}{ Total N } & \multirow[t]{2}{*}{ Total S } \\
\hline & & 1: 1 water & $1: 2 \mathrm{CaCl}_{2}$ & & & & \\
\hline Oi1 & $0-1$ & $4.8(4)^{*}$ & $4.3(8)^{*}$ & $0.69(10)^{*}$ & 48.5 & 1.6 & 0.2 \\
\hline Oi2 & $1-3$ & $4.2(4)^{*}$ & $3.5(8)^{*}$ & $0.45(8)^{*}$ & 43.5 & 1.6 & 0.2 \\
\hline$A$ & $3-10$ & 3.2 & 3.1 & 0.45 & 6.9 & 0.3 & 0.1 \\
\hline$A B$ & $10-16$ & 3.3 & 3.2 & 0.37 & 4.4 & 0.1 & $\operatorname{tr}$ \\
\hline Bw1 & $16-30$ & 4.2 & 3.7 & 0.05 & 1.1 & $\operatorname{tr}$ & $\operatorname{tr}$ \\
\hline Bw2 & $30-44$ & 4.4 & 3.7 & 0.04 & 0.8 & $\operatorname{tr}$ & $\operatorname{tr}$ \\
\hline Bw3 & $44-70$ & 4.5 & 3.8 & 0.06 & 0.6 & $\operatorname{tr}$ & $\operatorname{tr}$ \\
\hline $\mathrm{Bx}$ & $70-110$ & 4.7 & 3.7 & 0.02 & 0.5 & $\operatorname{tr}$ & $\operatorname{tr}$ \\
\hline $\mathrm{C}$ & $110-150+$ & 4.8 & 3.8 & 0.02 & 0.7 & $\operatorname{tr}$ & $\operatorname{tr}$ \\
\hline
\end{tabular}

*samples containing high OM content required higher dilutions than 1:1 or 1:2 (ex. 1 soil:4 water)

\begin{tabular}{|c|c|c|c|c|c|c|c|c|}
\hline \multirow[t]{2}{*}{ Horizon } & \multirow{2}{*}{$\begin{array}{l}\text { Depth } \\
(\mathrm{cm})\end{array}$} & \multicolumn{6}{|c|}{ Extractable } & \multirow[b]{2}{*}{ Ca:Al } \\
\hline & & $\mathrm{Al}$ & Acidity & $\mathrm{Ca}$ & $\mathrm{Mg}$ & $\mathrm{Na}$ & $\mathrm{K}$ & \\
\hline Oi1 & $0-1$ & $\mathrm{~N} / \mathrm{A}$ & $\mathrm{N} / \mathrm{A}$ & $\mathrm{N} / \mathrm{A}$ & $\mathrm{N} / \mathrm{A}$ & $\mathrm{N} / \mathrm{A}$ & $\mathrm{N} / \mathrm{A}$ & $\mathrm{N} / \mathrm{A}$ \\
\hline Oi2 & $1-3$ & $\mathrm{~N} / \mathrm{A}$ & N/A & $\mathrm{N} / \mathrm{A}$ & $\mathrm{N} / \mathrm{A}$ & $\mathrm{N} / \mathrm{A}$ & $\mathrm{N} / \mathrm{A}$ & $\mathrm{N} / \mathrm{A}$ \\
\hline A & $3-10$ & 8.2 & 36.1 & 0.4 & 0.2 & $\operatorname{tr}$ & 0.1 & 0.0 \\
\hline$A B$ & $10-16$ & 8.4 & 29.2 & 0.1 & 0.1 & $\operatorname{tr}$ & 0.1 & 0.0 \\
\hline Bw1 & $16-30$ & 3.5 & 16.2 & $\operatorname{tr}$ & $\operatorname{tr}$ & $\operatorname{tr}$ & $\operatorname{tr}$ & 0.0 \\
\hline Bw2 & $30-44$ & 2.6 & 14.0 & 0.1 & $\operatorname{tr}$ & $\operatorname{tr}$ & $\operatorname{tr}$ & 0.0 \\
\hline Bw3 & $44-70$ & 2.3 & 12.9 & 0.1 & 0.1 & $\operatorname{tr}$ & 0.1 & 0.0 \\
\hline$B x$ & $70-110$ & 1.6 & 11.6 & 0.3 & 0.2 & $\operatorname{tr}$ & 0.1 & 0.2 \\
\hline C & $110-150+$ & 1.6 & 11.3 & 0.6 & 0.6 & $\operatorname{tr}$ & 0.1 & 0.4 \\
\hline Horizon & $\begin{array}{l}\text { Depth } \\
(\mathrm{cm})\end{array}$ & $\begin{array}{l}\mathrm{BS}^{*} \\
(\%)\end{array}$ & $\begin{array}{c}\text { CEC Activity } \\
\text { Ratio }\end{array}$ & $\begin{array}{c}\text { ECEC }^{* *} \\
\left(\mathrm{cmol}_{\mathrm{C}} / \mathrm{Kg}\right)\end{array}$ & $\begin{array}{l}\text { Apparent CEC } \\
\text { (cmol } / \mathrm{Kg} \text { clay) }\end{array}$ & $\begin{array}{r}\mathrm{CEC}^{* * *} \\
(\mathrm{NH} 4 \mathrm{OAc}) \\
(\mathrm{cm}\end{array}$ & $\begin{array}{c}\text { CEC } \\
\text { (summation) } \\
\left.\mathrm{l}_{\mathrm{C}} / \mathrm{Kg}\right)\end{array}$ & $\begin{array}{c}\text { BSECEC } \\
(\%)\end{array}$ \\
\hline Oi1 & $0-1$ & $\mathrm{~N} / \mathrm{A}$ & $\mathrm{N} / \mathrm{A}$ & $N / A$ & $\mathrm{~N} / \mathrm{A}$ & $\mathrm{N} / \mathrm{A}$ & $\mathrm{N} / \mathrm{A}$ & $\mathrm{N} / \mathrm{A}$ \\
\hline Oi2 & $1-3$ & $\mathrm{~N} / \mathrm{A}$ & N/A & $\mathrm{N} / \mathrm{A}$ & $\mathrm{N} / \mathrm{A}$ & $\mathrm{N} / \mathrm{A}$ & $\mathrm{N} / \mathrm{A}$ & $\mathrm{N} / \mathrm{A}$ \\
\hline A & $3-10$ & 1.9 & 1.5 & 8.9 & 145.6 & 23.7 & 36.8 & 7.9 \\
\hline$A B$ & $10-16$ & 1.0 & 0.9 & 8.7 & 94.5 & 19.4 & 29.5 & 3.5 \\
\hline Bw1 & $16-30$ & $\operatorname{tr}$ & 0.4 & 3.5 & 44.4 & 9.5 & 16.2 & $\operatorname{tr}$ \\
\hline Bw2 & $30-44$ & 0.7 & 0.4 & 2.7 & 37.2 & 7.7 & 14.1 & 3.7 \\
\hline Bw3 & $44-70$ & 2.3 & 0.3 & 2.6 & 28.4 & 7.2 & 13.2 & 11.5 \\
\hline$B x$ & $70-110$ & 4.9 & 0.3 & 2.2 & 27.0 & 7.5 & 12.2 & 27.3 \\
\hline C & $110-150+$ & 10.3 & 0.3 & 2.9 & 26.0 & 7.5 & 12.6 & 44.8 \\
\hline
\end{tabular}

BS $^{*}$ Base Saturation via CEC by summation CEC*** Cation Exchange Capacity ECEC $^{\star *}$ Effective Cation Exchange Capacity 


\section{Table 29 continued}

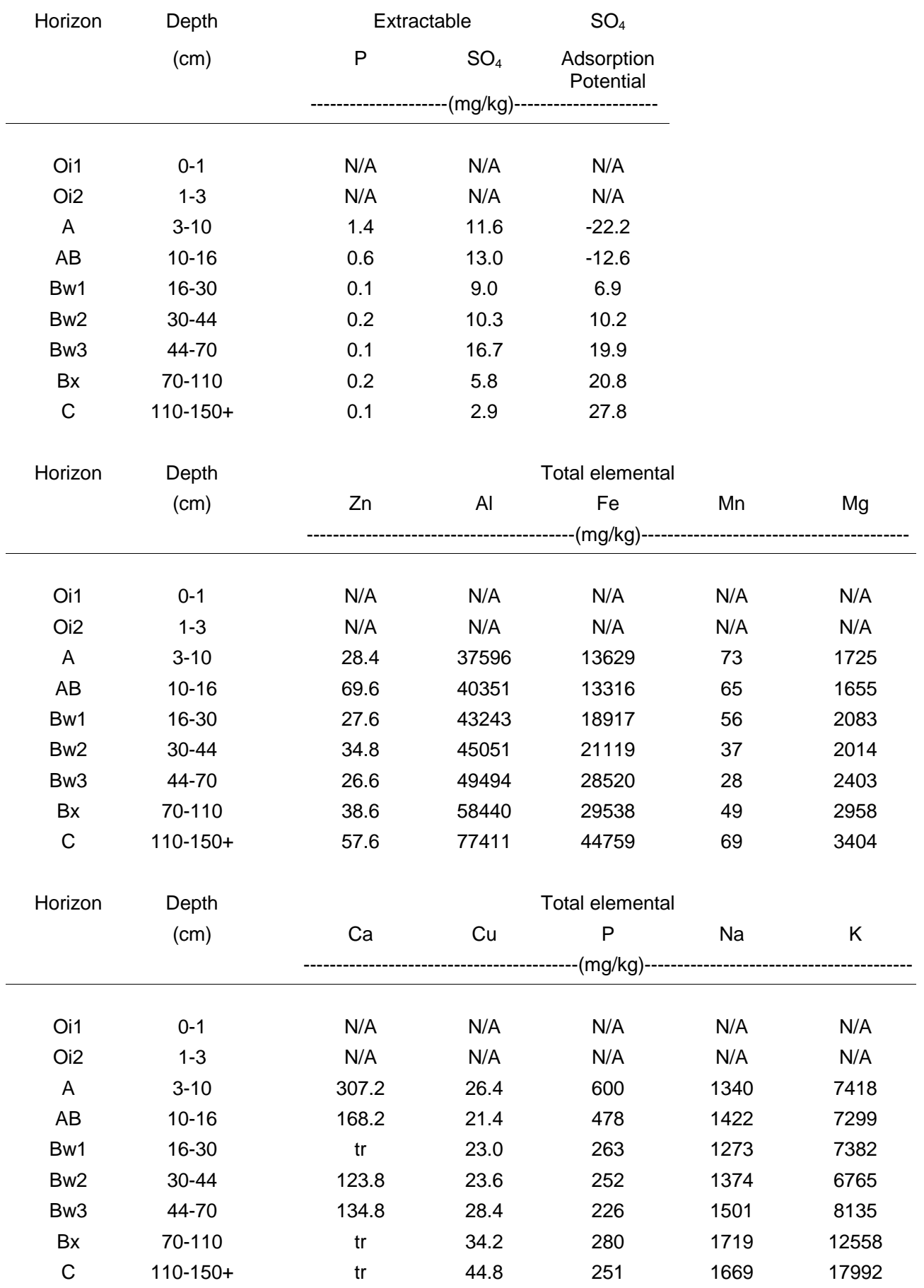


Table 30. R3 Chemical Data

\begin{tabular}{|c|c|c|c|c|c|c|c|}
\hline \multirow[t]{2}{*}{ Horizon } & \multirow{2}{*}{$\begin{array}{c}\text { Depth } \\
(\mathrm{cm})\end{array}$} & \multicolumn{2}{|c|}{ pH (soil : solution) } & \multirow{2}{*}{$\begin{array}{c}\text { EC } \\
1: 2 \text { water } \\
\text { mmhos } \mathrm{cm}^{-1}\end{array}$} & \multirow[t]{2}{*}{ Total C } & \multirow[t]{2}{*}{ Total N } & \multirow[t]{2}{*}{ Total S } \\
\hline & & 1: 1 water & $1: 2 \mathrm{CaCl}_{2}$ & & & & \\
\hline Oi1 & $0-1$ & $4.0(4)^{*}$ & $3.7(8)^{*}$ & $0.57(10)^{*}$ & 48.7 & 1.3 & 0.2 \\
\hline Oi2 & $1-4$ & $4.3(4)^{*}$ & $3.7(8)^{*}$ & $0.61(8)^{*}$ & 49.0 & 1.8 & 0.2 \\
\hline $\mathrm{Oe}$ & $4-7$ & $3.6(5)^{*}$ & $3.0(10)^{*}$ & $0.4(8)^{*}$ & 46.5 & 1.9 & 0.3 \\
\hline $\mathrm{Oa}$ & $7-42$ & $3.3(4)^{*}$ & $2.6(8)^{*}$ & $0.47(5)^{*}$ & 41.6 & 1.7 & 0.3 \\
\hline$E$ & $42-55$ & 3.6 & 3.1 & 0.09 & 0.6 & $\operatorname{tr}$ & $\operatorname{tr}$ \\
\hline $\mathrm{Bw}$ & $55-75$ & 3.9 & 3.4 & 0.05 & 1.1 & $\operatorname{tr}$ & $\operatorname{tr}$ \\
\hline $\mathrm{Bx}$ & $75-120$ & 4.2 & 3.6 & 0.06 & 0.9 & $\operatorname{tr}$ & $\operatorname{tr}$ \\
\hline $\mathrm{Cg}$ & $120-150+$ & 4.3 & 3.6 & 0.02 & 1.8 & $\operatorname{tr}$ & $\operatorname{tr}$ \\
\hline
\end{tabular}

*samples containing high OM content required higher dilutions than 1:1 or 1:2 (ex. 1 soil:4 water)

\begin{tabular}{|c|c|c|c|c|c|c|c|c|}
\hline \multirow[t]{3}{*}{ Horizon } & \multirow{3}{*}{$\begin{array}{c}\text { Depth } \\
(\mathrm{cm})\end{array}$} & \multicolumn{6}{|c|}{ Extractable } & \multirow{3}{*}{ Ca:Al } \\
\hline & & $\mathrm{Al}$ & Acidity & $\mathrm{Ca}$ & $\mathrm{Mg}$ & $\mathrm{Na}$ & $\mathrm{K}$ & \\
\hline & & \multicolumn{6}{|c|}{ - } & \\
\hline Oi1 & $0-1$ & $\mathrm{~N} / \mathrm{A}$ & $\mathrm{N} / \mathrm{A}$ & $\mathrm{N} / \mathrm{A}$ & $\mathrm{N} / \mathrm{A}$ & $\mathrm{N} / \mathrm{A}$ & $\mathrm{N} / \mathrm{A}$ & $\mathrm{N} / \mathrm{A}$ \\
\hline Oi2 & $1-4$ & $N / A$ & $\mathrm{~N} / \mathrm{A}$ & $\mathrm{N} / \mathrm{A}$ & $\mathrm{N} / \mathrm{A}$ & $\mathrm{N} / \mathrm{A}$ & $\mathrm{N} / \mathrm{A}$ & $\mathrm{N} / \mathrm{A}$ \\
\hline $\mathrm{Oe}$ & $4-7$ & $\operatorname{tr}$ & 108.7 & 6.2 & 1.2 & 0.1 & 0.7 & 123.4 \\
\hline $\mathrm{Oa}$ & $7-42$ & 2.0 & 109.2 & 1.5 & 0.6 & 0.1 & 0.4 & 0.7 \\
\hline$E$ & $42-55$ & 1.5 & 6.1 & 0.0 & $\operatorname{tr}$ & $\operatorname{tr}$ & $\operatorname{tr}$ & 0.0 \\
\hline $\mathrm{Bt}$ & $55-75$ & 4.1 & 11.5 & 0.1 & $\operatorname{tr}$ & $\operatorname{tr}$ & $\operatorname{tr}$ & 0.0 \\
\hline Btx & $75-120$ & 3.8 & 10.4 & $\operatorname{tr}$ & $\operatorname{tr}$ & $\operatorname{tr}$ & $\operatorname{tr}$ & 0.0 \\
\hline $\mathrm{Cg}$ & $120-150+$ & 4.7 & 13.2 & 0.1 & 0.1 & $\operatorname{tr}$ & 0.1 & 0.0 \\
\hline Horizon & $\begin{array}{l}\text { Depth } \\
(\mathrm{cm})\end{array}$ & $\begin{array}{l}\mathrm{BS}^{*} \\
(\%)\end{array}$ & $\begin{array}{c}\text { CEC Activity } \\
\text { Ratio }\end{array}$ & $\begin{array}{c}\text { ECEC }^{\star \star} \\
\left(\mathrm{cmol}_{\mathrm{c}} / \mathrm{Kg}\right)\end{array}$ & $\begin{array}{l}\text { Apparent CEC } \\
\text { (cmol } / \mathrm{Kg} \text { clay) }\end{array}$ & $\begin{array}{c}\mathrm{CEC}^{* * *} \\
(\mathrm{NH} 4 \mathrm{OAc})\end{array}$ & $\begin{array}{c}\mathrm{CEC}^{* * *} \\
\text { (summation) } \\
\mathrm{l}_{\mathrm{c}} / \mathrm{Kg} \text { )-------- }\end{array}$ & $\begin{array}{c}\text { BSECEC } \\
(\%)\end{array}$ \\
\hline Oi1 & $0-1$ & $N / A$ & $\mathrm{~N} / \mathrm{A}$ & $\mathrm{N} / \mathrm{A}$ & $\mathrm{N} / \mathrm{A}$ & $\mathrm{N} / \mathrm{A}$ & $\mathrm{N} / \mathrm{A}$ & $N / A$ \\
\hline Oi2 & $1-4$ & $N / A$ & $\mathrm{~N} / \mathrm{A}$ & $\mathrm{N} / \mathrm{A}$ & $\mathrm{N} / \mathrm{A}$ & $\mathrm{N} / \mathrm{A}$ & $\mathrm{N} / \mathrm{A}$ & $\mathrm{N} / \mathrm{A}$ \\
\hline Oe & $4-7$ & 7.0 & $\mathrm{~N} / \mathrm{A}$ & 8.2 & $\mathrm{~N} / \mathrm{A}$ & 137.6 & 116.9 & 100.0 \\
\hline $\mathrm{Oa}$ & $7-42$ & 2.3 & $\mathrm{~N} / \mathrm{A}$ & 4.6 & $\mathrm{~N} / \mathrm{A}$ & 98.3 & 111.8 & 56.5 \\
\hline$E$ & $42-55$ & $\operatorname{tr}$ & 0.4 & 1.5 & 43.8 & 3.6 & 6.1 & $\operatorname{tr}$ \\
\hline $\mathrm{Bt}$ & $55-75$ & 0.9 & 0.5 & 4.2 & 47.4 & 8.6 & 11.6 & 2.4 \\
\hline Btx & $75-120$ & $\operatorname{tr}$ & 0.3 & 3.8 & 34.7 & 7.7 & 10.4 & $\operatorname{tr}$ \\
\hline $\mathrm{Cg}$ & $120-150+$ & 2.3 & 0.3 & 5.0 & 34.9 & 11.4 & 13.3 & 6.0 \\
\hline
\end{tabular}




\section{Table 30 continued}

\begin{tabular}{|c|c|c|c|c|c|c|}
\hline \multirow[t]{2}{*}{ Horizon } & \multirow{2}{*}{$\begin{array}{l}\text { Depth } \\
(\mathrm{cm})\end{array}$} & \multicolumn{2}{|c|}{ Extractable } & \multirow{2}{*}{$\begin{array}{c}\mathrm{SO}_{4} \\
\text { Adsorption } \\
\text { Potential }\end{array}$} & & \\
\hline & & $P$ & $\mathrm{SO}_{4}$ & & & \\
\hline Oi1 & $0-1$ & $\mathrm{~N} / \mathrm{A}$ & $\mathrm{N} / \mathrm{A}$ & $\mathrm{N} / \mathrm{A}$ & & \\
\hline Oi2 & $1-4$ & $\mathrm{~N} / \mathrm{A}$ & $N / A$ & $\mathrm{~N} / \mathrm{A}$ & & \\
\hline Oe & $4-7$ & 8.5 & 84.0 & $\mathrm{~N} / \mathrm{A}$ & & \\
\hline $\mathrm{Oa}$ & $7-42$ & 5.9 & 55.7 & $\mathrm{~N} / \mathrm{A}$ & & \\
\hline$E$ & $42-55$ & 0.5 & 4.6 & -10.0 & & \\
\hline $\mathrm{Bt}$ & $55-75$ & 0.2 & 4.3 & -3.0 & & \\
\hline Btx & $75-120$ & 0.5 & 7.2 & 3.5 & & \\
\hline $\mathrm{Cg}$ & $120-150+$ & 0.1 & 5.0 & 7.6 & & \\
\hline \multirow[t]{2}{*}{ Horizon } & Depth & \multicolumn{5}{|c|}{ Total elemental } \\
\hline & $(\mathrm{cm})$ & $\mathrm{Zn}$ & $\mathrm{Al}$ & $\mathrm{Fe}$ & $\mathrm{Mn}$ & $\mathrm{Mg}$ \\
\hline Oi1 & $0-1$ & $\mathrm{~N} / \mathrm{A}$ & $\mathrm{N} / \mathrm{A}$ & $\mathrm{N} / \mathrm{A}$ & $\mathrm{N} / \mathrm{A}$ & $N / A$ \\
\hline Oi2 & $1-4$ & $\mathrm{~N} / \mathrm{A}$ & $N / A$ & $\mathrm{~N} / \mathrm{A}$ & $\mathrm{N} / \mathrm{A}$ & $\mathrm{N} / \mathrm{A}$ \\
\hline $\mathrm{Oe}$ & $4-7$ & 97.4 & 3638 & 1952 & 134 & 355 \\
\hline $\mathrm{Oa}$ & $7-42$ & 137.2 & 7870 & 4786 & 55 & 427 \\
\hline$E$ & $42-55$ & 91.8 & 18029 & 2111 & 5 & 464 \\
\hline $\mathrm{Bt}$ & $55-75$ & 89.8 & 45008 & 16121 & 6 & 1790 \\
\hline Btx & $75-120$ & 42.2 & 53850 & 16672 & 28 & 2355 \\
\hline $\mathrm{Cg}$ & $120-150+$ & 56.2 & 68400 & 16816 & 14 & 2732 \\
\hline \multirow[t]{2}{*}{ Horizon } & Depth & \multicolumn{5}{|c|}{ Total elemental } \\
\hline & $(\mathrm{cm})$ & $\mathrm{Ca}$ & $\mathrm{Cu}$ & $P$ & $\mathrm{Na}$ & $\mathrm{K}$ \\
\hline Oi1 & $0-1$ & $\mathrm{~N} / \mathrm{A}$ & $N / A$ & $\mathrm{~N} / \mathrm{A}$ & $\mathrm{N} / \mathrm{A}$ & $\mathrm{N} / \mathrm{A}$ \\
\hline Oi2 & $1-4$ & $\mathrm{~N} / \mathrm{A}$ & $N / A$ & $\mathrm{~N} / \mathrm{A}$ & $\mathrm{N} / \mathrm{A}$ & $N / A$ \\
\hline $\mathrm{Oe}$ & $4-7$ & 1332.6 & 12.8 & 790 & 330 & 598 \\
\hline $\mathrm{Oa}$ & $7-42$ & 332.2 & 19.8 & 733 & 632 & 1085 \\
\hline$E$ & $42-55$ & $\operatorname{tr}$ & $\operatorname{tr}$ & 127 & 697 & 2367 \\
\hline $\mathrm{Bt}$ & $55-75$ & $\operatorname{tr}$ & 21.6 & 235 & 1169 & 9860 \\
\hline Btx & $75-120$ & $\operatorname{tr}$ & 29.0 & 230 & 1464 & 13043 \\
\hline $\mathrm{Cg}$ & $120-150+$ & $\operatorname{tr}$ & 35.8 & 271 & 1854 & 20204 \\
\hline
\end{tabular}




\section{Table 31. R4 Chemical Data}

\begin{tabular}{|c|c|c|c|c|c|c|c|}
\hline \multirow[t]{2}{*}{ Horizon } & \multirow{2}{*}{$\begin{array}{l}\text { Depth } \\
(\mathrm{cm})\end{array}$} & \multicolumn{2}{|c|}{ pH (soil : solution) } & \multirow{2}{*}{$\begin{array}{c}\text { EC } \\
1: 2 \text { water } \\
\text { mmhos } \mathrm{cm}^{-1}\end{array}$} & \multirow[t]{2}{*}{ Total C } & \multirow[t]{2}{*}{ Total N } & \multirow[t]{2}{*}{ Total S } \\
\hline & & 1: 1 water & $1: 2 \mathrm{CaCl}_{2}$ & & & & \\
\hline Oi1 & $1-0$ & $3.8(6)^{*}$ & $3.3(12)^{*}$ & $0.41(10)^{*}$ & 48.3 & 1.0 & 0.2 \\
\hline Oi2 & $0-2$ & $4.0(4)^{*}$ & $3.4(8)^{*}$ & $0.56(8)^{*}$ & 49.3 & 1.4 & 0.2 \\
\hline $\mathrm{Oe}$ & $2-4$ & $N / A$ & $N / A$ & $\mathrm{~N} / \mathrm{A}$ & $\mathrm{N} / \mathrm{A}$ & $N / A$ & $\mathrm{~N} / \mathrm{A}$ \\
\hline $\mathrm{Oa} / \mathrm{A}$ & $4-12$ & 3.7 & 2.7 & 0.28 & 6.0 & 0.1 & $\operatorname{tr}$ \\
\hline $\mathrm{Eg}$ & $12-20$ & 3.6 & 3.1 & 0.09 & 0.8 & $\operatorname{tr}$ & $\operatorname{tr}$ \\
\hline $\mathrm{Bh}$ & $20-30$ & 3.6 & 3.1 & 0.05 & 1.7 & $\operatorname{tr}$ & $\operatorname{tr}$ \\
\hline Bw & $30-44$ & 4.1 & 3.6 & 0.12 & 1.0 & $\operatorname{tr}$ & $\operatorname{tr}$ \\
\hline $\mathrm{Bx}$ & $44-75$ & 4.4 & 3.8 & 0.03 & 0.3 & $\operatorname{tr}$ & $\operatorname{tr}$ \\
\hline $\mathrm{BCg}$ & $75-100$ & 4.6 & 3.8 & 0.03 & 0.3 & $\operatorname{tr}$ & $\operatorname{tr}$ \\
\hline $\mathrm{Cg}$ & $100-150+$ & 4.6 & 3.8 & 0.03 & 0.3 & $\operatorname{tr}$ & $\operatorname{tr}$ \\
\hline
\end{tabular}

*samples containing high OM content required higher dilutions than 1:1 or 1:2 (ex. 1 soil:4 water)

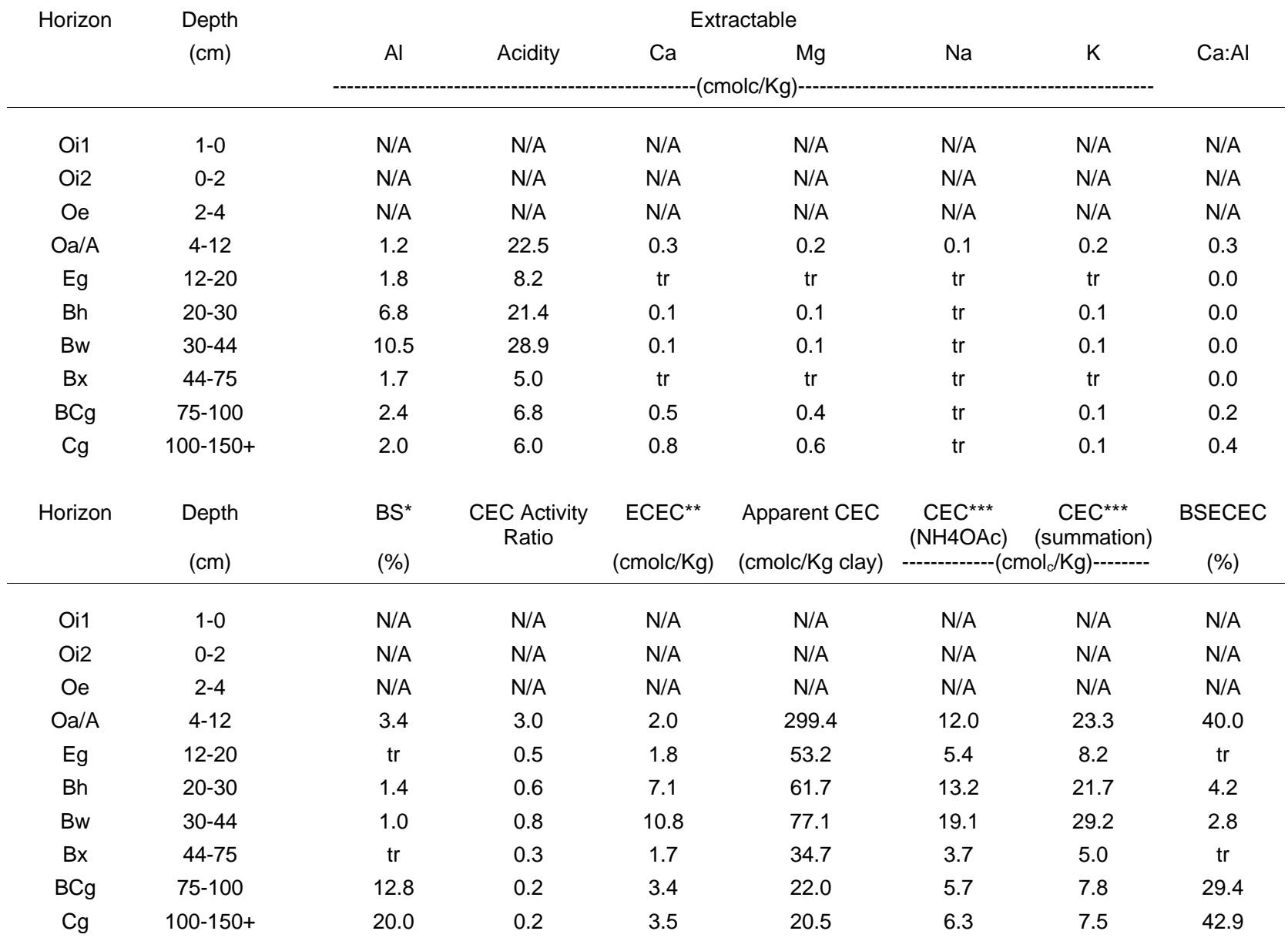

BS* $^{*}$ Base Saturation via CEC by summation $\mathrm{CEC}^{* * *}$ Cation Exchange Capacity ECEC $^{* *}$ Effective Cation Exchange Capacity 


\section{Table 31 continued}

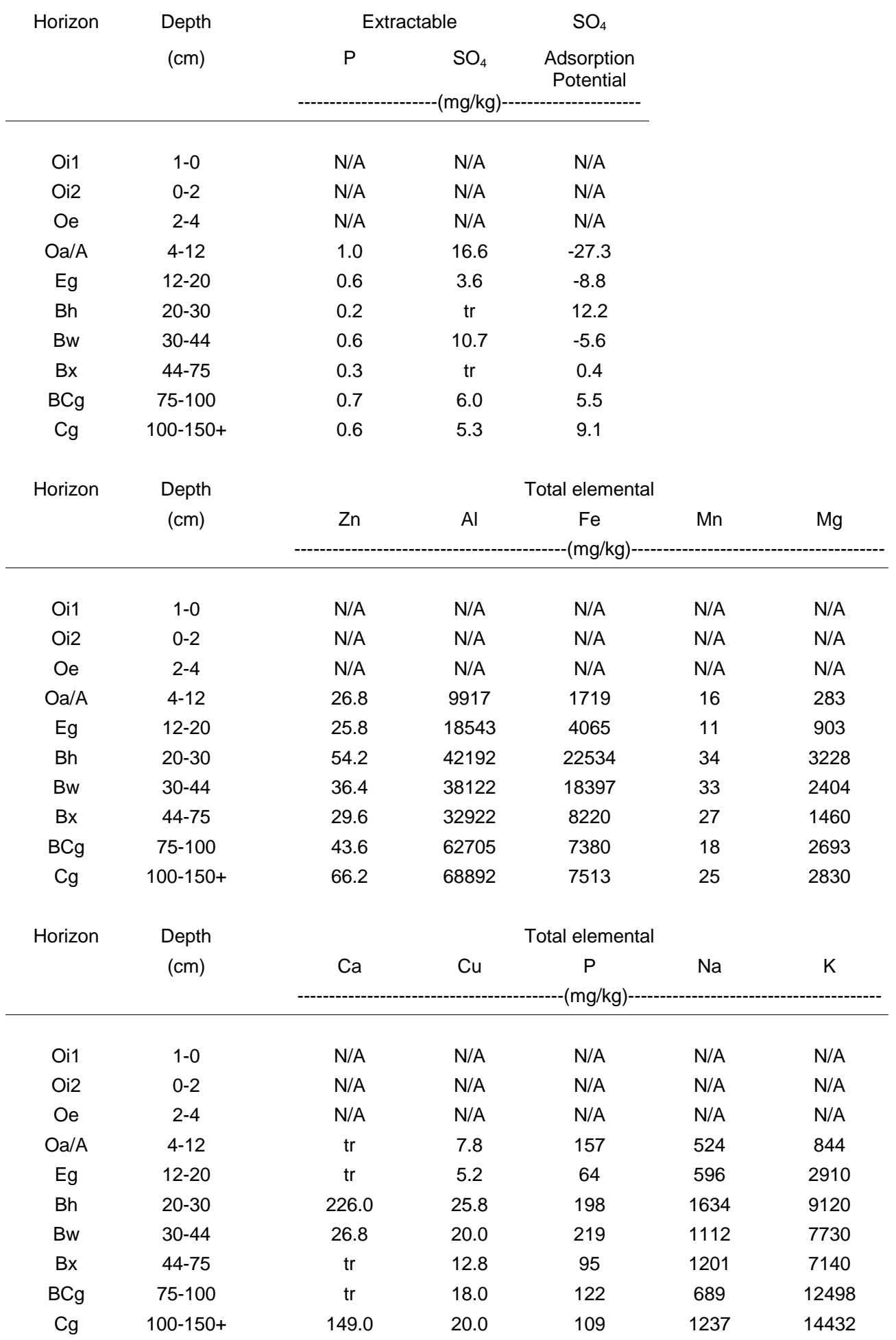


Table 32. SSC1 Chemical Data

\begin{tabular}{|c|c|c|c|c|c|c|c|}
\hline \multirow[t]{2}{*}{ Horizon } & \multirow{2}{*}{$\begin{array}{l}\text { Depth } \\
(\mathrm{cm})\end{array}$} & \multicolumn{2}{|c|}{$\mathrm{pH}$ (soil : solution) } & \multirow{2}{*}{$\begin{array}{c}\text { EC } \\
1: 2 \text { water } \\
\text { mmhos } \mathrm{cm}^{-1}\end{array}$} & \multirow[t]{2}{*}{ Total C } & \multirow[t]{2}{*}{ Total N } & \multirow[t]{2}{*}{ Total S } \\
\hline & & 1: 1 water & $1: 2 \mathrm{CaCl}_{2}$ & & & & \\
\hline Oi1 & $0-3$ & $3.5(8)^{*}$ & $3.3(16)^{\star}$ & $0.80(10)^{*}$ & 47.8 & 0.7 & 0.1 \\
\hline Oi2 & $3-6$ & $3.7(5)^{*}$ & $3.1(10)^{*}$ & $0.28(10)^{*}$ & 48.9 & 1.6 & 0.1 \\
\hline $\mathrm{Oe}$ & $6-8$ & $3.4(5)^{\star}$ & $2.8(10)^{*}$ & $0.28(8)^{*}$ & 47.9 & 1.9 & 0.2 \\
\hline $\mathrm{Oa} / \mathrm{A}$ & $8-15$ & $3.2(3)^{*}$ & $2.7(6)^{*}$ & $0.52(4)^{*}$ & 41.6 & 2.1 & 0.2 \\
\hline$A \circledast$ & $(15-76)$ & 3.3 & 3.0 & 0.43 & 7.0 & 0.2 & 0.1 \\
\hline$A / E$ & $15-30$ & 3.4 & 3.1 & 0.21 & 2.4 & 0.1 & $\operatorname{tr}$ \\
\hline $\mathrm{BE}$ & $30-58$ & 3.7 & 3.3 & 0.12 & 1.6 & $\operatorname{tr}$ & $\operatorname{tr}$ \\
\hline Bw & $58-89$ & 4.1 & 3.8 & 0.08 & 3.5 & 0.1 & $\operatorname{tr}$ \\
\hline Bs $\AA$ & $(76-89)$ & 4.0 & 3.6 & 0.02 & 2.5 & $\operatorname{tr}$ & $\operatorname{tr}$ \\
\hline $\mathrm{Bx}$ & $89-125$ & 4.6 & 4.4 & 0.07 & 1.5 & $\operatorname{tr}$ & $\operatorname{tr}$ \\
\hline Cx & $125-170_{+}$ & 4.6 & 4.3 & 0.02 & 1.1 & $\operatorname{tr}$ & $\operatorname{tr}$ \\
\hline
\end{tabular}

*samples containing high OM content required higher dilutions than 1:1 or $1: 2$ (ex. 1 soil:4 water)

(B) indicates that these horizons were only located on the right side of the pit and were not part of the pedon Horizon Depth Extractable

\begin{tabular}{|c|c|c|c|c|c|c|c|c|}
\hline & $(\mathrm{cm})$ & $\mathrm{Al}$ & Acidity & $\mathrm{Ca}$ & $\mathrm{Mg}$ & $\mathrm{Na}$ & $\mathrm{K}$ & Ca:Al \\
\hline Oi1 & $0-3$ & $N / A$ & $\mathrm{~N} / \mathrm{A}$ & $\mathrm{N} / \mathrm{A}$ & $\mathrm{N} / \mathrm{A}$ & $\mathrm{N} / \mathrm{A}$ & $\mathrm{N} / \mathrm{A}$ & $\mathrm{N} / \mathrm{A}$ \\
\hline Oi2 & $3-6$ & $N / A$ & $\mathrm{~N} / \mathrm{A}$ & $\mathrm{N} / \mathrm{A}$ & $\mathrm{N} / \mathrm{A}$ & $\mathrm{N} / \mathrm{A}$ & $\mathrm{N} / \mathrm{A}$ & $N / A$ \\
\hline $\mathrm{Oe}$ & $6-8$ & $\operatorname{tr}$ & 110.6 & 11.0 & 1.1 & 0.1 & 0.6 & 219.5 \\
\hline $\mathrm{Oa} / \mathrm{A}$ & $8-15$ & 6.8 & 105.7 & 1.1 & 0.7 & 0.2 & 0.9 & 0.2 \\
\hline $\mathrm{A} \circledast$ & $(15-76)$ & 4.4 & 27.3 & 0.4 & 0.1 & 0.1 & 0.1 & 0.1 \\
\hline$A / E$ & $15-30$ & 6.5 & 21.9 & 0.1 & 0.1 & $\operatorname{tr}$ & $\operatorname{tr}$ & 0.0 \\
\hline BE & $30-58$ & 5.8 & 18.6 & 0.1 & $\operatorname{tr}$ & $\operatorname{tr}$ & $\operatorname{tr}$ & 0.0 \\
\hline $\mathrm{Bw}$ & $58-89$ & 7.9 & 38.8 & $\operatorname{tr}$ & $\operatorname{tr}$ & $\operatorname{tr}$ & $\operatorname{tr}$ & 0.0 \\
\hline Bs ${ }^{\circledR}$ & $(76-89)$ & 0.9 & 12.1 & $\operatorname{tr}$ & $\operatorname{tr}$ & $\operatorname{tr}$ & $\operatorname{tr}$ & 0.1 \\
\hline $\mathrm{Bx}$ & $89-125$ & 7.8 & 33.1 & 0.1 & $\operatorname{tr}$ & $\operatorname{tr}$ & $\operatorname{tr}$ & 0.0 \\
\hline$C x$ & $125-170+$ & 0.8 & 9.8 & $\operatorname{tr}$ & $\operatorname{tr}$ & $\operatorname{tr}$ & $\operatorname{tr}$ & 0.1 \\
\hline \multirow[t]{2}{*}{ Horizon } & & & $\begin{array}{c}\text { CEC Activity } \\
\text { Ratio }\end{array}$ & ECEC ${ }^{* *}$ & Apparent CEC & $\begin{array}{l}\text { CEC } \\
(\mathrm{NH} 4 \mathrm{OAc})\end{array}$ & $\begin{array}{c}\text { CEC }{ }^{* * *} \\
\text { (summation) }\end{array}$ & \\
\hline & $(\mathrm{cm})$ & $(\%)$ & & $\left(\mathrm{cmol}_{\mathrm{c}} / \mathrm{Kg}\right)$ & $\left(\mathrm{cmol}_{\mathrm{C}} / \mathrm{Kg}\right.$ clay $)$ & \multicolumn{2}{|c|}{ - $\left(\mathrm{cmol}_{\mathrm{c}} / \mathrm{Kg}\right)-$} & $(\%)$ \\
\hline Oi1 & $0-3$ & $\mathrm{~N} / \mathrm{A}$ & $\mathrm{N} / \mathrm{A}$ & $\mathrm{N} / \mathrm{A}$ & $\mathrm{N} / \mathrm{A}$ & $\mathrm{N} / \mathrm{A}$ & $\mathrm{N} / \mathrm{A}$ & $\mathrm{N} / \mathrm{A}$ \\
\hline Oi2 & $3-6$ & $N / A$ & $\mathrm{~N} / \mathrm{A}$ & $\mathrm{N} / \mathrm{A}$ & $\mathrm{N} / \mathrm{A}$ & $\mathrm{N} / \mathrm{A}$ & $\mathrm{N} / \mathrm{A}$ & $\mathrm{N} / \mathrm{A}$ \\
\hline $\mathrm{Oe}$ & $6-8$ & 10.4 & $\mathrm{~N} / \mathrm{A}$ & 12.8 & $\mathrm{~N} / \mathrm{A}$ & 186.0 & 123.4 & 100.0 \\
\hline $\mathrm{Oa} / \mathrm{A}$ & $8-15$ & 2.7 & $\mathrm{~N} / \mathrm{A}$ & 9.7 & $\mathrm{~N} / \mathrm{A}$ & 95.8 & 108.6 & 29.9 \\
\hline$A \circledast$ & $(15-76)$ & 2.7 & 2.7 & 5.1 & 265.8 & 24.9 & 28.0 & 13.7 \\
\hline$A / E$ & $15-30$ & 2.5 & 1.3 & 6.7 & 128.2 & 15.6 & 22.1 & 3.0 \\
\hline $\mathrm{BE}$ & $30-58$ & 0.9 & 1.7 & 5.9 & 168.7 & 12.4 & 18.7 & 1.7 \\
\hline Bw & $58-89$ & $\operatorname{tr}$ & 2.3 & 7.9 & 233.3 & 23.1 & 38.8 & $\operatorname{tr}$ \\
\hline Bs $\AA$ & $(76-89)$ & $\operatorname{tr}$ & 5.2 & 0.9 & 516.5 & 6.9 & 12.1 & $\operatorname{tr}$ \\
\hline$B x$ & $89-125$ & 0.3 & 2.1 & 7.9 & 213.5 & 19.9 & 33.2 & 1.3 \\
\hline Cx & $125-170+$ & $\operatorname{tr}$ & 8.1 & 0.8 & 809.2 & 5.2 & 9.8 & $\operatorname{tr}$ \\
\hline
\end{tabular}

BS* $^{*}$ Base Saturation via CEC by summation ECEC** Effective Cation Exchange Capacity CEC ${ }^{* * *}$ Cation Exchange Capacity 


\section{Table 32 continued}

$\begin{array}{ccccc}\text { Horizon } & \begin{array}{c}\text { Depth } \\ (\mathrm{cm})\end{array} & \mathrm{c} & \mathrm{SO}_{4} & \begin{array}{c}\mathrm{SO}_{4} \\ \text { Adsorption } \\ \text { Potential }\end{array} \\ & & \mathrm{N} / \mathrm{A} & \mathrm{N} / \mathrm{A} & \mathrm{N} / \mathrm{A} \\ \text { Oi1 } & 0-3 & \mathrm{~N} / \mathrm{A} & \mathrm{N} / \mathrm{A} & \mathrm{N} / \mathrm{A} \\ \text { Oi2 } & 3-6 & 5.9 & 34.3 & \mathrm{~N} / \mathrm{A} \\ \mathrm{Oe} & 6-8 & 3.5 & 34.1 & \mathrm{~N} / \mathrm{A} \\ \mathrm{Oa} / \mathrm{A} & 8-15 & 0.9 & 14.3 & -25.5 \\ \mathrm{~A}{ }^{\circledR} & (15-76) & 0.2 & 4.8 & -8.6 \\ \mathrm{~A} / \mathrm{E} & 15-30 & 0.1 & 0.6 & -7.2 \\ \mathrm{BE} & 30-58 & 0.5 & 2.7 & 17.5 \\ \mathrm{Bw} & 58-89 & 0.8 & 1.3 & 5.8 \\ \mathrm{Bs}{ }^{\circledR} & (76-89) & 0.1 & 1.5 & 11.3 \\ \mathrm{Bx} & 89-125 & 1.3 & 1.5 & 4.0 \\ \mathrm{Cx} & 125-170+ & & \end{array}$

(B) indicates that these horizons were only located on the right side of the pit and were not part of the pedon

\begin{tabular}{|c|c|c|c|c|c|c|}
\hline \multirow[t]{2}{*}{ Horizon } & \multirow{2}{*}{$\begin{array}{c}\text { Depth } \\
(\mathrm{cm})\end{array}$} & \multicolumn{5}{|c|}{ Total elemental } \\
\hline & & $\mathrm{Zn}$ & $\mathrm{Al}$ & $\mathrm{Fe}$ & $\mathrm{Mn}$ & $\mathrm{Mg}$ \\
\hline Oi1 & $0-3$ & $\mathrm{~N} / \mathrm{A}$ & $\mathrm{N} / \mathrm{A}$ & $\mathrm{N} / \mathrm{A}$ & $\mathrm{N} / \mathrm{A}$ & $\mathrm{N} / \mathrm{A}$ \\
\hline Oi2 & $3-6$ & $\mathrm{~N} / \mathrm{A}$ & $\mathrm{N} / \mathrm{A}$ & $\mathrm{N} / \mathrm{A}$ & N/A & $\mathrm{N} / \mathrm{A}$ \\
\hline $\mathrm{Oe}$ & $6-8$ & 50.4 & 2457 & 1235 & 179 & 285 \\
\hline $\mathrm{Oa} / \mathrm{A}$ & $8-15$ & 92.2 & 9225 & 5150 & 59 & 354 \\
\hline $\mathrm{A} \circledast$ & $(15-76)$ & 37.8 & 28265 & 21096 & 35 & 822 \\
\hline$A / E$ & $15-30$ & 38.6 & 33181 & 26670 & 38 & 978 \\
\hline $\mathrm{BE}$ & $30-58$ & 34.8 & 39575 & 29834 & 37 & 1294 \\
\hline $\mathrm{Bw}$ & $58-89$ & 68.2 & 42434 & 31335 & 81 & 1689 \\
\hline Bs ${ }^{\circledR}$ & $(76-89)$ & 95.0 & 54692 & 35892 & 416 & 2425 \\
\hline $\mathrm{Bx}$ & $89-125$ & 58.0 & 48762 & 38852 & 51 & 1736 \\
\hline$C x$ & $125-170+$ & 78.8 & 49994 & 31089 & 428 & 1542 \\
\hline \multirow[t]{3}{*}{ Horizon } & Depth & \multicolumn{5}{|c|}{ Total elemental } \\
\hline & $(\mathrm{cm})$ & $\mathrm{Ca}$ & $\mathrm{Cu}$ & $P$ & $\mathrm{Na}$ & $\mathrm{K}$ \\
\hline & & 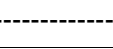 & ------ & $-(\mathrm{mg} / \mathrm{kg}$ & ------- & - \\
\hline Oi1 & $0-3$ & $\mathrm{~N} / \mathrm{A}$ & $\mathrm{N} / \mathrm{A}$ & $\mathrm{N} / \mathrm{A}$ & $\mathrm{N} / \mathrm{A}$ & $\mathrm{N} / \mathrm{A}$ \\
\hline Oi2 & $3-6$ & $\mathrm{~N} / \mathrm{A}$ & $\mathrm{N} / \mathrm{A}$ & $\mathrm{N} / \mathrm{A}$ & $\mathrm{N} / \mathrm{A}$ & $\mathrm{N} / \mathrm{A}$ \\
\hline $\mathrm{Oe}$ & $6-8$ & 2274.6 & 19.4 & 613 & 402 & 649 \\
\hline $\mathrm{Oa} / \mathrm{A}$ & $8-15$ & 635.8 & 29.2 & 394 & 878 & 1446 \\
\hline $\mathrm{A} \circledast$ & $(15-76)$ & $\operatorname{tr}$ & 25.8 & 249 & 1060 & 5305 \\
\hline$A / E$ & $15-30$ & $\operatorname{tr}$ & 30.0 & $\operatorname{tr}$ & 1007 & 4794 \\
\hline $\mathrm{BE}$ & $30-58$ & $\operatorname{tr}$ & 31.8 & 73 & 996 & 6412 \\
\hline $\mathrm{Bw}$ & $58-89$ & $\operatorname{tr}$ & 37.4 & 159 & 1232 & 7772 \\
\hline Bs $\AA$ & $(76-89)$ & 129.8 & 43.8 & 159 & 1520 & 10393 \\
\hline$B x$ & $89-125$ & 174.6 & 36.8 & $\operatorname{tr}$ & 1359 & 9229 \\
\hline$C x$ & $125-170+$ & 114.8 & 38.2 & $\operatorname{tr}$ & 1288 & 9513 \\
\hline
\end{tabular}


Table 33. SSC2 Chemical Data

\begin{tabular}{cccccccc} 
Horizon & $\begin{array}{c}\text { Depth } \\
(\mathrm{cm})\end{array}$ & $\begin{array}{c}\mathrm{pH} \text { (soil : solution) } \\
1: 1 \text { water }\end{array}$ & $\begin{array}{c}\mathrm{EC} \\
1: 2 \mathrm{CaCl}_{2}\end{array}$ & $\begin{array}{c}\text { Total C } \\
1: 2 \text { water } \\
\text { mmhos cm }\end{array}$ & Total N & Total S \\
\hline Oi1 & $0-2.5$ & $5.4(8)^{*}$ & $5.1(16)^{*}$ & $0.93(12)^{*}$ & 46.5 & 1.0 & 0.1 \\
A & $2.5-9$ & 4.0 & 3.6 & 0.15 & 3.7 & 0.2 & $\operatorname{tr}$ \\
BA & $9-30$ & 4.1 & 3.7 & 0.09 & 2.0 & $\operatorname{tr}$ & $\operatorname{tr}$ \\
Bt1 & $30-41$ & 4.3 & 3.8 & 0.06 & 1.3 & $\operatorname{tr}$ & $\operatorname{tr}$ \\
Bt2 & $41-61$ & 4.2 & 3.8 & 0.06 & 0.9 & $\operatorname{tr}$ & $\operatorname{tr}$ \\
BC & $61-79$ & 4.2 & 3.8 & 0.06 & 0.7 & $\operatorname{tr}$ & $\operatorname{tr}$ \\
C & $79-99$ & 4.1 & 3.7 & 0.09 & 0.8 & $\operatorname{tr}$ & $\operatorname{tr}$
\end{tabular}

*samples containing high OM content required higher dilutions than 1:1 or $1: 2$ (ex. 1 soil:4 water)

\begin{tabular}{|c|c|c|c|c|c|c|c|c|}
\hline \multirow[t]{2}{*}{ Horizon } & \multirow{2}{*}{$\begin{array}{l}\text { Depth } \\
(\mathrm{cm})\end{array}$} & \multicolumn{6}{|c|}{ Extractable } & \multirow[b]{2}{*}{ Ca:Al } \\
\hline & & $\mathrm{Al}$ & Acidity & $\mathrm{Ca}$ & $\mathrm{Mg}$ & $\mathrm{Na}$ & K & \\
\hline Oi1 & $0-2.5$ & $N / A$ & $\mathrm{~N} / \mathrm{A}$ & $\mathrm{N} / \mathrm{A}$ & $\mathrm{N} / \mathrm{A}$ & $N / A$ & $\mathrm{~N} / \mathrm{A}$ & $\mathrm{N} / \mathrm{A}$ \\
\hline A & $2.5-9$ & 10.0 & 28.0 & 0.4 & 0.2 & $\operatorname{tr}$ & 0.2 & 0.0 \\
\hline BA & $9-30$ & 8.6 & 23.5 & 0.1 & 0.1 & $\operatorname{tr}$ & 0.1 & 0.0 \\
\hline Bt1 & $30-41$ & 6.1 & 16.2 & 0.1 & $\operatorname{tr}$ & $\operatorname{tr}$ & 0.1 & 0.0 \\
\hline $\mathrm{Bt2}$ & $41-61$ & 5.8 & 14.8 & 0.1 & $\operatorname{tr}$ & $\operatorname{tr}$ & 0.1 & 0.0 \\
\hline$B C$ & $61-79$ & 6.2 & 13.5 & 0.1 & $\operatorname{tr}$ & $\operatorname{tr}$ & 0.1 & 0.0 \\
\hline C & $79-99$ & 7.1 & 17.5 & 0.1 & 0.1 & $\operatorname{tr}$ & 0.1 & 0.0 \\
\hline Horizon & $\begin{array}{l}\text { Depth } \\
(\mathrm{cm})\end{array}$ & $\begin{array}{l}\text { BS* } \\
(\%)\end{array}$ & $\begin{array}{l}\text { CEC Activity } \\
\text { Ratio }\end{array}$ & $\begin{array}{c}\mathrm{ECEC}^{* *} \\
\left(\mathrm{cmol}_{\mathrm{c}} / \mathrm{Kg}\right)\end{array}$ & $\begin{array}{l}\text { Apparent CEC } \\
\text { (cmol } / \mathrm{Kg} \text { clay) }\end{array}$ & $\begin{array}{c}\mathrm{CEC}^{\star * *} \\
(\mathrm{NH} 4 \mathrm{OAc})\end{array}$ & $\begin{array}{c}\mathrm{CEC}^{\star * *} \\
\text { (summation) } \\
\text { c/Kg)----------- }\end{array}$ & $\begin{array}{c}\text { BSECEC } \\
(\%)\end{array}$ \\
\hline Oi1 & $0-2.5$ & $N / A$ & $\mathrm{~N} / \mathrm{A}$ & $\mathrm{N} / \mathrm{A}$ & $\mathrm{N} / \mathrm{A}$ & $\mathrm{N} / \mathrm{A}$ & $\mathrm{N} / \mathrm{A}$ & $\mathrm{N} / \mathrm{A}$ \\
\hline$A$ & $2.5-9$ & 2.8 & 1.0 & 10.8 & 95.8 & 23.4 & 28.8 & 7.4 \\
\hline BA & $9-30$ & 1.3 & 0.6 & 8.9 & 65.0 & 17.9 & 23.8 & 3.4 \\
\hline $\mathrm{Bt} 1$ & $30-41$ & 1.2 & 0.6 & 6.3 & 59.7 & 12.2 & 16.4 & 3.2 \\
\hline $\mathrm{Bt} 2$ & $41-61$ & 1.3 & 0.6 & 6.0 & 63.9 & 11.9 & 15.0 & 3.3 \\
\hline $\mathrm{BC}$ & $61-79$ & 2.2 & 0.7 & 6.4 & 72.1 & 11.8 & 13.7 & 3.1 \\
\hline $\mathrm{C}$ & $79-99$ & 1.7 & 1.6 & 7.4 & 158.1 & 13.0 & 17.8 & 4.1 \\
\hline
\end{tabular}

BS* $^{*}$ Base Saturation via CEC by summation $\mathrm{CEC}^{* * *}$ Cation Exchange Capacity

ECEC $^{* *}$ Effective Cation Exchange Capacity 


\section{Table 33 continued}

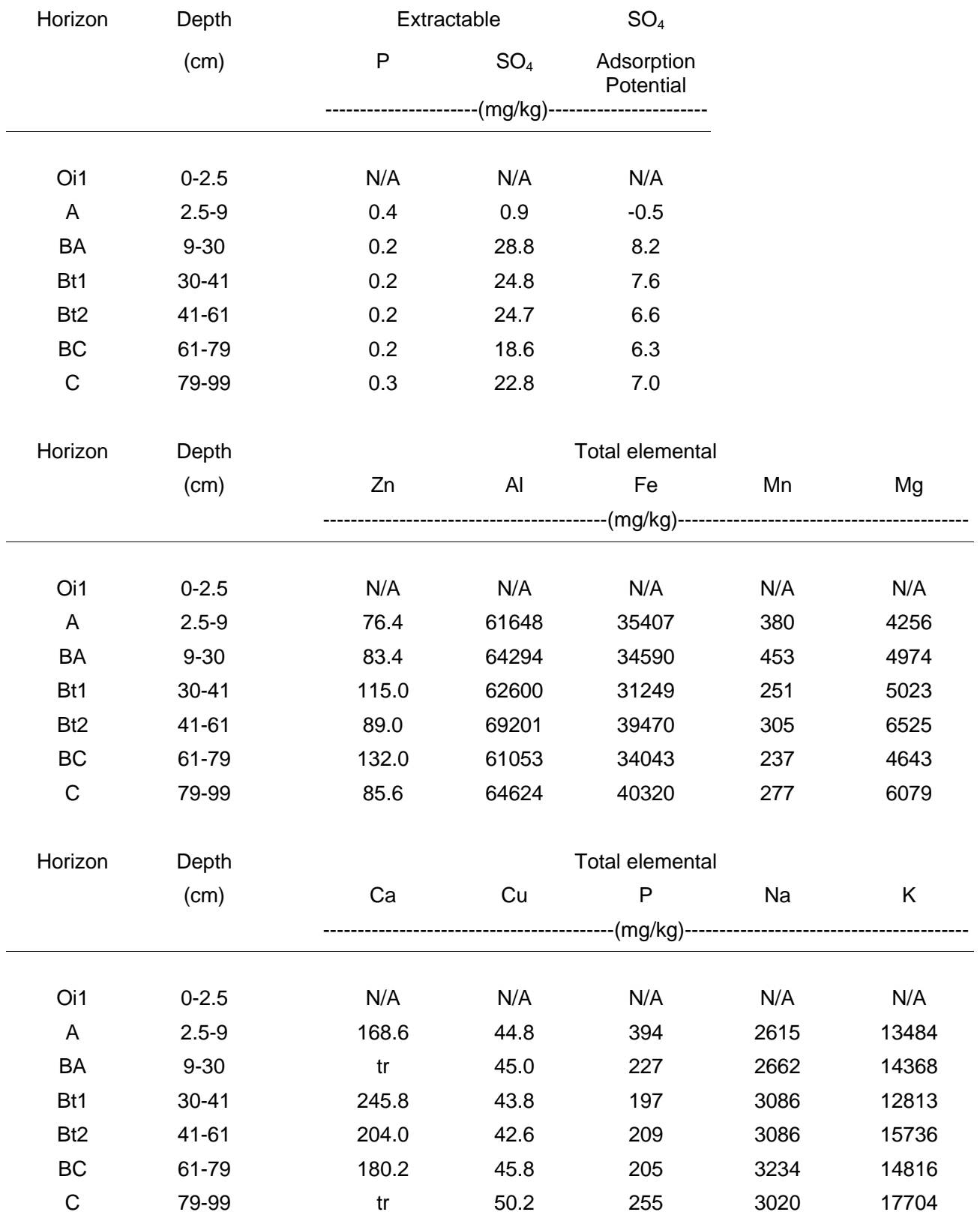




\section{Table 34. SSC3 Chemical Data}

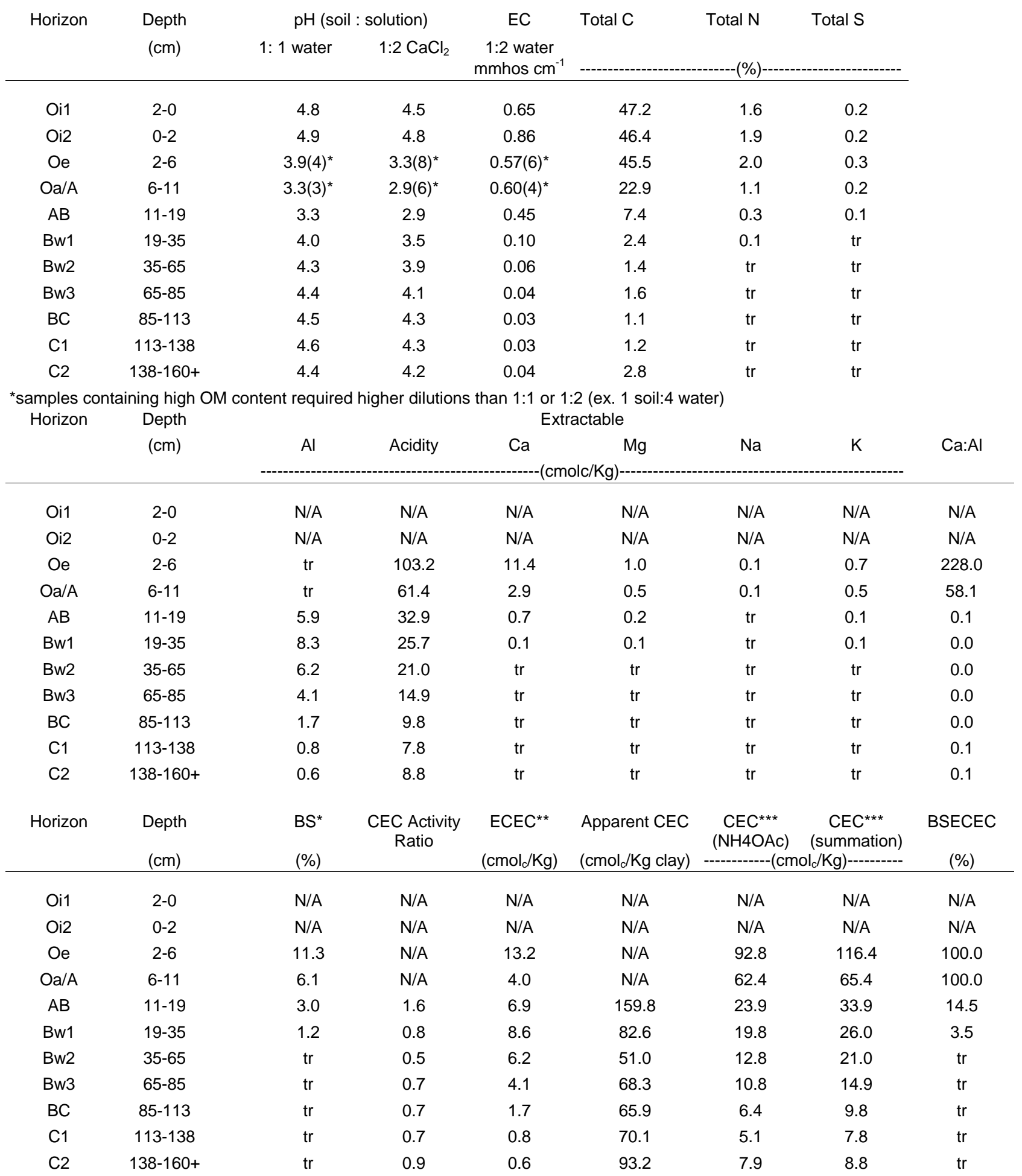

BS* $^{*}$ Base Saturation via CEC by summation CEC*** Cation Exchange Capacity

ECEC $^{* *}$ Effective Cation Exchange Capacity 


\section{Table 34 continued}

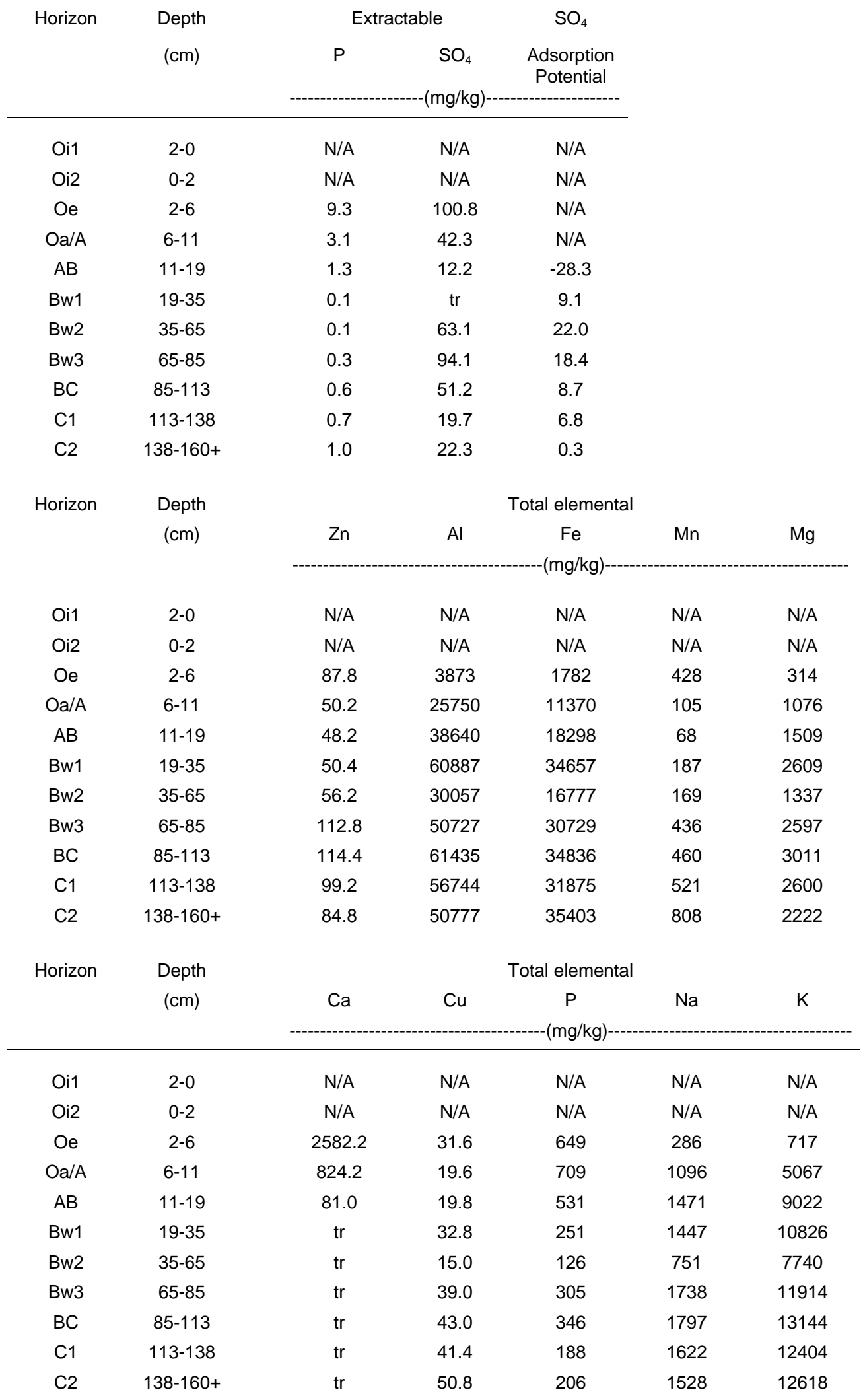


Table 35. SSA1 Chemical Data

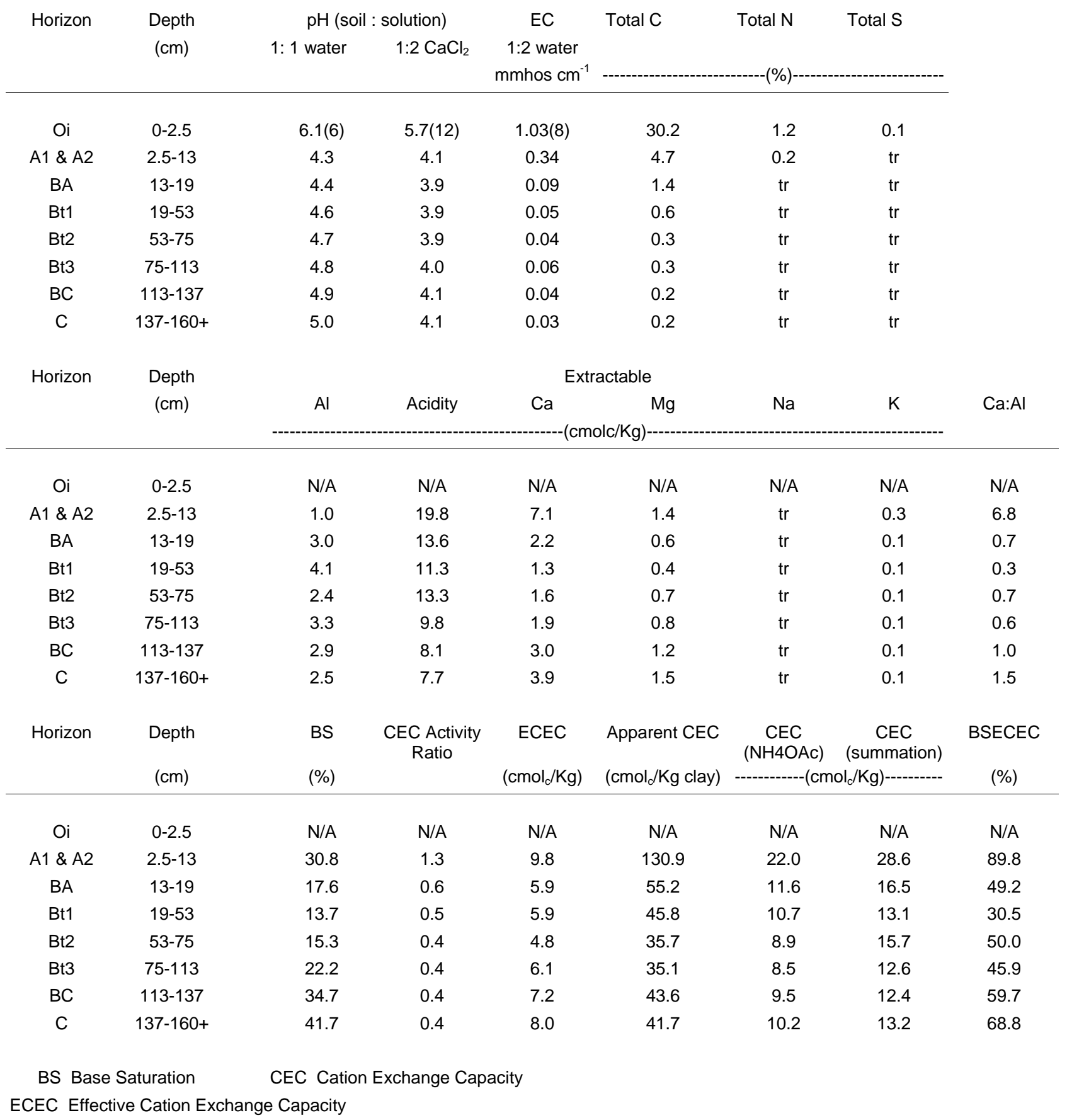




\section{Table 35 continued}

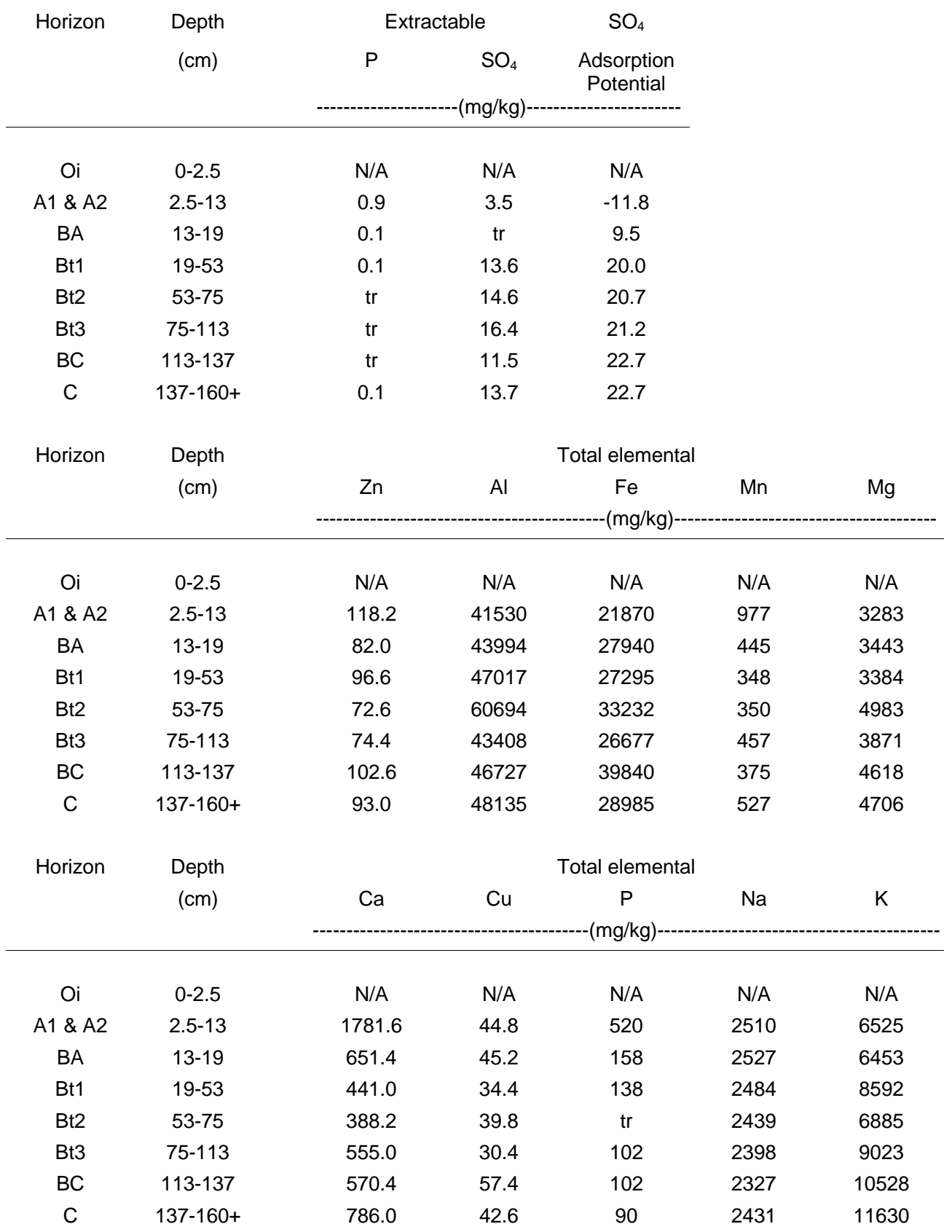




\section{Table 36. SSA2 Chemical Data}

\begin{tabular}{|c|c|c|c|c|c|c|c|c|}
\hline \multirow[t]{2}{*}{ Horizon } & \multirow{2}{*}{$\begin{array}{l}\text { Depth } \\
(\mathrm{cm})\end{array}$} & \multicolumn{2}{|c|}{ pH (soil : solution) } & \multirow{2}{*}{$\begin{array}{c}\text { EC } \\
1: 2 \text { water } \\
\text { mmhos } \mathrm{cm}^{-1}\end{array}$} & \multirow[t]{2}{*}{ Total C } & \multirow[t]{2}{*}{ Total N } & \multirow[t]{2}{*}{ Total S } & \\
\hline & & 1: 1 water & $1: 2 \mathrm{CaCl}_{2}$ & & & & & \\
\hline Oi1 & $0-1$ & $6.0(8)^{*}$ & $5.6(16)^{*}$ & $1.18(12)^{*}$ & 46.4 & 0.8 & 0.1 & \\
\hline Oi2 & $1-3$ & $5.6(6)^{*}$ & $5.1(12)^{*}$ & $0.72(10)^{*}$ & 42.4 & 1.3 & 0.1 & \\
\hline$A$ & $3-14$ & 3.7 & 3.6 & 0.48 & 4.8 & 0.2 & $\operatorname{tr}$ & \\
\hline BA & $14-34$ & 4.2 & 4.0 & 0.10 & 1.4 & $\operatorname{tr}$ & $\operatorname{tr}$ & \\
\hline $\mathrm{Bt} 1$ & $34-60$ & 4.4 & 3.8 & 0.05 & 0.4 & $\operatorname{tr}$ & $\operatorname{tr}$ & \\
\hline $\mathrm{Bt2}$ & $60-107$ & 4.5 & 3.8 & 0.04 & 0.3 & $\operatorname{tr}$ & $\operatorname{tr}$ & \\
\hline $\mathrm{BC}$ & $107-138$ & 4.6 & 3.7 & 0.04 & 0.2 & $\operatorname{tr}$ & $\operatorname{tr}$ & \\
\hline $\mathrm{C}$ & $138-152$ & 4.6 & 3.7 & 0.04 & 0.2 & $\operatorname{tr}$ & $\operatorname{tr}$ & \\
\hline \multicolumn{9}{|c|}{ *samples containing high OM content required higher dilutions than 1:1 or $1: 2$ (ex. 1 soil:4 water) } \\
\hline \multirow[t]{3}{*}{ Horizon } & Depth & \multicolumn{6}{|c|}{ Extractable } & \\
\hline & $(\mathrm{cm})$ & Al & Acidity & $\mathrm{Ca}$ & $\mathrm{Mg}$ & $\mathrm{Na}$ & $\mathrm{K}$ & Ca:Al \\
\hline & \multicolumn{7}{|c|}{ - } & \\
\hline Oi1 & $0-1$ & N/A & $\mathrm{N} / \mathrm{A}$ & $\mathrm{N} / \mathrm{A}$ & $\mathrm{N} / \mathrm{A}$ & $\mathrm{N} / \mathrm{A}$ & $\mathrm{N} / \mathrm{A}$ & $\mathrm{N} / \mathrm{A}$ \\
\hline Oi2 & $1-3$ & $\mathrm{~N} / \mathrm{A}$ & $\mathrm{N} / \mathrm{A}$ & $\mathrm{N} / \mathrm{A}$ & $\mathrm{N} / \mathrm{A}$ & $\mathrm{N} / \mathrm{A}$ & $\mathrm{N} / \mathrm{A}$ & $\mathrm{N} / \mathrm{A}$ \\
\hline A & $3-14$ & 4.4 & 22.9 & 1.1 & 0.3 & $\operatorname{tr}$ & 0.2 & 0.2 \\
\hline BA & $14-34$ & 3.4 & 12.4 & 0.2 & 0.1 & $\operatorname{tr}$ & 0.1 & 0.1 \\
\hline Bt1 & $34-60$ & 4.2 & 11.2 & 0.2 & 0.1 & $\operatorname{tr}$ & 0.1 & 0.1 \\
\hline $\mathrm{Bt} 2$ & $60-107$ & 5.1 & 11.1 & 0.5 & 0.1 & $\operatorname{tr}$ & 0.1 & 0.1 \\
\hline $\mathrm{BC}$ & $107-138$ & 5.7 & 12.8 & 0.8 & 0.6 & $\operatorname{tr}$ & 0.1 & 0.1 \\
\hline C & $138-152$ & 4.8 & 11.4 & 1.0 & 1.2 & 0.1 & 0.1 & 0.2 \\
\hline \multirow[t]{2}{*}{ Horizon } & Depth & $\mathrm{BS}^{*}$ & $\begin{array}{l}\text { CEC Activity } \\
\text { Ratio }\end{array}$ & $\mathrm{ECEC}^{* *}$ & Apparent CEC & $\begin{array}{l}\mathrm{CEC}^{* * *} \\
(\mathrm{NH} 4 \mathrm{OAc})\end{array}$ & $\begin{array}{c}\mathrm{CEC}^{* * *} \\
\text { (summation) }\end{array}$ & BSECEC \\
\hline & $(\mathrm{cm})$ & $(\%)$ & & $\left(\mathrm{cmol}_{\mathrm{c}} / \mathrm{Kg}\right)$ & (cmol $/ \mathrm{Kg}$ clay) & \multicolumn{2}{|c|}{ 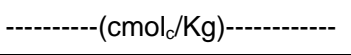 } & (\%) \\
\hline Oi1 & $0-1$ & $\mathrm{~N} / \mathrm{A}$ & $\mathrm{N} / \mathrm{A}$ & $N / A$ & $N / A$ & $\mathrm{~N} / \mathrm{A}$ & $\mathrm{N} / \mathrm{A}$ & $\mathrm{N} / \mathrm{A}$ \\
\hline Oi2 & $1-3$ & $\mathrm{~N} / \mathrm{A}$ & $\mathrm{N} / \mathrm{A}$ & $\mathrm{N} / \mathrm{A}$ & $\mathrm{N} / \mathrm{A}$ & $\mathrm{N} / \mathrm{A}$ & $\mathrm{N} / \mathrm{A}$ & $\mathrm{N} / \mathrm{A}$ \\
\hline$A$ & $3-14$ & 6.5 & 1.9 & 6.0 & 189.9 & 25.8 & 24.5 & 26.7 \\
\hline BA & $14-34$ & 3.1 & 0.5 & 3.8 & 50.2 & 9.5 & 12.8 & 10.5 \\
\hline $\mathrm{Bt} 1$ & $34-60$ & 3.5 & 0.4 & 4.6 & 37.1 & 9.1 & 11.6 & 8.7 \\
\hline $\mathrm{Bt} 2$ & $60-107$ & 5.9 & 0.5 & 5.8 & 49.3 & 9.9 & 11.8 & 12.1 \\
\hline $\mathrm{BC}$ & $107-138$ & 10.5 & 0.6 & 7.2 & 55.3 & 11.3 & 14.3 & 20.8 \\
\hline C & $138-152$ & 17.4 & 0.7 & 7.2 & 67.2 & 11.3 & 13.8 & 33.3 \\
\hline \multicolumn{6}{|c|}{$\begin{array}{l}\mathrm{BS}^{*} \text { Base Saturation via CEC by summation } \\
\mathrm{ECEC}^{* *} \text { Effective Cation Exchange Capacity }\end{array}$} & & & \\
\hline
\end{tabular}




\section{Table 36 continued}

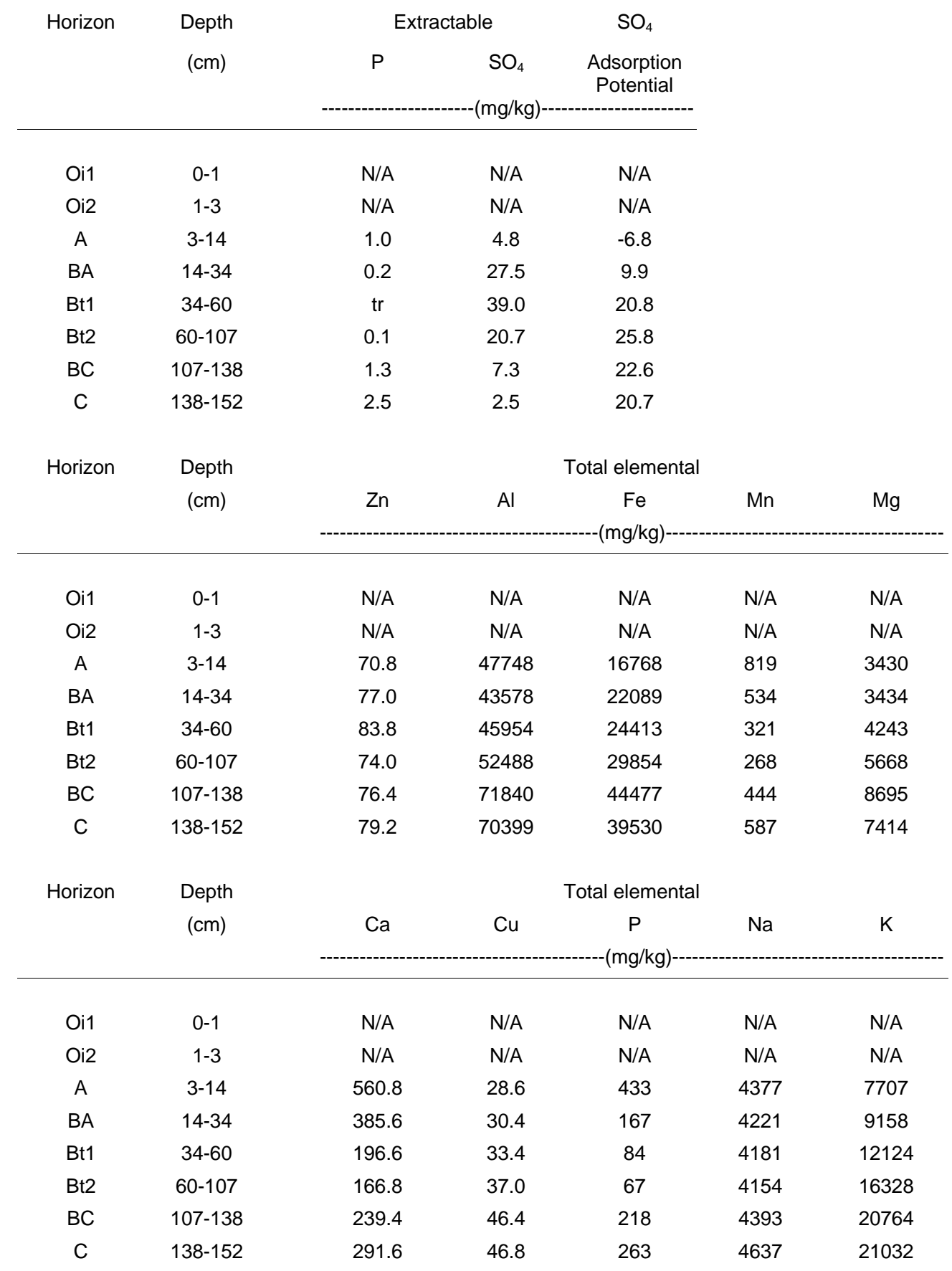




\section{Table 37. SSA3 Chemical Data}

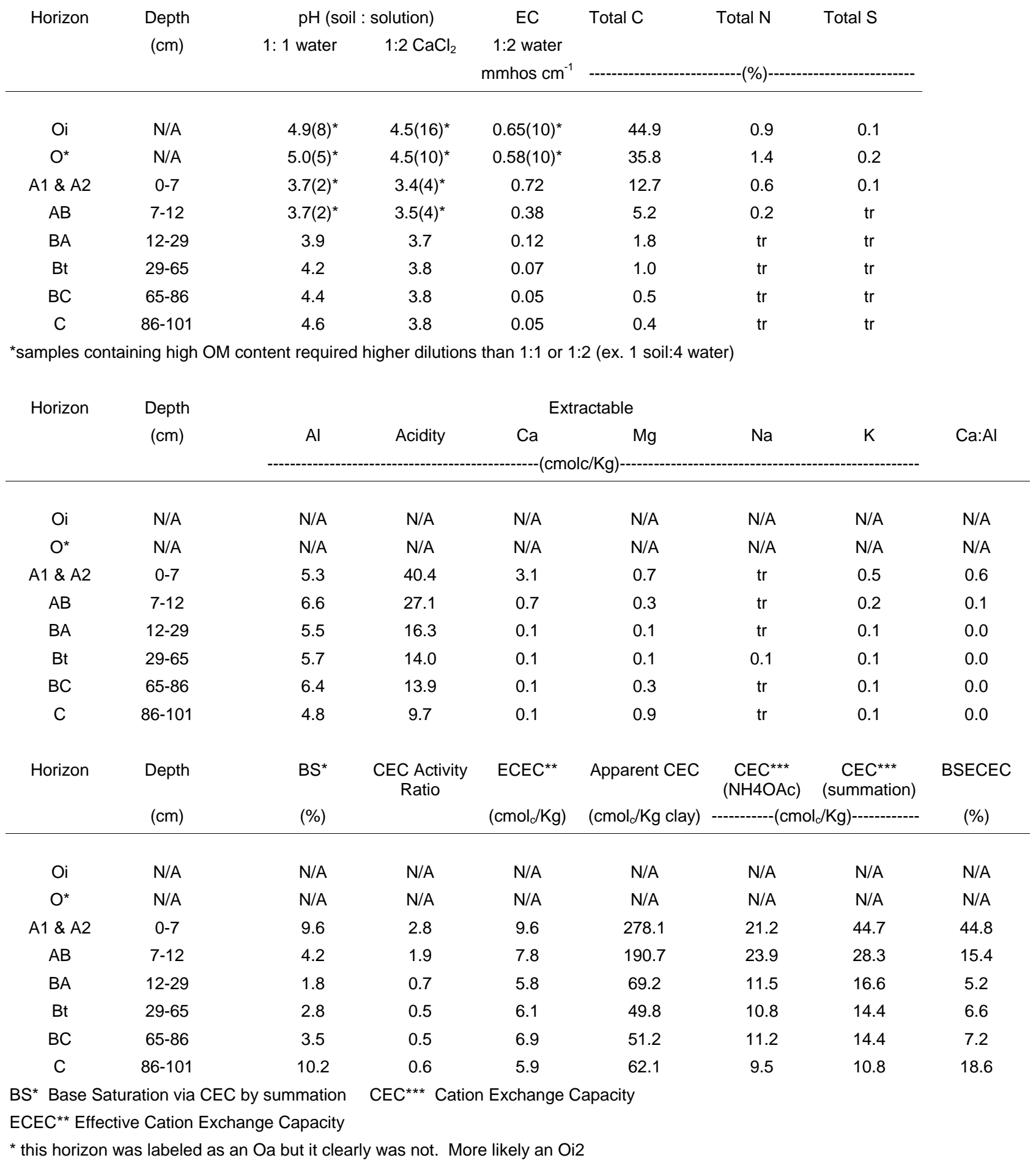




\section{Table 37 continued}

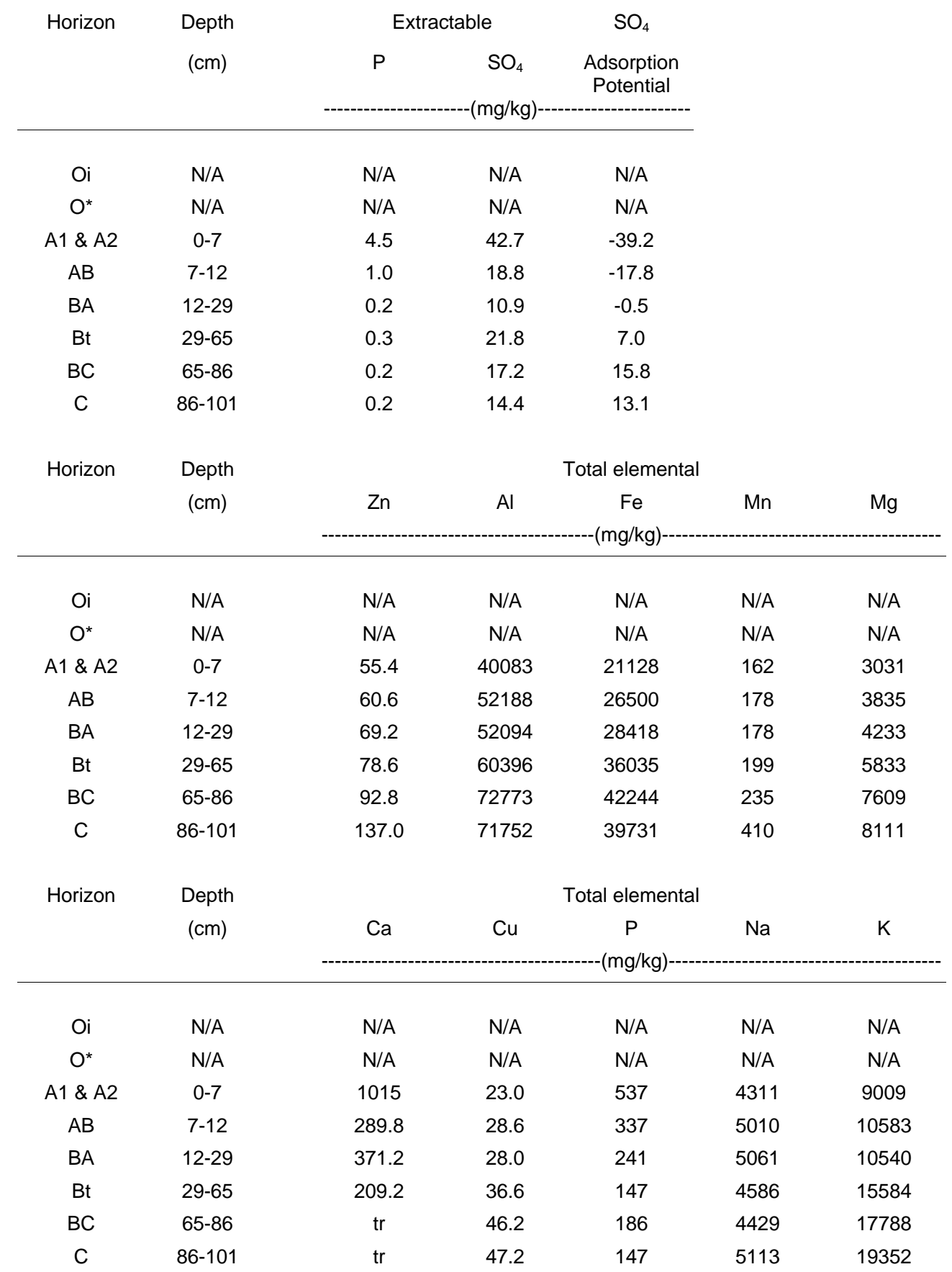

* this horizon was labeled as an Oa but it clearly was not. More likely an Oi2 
APPENDIX D

BIOMASS AND BIOMASS ACCUMULATION DATA 
Table 38. Biomass data for each pedon.

\begin{tabular}{|c|c|c|c|c|c|c|c|c|}
\hline Pedon & $\begin{array}{c}\text { Landscape } \\
\text { position }\end{array}$ & Living & Dead & $1-5 " d b h$ & $.1-1 " \mathrm{dbh}$ & Seedlings & Shrubs & total \\
\hline & & & & $---M$ & רa---. & - & ---- & ----- \\
\hline $99-83002$ & $\mathrm{~T} 1$ & 84 & 0 & 27 & 0.00 & 0 & 10 & 111 \\
\hline $99-93006$ & $\mathrm{~T} 2$ & 339 & 0 & 28 & 0 & 0 & 22 & 367 \\
\hline 00-83002 & T3 & no data & & & & & & \\
\hline 99-93002 & $\mathrm{R} 1$ & 315 & 0 & 0 & 0 & 0 & 0 & 315 \\
\hline 00-83001 & $\mathrm{R} 2$ & 169 & 11 & 0 & 0 & 0 & 0 & 180 \\
\hline 00-93001 & R3 & 221 & 3 & 24 & 0.00 & $<1$ & 15 & 248 \\
\hline 00-93003 & R4 & 153 & 1 & 30 & $<1$ & $<1$ & 0 & 185 \\
\hline $99-83001$ & SSC1 & 166 & 0 & 8 & 6 & 0 & 0 & 180 \\
\hline 99-93005 & SSC2 & 311 & 4 & 19 & 1 & $<1$ & 0 & 335 \\
\hline 00-93002 & SSC3 & 198 & 19 & 50 & 1 & $<1$ & 0 & 267 \\
\hline $99-93001$ & SSA1 & 557 & 0 & 4 & 1 & 0 & 0 & 562 \\
\hline 99-93003 & SSA2 & 516 & 0 & 10 & $<1$ & $<1$ & 0 & 526 \\
\hline $99-93004$ & SSA3 & 817 & 24 & 358 & 1 & $<1$ & 0 & 1200 \\
\hline
\end{tabular}


Table 39. Individual sawtimber biomass for each species at each site.

T1: 99-83002

Sawtimber biomass

\begin{tabular}{lr}
\hline Species & Mg/ha \\
\hline Hemlock & 47.3 \\
Red Maple & 11.0 \\
B. Cherry & 2.8 \\
R. Spruce & 23.4
\end{tabular}

T2: $99-93006$

Sawtimber biomass

\begin{tabular}{lr}
\hline Species & Mg/ha \\
\hline Hemlock & 95.6 \\
Red Maple & 9.6 \\
Red Spruce & 20.3 \\
Spruce & 185.6 \\
Y. Birch & 28.4
\end{tabular}

T3: $00-83002$

No Data

R1: 99-93002

Sawtimber biomass

\begin{tabular}{lr}
\hline Species & Mg/ha \\
\hline Beech & 27.4 \\
Birch & 9.2 \\
Cherry & 86.3 \\
Cucumber & 12.4 \\
R. Maple & 179.4
\end{tabular}

R2: 00-83001

Sawtimber biomass

\begin{tabular}{lr}
\hline Species & $\mathrm{Mg} / \mathrm{ha}$ \\
\hline Beech & 6.0 \\
Cherry & 17.2 \\
Red Maple & 107.6 \\
F. Magnolia & 15.8 \\
Y. Birch & 22.0
\end{tabular}

R3: 00-93001

Sawtimber biomass

\begin{tabular}{lr}
\hline Species & Mg/ha \\
\hline Hemlock & 114.8 \\
Cherry & 6.0 \\
Red Maple & 17.3 \\
S. Maple & 5.1 \\
Y. Birch & 60.1 \\
R. Spruce & 17.6
\end{tabular}

R4: 00-93003

Sawtimber biomass

\begin{tabular}{lr}
\hline Species & Mg/ha \\
\hline Hemlock & 61.0 \\
R. Spruce & 77.2 \\
Red Maple & 11.1 \\
Y. Birch & 3.9
\end{tabular}

SSC1: 99-83001

Sawtimber biomass

\begin{tabular}{lr}
\hline Species & Mg/ha \\
\hline Beech & 6.0 \\
Cherry & 17.2 \\
Red Maple & 106.2 \\
Magnolia & 15.8 \\
Y. Birch & 20.5
\end{tabular}

SSC2: 99-93005

Sawtimber biomass

\begin{tabular}{lr}
\hline Species & Mg/ha \\
\hline Beech & 172.6 \\
Cucumber & 24.7 \\
R. Oak & 8.6 \\
Sweet Birch & 11.7 \\
S. Maple & 35.6 \\
Y. Poplar & 58.0
\end{tabular}

SSC3: 00-93003

Sawtimber biomass

Species $\quad \mathrm{Mg} / \mathrm{ha}$

Am. Beech $\quad 48.9$

Cherry

85.8

Red Maple

56.6

Y. Birch

6.2
SSA1: 99-93001

Sawtimber biomass

\begin{tabular}{lr}
\hline Species & Mg/ha \\
\hline Beech & 20.4 \\
Y.Poplar & 38.3 \\
S. Maple & 23.0 \\
Basswood & 85.8 \\
Hickory & 127.1 \\
White Ash $^{1}$ & 26.7 \\
R. Oak &
\end{tabular}

SSA2: 99-93003

Sawtimber biomass

\begin{tabular}{lr}
\hline Species & $\mathrm{Mg} / \mathrm{ha}$ \\
\hline Beech & 28.7
\end{tabular}

B. Birch 2.0

B. Locust $\quad 12.8$

Hemlock $\quad 0.6$

R. Maple $\quad 8.0$

F. Magnolia $\quad 4.7$

Red Oak ${ }^{1}$

S. Beech $\quad 31.5$

S. Birch $\quad 1.8$

Service Berry $\quad 3.1$

S. Maple $\quad 4.0$

Y. Poplar $\quad 93.1$

SSA3: 99-93004

\begin{tabular}{lr}
\hline Species & Mg/ha \\
\hline Beech & 55.7 \\
Chestnut Oak & \\
Locust $^{1}$ & \\
R. Oak & \\
S. Hickory & \\
Sourwood & 19.4 \\
S. Maple & 2.5 \\
R. Maple & 2.6 \\
& 49.4
\end{tabular}

${ }^{1}$ Data for Red and Chestnut Oak were omitted due to the overestimated values that were generated. The regression equation (Eq.5) that was used produced elevated values for large trees $(\mathrm{DBH}$ as great as 37 inches). 
Table 40. Stand ages and biomass accumulation rates for each pedon.

\begin{tabular}{cccc}
\hline Pedon & $\begin{array}{c}\text { Landscape } \\
\text { position }\end{array}$ & Stand age & $\begin{array}{c}\text { Biomass } \\
\text { accumulation rate }\end{array}$ \\
\hline & & yr. & $\mathrm{Mg} \mathrm{ha}^{-1} \mathrm{yr}^{-1}$ \\
$99-83002$ & T1 & 81 & 1.37 \\
$99-93006$ & T2 & 81 & 4.53 \\
$00-83002$ & T3 & 82 & no data \\
$99-93002$ & R1 & 83 & 3.79 \\
$00-83001$ & R2 & 90 & 2.00 \\
$00-93001$ & R3 & 98 & 2.53 \\
$00-93003$ & R4 & 82 & 2.25 \\
$99-83001$ & SSC1 & 81 & 2.22 \\
$99-93005$ & SSC2 & 97 & 3.46 \\
$00-93002$ & SSC3 & 82 & 3.25 \\
\hline
\end{tabular}




\section{APPENDIX E}

\section{CLAY MINERALOGY FOR EACH PEDON}


Table 41. Clay mineralogy for each pedon

\begin{tabular}{lcccccccc}
\hline Pedon & Horizon & LP & Geology & \multicolumn{2}{c}{ Verm Kaolinite Illite } & Lepid & Quartz \\
\hline 99-83002 & Btg1 & T1 & New River & 53 & 20 & 4 & 14 & 10 \\
$99-93006$ & Bt & T2 & Kanawha & 16 & 28 & 8 & 22 & 26 \\
$00-83002$ & Bt1 & T3 & New River & 47 & 35 & A & 8 & 10 \\
& & & & & & & & \\
$99-93002$ & Bw1 & R1 & Kanawha & A & 41 & 18 & 18 & 23 \\
$00-83001$ & Bw1 & R2 & Kanawha & 52 & 19 & 6 & 5 & 19 \\
$00-93001$ & Bt & R3 & Pottsville & A & 35 & 22 & 11 & 29 \\
$00-93003$ & Bh & R4 & Kanawha & 51 & 26 & 6 & 6 & 11 \\
& & & & & & & \\
$99-83001$ & Bw & SSC1 & Kanawha & 25 & 18 & 7 & A & 48 \\
$99-93005$ & Bw1 & SSC2 & Mauch Chunk & 41 & 23 & 10 & A & 27 \\
$00-93002$ & Bw1 & SSC3 & New River & M & 56 & M & 9 & 35 \\
$99-93001$ & Bt1 & SSA1 & Mauch Chunk & 51 & 21 & 8 & A & 20 \\
$99-93003$ & Bt1 & SSA2 & Mauch Chunk & 35 & 26 & 14 & A & 25 \\
$99-93004$ & Bt & SSA3 & Mauch Chunk & 39 & 23 & 8 & A & 30 \\
\hline
\end{tabular}

LP = Landscape position

$\mathrm{T}=$ Terrace

$\mathrm{R}=$ Ridge-top

SSC $=$ Sideslope with cambic horizon

SSA = Sideslope with argillic horizon

$\mathrm{A}=$ Absent (or present in trace amounts)

$\mathrm{M}=$ Mixed layer

Verm. $=$ Vermiculite

Lepid. $=$ Lepidocrocite 